FARM

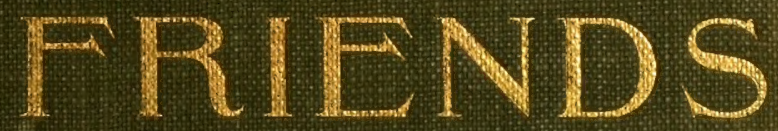

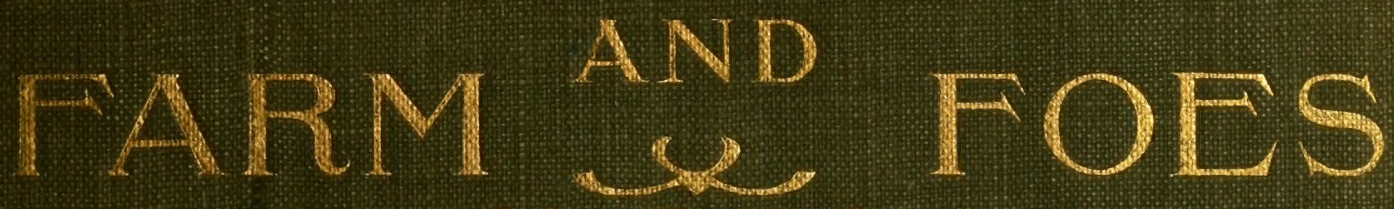
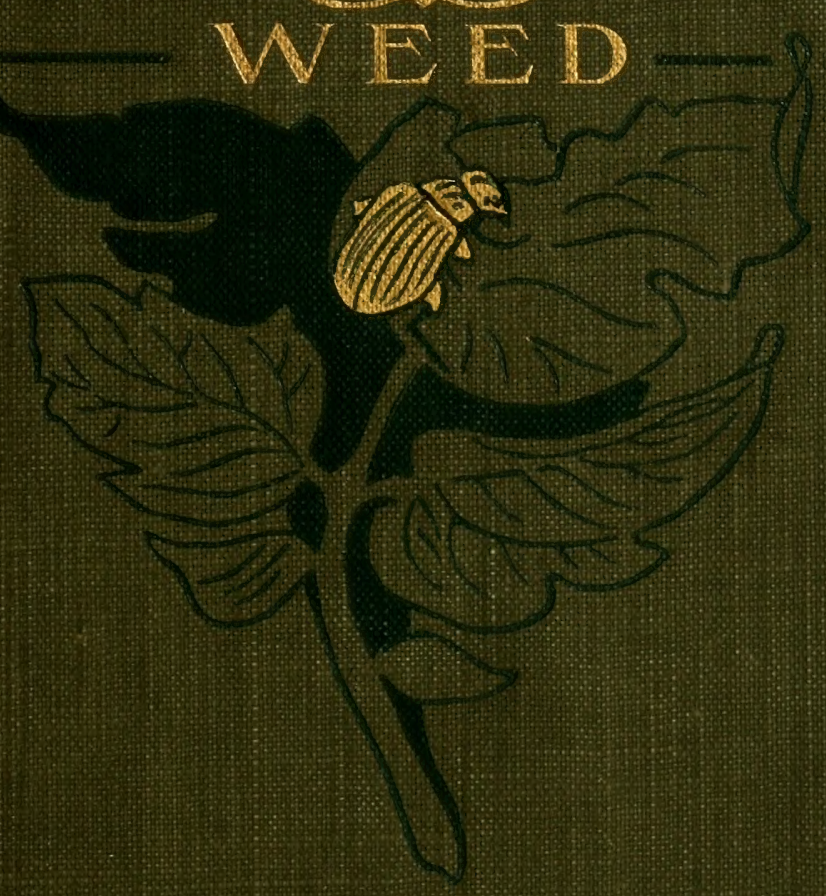


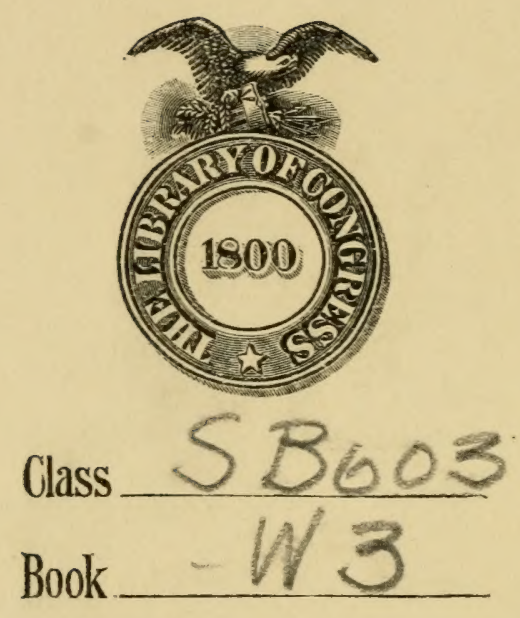

Copyrightt $\mathrm{N}^{0}$.

COPYRIGHT DEPOSIT. 





\section{- FARM FRIENDS AND FARM FOES}

A TEXT-BOOK OF AGRICULTURAL SCIENCE

BY

CLARENCE M. WEED, D.Sc.

STATE NORMAL SCHOOL, LOWELL, MASSACHUSETTS

D. C. HEATH \& CO., PUBLISHERS BOSTON NEW YORK CHICAGO 


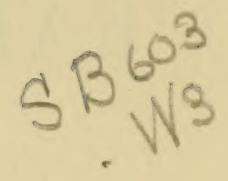

Copyright, i 9 Io,

By D. C. Heath \& Co. 


\section{PREFACE}

THIs book is intended to serve as a text and guide for the study of those plants and animals so vitally related to crop production as often to determine success or failure therein. The information given embodies the latest researches of that host of investigators who have done such great service in the advancement of agriculture in recent years. The text has been so combined with directions for observation and expression that it is hoped that teachers will be able to lead their pupils to a first-hand knowledge of the most important plants, insects, birds, and mammals to be found in the region of the school.

Most of the original engravings are from drawings by Mr. W. I. Beecroft, a few being adapted from the publications of authors to whom credit is given in the list of illustrations. Many of the insect pictures are from woodcuts originally made for the classic report on Insects Injurious to Vegetation, by Dr. T. W. Harris, for the use of which thanks are returned to Mr. J. Lewis Ellsworth, Secretary of the Massachusetts State Board of Agriculture. For courtesies in connection with other illustrations I am indebted to Misses Hazel Dearth, Alice Manning, and I. S. Cragin, and Messrs. James Hall, A. I. Randall, E. D. Sanderson, A. D. Selby, A. H. Verrill, and C. W. Woodworth, as well as to the Experiment Stations of Illinois and New Hampshire and the United States Department of Agriculture. I have also to thänk Mr. W. F. Fiske, of the Gypsy Moth Laboratory, for kindly reading the proof of the chapters on Predaceous and Parasitic Insects.

C. M. W. 


\section{CONTENTS}

\section{PART I}

\section{FRIENDS AND FOES AMONG THE WEEDS}

CHAPTER

I. The Wreds of Roadsides and Waste Places . . . I

II. The Weeds of Meadows and Pastures . . . . I 3

III. The Weeds of Gardens and Cultivated Fields • . 3 I

IV. The Weeds of Grain and Forage Crops . • • . 45

V. The ECONOMics of Weeds • • • • • • . 55

\section{PART II}

\section{FRIENDS AND FOES AMONG THE INSECTS}

VI. Orthoptera: the Grasshoppers, Crickets, and CockROACHES . . . . . . . . . 65

VII. Hemiptera: the True Bugs . . . . . . 73

ViII. The Butterfles and Moths • . . . . . 96

IX. The Two-ivinged Flies • . • • . . . I 22

X. Coleoptera : the Beetles . . . . . . . I3I

XI. Hymenoptera: the Ants, Bees, Wasps, And Saivflies . 149

XII. Insecticides and their Application . • • • . 155

XiII. The Predaceous Insects . . . . . . . . 163

XIV. The Four-winged Parasites . . . . . . I74

XV. The Two-winged Parasites . . . . . . 188

XVi. The Pollination and Fertilization of Flowers • . 194

XVII. The Insect Pollinators . . . . . . . 203

\section{PART III}

\section{FRIENDS AND FOES AMONG THE FUNGI}

XVIII. The Mushrooms, Toadstools, And Molds • . . 215

XIX. The Downy Mildews . . . . . . • . 219

XX. The Smut Fungi . . . . . . . . . . 226

XXI. The RUSTS . . . . . . . . . . 231 
CHAPTER $\quad$ PAGE

XXII. The Ascospore ANd Other Fungi . • • • . 242

XXIII. Bacterial Diseases of Plants. • • • • 229

XXIV. Preventives of Fungous Diseases . • • • 264

XXV. Fungous Diseases of Insects . . . . . . . $27 \mathrm{I}$

XXVI. Bacteria and Plant Food • • • • • 275

\section{PART IV}

\section{FRIENDS AND FOES AMONG THE BIRDS}

XXViI. The Relations of Birds to Fruit Orchards • . 285 XXViil. The Relations of Birds to Meadows and Pastures . 291

XXiX. The Relations of Birds to Gardexs and Fields • 296

\section{PART V}

FRIENDS AND FOES AMIONG THE MAMMALS

XXX. The Squtrels . . . . . . . . . 307

XXXi. The Mice and Rats . . . • • . • • $3^{12}$

XXXiI. The Rabbits, Pocket Gophers, Moles, and Shrews • 321

Bibliography • • • . • . • • • • 328

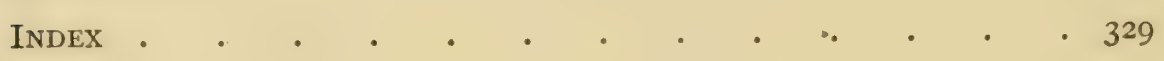




\section{LIST OF ILLUSTRATIONS}

Monarch Butterfly. From Nature Biographies . . . . . xi

Cover Design for Booklet. From a Japanese Stencil . . . . 2

Dandelion Seedheads . . . . . . . . . . . . 5

Burdock . . . . . . . . . . 7

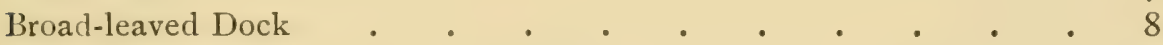

Evening Primrose . • . . . . . . . . . . . Io

Toadflax or Butter-and-Eggs . . . . . . . . • . I I

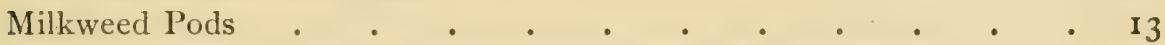

Sprig of Johnson Grass. Redrawn from Cates and Spillman . . I4

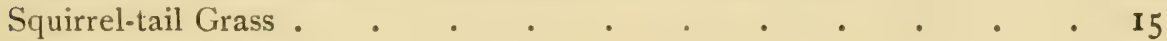

Cone-flower . . . . . . . . . . . . . . . . . 16

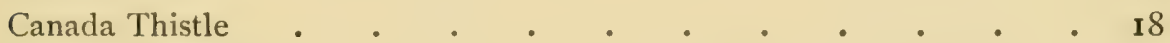

Milkweed Seeds . . . . . . . . . . . 2 I

Sheep Sorrel . . . . . . . . . . . . 22

Hardhack . . . . . . . . . . . . . 24

Poison Hemlock .

Poison Ivy. From Drazving by A. I. Randall . . . . . 27

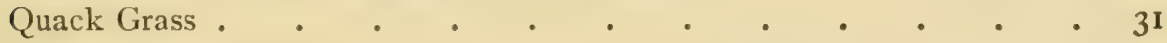

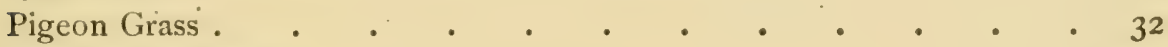

Shepherd's Purse . • . . . . . . . . . 33

White Pigweed . . . . . . . . . . . 35

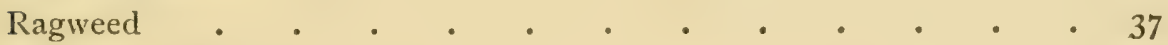

Clotbur . . . . . . . . . . . . . . . . 38

Ground Cherry or Physalis . . . . . . . . . 40

Jimson Weed. . . . . . . . . . . . . 4 . 4

Gill-over-the-Ground . . . . . . . . . . . 44

Mixture of Weed Seeds. From U.S. Department of Agriculture - 46

Meadowsweet . . . . . . . . . . . 55

Spud . . . . . . . . . . . . . . . . . 56

Broad-leaved Dock. Redrazen from Henkel. . . . . . 59

Goldenrod Seedheads • . . . . . . . . . 6I

Cover Design for Booklet on Insects . . . . . . . . 64

Mouth Parts of Grasshopper . . . . . . . . . . 66 
Grasshopper: Nymeh and Adult 。

Grasshopper: Nymph and Adult • • • • • • • 66

Oblong Leaf-winged Grasshopper. From Harris. . • . . 67

Common Cricket. Female. From Harris . . . . . . 68

Tree Crickets : Male and Female. From Harris . . . . . 68

Mole Cricket. From Harris. . . . . . . . . 70

Squash Bug • . . . . . . . . . . . . 73

Chinch Bug. From Harris . . . . . . . . 75

Map showing Distribution of Chinch Bugs. After Webster . . . 76

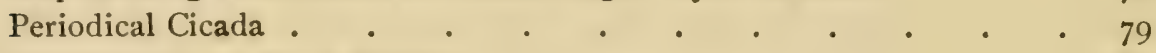

Tree Hoppers. From Harris . . . . . . . . So

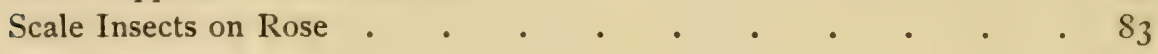

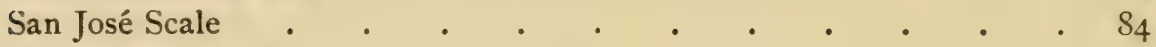

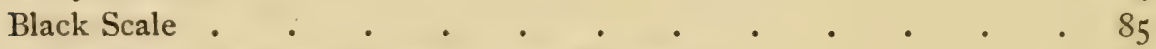

Spring Grain Aphis. Redrawn from Webster . . . . . 88

Eggs of Apple Aphis . • . . . . . . . . . . . 91

Ant attending Aphides . . . . . . . . . . . . . . 92

Elm Leaf affected by Aphides . . . . . . . . . 93

Cicada emerging from Nymph Skin. Photograph by A. H. Verrill - 95

Promethea Moth Cocoon . . . . . . . . . 96

Orange-dog Caterpillars. Photograph by A.H. Verrill. . . . 98

Butterfly of Orange-dog Caterpillar. Photograph by A. H. Verrill . 99

Luna Moth . . . . . . . . . . . . 102

Tent Caterpillar . . . . . . . . . . . . . I03

Gypsy Moth . . . . . . . . . . . . I04

Army Worm . . . . . . . . . . . . . 108

Cutworm Larva. From Harris . . . . . . . . IIo

Cotton Bollworm. Photograph by A. H. Verrill . . . . . I I

Codling Moth . . . . . . . . . . . . II 3

Apples showing Calyx Open and Calyx Closed _ . . . . . I I4

Leaf Roller Moth. From Harris . . . . . . . II5

Peach-twig Borer. After Clarke . . . . . . . . II7

Tineid Moth . . . . . . . . . . . II 8

Winter Nest of Brown-tail Moth . . . . . . . . I2I

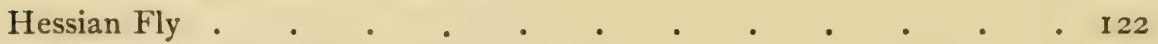

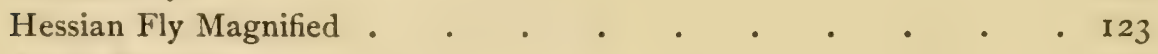

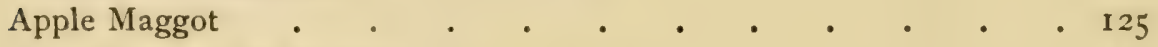

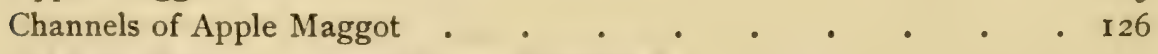

Cabbage Maggot. Adapted from Washburn . . . . . 127

White Grub or May Beetle . . . . . . . . . I3I

Lamellicorn Beetle. From Harris . . . . . . . 132

Potato injured by White Grub . . . . . . . $~ . ~ I 32$ 
Rose Chafer. From Harris.

PAGE

Eyed Elater. From Harris .

133

Leaf Beetle. From Harris .

I34

Colorado Potato Beetle .

I 35

Flea Beetle

Round-headed Apple-tree Borer. From Harris .

Plum Curculio

Strawberry Weevil. Redrawn from Riley

Peach injured by Curculio

Mexican Cotton Boll Weevil .

Infested Cotton Square .

Cherry Sawfly

Willow Sawfly Larva

Head of Aphis. Redrawn from Slingerland

Bucket Pump

A Simple Spraying Outfit. Redrawn from Marlatt

Powder Gun .

Tiger Beetles. From Harris

Ground Beetles. From Harris

Tiger Beetle Larva. From Harris

Ladybird Beetle and Pupa. From Harris

Blister Beetle. From Harris

Soldier-bug

Robber Fly. From Harris

Syrphus Fly

White-faced Hornet. From Packard

Dragon-fly

Egg Mass of Mantis

Dragon-fly. From Harris

Ichneumon Fly ovipositing in Cocoon

Long-tailed Ichneumon Fly. From Harris .

Ichneumon Fly and Chrysalis. Photog; aphy by A. H. Verrill

135

- 139

- 140

142

- 142

I 43

I 44

- 145

149

- 150

- 155

- 156

- 158

- $16 \mathbf{I}$

- 163

- 164

- 165

- 165

- 166

I 66

- 168

- 169

- 170

- 171

I7I

173

- 174

- $\mathbf{1 7 5}$

Ichneumon Flies. From Harris . • . . . • • 177

Cocoons of Microgaster Flies, From Harris . . . . . 177

Caterpillar with Cocoons of Parasites . . . . . . . I78

Parasite of Grain Aphis. Redrazen from Washburn . . . . 179

Chalcid Parasite of Gypsy Moth's Eggs. After Howard . . . 184

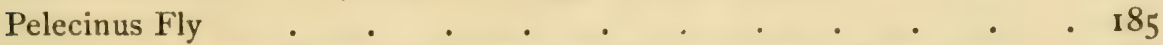

Tachinid of Army Worm. Drazun from Photograph by Slingerland . 188

Tachinid Parasite of Gypsy Moth. After Fiske . . . . . 190

Cherry Blossoms . • • • • • • • • • • 194 
Structure of Cherry Blossom . PAGE

Pollination and Fertilization 195

Cucumber Fluwers. After Drawings by James Hall

Strawberry Blossoms

Pear Blossoms

Leg of Bumblebee .

Bumblebee. Photograph by A. H. Verrill

Easter Lily

Pear Leaf Blight. Redrawn from Galloway.

Mushroom

Mushroom Spawn. Drazen from Photograph by Atkinson

Mycelium of Mold. Redrawn from Zopf

A Dying Mushroom

Potato Leaf affected with Late Blight. Afler Galloway

Corn Smut. Drazun from Photograph by Selby . . . . . 228

Spore Germinating: seen from Above. Redrawn from R. E. Smith . 232 Spore Germinating: seen from Side. Redrawn from R. E. Smith . 232 Black Knot on IVild Cherry . . . . . . . . . 243 Apple Scab . . • . . . . . . . . . 245 Apples dwarfed by Scab. Redrawn from Chester. . . . . 246 Apples affected by Bitter Rot. From Scott, U.S. Department of Agriculture.

Brown Rot Spores Developing . . . . . . . . 248

Brown Rot Spores Germinating . . . . . . . . 248

Potato Leaf affected by Early Blight. After Galloway . • . . 255 Bee's Claw with Blight Bacteria. After Whetzel and Stewart . . 260 Fly with Fungus . . . . . . . . . . . 273

Soy Bean Root showing Tubercles. From Hopkins • • • . 277

Red Clover: Effect of Bacteria. Drazin from Photograph by Hopkins . 279 The White-throated Sparrow. After Biological Survey . • . 284 Tent Caterpillar Nest attacked by Birds . . . . . . 287 May Beetle. From Harris . . . . . . . . . 29I Click Beetles. From Harris . . . . . . . . 292 Meadow Grasshopper. From Harris . . . . . . . 293 Screech Owl. Photograph from Life . . . . . . . 294 Prairie Dog Burrow: Sectional View. After Merriam . . . 306 Field or Meadow Mouse. After Samuels . . . . . . 312 Wild Morning-glory Roots. Drawn from Photograph by Lantz . . 314 


\section{LIST OF ILLUSTRATIONS}

PAGE

Hyacinth Bulbs eaten by Pine Mice. Photograph from Lantz • . 315 White-footed or Deer Mouse. After Samuels . . . . . 318 Cornstalk ruined by Brown Rats. Photograph from Lantz . . . 319 Rat Trap used in Burma. After Lantz . . . . . . . 319 Barrel Trap for Rats. After Lantz . . . . . . . 320 Wellhouse Rabbit Trap. After Lantz . . . . . . 323 Georgia Gopher. After Biological Survey . • • • • 324

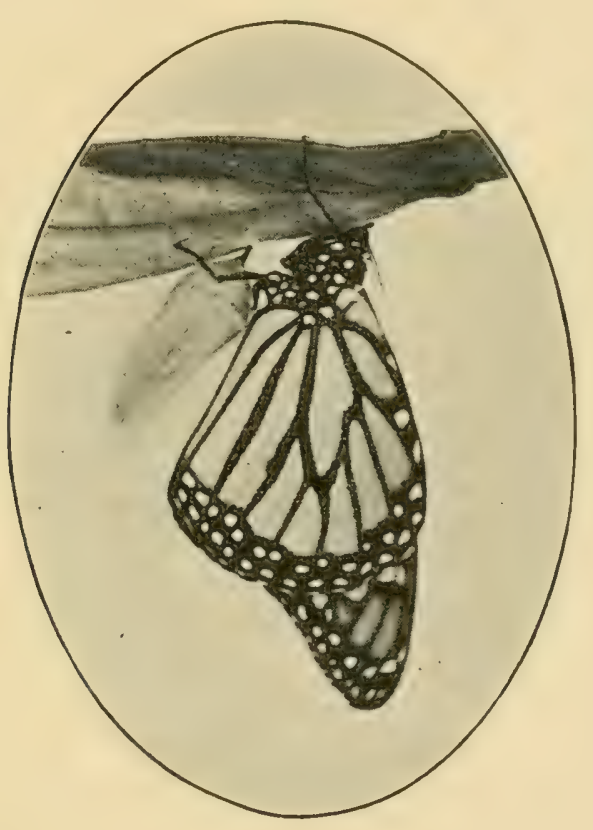



PART I

FRIENDS AND FOES AMONG THE WEEDS 


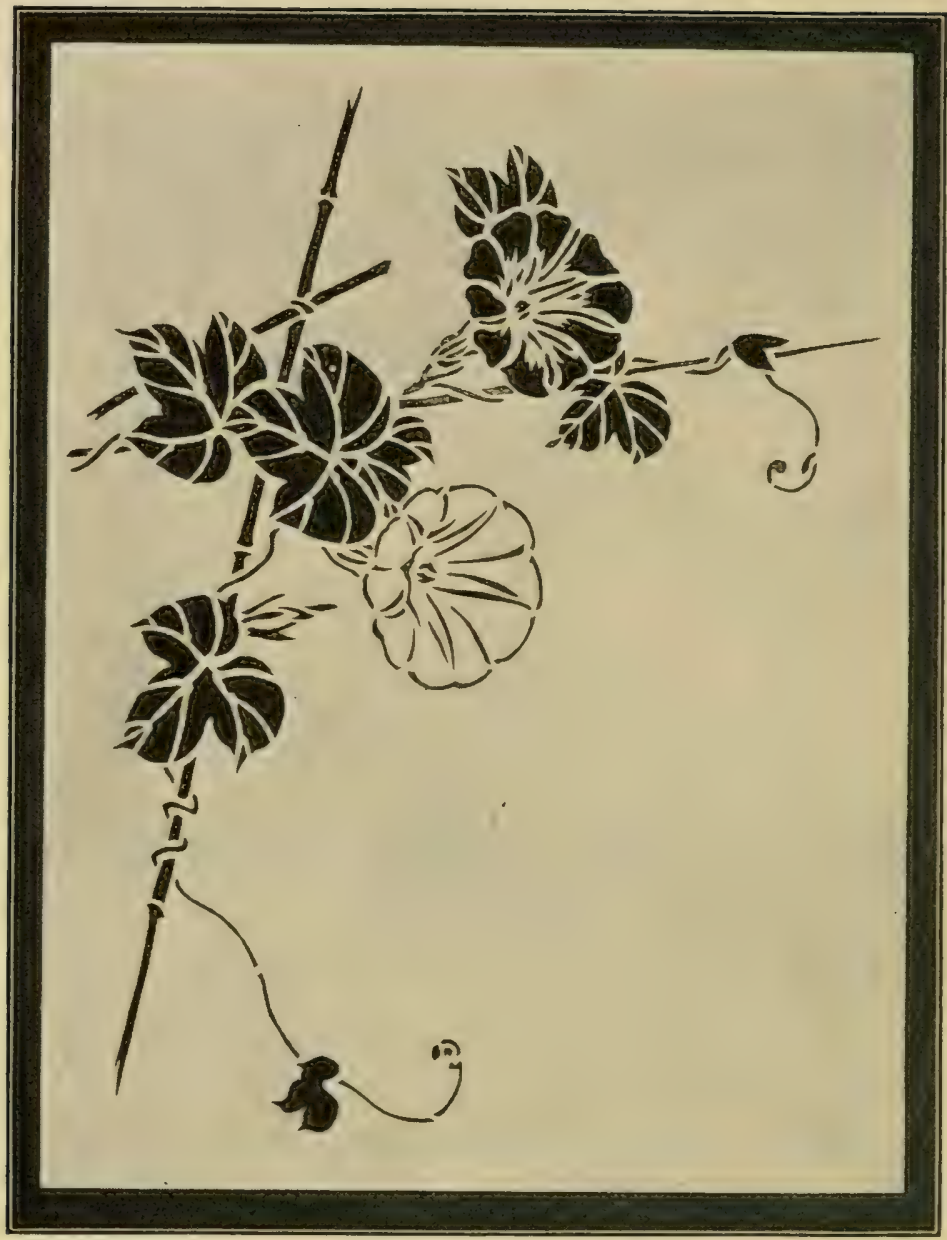

Cover DEsign For A Booklet oN WEEDS

THE BOOKLET ON WEEDS

Every pupil should make a booklet for each of the important subjects taken up for study. The booklet should be composed of such drawings and language work as is done in connection with the study as well as mounted leaves or other specimens that are readily included in it.

The ordinary plain paper used for drawings serves very well. A good size is six by nine inches. Three holes should be punched near one end for binding with raffia in a cover of thicker paper.

It is very easy to get material for the booklet on weeds. Characteristic leaves, branches, and flowers may be pressed and mounted. Young seedlings also may be preserved. 


\section{FARM FRIENDS AND FARM FOES}

\section{CHAPTER I \\ The Weeds of Roadsides and Waste Places}

ONE of the commonest sources of the seeding of cultivated lands is from the weeds that grow in such abundance along roadsides and on neglected ground. A great variety of weedy plants are to be found in these situations, and very often the weeds that first infest tillable fields come from the seeds of these plants. Consequently our study of weeds may well begin with these wayside plants.

When a plant is common and widely distributed, one is pretty certain to find that it is splendidly equipped for the battle of life. The Dandelion is a good example of such a plant. The root is thick and tough and leathery, running straight down into the ground with branches toward the bottom. It is filled with a milky juice and is intensely bitter to the taste. The thickened root enables the plant to store up food one season for the sending up of blossoms the next. The tough and leathery structure enables it to bear trampling by cattle without injury. The bitter taste and milky juice protect it from being eaten by insects or higher animals.

The stem between the root and the leaves is so short that there is practically none at all. This also saves the plant from injury when it is trodden under foot. The 
leaves are spread out in a rosette; the lower ones are the longest; the margins are deeply cut; they are bitter and filled with a milky juice. The rosette habit, the longer lower leaves, and the incised margins all help the plant to get the most benefit possible from the sunlight; while the bitter taste and milky juice render the leaves unfit for animal food.

The Dandelion flowers are borne on hollow cylindrical stalks filled with a similar bitter juice and covered with a woolly coating. By means of the hollow cylinder the greatest strength is obtained in proportion to the amount of material used, while the woolly coating makes the ascent of ants and other wingless creatures difficult. Several rows of green straplike bracts surround the flower head, forming what the botanists call the involucre. With the help of these bracts the flowers close at night and in rainy weather. This saves the pollen from being washed away by the rain, and probably helps the plant by preventing radiation of heat. A large number of little flowers are crowded together to make up what we call the blossom, thus rendering it so conspicuous that it is freely visited by bees, which carry the pollen from flower to flower and thus bring about cross-pollination.

When the little ovules have been fertilized by pollen, the Dandelion closes up for a time in order to ripen its seeds. Then the flower stem lengthens rapidly, generally carrying the closed head above the surrounding grass. When the seed ripens, the bracts open and the round "blowball" appears, ready for the wind to carry the seedlike akenes away.

It is not strange that a plant with these advantages should become a weed, crowding out others, and claiming all the space and light and moisture wherever a few Dande- 
lions become established. To a greater or less extent, practically all the other weeds have similar advantages, and one of the interesting things about the study of each is to find out what these advantages are. This will often point the way to the best means of checking the increase of the plant.

The Dandelion also illustrates another general truth, namely, that the way in which we think of a plant depends upon our point of view. To farmers and to the owners of lawns, the Dandelion is a weedy pest, fit only to be exterminated. To gardeners, it is a profitable crop plant, worthy to be carefully cultivated. To physicians, it is a storehouse of remedies for human ills. To bota-

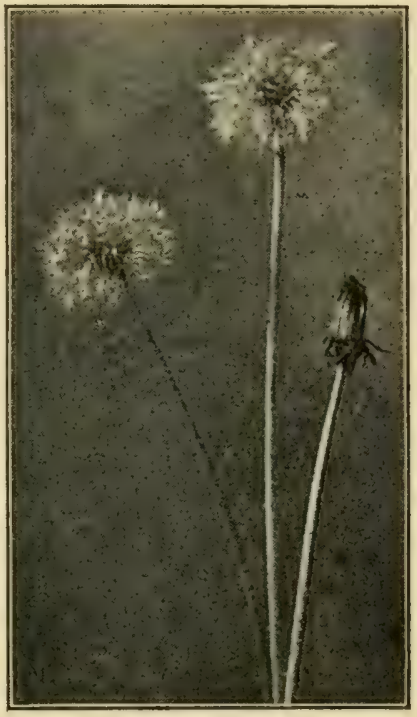

DANDELIONS nists, it is a species of great interest because of its adaptations to the conditions of plant life. To artists and poets and many other lovers of nature, it is of inestimable value in decorating the landscape and lighting up the fields with its wonderful disks of gold.

\section{Sunflower Family}

The Dandelion is a typical example of the great group of plants called the Sunflower family, or Compositæ. The principal character of this group is the association of many tiny florets in a flower head. A large proportion of our weeds belong to this family, the members of which have many advantages in the struggle for existence.

The various adaptations for the dispersal of the seeds are among the important advantages of the composite plants. 
The seedlike fruits of some are furnished with a fringe or tuft of hairs that enables them to becarried long distances by the wind. The dandelions, thistles, goldenrods, and asters are examples of these. Many others are provided with some device for becoming attached to animals. Burdocks, clotburs and Spanish needles are examples of these. Still others have hard nutlike fruits that are able to float upon running water. The tall ragweeds and the common ragweeds are examples of these.

It is easy to understand why the roadsides are generally infested with many of the composite plants whose seedlike fruits or akenes are blown about by the wind. The open road furnishes free passage, and the fences along its borders catch hosts of them as they fly along. So the goldenrods, asters, thistles, and various sorts of wild lettuce are familiar roadside weeds. These are mostly native species that are willing to live and let live, and thus do not entirely overrun the ground as do such imported pests as Prickly Lettuce, a roadside weed which has attracted much attention during recent years. It apparently was first noticed in New England about I868, and it is now found over a large part of the United States, being especially abundant in the Middle West.

Prickly Lettuce, when mature, is from two to six feet high, with a straight stalk bearing large stemless leaves, the bases of which clasp the main stalk. The flowers are borne in an open panicle on the upper end of the stalk, each blossom being small, yellow, and not very conspicuous. The first flowers appear about midsummer, and others continue to develop until autumn. The leaves and stems have a milky juice which is doubtless a protection from insect attack, while the numerous prickles over the surface are likewise a pro- 
tection from the attack of herbivorous animals. Many thousand seeds are commonly produced by a single plant, and each of these seeds is furnished with a fine pappus, so that it may be carried long distances by the wind.

This is a difficult weed to keep in check. It occupies roadsides and waste grounds very quickly, and its seeds are blown from such situations to cultivated fields. The growing of hoed crops and repeated mowing of patches where the plant is established - thus preventing seeding are the most advisable measures of protection.

Among the composite plants whose seeds are carried by animals, the Burdock is perhaps the most generally known. Its coarse leaves and spiny seed heads are to be found in many neglected corners. It is a biennial, making a vigorous growth of leaves near the ground during the first season, and storing in

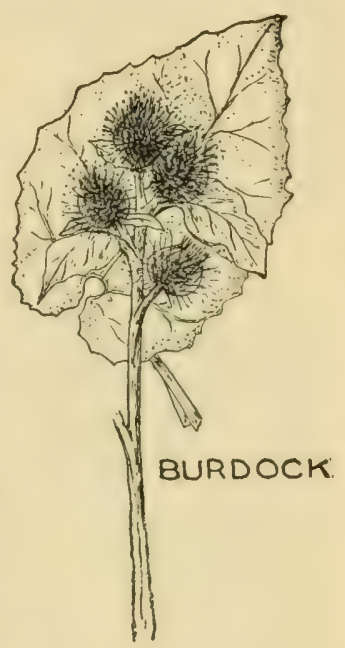
the root a large amount of nourishment for the rapid development of the great flower stalk the second season. The tiny florets are crowded together in composite heads, having a pinkish color, and surrounded by a mass of bracts with recurved spiny tips. As the seeds ripen, these spiny burs become brown and easily break away to be carried by any animals that may come in contact with them, scattering the seed as they journey. The plants vary greatly in height according to the richness of the soil in which they grow. They are easily pulled up when quite small, but the second season they must be repeatedly cut off below the soil surface to prevent their blossoming, or else killed by pouring kerosene or some other suitable liquid upon the crown. 


\section{Buckwheat and Plantain Families}

The most familiar members of the Buckwheat family are the sorrels, docks, and smartweeds. These all have small flowers and the triangular akenes characteristic of the family.

Two species of Dock are abundant and widely distributed weeds. These are the Curled Dock, Sour Dock, or

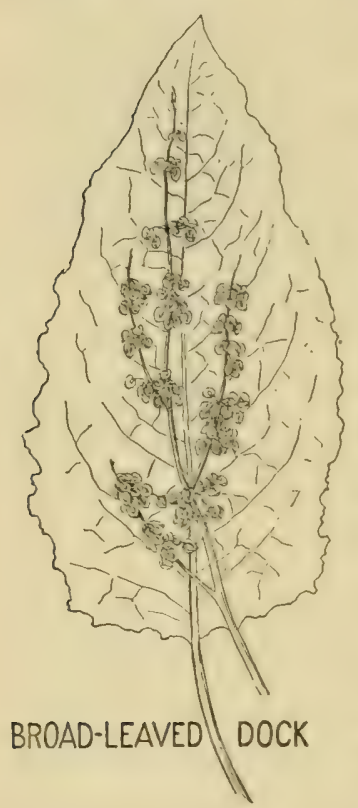
Yellow Dock, and the Bitter Dock or Broad-leaved Dock. The former is easily distinguished by its comparatively narrow curled leaves. The Curled Dock is often used for "greens," but the Broad-leaved Dock is so bitter that it is not used for this purpose. Both of these species are likely to be troublesome in wet places especially along the roadsides and fences, and can be eradicated only by extermination of the roots. These contain so much stored-up nutriment, that if the plants are simply pulled up and left upon the surface of the ground, the seeds often mature; consequently it is better to burn the plants or at least to cut the stalk away from the roots.

On account of the way in which the Broad-leaved Plantain springs up wherever civilized man appears, the American Indians used to call it White Man's Foot. It is the most abundant representative of the Plantain family, though in fields of grain and forage crops the Narrow-leaved Plantain is more troublesome.

The Broad-leaved Plantain is a sturdy, vigorous plant, well adapted to crowding out others in the struggle for 
existence. Its roots are large and fibrous, taking firm hold upon the soil; the main stem is so short as not to appear above the ground; the broad flat leaves are borne on the ends of long stems, forming a rosette on the soil surface, so that the trampling of animals does not injure them. The leaves are not palatable to higher animals and are eaten by very few insects.

In addition to these advantages the small inconspicuous flowers are borne closely along the sides of the strong and flexible stalks, upon which the seeds rapidly develop. The seeds themselves are provided with a mucilaginous covering, which when wet adheres to the fur of animals so that they are likely to be carried in many directions.

The Plantain is especially likely to take possession of waste corners of the premises, as well as neglected places along roadsides. In lawns it is a vexatious pest, requiring constant attention to keep it out. The use of a sharppointed hoe which will cut off the plant below the surface is an effective remedy. During wet weather, the smaller seedlings may readily be pulled up by hand.

\section{Weeds of Other Families}

Three common wayside weeds belong to the Evening Primrose family - Fireweed or Willow-herb, Evening Primrose, and Sundrops. The first named often springs up where a fire has left a lot of ashes for the seeds to sprout in. It is seldom really troublesome in cultivated land, although its winged seeds must be scattered everywhere.

The Evening Primrose is one of the most abundant roadside plants. It is especially likely to take possession of sloping banks and thrives either in open sunlight or in partial shade. Under favorable conditions it grows to a 
height of several feet and produces in its curious capsules vast numbers of the tiny seeds, which may be blown long

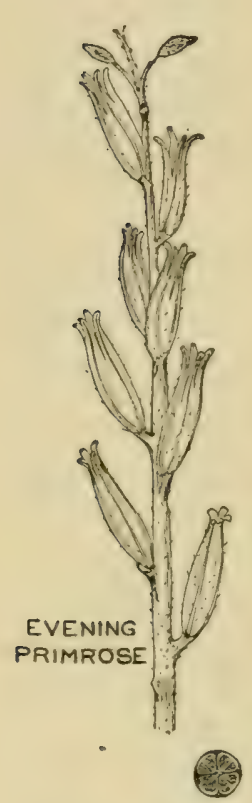
distances by violent winds. It may be successfully kept in check by repeated mowings close to the ground.

The little plant called Sundrops seems like the Evening Primrose in miniature. It is often abundant along roadsides, and frequently spreads to adjacent fields, where it is especially troublesome in broadcasted grain and forage crops. Thorough tillage in corn, cabbage, or some other hoed crop is the best way to rid a field of it.

A great variety of other plants are likely to appear as more or less noxious weeds along roadsides. Familiar examples in many of the states are found in Teasel, Elecampane, and Butter-and-Eggs. Each of these may occasionally become troublesome in cultivated fields if left unmolested along the roadsides, but they are comparatively easy to keep in check by attention at the proper season.

Some common roadside weeds have escaped from cultivation. The majority of these are likely to be plants formerly grown in flower gardens, although most of them are now displaced by more attractive flowers. Throughout New England, the pinkish blossoms of Bouncing Bet, or Soapwort, are likely to be seen along the roadside near an abandoned homestead. In early times this plant evidently was a garden favorite and it remains along the roadside, though it seldom becomes really troublesome as a weed.

In a similar way, the curious Cypress Spurge, the Day Lily, and the Live-forever are commonly seen along the 
roadsides, to which they have escaped from gardens. They are usually present in solid patches, which are to be cleared away only by thorough digging of all the roots. As a rule these are not likely to go so far afield or prove so troublesome as certain of the aromatic herbs that were formerly cultivated. Of the latter Yarrow, Tansy, and Caraway are commonly most injurious. The seeds of these may be scattered by the wind over considerable areas. Consequently it is very desirable that the small plants be destroyed as soon as possible.

Even some of the plants in the vegetable garden may at times escape from cultivation and become troublesome. The most notable illustrations of this are found in Horse-radish, Chicory, and Salsify or Vegetable Oyster. The first named reproduces only by vegetative roots ; but Chicory and Salsify produce seeds that scatter in all directions, coming up as weeds in situations favorable to growth.

Not all of the plants, however, which are likely to take

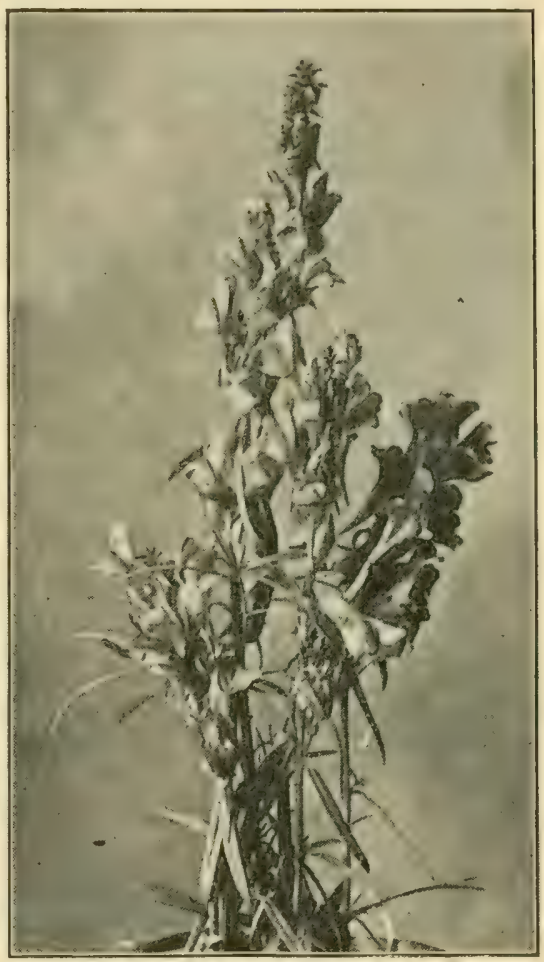

TOADFLAX OR BUTTER-AND-EGGS possession of neglected bits of ground are to be classed as wholly noxious. For example the Sweet Clovers are among the most abundant occupants of such soil, crowding out other plants and developing a thrifty growth of leaves and blossoms. The blossoms are a valuable source of 
nectar for honey bees, and the roots of these clovers improve the condition of the soil by adding to its store of nitrogen and organic matter. It is doubtful whether in the case of many bits of waste land occupied by these plants it is worth while to attempt to exterminate them. When they grow along alfalfa or other fields in which they are harmful, however, they should of course be destroyed.

\section{OBSERVATIONS FOR PUPILS}

1. Make a list of twelve common roadside weeds in your locality.

2. Make drawings of as many of these as you can to use in your Booklet on Weeds. For this booklet print an attractive title-page. Perhaps the one on p. 29 will help you in doing this.

3. Press and mount some of the leaves and flowers of the roadside weeds to bind up in your booklet.

4. Make a list with this heading at the top of the page :

Roadside Weeds I have seen in Neighboring Fields

5. Find out how the seeds of roadside weeds are scattered. Make lists with these headings :

Seeds scattered by the Wind

Seeds scattered by Water

Seeds scattered by Animals

6. Always watch for new roadsicle weeds. When one appears, send a specimen to your State Experiment Station to learn its name. Here is the sort of a letter you should send:

\section{$\longrightarrow$, KanSAS,}

September 2I, I9II.

EXPERIMENT STATION, Manhattan, Kansas.

Gentlemen : I am sending you by this mail in a package securely packed a plant I found by the roadside near our school. We do not know its name and we shall be greatly obliged if you will inform me what it is and whether it is likely to become a troublesome weed.

Sincerely yours,

JAmes A. Smith. 


\section{CHAPTER II}

\section{The Weeds of Meadows and Pastures}

THE weeds of meadows and pastures that have been in sod for many years are likely to be native species that appear to be trying to bring the fields back to the original condition of the untilled land. In a forest region, the land will revert to forest; in a plains region, it will revert to plains. This is the natural result of neglect on the part of the farmer; nature is claiming her own.

The ways in which these fields are brought back to the wild condition are well worth studying. Go to such a neglected pasture and notice how shrubs and vines spring up along the sides of fences, where seeds have been blown by winds or left by birds. Notice how these spread outward by means of seeds and rootstocks. See how the untilled, unfertilized sod is "run out," and re-

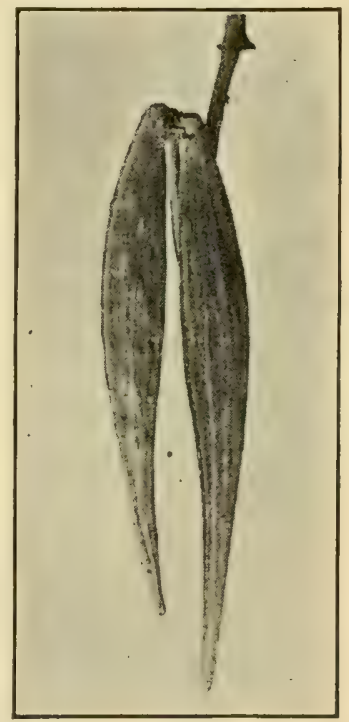

MILKWEED PODS placed by mosses or ferns or other weedy growths, and how the seeds of Hardhack, Sweet-fern, and other plants begin to grow in the moss. Then see how these low bushes form a suitable shelter for poplars, birches, and other trees to start, and how these in turn may shade the ground for the early growth of larger trees.

In the plains regions the plants will be different, but the 
process of encroachment from the neighboring species will be much the same. In pastures where the native grasses form the chief forage, a frequent cause of weed invasion is found in keeping too many animals in the fields. These feed so closely that the grasses are killed out, and other plants not eaten by the stock take their places.

On the other hand, many meadows have problems of their own. This is most likely to result from a mixture of the seeds of some weed with that of the grass, clover, or grain, or it may be through the seeds in the fertilizers from the barn. Sometimes these may be weeds new to the locality, and it is then very important to exterminate them before they scatter seed.

\section{Troublesome Grasses}

A number of grasses more or less valuable for forage often prove difficult to eradicate in meadows and pastures where they crowd out more valuable sorts. They are able to displace other plants because they spread by creeping underground rootstocks that take complete possession

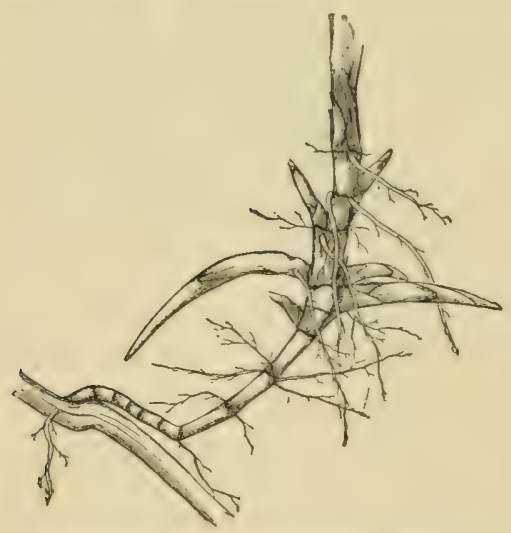

SPRIG OF JOHNSON-GRASS of the soil in all directions. One of the worst of these is the notorious Witch-grass, Quackgrass, or Couch-grass. In localities where Johnson-grass has been introduced for forage, this is likely to prove as troublesome. Wire-grass or Flat-stemmed Blue-grass is another species that is likely to take possession of light sandy soil.

All these troublesome grasses are likely to be introduced, either with barnyard fertilizers or with grass and grain 
seeds. In permanent pastures some patches may be kept down by salting, thus inducing close feeding by sheep or cattle. In some cases, however, the removal of the turf or cultivation with a hoed crop becomes necessary.

Most meadow and pasture weeds are troublesome, because they reduce the product of the land, but the Squirreltail Grass or Tickle-grass is much worse than these, because it produces festering sores in the mouths of cattle. Consequently it not only reduces the grass and hay crop, but it renders them of less value for feeding. This is a widely distributed annual, easily recognized by its glistening, whitish heads of barbed awns, each awn an inch or two in length. It is especially troublesome in Western meadows and alfalfa fields, being considered in many regions the most pestiferous weed. The seeds are carried by the wind, though fortunately they are not distributed in grass seed. Rotation with an annual crop, or the pulling and burning of the plants before the heads appear are the only effective remedies, and they necessitate community action for the best results. If one farmer keeps his meadows free and his neighbor does not, there is little benefit to either.

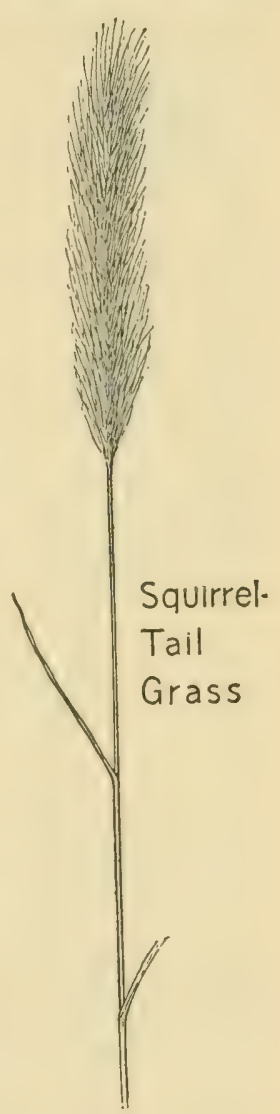

In California a closely related annual grass from Europe is troublesome in similar ways. It is called Mouse Barley or Wild Barley, and is often abundant in sandy pastures. 


\section{Sunflower Family}

Meadows and pastures that have been seeded for a long time are liable to become infested by a number of vigorous weeds of the great Sunflower or Thistle family (Composite), some of which prove exceedingly troublesome unless they are carefully eradicated on their first appearance. One of

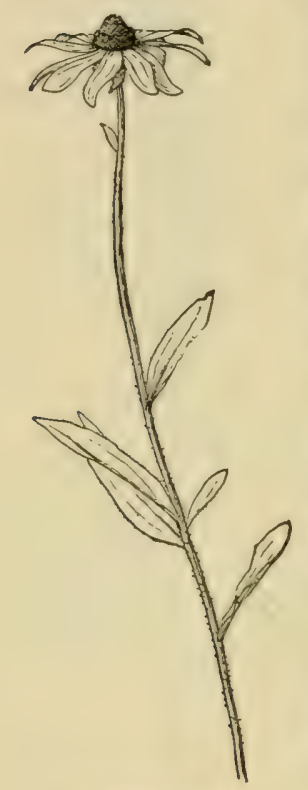

CONE-FLOWER

the most conspicuous of these is the Oxeye Daisy or Whiteweed. In many of the New England and Middle states whole fields are whitened by it in early summer. The blossoms are beautiful, but their beauty is not likely to be appreciated by the farmer who sees them take the place of a good crop of hay. The plant is so distinctive on account of the character of the blossoms, with their large yellow centers surrounded by rays of long white petals, that it is at once recognized by every one. The flowers are borne on stems one to two feet high, several of the stems generally developing from a single root.

It is easy to see why the Oxeye Daisy is a dangerous intruder in meadow lands. Its period of blossoming extends from May to November, so that it is able to ripen an enormous number of seeds. These are readily scattered and soon develop into little plants that are rarely noticed the first season. They blossom quickly the second season, and continue as perennials thereafter. Each plant spreads out to form new crowns, and thus crowds out the surrounding grasses. The fresh leaves, stems, and flowers are distasteful to cattle, and very few insects will eat any part of the plant. 
The careful pulling of these daisies in meadows or pastures when they first appear and before they have gone to seed, will help greatly in keeping them out. In general, frequent rotation of crops with good cultivation and fertilization is useful in preventing the growth of this as well as of other weeds.

The Orange Hawkweed is another dangerous weed of this family introduced from Europe. Although the date of its appearance on American soil is comparatively recent, it has spread over a large part of the country, and in many places has already become seriously troublesome. It has a dozen or more medium-sized orange-colored blossoms borne on the top of a hairy stem, a foot or more high. Nearly all the oblong leaves are in a rosette at the base of the flower stalk; they are hairy and about four inches long. The plant lives from year to year by means of its rootstocks and runners that spread from a single root in all directions.

The Orange Hawkweed is most likely to appear in pastures or ineadow lands, and should be destroyed by a thick layer of salt as soon as noticed. When large areas are infested, the application of salt at the rate of a ton to the acre is recommended.

The spiny leaves, stems, and purple flower heads of the common Pasture Thistle are familiar to every one. This plant is a biennial. When one of the winged seeds lodges in a bit of soil, it develops the first season into a rosette of leaves that store up nutriment in the thickened taproot. This rosette lives through the winter and the next season sends up the spiny flower stalk to develop a new crop of seeds. Fortunately the plant spreads only through the seeds and is easily destroyed by cutting off below the crown. 
The Canada Thistle is distinguished from the common pasture thistle by its small flower heads. The plant, as a whole, is more slender, while its leaves are narrower and more deeply cut. The flowers are purple,

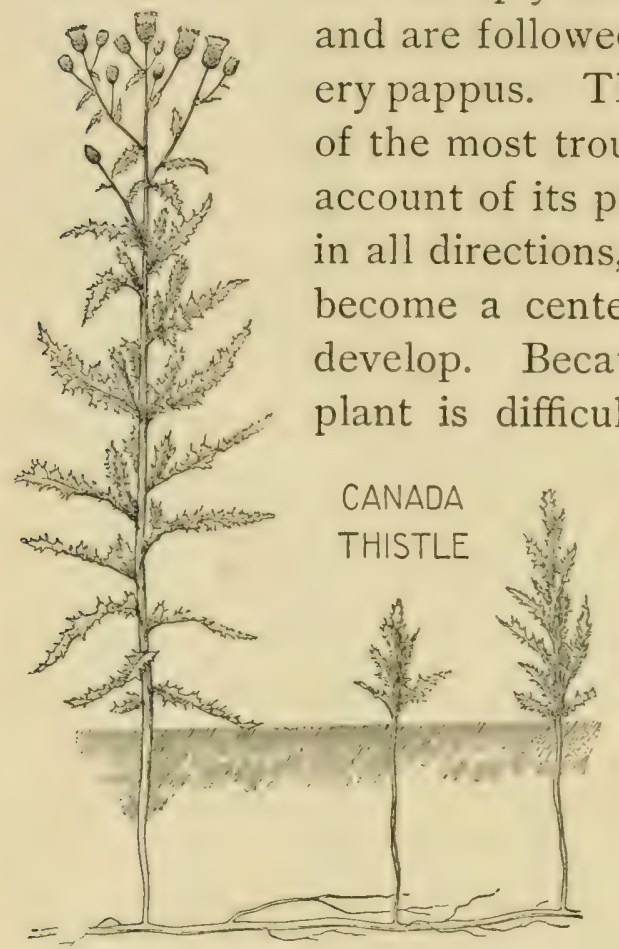
Th seeds bearing a feathery pappus. The species is regarded as one of the most troublesome weeds, largely on account of its perennial roots which spread in all directions, so that a single plant may become a center from which many others develop. Because of these roots, also, the plant is difficult to eradicate. Thorough plowing, repeated mowing, seeding down to get a heavy sod, and the application of kerosene to the roots are the remedies most generally recommended.

When tillable land is badly infested with Canada Thistles the following procedure is recommended by the Illinois Experiment Station:-

I. Cut the thistles when in full bloom (July) as close to the ground as possible.

2. Plow about three inches deep and sow millet or Hungarian grass, seeding heavily; harrow. This may follow the preceding at once or after some two weeks' delay.

3. In September plow under the crop, or save it for hay, as desired. At all events, plow and seed liberally with rye. 
4. Plow under rye in May and seed again with millet, or Hungarian grass, or plant to some hoed crop (corn) and give the most thorough cultivation, with continued destruction of every remaining thistle.

5. Continue the clean cultivation and sharp lookout for thistles another year.

The Cone-flower, the Flea-banes or White-tops and the various sorts of Wild Sunflowers are well-known plants that are frequently troublesome in meadows and pastures. They generally make a tall and vigorous growth that shades the grass beneath, and thus prevents its development. When they take possession, tillage and reseeding are necessary.

The Chondrilla, a curious European plant comparatively recently introduced, proves troublesome in pastures with light soils. It is a biennial, developing during the first season low-lying rosettes of leaves, very similar to those of the dandelion. On these the small yellow composite flowers appear, to develop later into seed fruits, which also are strikingly like those of the dandelion. They are scattered by the wind, so that when once introduced into a new locality the Chondrilla is likely soon to be generally distributed. Cultivation and fertilization seem to be the best measures to exterminate it.

Several trouble makers in lowland pastures are those weedy composite plants having spiny or hooked fruits that become attached to the wool of sheep or the hair of other animals. The Spanish Needles, Bur Marigolds, Beggar Ticks, and Stick-tights are examples of these. Such plants are likely to develop in undrained areas, and proper drainage is generally necessary to check their increase. Along 
the margins of streams frequent mowing through the season will prove helpful.

The Blue and the White Vervains or Wild Verbenas, Ironweed, Joe-pye weed, and the various Wild Asters are other well-known plants of this family that are likely to be abundant in moist places in pastures and meadows. Drainage, tillage, and seeding down are the best ways to be rid of them.

\section{CARrot FAMily}

The Wild Carrot, which is typical of the great family of umbel-bearing plants, is particularly troublesome in pastures and meadows. Such fields are often wholly occupied by it, rendering the little grass that may develop practically worthless. This plant has been troublesome in the Eastern states for many years, and has recently been spreading through the fertile fields of the Middle West.

The small white flowers of the Wild Carrot are crowded together in flat conspicuous heads, commonly having a little purple flower in the middle. These develop into curious masses, suggesting miniature birds' nests, rounded in outline. The individual "seeds" are really spinose akenes which may be distributed by animals or by the wind that blows the whole seed head along when it breaks off.

The Wild Carrot propagates only by means of seeds, so that the main point to be attained in suppressing it is the prevention of seeding. This may be accomplished by persistent mowing, which will finally lead to the death of the plants. At first, mowing simply causes new flower-bearing shoots to be sent out. The plants may also be destroyed by hand pulling, or by cutting them off slightly below the soil surface with a spud, hoe, or disk harrow. When a grass field is badly infested with this weed, the 
best way of treating it generally is to plow and plant with cultivated crops for a time.

In the states bordering on the Gulf of Mexico another species of Wild Carrot is very troublesome. It is called the Small Carrot. It is a biennial, occurring in all sorts of situations to which the seeds may be carried by wind or animals.

\section{Other Herbaceous Weeds}

'Two members of the Plantain family are often troublesome in meadows and pastures. The Western or Largebracted Plantain appears to have been originally native to the Mississippi Valley, but has recently become very generally distributed in grass and clover seed. It is commonly classed as a winter annual, though it may also develop from seeds scattered in spring. It differs from the other plantains in its plume-like flower heads, due to a large bract projecting from beneath each

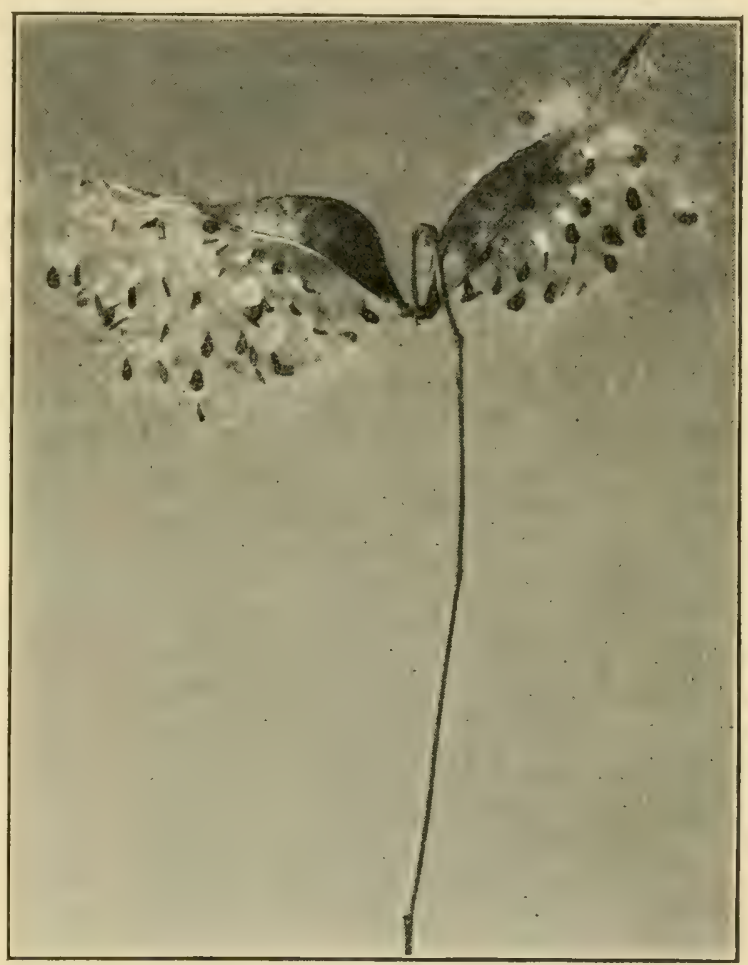

Milkiveed SeEdS tiny floret on the spike. The leaves are short and narrow so that the plants do not become conspicuous until the 
flower heads appear. A single plant may produce three thousand seeds which are likely to be carried but a short distance. Consequently a dense colony will soon be present, crowding out all other vegetation. Pulling the plants, frequent mowing, or tillage in a hoed crop seem to be the only remedial methods. The sowing of pure grass and clover seed is the most important preventive measure.

The Ribwort, Rib-grass, or Narrow-leaved Plantain is one of the most trying pests that infest light soils. It is commonly introduced in clover and grass seed and soon develops a thickened rootstock that renders it very difficult to eradicate. On account of this rootstock it is a perennial, so that the mere prevention of seeding will not lead to extermination; the roots must be pulled up, cut off

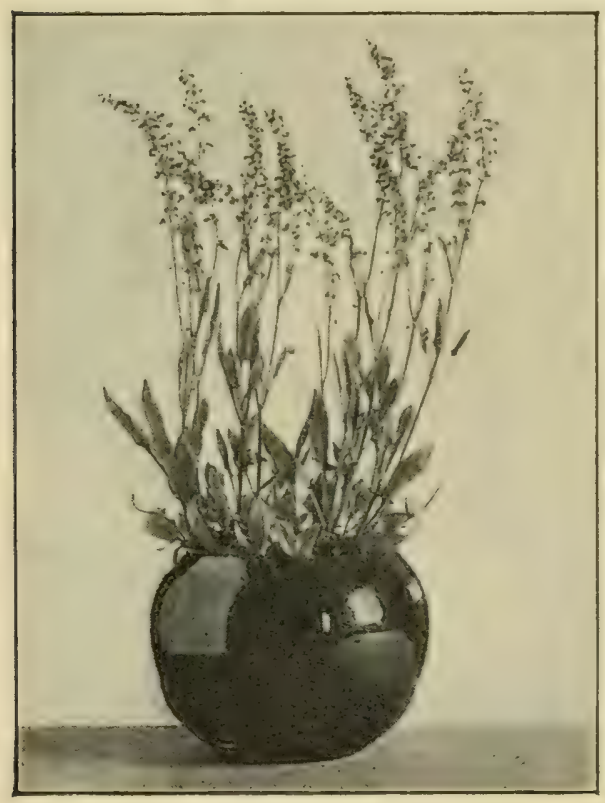

SHEEP SORREL

spot where the soil is acid. by good methods of farming deeply, or plowed under.

On barren sandy lands in meadows and pastures as well as in cultivated fields, the Sheep Sorrel or Field Sorrel is likely to take complete possession of the soil. This well-known weed is an indication of poor farming, and the best way to eradicate it is to enrich and till the infested areas. Its seed is very commonly distributed in barnyard fertilizers, as well as in other ways, and the plant is likely to appear in any neglected It is so easily eradicated that it need never become 
troublesome. Its presence indicates that lime should be applied.

Another group of plants that are likely to run out the grass in light soils in dry situations is that of the Fivefingers or Cinquefoils of the great Rose family. The Common Cinquefoil, the Silvery Cinquefoil, and the Norwegian Cinquefoil are the most abundant species. The Barren Strawberry is closely associated with these in structure and habit of growth, and is often found in the same situations. The Cinquefoils have compound leaves composed of five leaflets, while the leaves of the Barren Strawberry are composed of but three leaflets. Like the common Wild Strawberry all these plants occupy increasing areas by sending out runners just above the surface of the ground, the runners starting new plants that take root and in turn send out other runners. In this way the soil is soon covered with a mat of plants that prevents the growth of grasses.

These low-growing weedy plants often furnish favorable conditions of shade and moisture for the starting of larger species like the St. Johnsworts and the Goldenrods. There are various kinds of each of these, some of which often render hilly pastures yellow with their bloom. Along with them are likely to occur the white blossoms of the Yarrow and the small flower heads of the Wild Asters.

The presence of most of these weeds in light soils is an indication of the need of soil improvement by tillage and fertilization.

Various kinds of Milkweeds, especially the Common Milkweed, are likely to prove troublesome in pastures and meadows. Such plants send out underground rootstocks in all directions; from these, vigorous new shoots come up so that a strong colony is soon spreading outward to shade 
and destroy the grass. The winged seeds are scattered everywhere; consequently it is very desirable to exterminate wayside plants.

Several species of Buttercups abound in lowland meadows and pastures. When green some of the more abundant of these have an acrid taste that leads cattle to pass them by, though this bitterness is so lost in drying that the hay is not especially injured.

\section{Ferns out of Place}

In the more northern regions of our land various species of ferns often take possession of parts of meadows and

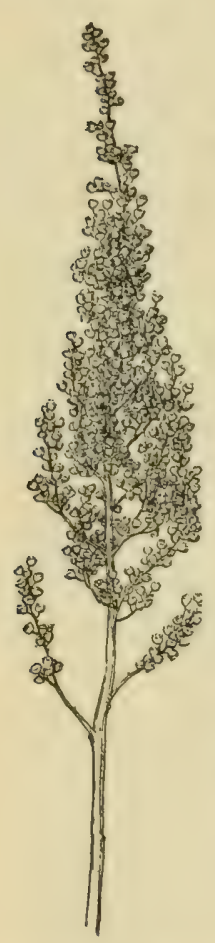
pastures. They are likely to start along a hedge, fence, or the borders of the woods, and gradually to extend over a greater area. The Brake Fern, or Bracken, is one of the most abundant of these. It is especially liable to overrun comparatively dry land in the open HARDHACK sunshine, while most of the other ferns are more likely to overrun moist or shaded parts of a field. The Sensitive Fern, the Cinnamon Fern, and the Flowering or Interrupted Fern are often troublesome in undrained spots. All these ferns, however, are symptoms of lack of drainage or neglect of tillage, and are to be subdued by improved agricultural methods. Their destruction when they have full possession of the soil is a difficult matter, requiring frequent hoeing and cultivating for several seasons. 


\section{Troublesome Trees and Shrubs}

Over a great central region in the United States the Sassafras is a troublesome fence-side bush. Its seeds are carried by birds, and its underground rootstocks spread out to form a thicket of new plants. In the latter respect, it resembles the Yellow or Black Locust, though the seeds of this tree are scattered by the wind. When Locust thickets are once established in a pasture or meadow, they are difficult to eradicate. Their presence, however, is not so dangerous as that of the Honey Locust, for the great thorns of this tree sometimes penetrate the feet of cattle and cause much trouble.

Many other trees and shrubs are liable to prove troublesome in pastures and meadows if permitted to establish themselves along walls and fences. The surest way to prevent their spreading is to cut them off as fast as they appear, cutting persistently every year, especially in summer when the new growth is finished. It is, of course, desirable to do away with all needless fences.

Many kinds of shrubs and trees are likely to take possession of neglected pastures, especially in hilly regions. In northern localities the Gray Birch and the Aspen Poplar spring up in great abundance, as do also the Low Juniper and the Red Cedar or Savin. The latter are especially likely to arise in clumps of Sweet-fern or Hardhack. These are two of the most troublesome pasture shrubs. The easiest way to keep a permanent pasture free from such intruders is to exterminate them as fast as they appear, before they have obtained a firm foothold.

\section{Poisonous Pasture Weeds}

The most vexatious meadow and pasture weeds are those that not only prevent the growth of grasses, but are 
poisonous to stock when eaten. Several such pests have proved very troublesome in the United States, especially in the West, although they are by no means restricted to any one region.

The Loco Weeds are the most notorious of the stockpoisoning herbs; they are so-called because the affected animals become "locoed," the Spanish word for crazy. Several species are known, all belonging to the genus Astragalus, of the great family of Legumes or pod-bearing plants. Peas, beans, and vetches are familiar examples of the legume family. Two species of Loco Weeds are the most important: one is called the Woolly Loco Weed; the other the Stemless Loco Weed. Both are sometimes called Crazy Weed.

The Woolly Loco Weed is a perennial plant having a

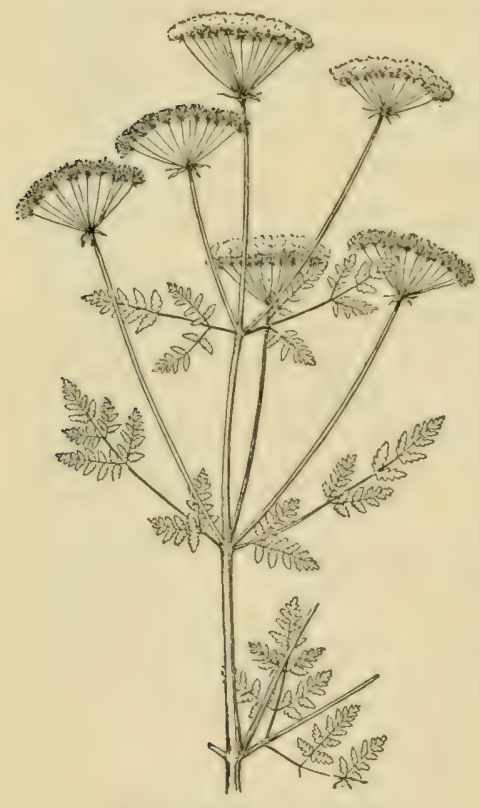

POISON HEMLOCK general resemblance to a Vetch or Larkspur. Its leaves and stems are covered with silky hairs that give it a silvery effect, and its purple flowers develop into two-celled seed-pods. Leafstalks and flower stalks arise from a short central stem. The plant belongs originally to a wide area in the Great Plains region, between Wyoming and Texas, though especially troublesome in Colorado, Nebraska, and Kansas. In Colorado, it was so destructive that bounties were offered for its destruction. In four years nearly $\$ 200,000$ was paid by the state for this purpose.

The Stemless Loco Weed has a more slender appearance 
than the Woolly species. Its leaflets are more slender and its pods are one-celled. It is distributed over an even greater area than the Woolly Loco Weed.

The Larkspurs are closely related to the Loco Weeds, belonging to the same family of Legumes. There are many species of these, several of which are known to be poisonous to stock. The Dwarf Larkspur, the Purple Larkspur, and the Wyoming Larkspur are the most troublesome kinds. They are especially likely to be eaten in early spring, when the leaves offer tempting forage to cattle, before the better plants are well started.

Another weed that has been very troublesome in poisoning stock is the Rattlebox or Rattleweed. This is native to a great region extending from New Jersey to Kansas and Minnesota, occurring especially in low sandy soils. It is dangerous to horses and cattle, both in the pastures and in hay. In some of the Western states disease in horses caused by it is called the Bottom Disease, because only stock pasturing on the so-called bottom lands are likely to be affected by it.

A few poisonous weeds commonly occur in wet places in meadows and pastures. Thus the well-known Sneezeweed with its attractive yellow flowers is poisonous to cattle, sheep, and horses. It is abundant along ditches and the borders of ponds and streams. The Poison Hemlock or Spotted Cowbane, which occurs in similar situations, is even more dangerous. Not only are all parts of the plant extremely poisonous to man and animals, but water in which the roots have been trampled may prove poisonous. The roots have an aromatic taste that leads children to eat them, sometimes with fatal results. Both these plants should be exterminated wherever they occur.

In the case of all these poisonous weeds the only safety 
lies in exterminating them to as great an extent as possible. And it is especially important that there be coöperation to this end among all the landowners of a locality.

\section{Poisonous Trees and Shrubs}

The Choke Cherry is one of the commonest and most dangerous of shrubs. It is found along roadsides, woods and fences, throughout the greater part of Canada and the

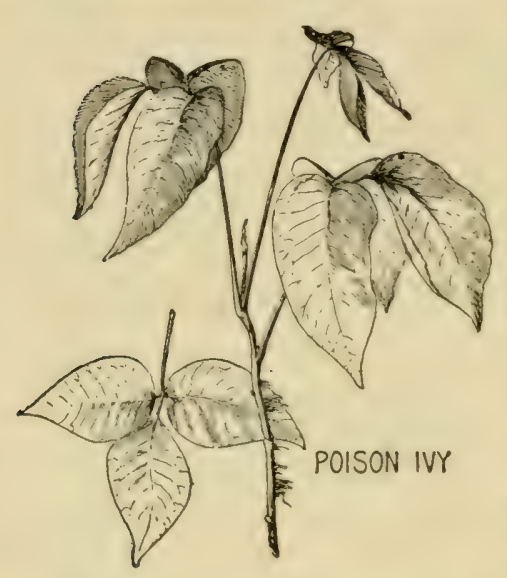
United States. Its seeds are scattered everywhere by birds, and it spreads rapidly by underground stems. As the leaves wilt after the bushes are cut, Prussic acid, a virulent poison, is formed within them by the combination of two nonpoisonous substances. This is often fatal to cattle that feed upon the withering branches. Consequently it is desirable to prevent the growth of Choke Cherry bushes, and to leave no freshly cut leaf-bearing branches within the reach of stock.

Black Cherry leaves also develop this poison as they wither, and perhaps the same is true of other wild cherries.

Certain species of Laurel, especially the Mountain Laurel and Sheep Laurel or Lamb-kill, are poisonous to stock. The leaves and green stems contain a principle that is even more fatal than strychnine.

Among the more important shrubs that are likely to spread from walls and fences into the adjacent fields are the various species of Sumachs. The seeds of these are left along fences by birds, and the resulting plants, when 
well grown, send out rootstocks in all directions. From these rootstocks other plants arise, so that a continually expanding thicket of shrubbery is soon established. The Smooth, the Dwarf or Mountain, and the Staghorn or Velvet Sumachs, are the common nonpoisonous species. The Poison Ivy and the Poison Sumach or Poison Dogwood are the poisonous species. The Poison Ivy is one of the most generally distributed. These, however, are harmful chiefly to mankind and are external irritants rather than internal poisons.

\section{A LITTLE BOOK \\ $\mathrm{OF}$ \\ PROFITLESS WEEDS \\ BY}

CHARLES R. JONES

Tough thistle choked the fields and killed the corn, And an unthrifty crop of weeds was borne.

$$
\text { -DRYDEn. }
$$

IL.LUSTRATED

THE BROWN SCHOOL

I910

A Suggestion for Title-page of Booklet on Weeds 


\section{OBSERVATIONS FOR PUPILS}

\section{Pasture Weeds}

I. Make a list of twelve weedy plants that you have seen growing in the pastures of your locality.

2. Are such plants more troublesome along fences, hediges, or walls, than in the open pasture?

3. Are weeds more abundant in pastures heavily stocked with domestic animals or those lightly stocked?

4. What are the best ways of getting rid of pasture weeds in your vicinity?

5. If a weedy pasture is near, make a list of the weeds present and mention the way in which each kind probably got started in that field.

6. How often are pastures plowed up and reseeded in your locality?

\section{MEADOW WEEDS}

I. Make a list of the ten most troublesome weeds present in the meadows of your locality.

2. See if you can tell which ones were probably started by being mixed with grass, grain, or clover seed; which were blown in by the wind; and which were brought in in other ways.

3. Are any of these plants that have been recently introduced into your region?

4. If a meadow is near, make a list of the weeds present and mention the way in which each kind probably got started in that field.

5. How often are meadows plowed up and reseeded in your locality ?

6. Which meadows show the most weeds, those recently seeded down or those that have been seeded down for a long time?

READ such references in the following as your teacher directs :

Some Poisonous Plants of the Northern Stock Ranges, Farmers' Bulletin 206. Thirty Poisonous Plants, Farmers' Bulletin 86. Johnson-grass, Farners' Bulletin 279. Canada Thistle, Circular 27, Division of Botany, U. S. Dept. Agr. 


\section{CHAPTER III}

\section{The Weeds of Gardens and Cultivated Fields}

THE weeds that infest gardens and cultivated fields are familiar to most people. Such plants are seen daily by every one in town and country, and must be constantly kept in mind by all farmers and gardeners. To a large extent they are annuals and produce seed in such abundance that neglected soil is quickly covered with young plants. Most of them are easily kept in check when the ground is given proper tillage.

\section{Grass Family}

By far the most troublesome of these garden weeds is the Quack-grass or Witch-grass, which is known by a dozen other names. This notorious pest multiplies both by seeds and by underground rootstocks that penetrate the soil in all directions, sending up leafy branches everywhere. If these rootstocks are cut into pieces, each piece will produce a new plant. On this account, hoeing and cultivating ground infested by Witch-

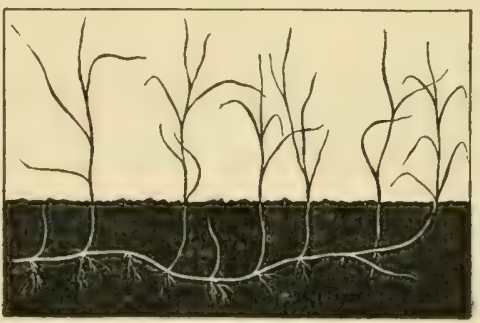

OUACK GRASS grass is likely to do more harm than good. When the grass has taken complete possession of a piece of land, it is often cut for hay, but this only leads to the wider scattering of the seeds through the fertilizers from the barn.

Quack-grass thrives upon ordinary tillage, and is to be subdued only by a vigorous and persistent course of treat- 
ment. It is often said that to kill it, you must dig it out, dry it on a rock, burn it, and then be very careful where you put the ashes! In gardens and limited areas, the best way is to dig out the rootstocks, when no crop is in the ground, with a tined potato digger and cart them away.

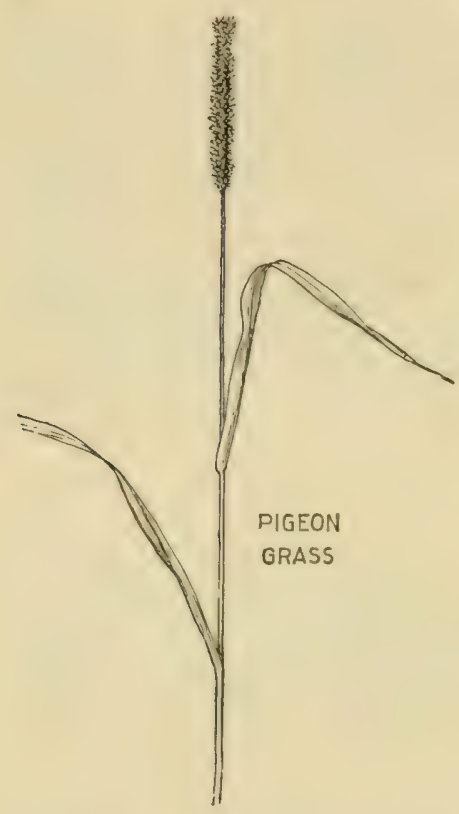
By keeping persistently at the roots every spring and fall, the land can finally be cleared. Small patches may also be smothered by covering the surface with boards, tarred roofing paper, or something similar.

Several species of annual grasses are likely to become troublesome in gardens and fields during the latter part of the growing season. One of these is the curious Flyaway-grass or Old-witch-grass, the plume-like seed heads of which are to be seen every autumn rolling before the wind, and finally lodging along fences. Because of these heads that thus fly along the surface of the ground, dropping their seeds as they go, this grass is likely to appear even in ground that has been kept free from seeding plants. Consequently it is desirable that the grass be kept in check wherever it appears.

Two species of Foxtail or Pigeon-grass are universal weeds. The Yellow Foxtail or Common Pigeon-grass seems to be generally more abundant than the Green Foxtail or Bottle-grass. They are very similar, except for the difference in color. Both appear about midsummer in gardens, cultivated fields, and waste places, often carpet- 
ing the ground with their spiked heads. When mowed off, they send up new heads, which are able to develop close to the soil surface. The seeds of the Foxtails are commonly distributed in clover and millet seed, and so are often sown with these. Persistent late culture and hand weeding are the only efficient means of checking these grasses.

One or more kinds of Crab-grass or Finger-grass are very likely to develop after midsummer, especially in wet seasons or on moist land. These have the peculiarity of spreading their stems in all directions, the stems striking roots into the soil whenever in close contact with it. This makes the plant difficult to eradicate, because any of the rooted stems left will continue to grow.

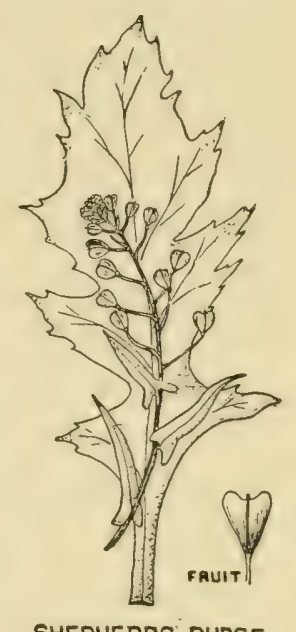

SHEPHERDS PURSE Fortunately it is an annual and so does not retain possession from season to season. It is likely to develop in neglected barnyards and thus have the seeds scattered with the fertilizers.

The seeds of the Barnyard Grass are also very likely to be scattered in the way just mentioned. This is a tall coarse plant, often reaching a height of three or four feet. It frequently develops in corn and potato fields late in summer, getting its growth after cultivation ceases. It is comparatively easy to subdue by hand pulling. Under the name Japanese Millet it has lately been added to the list of desirable forage plants.

\section{Mustard Family}

Several abundant garden weeds belong to the Mustard family. Wild Mustard or Charlock, Black Mustard, Wild Radish, and Peppergrass are familiar illustrations. These 
are all found in gardens more or less, though the Mustards are more likely to be troublesome to grain and forage crops.

The Shepherd's Purse is one of the garden weeds most likely to develop early in the season. It is able to do this because it is a winter annual, developing the autumn before into a rosette of low-lying leaves. In spring it sends up its slender central stalk, along the lower and middle parts of which are a few narrow leaves, some having curiously incised margins, while along the upper part are the small white flowers, crowded together toward the top. These develop into the purse-shaped seed pods, borne on the ends of slender stems.

This familiar plant is commonly found wherever a few inches of waste ground give it an opportunity to grow. Tillage late in autumn or early in spring is the best way to destroy it.

\section{Pink Family}

One or more species of Chickweed are so widely distributed that they occur in almost every garden. The Smooth Chickweed is known by its smooth leaves and stems, and its minute white flowers with the green pistils longer than the petals. It is a winter annual. The Mouse-ear Chickweed is known by its hairy leaves. Technically there are two species known by the latter name; one of these is a perennial.

These Chickweeds multiply by spreading over the surface of the soil as well as by seeds which are produced in abundance throughout the season. They are comparatively easy to keep in check by proper tillage.

During the latter part of summer, the heart of the careless gardener is often vexed by the rapid growth of the 
succulent Purslane or "pusley." Its thick brown stalks creep along the ground, spreading rapidly from the root, and seriously interfering with crop growth. The leaves, as well as the stems, are smooth and thick, while the pale yellow flowers borne in the axils of the leaves generally open only in the morning, when the sun is shining. The small seeds are produced in capsules, the tops of which come off when the seeds ripen. It has been estimated that I,250,000 seeds are sometimes produced by a single plant. Fortunately this Purslane is an annual, requiring only frequent surface tillage for its prevention, although when the plants become large, it is necessary to remove them to prevent their growing again. This is one of those weeds that compel the gardener to keep a soil mulch through the summer, and thus conserve the moisture during the driest season of the year.

\section{Goosefoot and Amaranth Families}

The plant commonly called Lamb's Quarters, Goosefoot, or White Pigweed, is a widespread and troublesome garden pest. Where it finds room, it becomes a large and vigorous weed, five or six feet high and about two feet in diameter. Usually it is two or three feet high. The leaves are somewhat arrow-shaped, with irregular teeth along the margins, and rather long, slender petioles. The narrow clusters of greenish white flowers appear in the axils of the leaves, toward the ends of the

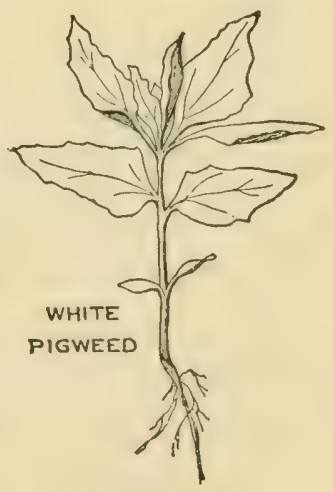
branches. The general color of the plant is pale green, with a whitish powder scattered over the flowers and young growth, and often over the leaves, also. The small seeds are black and shiny when separated from their greenish 
covering. They are developed in great numbers, and often produce plants so crowded together in field and garden that there is no chance for the regular crop to mature.

This White Pigweed often grows rapidly, and should be destroyed by surface tillage. If it gets started in the garden, frequent cultivation is the best way to keep it in check.

The common Pigweed is one of the plants most characteristic of neglected gardens in the latter part of summer. The broad, wavy-margined leaves are borne on the ends of long petioles that arise from a cylindrical main stalk, which in turn grows from a red root. The plant is sometimes known as Redroot. It is an annual, developing rather late in the season, and consequently is very likely to be found in fields of corn and potatoes after cultivation ceases. Each plant produces great numbers of small seeds, some of which may ripen as early as August. The pest is to be attacked by thorough cultivation, or by hand pulling in fields where late tillage is impracticable.

As far as its flowers and seeds are concerned, the Tumbleweed is closely related to the Pigweed, both belonging to the Amaranth family; but in its manner of growth it is very different. The Tumbleweed sends out numerous branches, that give it a broad expanse, so that when the main stalk breaks off near the root, it is able to roll and tumble along the ground with every gust of wind, scattering its seeds as it goes. It commonly brings up beside a fence or other obstruction, where regular windrows of the plants may sometimes be seen. It is easily kept in check in gardens and cultivated fields by tillage or hand pulling. 


\section{Sunflower Family}

The Ragweed or Roman Wormwood is a pestiferous plant found in most situations where weeds may grow late in summer. It is nearly always to be seen along paths and highways, in fence corners, and along garden borders, as well as in cornfields and wheat stubble. It is an annual, and has a straight central stalk from which many spreading branches arise. The latter bear numerous leaves with deeply cut lobes and many small, greenish, inconspicuous flowers. As in the case of the Horseweed, to which the Ragweed is closely related, the pollen-bearing blossoms are borne along the sides of the branches near the tips, while the seed-bearing flowers are borne along the lower parts of the

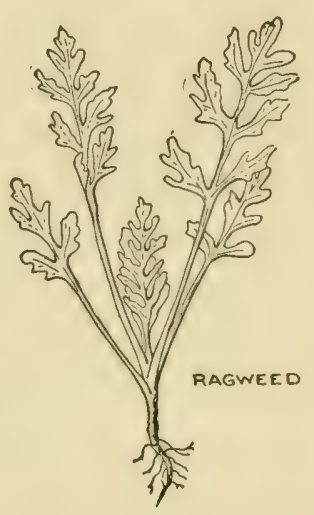
same branches. One reason the Ragweed is so ubiquitous is because the young plants are able to develop in hard soil where most weeds cannot get a foothold.

When mowed off an inch or two above the ground, the Ragweed is likely to produce new branches from the cut main stalk, from which seeds may develop; consequently thorough work is necessary in subduing the pest. One effective method is to pasture infested fields with sheep:

In the Middle West, the Giant Ragweed or Horseweed is one of the most abundant plants. Its luxuriant growth is to be found everywhere, but it is especially vigorous and troublesome on moist bottom lands. Poorly cultivated or untilled parts of such fields are frequently covered with a dense growth of this robust annual, the seeds of which are carried by water from one valley to another. It often 
reaches a height of ten or twelve feet, the simple stems shooting straight upward and bearing along their ribbed sides the large opposite three-lobed leaves with dentate margins. The flowers are small and inconspicuous, being borne in rows along the ends of the branches. The staminate or pollen-bearing blossoms are above the pistillate or seedbearing flowers. The former are much more abundant than the latter. Each of the pistillate flowers bears a single seed. As the Horseweed is an annual, it may be kept in check by thorough cultivation, or in untilled lands by repeated mowings. There is often danger, however, that during times of floods, botton lands may be reseeded from regions upstream.

The Clotbur or Cocklebur is another pernicious weed of the Sunflower family, which commonly develops late in the season in gardens and cultivated fields. This plant is easily known on account of the peculiar burs, or seed heads, covered with hooked spines. It is a low-growing annual,

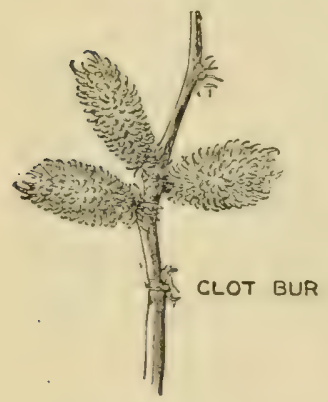
attaining a height of but a foot or two, but spreading over quite an area. The principal stalks are tough and woody, and bear the broad triangular leaves on the ends of long, slender petioles. Two sorts of flowers are borne by each plant, staminate or pollen-bearing, which appear at the upper end of the principal stalk, and pistillate or seed-bearing, which develop lower upon the same stalk. The pollen drops from the former upon the latter, or is blown from plant to plant by the wind, and thus fertilizes the embryo seeds.

The bur really consists of a lot of bracts called, when thus grown together, the involucre. As the seeds mature the bur hardens, the hooked spines becoming stiffer as they 
dry out, until finally they are strong enough to cling to the hair or fur of any passing animal.

Fortunately the Cocklebur spreads and multiplies only through its seeds, so that it is comparatively easy to keep in check in cultivated fields by means of clean culture continued late in the season.

\section{Potato Family}

The Horse Nettle is a perennial weed native to the southeastern region of the United States, whence it has gradually spread westward. Its general resemblance in leaf, flower, and fruit to the common potato shows its relation to that plant. The two belong to the same genus - Solanum. The rough, prickly plants attain a height of from one to two feet, bearing good-sized oak-like downy leaves, with long spines projecting from the midrib on both the upper and the lower surfaces. The flowers are white or purple, and develop into round yellow berries. The latter are composed of a pulpy substance in which many small seeds are embedded. These seeds are distributed by birds.

Besides the seeds, the plant spreads and reproduces by slender rootstocks that penetrate the soil in all directions and live from season to season. These make the Horse Nettle a difficult pest to subdue. Clean cultivation and the eradication or starving out of the rootstocks are the best methods.

Like the Horse Nettle, the Buffalo Bur is a native of America, having originally developed upon the plains of the far West, where its burs became entangled in the hairy fur of the wandering buffaloes. Since the advent of the white man, the plant has spread eastward, until now it is found in many regions throughout the country. Like the 
Horse Nettle, also, this plant belongs to the same genus as the potato, the flowers resembling those of this common vegetable in shape, although they are yellow in color. It is an extremely spiny plant, more so than the Horse Nettle, and its fruit develops into spinose burs, inside which are numerous small black seeds. These become attached to

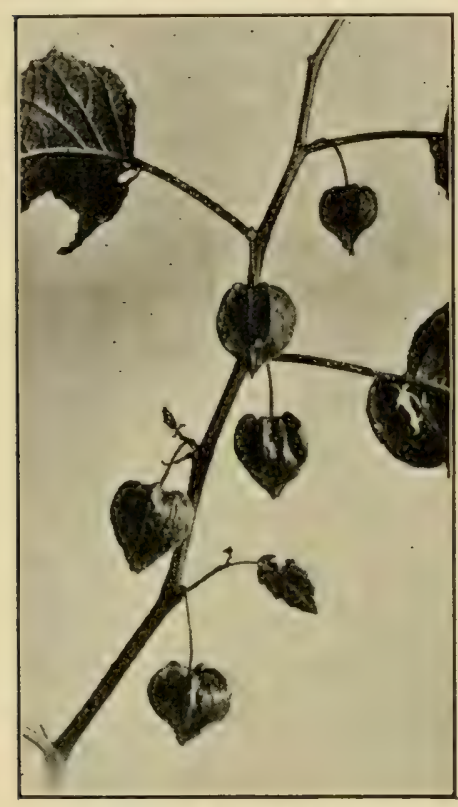

GROUND CHERRY OR

PHYSALIS

clothing or the hair of animals, and are thus disseminated, although the whole plant is sometimes blown from place to place, carrying the seeds with it.

The Buffalo Bur may be kept down, if seeding is prevented, either by mowing or cultivation.

Nearly a score of species of Ground Cherries, of the genus Physalis, are found in North America. All are readily recognized by the curious berry-like fruit inclosed in the inflated bell-shaped calyx that forms a pod-like covering. The foliage resembles that of the tomato. One of the most abundant sorts is called the Husk Tomato, or Strawberry Tomato, and is grown as an edible fruit.

These Ground Cherries are readily kept in check in a well-tilled garden. Most of them are annuals, though at least one is a perennial.

\section{Weeds of Other Families}

Many years ago, perhaps in the days of Pocahontas, a weedy plant appeared in the gardens of Jamestown, 
Virginia. It was a very distinctive species with goodsized, dark green leaves, large white flowers, and curiously spined fruit capsules. It had a decidedly disagreeable odor, and was found to be very poisonous. So the plant became well known, and when it spread to the gardens of the surrounding region, it was called Jamestown Weed, a name that was gradually contracted to Jimson Weed, by

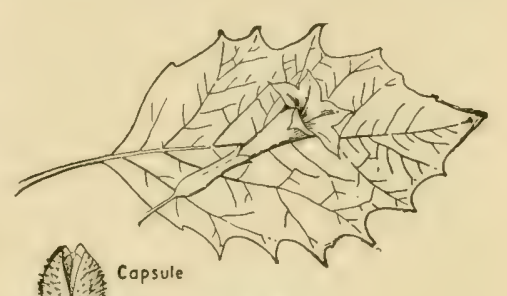

JIMSON WEED which it is now generally known. It is also called Thorn Apple, Jamestown Lily, Apple of Peru, and Mad-apple. Possibly the last name is due to the fact that infusions of leaves have been used for the cure of hydrophobia. Or it may be due to the fact that the plant when eaten produces convulsions and delirium.

In addition to the white-flowering Jimson weed, there is a very similar purple-flowering species. Both are annuals from the tropics, and are especially abundant in the Southern states. Nearly every year children are poisoned by eating the seeds. These plants should be destroyed wherever they are seen.

There are several creeping plants that are troublesome as weeds. One of the worst of these is called the Hedge Bindweed or Wild Morning Glory. Its rootstock is perenrial, while the stem and leaves die down every autumn. Its leaves are somewhat arrow-shaped, and its white or purplish flowers bear a general resemblance to those of the cultivated Morning Glory. It is especially troublesome on low moist land.

The Wild Morning Glory is propagated both by seeds and by the spreading of underground roots. On account of these roots it is a difficult weed to eradicate. Hoeing 
and pulling are effective when only a few of the plants are present.

A similar species is Wild Buckwheat or Black Bindweed. The stems and blossoms of this plant are smaller than are those of the Bindweed, while the flowers, instead of being produced singly on stems, are quite small and clustered together in racemes. It is called Wild Buckwheat because its seeds are quite similar to those of buckwheat. It is an annual species, and consequently is not very difficult to subdue by cultivation.

A number of the more abundant weeds are likely to develop in gardens and plowed fields, during the latter part of summer. In some cases they are really a benefit, in that they enforce surface tillage during the season when a soil mulch is most needed. In fields of corn, potatoes, and some other crops, however, such late tillage is impracticable, and about the only way to fight the weeds is to pull them up by hand.

\section{OBSERVATIONS FOR PUPILS}

I. How many of the weeds treated of in this chapter infest gardens and cultivated fields in your locality? Here is the list:-

\begin{tabular}{ll} 
Barnyard Grass & Hedge Bindweed \\
Black Bindweed & Horse Nettle \\
Buffalo Bur & Jimson Weed \\
Chickweed & Lamb's-quarters \\
Crab-grass & Pigweed \\
Finger-grass & Purslane \\
Fly-away-grass & Quack-grass \\
Giant Ragweed & Ragweed \\
Green Foxtail & Shepherd's Purse \\
Ground Cherry & Tumbleweed \\
\multicolumn{2}{c}{ Yellow Foxtail }
\end{tabular}

2. What other weeds occur in gardens and cultivated fields in your locality? 
3. Make a list of the field and garden weeds you are acquainted with, and print the names in alphabetical order on a page of your booklet.

4. Make a careful study of such of these weeds as your teacher thinks desirable, incorporating the results into your booklet. The following outlines may prove helpful for such studies:-

\section{Purslane}

I. Coint the number of seeds in one "pusley" capsule.

$\therefore$ Count the number of capsules on one long branch.

3. Estimate the number of seeds produced by the plant.

4. Count the number of plants in a space two feet square, and estimate the number of seeds produced in a square rod.

5. How are "pusley" seeds distributed?

6. When do you find Purslane most abundant?

7. Make a drawing of stem, leaf, and fruit.

\section{Lamb's Quarters or White Pigweed}

I. Why should this be called White Pigweed ?

2. Where have you found it most abundant?

3. How are the seeds scattered?

4. Do you know how it looks when young?

5. Have you seen any leaves affected by leaf miners? If so, rear some of the adult flies from them, and see whether they resemble the flies you can easily rear from spinach.

6. How early should the plants be destroyed to prevent their maturing seed?

\%. Draw a good-sized leaf, showing petiole, veins, and margin.

\section{OUtLine FOR OTHER WeEdS}

1. What sort of root has this plant?

2. Does it spread by underground rootstocks?

3. How is it protected from being eaten by animals?

4. When do the flowers appear? Describe them.

5. When do the seeds ripen? How are they scattered?

6. Estimate the number of seeds on one plant.

7. What do the young seedlings look like? When may they be found? 
8. In what condition does the plant pass the winter - in the seed state, or as a living plant, or both?

9. How is it commonly introduced to new fields?

I0. In what ways may it be destroyed or prevented from growing?

I I. Make some or all of these drawings :-

$\begin{array}{ll}\text { Root } & \text { Flower } \\ \text { Leaf } & \text { Seed }\end{array}$

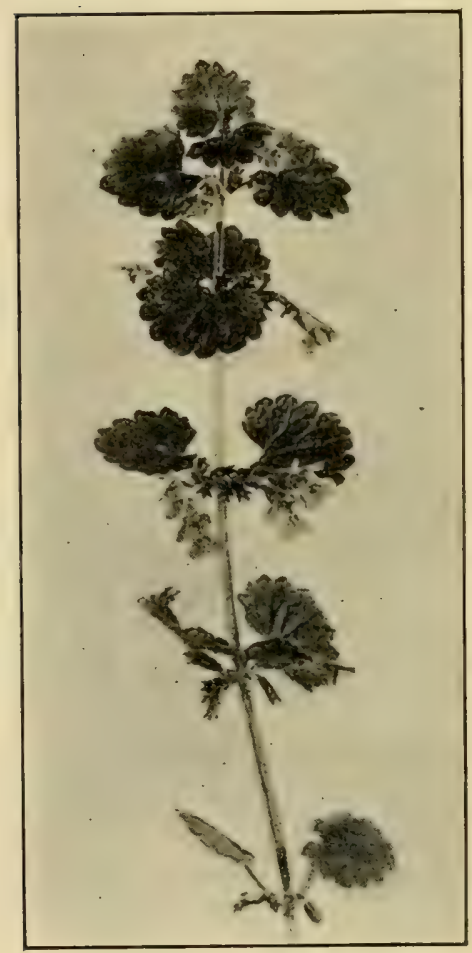

GILL-OVER-THE-GROUND 


\section{CHAPTER IV}

\section{The Weeds of Grain and Forage Crops}

THE weeds that infest fields of grain and forage crops are commonly introduced with the seed. In many cases, however, the weed roots or seeds may be present in the soil because of neglect of crops previously grown upon the land, or the seeds may be scattered through the fields during autumn, winter, and spring before the grain or forage crop is sown. Consequently the surest way to prevent injury in such fields is to sow clean seed and adopt good agricultural methods.

\section{Grass Family}

Perhaps the most notorious grain-field plant is Chess or Cheat Grass. In earlier days there was much discussion in regard to the origin of this pernicious plant. The idea was very commonly upheld that wheat turned to Chess, so that under certain conditions, as it was supposed, a farmer might sow good wheat seed and reap only a crop of Chess. It seems likely that this was the basis for the use of the common name Cheat. It has long been known, however, that Chess comes from seed of its own, and not from wheat, so that when the Chess appears it is certain, either that its seed was present in the ground before sowing or that it was mixed in with fertilizers or the wheat that was used for seeding. It is well established that the seed of Chess may lie dormant in the soil for several seasons, and this 
probably is the explanation of its presence in many grain fields, in which no Chess seed developed the previous season.

Chess is a winter annual, and its slender seeds are somewhat similar to oats, although they are darker in color, and the grain is of smaller size. These seeds are likely to be found in cheap qualities of clover, oats, and wheat seed,

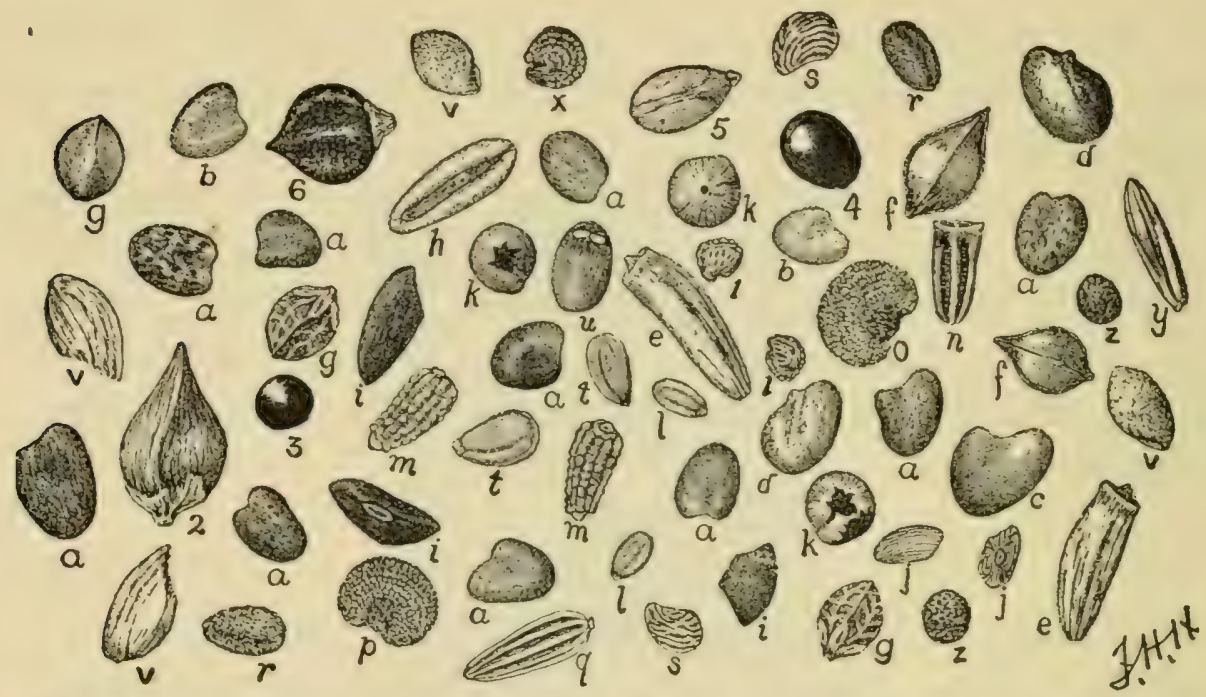

Mixture of weed seeds commonly found in low-grade alsike clover seed: $a$, alsike clover; $b$, white clover; $c$, red clover; $d$, yellow trefoil; $c$, Canada thistle; $f$, dock; $g$, sorrel ; $h$, buckhorn; $i$, rat-tail plantain; $k$, lamb's-quarters ; $l$, shepherd's purse ; $m$, mayweed $; n$, scentless camomile ; $o$, white campion ; $p$, nightflowering catch-fly; $q$, oxeye daisy; $r$, small-fruited false flax; $s$, cinquefoil; $t$, two kinds of peppergrass; $u$, catnip; $v$, timothy; $x$, chickweed; $y$, Canada bluegrass; $z$, clover dodder; $I$, mouse-ear chickweed; 2 , knot-grass ; 3, tumbling amaranth; f, rough amaranth ; 5, heal-all ; 6, lady's thumb. (Enlarged.)

although, as in the case of many other pernicious plants, the public inspection of seeds is driving these poorer qualities out of the market. When a field is infested with Chess, it may well be planted to a hoed crop for two or three seasons. This procedure, and the sowing of pure seed, will prove an adequate preventive. 
In the great spring wheat regions of the Northwest, the Wild Oat is one of the most troublesome weeds in fields of oats. This plant bears a striking resemblance to the ordinary cultivated oats, from which it is easily known by the long-tipped awns borne by the terminal florets of each cluster of flowers, and by the fact that the kernel or grain is very light. When present in an oats field, these Wild Oats mature earlier than the main crop and in an irregular fashion, many of the individual florets dropping away as they ripen. The presence of the plant not only reduces the regular crop, but also sometimes causes trouble because the stiff awns irritate the mouth parts of the animals to which the crop is fed.

The seeds of Wild Oats retain their vitality for a long period when buried deeply in the soil. Consequently, a badly infested field may require several seasons' tillage in other crops before all the seeds present have germinated. A carefully planned rotation is the best method of getting rid of the plant.

\section{Mustard Family}

In many localities, the most vexatious weeds in grain fields are those belonging to the Mustard family. The seeds of these are very commonly mixed with oats and other grains, so they are sown at seeding time. One of the most generally troublesome is the Charlock, Wild Mustard, or English Mustard, as it is sometimes called. This was originally a native of Europe, but is now very generally distributed in America. It is especially troublesome in fields of oats, the young mustard plants growing along with the oats and materially lessening the crop. Charlock is distinguished from the other Mustards by a pod, long and knotted, and having at the tip a rather thick, two-edged beak. 
The Black Mustard is a much more prickly plant, having pods that are more or less oblong, smooth, and four-angled. A single plant of either of these Mustards may produce from I 0,000 to I 5,000 seeds. This accounts for the enormous numbers of them that often appear in neglected fields.

In many parts of Canada and the United States, the Tumbling Mustard or Tall Mustard has recently become a troublesome pest. This species seems to have been introduced with the soil carried as ballast by ships, and dumped on the so-called ballast grounds at Philadelphia. It has since been widely distributed by railroads, and is able to develop under a great variety of climatic conditions. Like the other Mustards, this is an annual. It branches freely, and reaches a height of from two to four feet. The small yellowish flowers are borne along the tips of the slender branches, and are less conspicuous than those of the Charlock. The seed pods are very slender, and are commonly two or three inches long. This species is closely related to the more widely distributed Hedge Mustard, the pod of which is much shorter and of larger diameter.

In the case of all these Mustards, as with most annual weeds, careful cultivation with a hoed crop for a series of years is necessary for complete extermination in a field. The seeds of many of the plants of the Mustard family retain their vitality for several years, so that those which are buried deep in plowing, are likely to be brought to the surface long after they matured, and find favorable conditions for growth. It is especially important that grain used for sowing be free from the seeds of any of these plants.

Numerous experiments have shown that young mustard plants may be killed in grain fields without serious injury to the grain crop by spraying with a solution of one part 
iron sulphate to four parts water by weight. The application should be made on a fair day after the dew has evaporated.

Another member of the Mustard family, which is troublesome in fields of winter grain, as well as in those of flax, is the so-called False Flax. This is a pest from Europe which has been introduced into America comparatively recently. Its resemblance to Flax is indicated by its common name. The flowers and seeds, however, are much smaller than those of Flax. In appearance and habit of growth, it also bears a general resemblance to Shepherd's Purse and Peppergrass. Like these weeds, it may be either an annual or a winter annual; that is, the seeds may germinate in spring and blossom the same season, or they may germinate in autumn, the plants living through the winter and blossoming the next season. As a rule, it is only the latter that mature their seeds, the season in the Northern states being too short for the seeds of those plants that germinate in spring to reach maturity.

False Flax is generally introduced as a mixture in flax seed, clover seed, and various grass seeds; consequently all such seeds should be carefully examined before being sown. When the pest has become established, rotation with a hoed crop is necessary to exterminate it.

\section{Weeds of Other Families}

The Cockle or Corn Cockle is a well-known pest in grain fields. Its presence is generally due to impure seed, the black seeds of the Cockle being sown with the wheat or other grain. It is an annual, so that it causes little trouble unless sown with the seed. It grows to a height of three or four feet, and has a slender stem with very few branches, each of which bears on its tip a good-sized reddish-purple 
blossom. There are comparatively few of the long, narrow leaves, which, with the stem and outer part of the flowers, are covered with a coat of fine hairs.

The dark purple or blackish seeds are produced in an oblong pod. They are threshed with the wheat; and as they are nearly the size and weight of the wheat kernel, it is very difficult to separate the Corn Cockle seeds from the grain. In consequence the flour is of inferior quality. The presence of the seeds is shown by the black particles of the pulverized seed coat. Flour badly contaminated by Cockle seeds is injurious when eaten, as they contain a poisonous principle that produces disease and death.

The Cockle plants are easily pulled up in wheat fields and should be removed, especially from all fields that are intended to produce seed grain.

Few weedy plants have such distinctive beauty as has the famous Field Poppy or Corn Poppy of the English poets. In England the fields of wheat are called corn fields, although in America this term is usually restricted to Indian Corn. The Field Poppy has long been a pest in European wheat fields; but it gives to the landscape a glow of scarlet color, much as our own meadows are decorated with the Oxeye Daisy. This Field Poppy has been introduced into many regions in America, probably through adulterated seed, and threatens to become troublesome wherever it appears. It is so conspicuous a plant that it can scarcely be overlooked, and when first introduced into a locality it should be exterminated. This is also one of the garden Poppies and of course there is danger that it may spread to cultivated fields.

The famous Russian Thistle or Russian Tumbleweed is another European plant that has become destructive in America. The history of the introduction of this pest has 
been carefully traced. Apparently it was first brought in by immigrants from Russia in the great Northwest, about I873, and since then it has spread with marvelous rapidity, not only by being blown across long stretches of prairie, but also by means of railroad trains, and probably in other ways. It has attracted more attention than any other weedy plant of recent introduction, and has been the cause of a great awakening in regard to the whole subject.

The Russian Tumbleweed is an annual that starts as a slender seedling bearing a general resemblance to a very young pine tree. Its leaves are slender, soft, and velvety. It grows rapidly, however, and toward midsummer takes on a spiny appearance, spreading out to cover an area three or four feet in diameter, with the height nearly as great, and a rounded outline similar to that of our common Tumbleweeds. When the seeds are finally mature and ready to be dispersed, the main stalk breaks off at the surface of the ground and the plant rolls away. It then justifies its German name "Wind Witch," or its Russian name "Leap the Fields." With the impetus given by a violent wind, the plants go rolling and tumbling across the prairies, to be caught in great windrows when an obstacle interferes. As they roll along they drop their seeds by the way, so that the country traversed is likely to become thoroughly infested.

While the greater part of the weeds that infest grain fields arise from seeds present or introduced, it sometimes happens that when meadow or pasture land is broken up and planted to grain, there is trouble from perennial weeds whose roots or rootstocks remain in the soil. Thus, if a meadow is infested with milkweeds and is planted to oats, the milkweeds will multiply rapidly under the favorable 
conditions for their growth. In such cases rotation with a hoed crop is desirable.

\section{The Parasitic Dodder}

All the weeds so far discussed in this chapter injure the crop by robbing the soil of food and moisture, or by occupying the space above the soil to the exclusion of the cultivated plants. There is one group of pernicious weeds, however, which do more than this, for they actually attack the green tissues of the crop and rob them of the lifegiving sap. These plants are commonly called Dodders, and there are several species that attack different crops. In their life history, however, they are very similar to one another.

The young Dodder plant starts from a seed well stocked with nourishment. When the seed germinates, this nourishment enables it to develop into a seedling which soon comes in contact with the stalk of some green plant. Then the little Dodder sends out from along the sides of its own stalk curious rootlike projections that penetrate the tissues of the other plant and draw out the sap. There is thus established the relation of parasite and host: the parasite is the Dodder sucking the life sap from its victim, which is the host plant. The root and lower stem of the Dodder soon wither. In the case of clover, which is often infested by Dodder, the clover plant continues to grow, having roots in the ground and leaves in the air, but those clover stalks which are attacked by the Dodder become dwarfed as well as hard and woody.

As the Dodder grows, it constantly twines around more stalks of its host plant, sending into their tissues more of the rootlike suckers, and after a time developing small blossoms which later mature into seed. As the Dodder is 
a parasite, it has none of the green coloring matter of most plants, for it is not able to manufacture starch and other organic material from the inorganic substances in earth and air. Instead of this, it utilizes for its growth the materials thus organized by the green leaves of its host. The Dodders are commonly yellow or orange in color. They have no leaves.

The seeds of Dodder are a common impurity in many grain, grass, and forage seeds. Such seeds should, of course, be carefully inspected before planting, and if seriously infected should not be used. When a field is already infested, the Dodder may be destroyed by mowing and removing the crop before the Dodder blossoms, or later the crop may be mowed and the ground burned over after the crop thus cut has dried sufficiently to burn. In Western alfalfa fields Dodder is often troublesome the first year after seeding, though less so in later years.

\section{Preventive Measures}

Any study of the weeds that infest grain and forage crops makes it obvious that the most important methods of preventing injury by such pests are: first, the sowing of clean seed, that is, grain free from the seeds of weedy plants; second, the use of fertilizers free from weed seeds; and third, a proper rotation with other crops. To insure pure seed, constant inspection by state and government officials of all seeds offered for sale is necessary. To insure fertilizers free from weed seeds, care in feeding domestic animals is necessary. To insure proper rotation of crops, the adoption of improved agricultural methods in every community is necessary. With these conditions right there need be little trouble from weedy plants in any locality. There is always danger, however, that some new 
pest will be introduced, and it is very desirable that the people of each community should be on the alert for such newly introduced weeds. In order that they may do this, each school should have a collection of weeds and their seeds for reference, and a study should be made of the weedy plants of the locality. Any unknown plants may be sent to the State Experiment Station, or to the Department of Agriculture at Washington for determination.

\section{OBSERVATIONS FOR PUPILS}

I. What weeds have you observed in connection with such of the following crops as are largely grown in your locality:-

\section{Alfalfa \\ Alsike Clover \\ Oats \\ Red Clover \\ Wheat}

2. Is there any evidence to show that part of these were introduced with seed?

3. Examine with a lens samples of forage plant seeds for sale in your locality. Compare the seeds with the pictures in Farmers' Bulletin 382.

4. Determine the percentage of adulteration of the crop seed with other seeds.

5. If you are unable to determine what seeds are present as adulterants. send samples to your State Experiment Station or to the Seed Laboratory, Department of Agriculture, Washington, D.C.

READ such references in these publications as your teacher directs :-

Dodder in Relation to Farm Seeds, Farmers' Bulletin 306. The Adulteration of Forage-p'ant Seeds, Farmers' Bulletin 382. 


\section{CHAPTER V}

\section{The Economics of Weeds}

Every farmer realizes that weeds are among the most important factors in success or failure in agriculture. They occur wherever the soil is cultivated and stand ever ready to take the place of the crop planted if proper tillage is not given. They not only rob the crop of sunshine and needed space in earth and air, but they also deprive the soil of more or less of its available plant food, draw out its moisture, and according to the present belief of some authorities actually poison the soil for other plants.

Weeds, however, are by no means to be considered an unmixed evil. In many cases they are rather to be thought of as a blessing in disguise, for they compel that tillage of the land which is necessary for the conservation of moisture and the healthy growth of most crops. "The truth is," writes L. H. Bailey in a famous paragraph, "that weeds always have

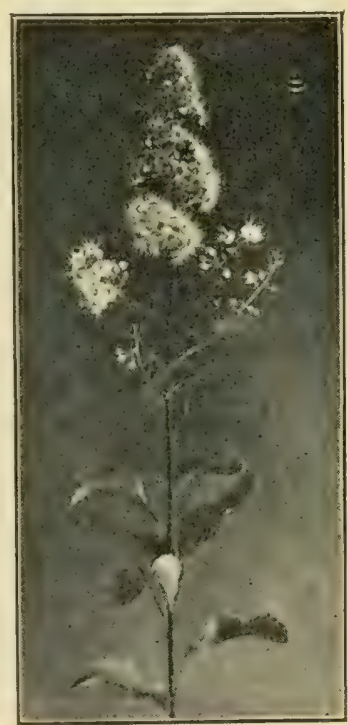

MEADOWSIVEET been and still are the closest friends and helpmates of the farmer. It was they which first taught the lesson of the tillage of the soil, and it is they which never allow the lesson, now that it has been partly learned, to be forgotten. The one only and sovereign remedy for them is the very 
tillage which they have introduced. When their mission is finally matured, therefore, they will disappear, because there will be no place in which they can grow. It would be a great calamity if they were now to disappear from the earth, for the greater number of farmers still need the discipline which they enforce. Probably not one farmer in ten would till his lands well if it were not for these painstaking schoolmasters, and many of them would not till at all. Until farmers till for tillage's sake, and not to kill the weeds, it is necessary that the weeds shall exist, but when farmers do till for tillage's sake, then weeds will disappear with no effort of ours.'

While the beneficence of weeds as a whole must be admitted as a fortunate fact, it is also true that often they are not even a blessing in disguise. Like other things in Nature, the laws that govern them involve many inconveniences in special cases. Rain is a blessing, but sometimes it causes suffering and loss of property and even of life. Winds are necessary, but of ten do serious harm by their violence. With spuo weeds, as with these direct forces of Nature, man must adapt his operations to suit the conditions that he finds upon his land in his efforts to make it productive.

Examples of weeds that could easily be dispensed with are readily pointed out. The Mustard in a newly planted grain field does not indicate that tillage is needed, although it does indicate that there has been carelessness in seed selection. During rainy seasons the hoe and cultivator must frequently be kept in operation to subdue weeds much oftener than any requirements of the crop alone would necessitate. The weeds that appear late in the 
season in corn and potato fields require hand pulling because tillage then would injure the crops, and often even hand pulling involves some loss through the disturbance of the roots.

The most famous definition of a weed is that it is a plant out of place. In soil devoted to a crop of a given kind, the presence even of other crop plants is generally not wanted. So under some circumstances our ordinary grains, vegetables, and flowers may appear as weeds. In fact, in the case of the flowers many weeds have originated as garden escapes, and there is always danger that new ones may be so introduced.

\section{The Struggle for Life}

It is well known that the most troublesome weeds are those best equipped in the struggle for life. By being able to grow quickly where other plants grow slowly, by producing many seeds where other plants produce few seeds, or by being able to do anything else that enables it to get on in the world better than its neighbors a plant has an advantage that tends to make it a weed. There is always an intense struggle for soil, moisture, air, and sunlight, and the plants best fitted to take advantage of conditions existing at a given time and place will win. It is the farmer's business so to plan his operations that the crops he sows will have the advantage of all weedy intruders.

One of the chief advantages that most weeds have in the struggle for life lies in the production of great numbers of seeds. This is well shown in the following estimates by the Kansas Experiment Station of the number of seeds ripened by one plant, made after careful studies of each species:- 
NAME OF WEED

Number of Seens

Purslane

69,000

Velvet leaf .

Ragweed

Cocklebur .

Beggar-ticks

Redroot

Tumbleweed

Crab-grass .

Yellow Foxtail

31,900

23,100

9,700

10,500

85,000

14,000

89,600

I I 3,600

When plants are able to multiply at this rate, it is easy to see how readily they might overrun the earth.

\section{Methods of Distribution}

Under the conditions of Nature weeds are dispersed in almost all the many ways in which plants spread. They are carried by wind, water, and animals, and exhibit numberless devices for taking advantage of these agencies. The study of these devices is of great interest.

Under the conditions of modern agriculture, however, man plays an important part in the distribution of weeds. Vast numbers of seeds are carried from place to place in hay, ballast, and packing materials, and even more are dispersed as impurities of grains and commercial seeds.

During recent years enormous numbers of weed seeds have also been distributed in the various stock feeds upon the market. Many investigations have shown that a large part of these seeds are not digested, so that when they reach the fields from the barn they germinate quickly. As a rule these seeds are not readily detected in the feed because they are mingled with chaff and grain or smeared over with molasses. By careful studies, however, experiment station officials have been able to identify and count these seeds and to show the danger in the use of such feeds. 
The Connecticut Experiment Station has shown that in the case of eleven feeds upon the market, there were the following numbers of weed seeds in one pound of each :-

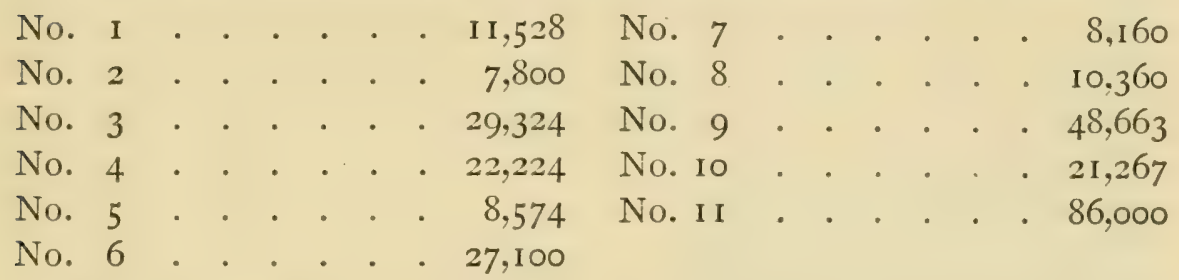

The seeds thus present in such enormous numbers belonged to a comparatively few species of the most troublesome weeds. Among the most abundant of these were the foxtail grasses, white pigweeds, knot-weeds, charlock, black mustard, ragweed, sorrel, docks, and thistles. "All of these weeds are characteristic of grain screenings which are the refuse separated from the grain, in order to make the latter marketable or fit for milling. These screen-

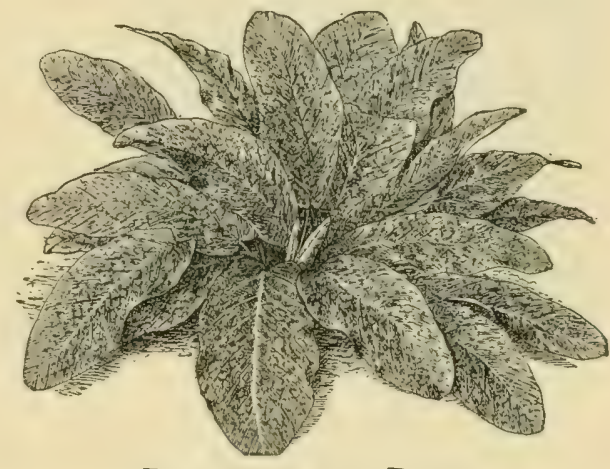

BROAD-LEAVED DOCK

Growth of First Season ings vary a good deal in quality. Thus an analysis recently made here of wheat screenings showed about 33 per cent of flax and shrunken cereal, I 5 per cent of foxtails, 8 per cent of bindweeds and pigweeds, I 5 per cent of weed seeds of other species, and 2 I per cent of dust, broken seeds, and sand."

\section{LENGTH OF LifE}

One of the most important considerations in regard to any weed is its length of life. If it lives but one 
season, it is likely to be less dangerous than if it lives two or more seasons. Like other plants, weeds are commonly grouped as ammals, living but one year, bicmials, living two years, and percnnials, living many years. The phrase wintor anmuals is given to those plants that start their growth in autumn and finish their development the following spring or summer.

The remedial measures to be taken against weeds depend largely upon the term of life. The annuals live from year to year by means of their seeds. Consequently the prevention of seeding by tillage or other means and the destruction of the seed are the most important general measures. It has lately been found that some annuals like the mustards may safely be killed in grain fields by spraying with a weak solution of iron sulphate. The biennials reproduce also by seeds, and are to be treated much as the annuals. The perennials commonly reproduce both by seeds and by rootstocks or other vegetative growths, so that their destruction is generally more difficult than in the case of the annuals and biennials.

The methods that may be employed for the destruction of the roots or rootstocks of perennial weeds have been well summarized by L. H. Dewey in these words :-

(I) They may be dug up and removed, a remedy that can be practically applied only in small areas.

(2) They may be killed by applying chemicals either to the freshly cut root or at the base of the main stem. Salt, strong brine, coal oil, crude sulphuric acid, and carbolic acid have been successfully used for this purpose. A few drops of carbolic acid applied at the base of the main stem with an ordinary machine-oil can is the best method that has been yet devised for killing weeds with chemicals (except spraying with sulphate of iron). 
(3) Rootstocks or perennial roots may be starved to death by preventing any development of green leaves or other parts above ground. This may be effected by building straw stacks over small patches, by persistent, thorough cultivation in fields, by the use of the hoe or spud in waste places, and by salting the plants and turning sheep on in permanent pastures.

(4) The plants may usually be smothered by dense sod-forming grasses or by a crop like clover or millet that will exclude the light.

(5) Most rootstocks are readily destroyed by exposing them to the direct action of the sun during the summer drought, or to the direct action of the frost in the winter. In this way plowing, for example, becomes effective.

(6) Any cultivation that merely breaks up the rootstocks and

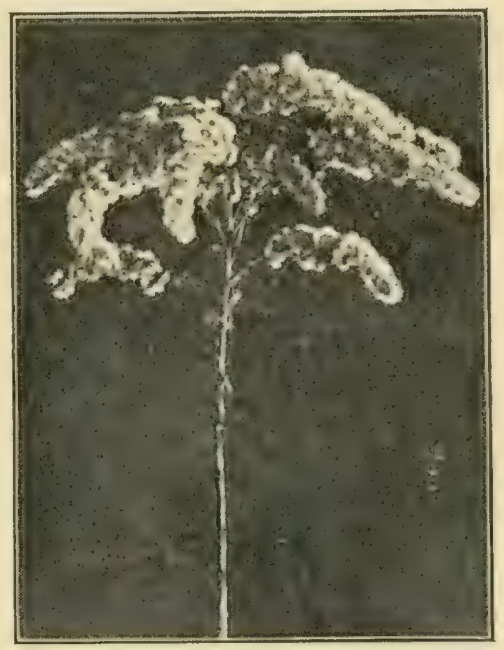

Goldenrod Seedheads leaves them in the ground, especially during wet weather, only multiplies the plant and is worse than useless, unless the cultivation is continued so as to prevent the growth above ground. Plowing and fitting corn ground in April and May, and cultivating at intervals until the last of June, then leaving the land uncultivated during the remainder of the season, is one of the best methods that could be pursued to encourage the growth of couch-grass and many other perennial weeds.

Recent studies by Spillman and Cates have shown that the rootstock grasses, like quack grass, Bermuda grass, and Johnson grass, are readily killed out by allowing the fields to become meadows and pastures, so that a dense sod will 
form. Then cut or feed off the grass frequently to induce a shallow development of rootstocks. These may then be turned up by shallow plowing and destroyed by clean culture, summer fallowing, or winter freezing.

\section{LESSONS FROM WEEDS}

The most important general lessons we may learn from our study of weeds are, first, that good agriculture is the best preventive of their injuries, and, second, that this must be practiced not only by all the farmers of a given community, but by all farmers everywhere. So it becomes the duty of each one to adopt the best methods practicable on his own farm as well as to encourage in every way possible the practice of such methods in every locality.

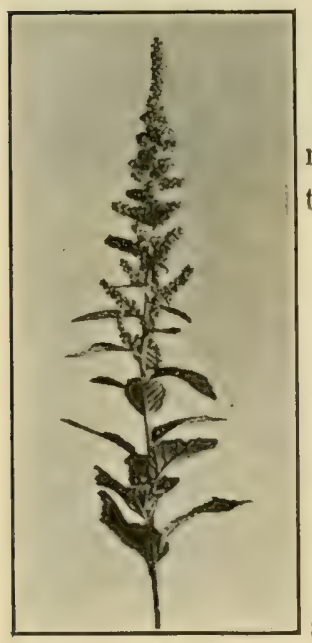

HARDHACK

\section{OBSERVATIONS FOR PUPILS}

Choose certain weeds which you have not before reported upon and see if you can answer these questions about each :-

I. Where did it come from?

2. How does it spread?

3. How long does it live ?

4. How does it pass the winter?

5. How does it injure the crop?

6. Is it poisonous or hurtful to domestic animals ?

7. In what ways may it be destroyed?

When you have a composition to write, choose some weed for a topic and use these questions as an outline for your guidance. 


\section{PART II}

FRIENDS AND FOES AMONG THE INSECTS 


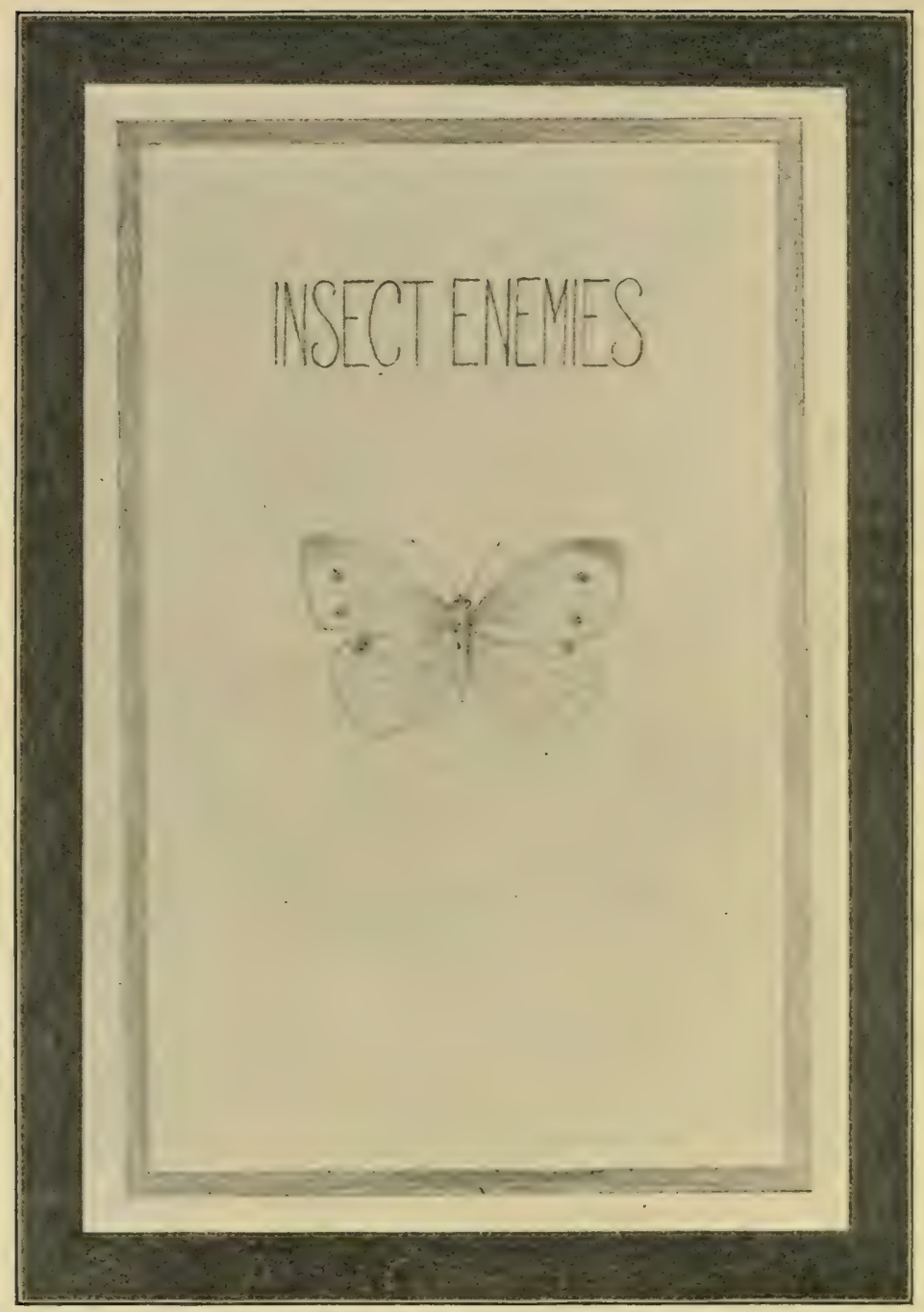

COVER DESIGN FOR A BOOKLET ON INSECTS

\section{The Booklets on Insects}

At least two insect booklets may be prepared by each pupil, one on Insect Enemies and another on Insect Friends. The drawings and reports upon the Observations for Pupils suggested at the ends of the chapters will furnish abundant material for voluminous booklets.

In making drawings of insects so as to show a back view with each side symmetrical, a butterfly with wings spread, for example, it is best to draw one half beside a straight line, then to transfer this half by means of tracing paper to the other side of the line. It is easier thus to get both sides alike. 


\section{CHAPTER VI}

\section{Orthoptera: the Grasshoppers, Crickets, and Cockroaches}

The Grasshoppers, Crickets, Cockroaches, Walking Sticks, and a few other species make up the order of straightwinged insects called Orthoptera. Practically all of them are injurious, or capable of becoming so. With the exception of the Tree Crickets and the Mantids few of them are likely to be of great service to man, except possibly as a source of food to poultry.

The insects of this order are characterized by having biting mouth parts, incomplete transformations, and four wings - the front pair usually being thickened, while the hind pair are membranous and folded like a fan beneath the front ones. This is a comparatively small group, but one in which there are some very destructive species. In America the Rocky Mountain Locust has done enormous damage. In the Old World the locust plagues of both ancient and modern times were due to insects belonging to this order.

\section{Structure of a Grasshopper}

If you examine a grasshopper carefully, one of the first things you notice is that the body is divided into three important sections. At the front end is the head; next to this are two closely connected parts that bear the legs and wings and together form the thorax; next to the thorax is a part divided into rings - the abdomen. 
The head varies greatly in shape with different species of grasshoppers, but in general it is larger above than below. From near the middle of the front there project two slender feelers or antcnuce, each of which is composed of
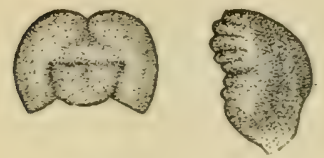

b

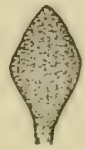

C

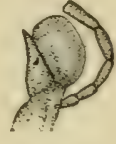

d

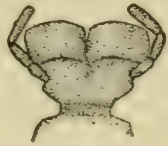

e

MOUTH PARTS OF Grasshopper

$a$, labrum; $b$, mandible; $c$, tongue; $d$, maxilla ; $e$, labium. Magnified. a number of distinct rings or segments joined together. Just above the base of each antenna is a large compound eye, the surface of which through a lens resembles the surface of a honeycomb. Each eye has a great number of hexagonal divisions: these are the facets which make up the compound eye. There are three simple eyes on the grasshopper's head - two between the compound eyes and one in the middle line above. These are very different in structure from the compound eyes, being merely small, round, lenslike objects. These simple eyes are often called ocelli.

Below are the mouth parts of the grasshopper. Beginning from above, we see first a large four-sided flap or lip, which moves up and down on a basal hinge ; this is the upper lip or labrum. Be-

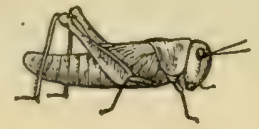

Nymph

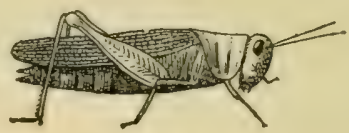

Adult

GRASSHOPPER

neath it there is a pair of rather large jaws or mandibles attached so as to move sideways, and having sharp, toothed, cutting edges. On the inside of the mouth between the mandibles is the tongue; and below this are the second jaws or maxille, while still lower is the underlip or labium, with its labial palps or feelers. 
Directly back of the head, there is a large capelike segment bearing a pair of legs. This is the first division of the thorax, and is called the prothorax. The remainder of the thorax is made up of two parts united. The one in the middle is the mesothorax; this bears the front wings and the middle legs. Behind this is the metathorax; this bears the hind wings and the hind legs.

The front wings are long and slen-

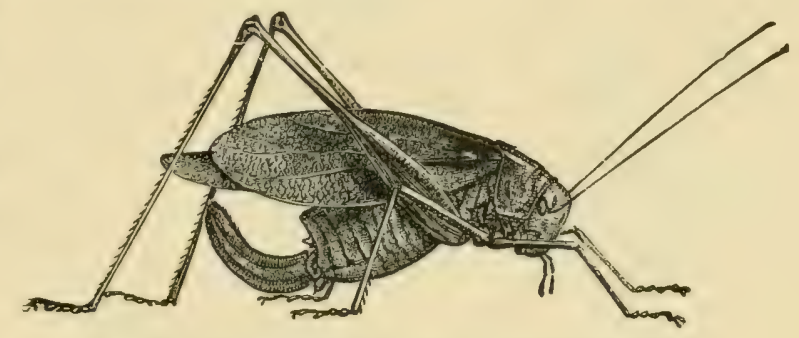

OBLONG I.EAF-WINGED GRASSHOPPER der, and when at rest serve as a protective covering to the hind wings. The latter are then folded in longitudinal plaits like a fan. When the grasshopper is flying, the front wings are extended at right angles to the body, and the hind wings are stretched out.

The abdomen is composed of a number of joints or $\operatorname{seg}$ monts, which move freely upon one another at their points of contact. In female specimens the abdomen ends in four-pointed projections by means of which the hole in the ground for the eggs is made; these form the ovipositor or egg-depositor.

\section{SHORT-HORNED LOCUSTS}

The common Grasshoppers or short-horned Locusts form one of the most important families (Acridiida). These have short antennæ or "feelers," short ovipositors, and but three joints to the tarsi - the short joints at the ends of the legs. They feed upon grasses and other forage crops, and are often very destructive. In many of the males, there is a sound-producing apparatus. 
The Red-legged Locust is one of the commonest members of this family. Its eggs are laid in the ground

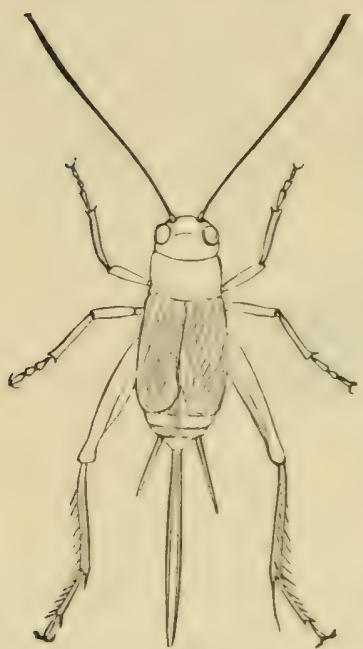

COMMUN CRICKET

Female early in autumn and remain there through the winter. The next summer they hatch into small grasshoppers that resemble the adult in general appearance, but of course are much smaller and have no wings. They molt or cast their skins several times during the next six weeks, and then they become full grown with welldeveloped wings.

The famous Rocky Mountain Locust is very similar to the Red-legged species. Fortunately it is unable to develop continuously except at high altitudes, such as the plateaus of the Rocky Mountains. Here it used to become so abundant that it was forced to migrate for food. At such times, enormous numbers of the grasshoppers flew toward the Mississippi Valley, where they fed upon all kinds of grasses and grains and many other plants. As they came suddenly in enormous swarms, it was impossible to fight them successfully, and they often did great damage.

There are many other species of grasshoppers belong-

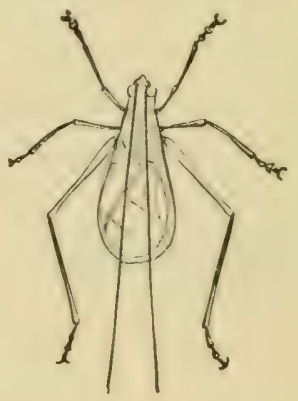

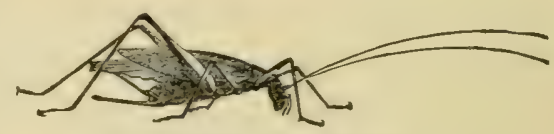

TREE CRICKETS

Male above; female below ing to this family, which are common and widely distrib- 
uted. The Carolina Locust is one of the most familiar. It is abundant along roadsides and may be known by its hind wings with yellow borders. The Bird Grasshopper is our largest species.

\section{Meadow Grasshoppers}

The more slender Meadow Grasshoppers or Long-horned locusts form another distinct family (Locustidx). These have long, slender antennæ or "feelers," conspicuous, sword-shaped ovipositors, and four joints to the tarsi. Nearly all the members of this family are green in color. They live chiefly on grasses and other herbaceous plants, though some species are common in trees and shrubs. The Meadow Grasshoppers, the Katydids, and the wingless cricket-like Grasshoppers are the important members of this family.

\section{Cricket Family}

The family to which the Crickets belong is called the Gryllidæ. These insects are characterized by having hind legs adapted to jumping, long, slender antennæe, and horizontal wings with the outside edge turned down at a right angle to the main part. In most Crickets there are peculiar projections called stylets at the hind end of the body, and there is usually in the females a spear-shaped ovipositor.

The principal types of Crickets are Tree Crickets, Black Crickets, and Mole Crickets. The first live on trees and shrubs above ground, the second on the ground, and the third in holes in the ground. In the case of the Black Crickets, eggs are deposited in the soil early in autumn and remain unhatched until the following season. Some specimens, however, are generally to be found in winter in 
a half-grown condition, so that these insects may hibernate in two stages of their life.

The Tree Crickets are generally greenish or whitish insects, living on the leaves and branches of trees, shrubs,

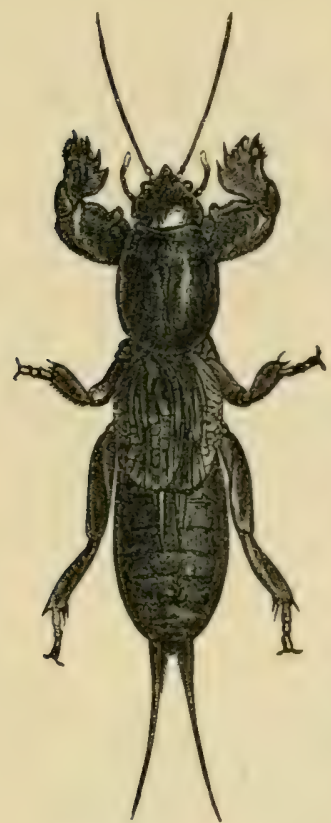

MOLE CRICKET and herbs. They feed upon plant lice or aphides, and thus differ in their food habits from most of the order. But they often do considerable damage to raspberry canes by depositing their eggs in long rows in the pith. Such canes are likely to split open and winter-kill.

The Mole Crickets are among the most remarkable examples of insect life. They are perfectly adapted to an underground, burrowing life. The front legs are developed into digging organs by means of which the insect can make a tunnel in the soil, through which the cylindrical body easily passes. They are brown in color, and their food consists of underground roots of various sorts.

\section{Cockroaches and Walking Sticks}

The Cockroaches (Blattidæ) are characterized by their flattened forms, their legs fitted for running, their flat overlapping front wings, and their long, bristlelike, many-jointed antennæ. Many forms of Cockroaches are wingless, though the typical full-grown form has well-developed wings. These insects feed upon almost anything, being commonly found about kitchens and sheds, especially where there are water pipes. Some species are also found in the woods, under the bark of trees, where they feed upon a variety of materials. Probably the original home of all the species 
was in the forest. The eggs are deposited in curious little brown packets, that may often be found under the loose bark of fallen logs.

The only other important members of the order Orthoptera are the Walking Sticks, which occasionally are injurious, and the Mantids, which are generally useful in that they feed upon various sorts of destructive insects.

\section{OBSERVATIONS FOR PUPILS \\ Short-horned Grasshoppers or True Locusts \\ $A$}

I. Get a few good-sized grassheppers - the larger the better. Kill them in a cyanide bottle or by immersing in alcohol. Study the structure carefully to see if you can make out all the details mentioned on pages $65-67$ of this chapter.

2. Collect a lot of grasshoppers in a meadow or pasture. How do the young differ from the adults? Rear a few in a vivarium, feeding with clover or grass.

3. Place a piece of sod in the bottom of a box or a wicle glas: cylinder. Put a few full-grown grasshoppers in also. See if you get eggs laid.

4. Look up some of these references:-

The Insect Book, pages 332-335. American Insects, pages I36-I47. Nature Biographies, pages 89-95. Life Histories of American Insects, pages 67-81.

B

I. Write or tell a story with this title : The Life of a Grasshopper. Describe :-

Where and when the eggs are laid.

What the eggs look like.

When the eggs hatch.

What the young grasshoppers look like.

The growth of the young grasshoppers.

Their food.

When they become full grown.

2. Illustrate your story with sketches: if written, draw on paper; if told, draw on the blackboard. 


\section{LONG-HORNED OR MEADOW GRASSHOPPERS}

I. Get a few Meadow Grasshoppers of different kinds and put in a vivarium. Feed with clovers or grasses.

2. In what ways do these differ from the true locusts or common grasshoppers?

3. Watch to see if you can find out just how they sing.

4. Look up some of these references:-

The Insect Book, pages 336-340. American Insects, pages I49-156. Stories of Insect Life, Second Series, pages 6-Io.

\section{CRICKETS}

I. Collect some Black Crickets and keep in a glass vivarium with sod in the bottom. Observe whether you can see them move their wings as they sirig. See if you can get some to lay their eggs.

2. You can generally get Tree Crickets in summer and autumn by beating branches of trees and shrubs over an open inverted umbrella. Keep some in a vivarium, providing aphides for them to feed upon.

3. Look up some of these references:-

The Insect Book, pages 341-344. American Insects, pages 157-16r. Life Histories of American Insects, pages 45-58.

\section{WALKING STICKS}

I. You can often get live Walking Sticks by beating branches over an umbrella. Keep in a vivarium and insert leafy twigs for food. Notice how quiet the insects remain by day.

2. Look up these references:-

The Insect Book, pages 323-325. Nature Biographies, pages 58-63. 


\section{CHAPTER VII}

\section{Hemiptera: The True Bugs}

While the word bug has been in common English use for a long time as applying to an insect of almost any kind, the entomologists restrict the word to a certain group of insects which they call Hemiptera or Half-winged Insects. The mouth parts of the members of this order are formed for sucking, and the transformations are incomplete, their life changes resembling those of the grasshoppers rather than those of the butterflies and moths. An immense number of noxious insects are included in this group, some of the most notorious being the Squash Bug, Chinch Bug, the various kinds of aphides or plant lice and of the scale insects or bark lice, the Periodical Cicada, and many other equally injurious pests.

The life history of these insects is well illustrated by that of the common Black Squash Bug. This pest appears in the garden in early summer, and the females soon deposit their eggs upon the young squash plants. These eggs are small, rounded objects, more or less triangular in their general outline. In from six to fifteen days they hatch into tiny

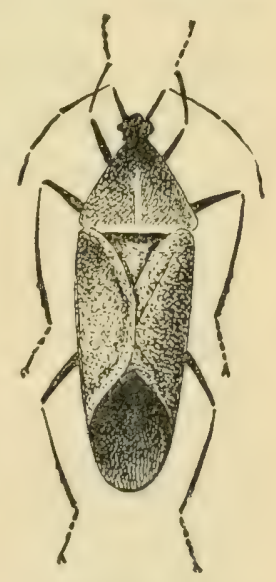

Sr)UASH BLG Magnified bugs, which grow into the form and size of the parents.

The newly hatched Squash Bug is more brilliantly colored than at any later time in its life, and these colors make it very conspicuous against the green background of the 
leaves. The abdomen and the hind part of the thorax are light green; the legs and feelers or antennæ are a beautiful crimson; the head and front part of the thorax are a light crimson; while the margins of the eyes are darker. This brilliancy, however, lasts for a short time only. An hour after hatching, the crimson is noticeably darker, and in a few hours the insect is nearly black.

The young Squash Bugs soon begin their attacks upon the plant by inserting their tiny beaks into the succulent tissues of the leaves. In their general habits they resemble the adults. After about three days of this feeding, the abdomen becomes noticeably swollen and the color somewhat lighter. This is an indication that the period of molting has arrived. These young bugs are often called larace or nymplis. They now assume a quiet, stationary attitude. The process of molting begins by the splitting of the skin lengthwise along the middle of the back, the split extending along the thorax and the front of the abdomen. The time required to complete this molting operation varies greatly, but generally is not longer than an hour or two.

A few hours after the first molt, when the bugs have taken on their normal color, they are considerably lighter than before. They are also more alert. They feed again upon the sap of the leaves for about nine days, when they undergo their second molt. After this has taken place, so that the nymph is in its third larval stage, the body is larger and flatter, with the margins more sharply defined and the color somewhat darker than in the second stage.

The most notable difference shown by the insect in the fourth stage, which is entered upon by the third molt about eight days after the second, is the noticeable development of the wing pads. These become more conspicuous than 
before. After living in this fourth stage for about a week, the insect molts for the fourth time, entering upon its fifth stage. It is now quite different in appearance, and is easily recognized as a full-grown nymph, - a condition analogous to the pupa state of butterflies and moths, in that it is the stage immediately preceding the adult. The wing pads are greatly enlarged, while the thorax is widened and lengthened. The body is more rectangular and so similar to a mature bug that at a little distance it may readily be mistaken for the latter.

The full-grown nymph lives in this fifth stage about nine days before the final molt, by which it matures into the adult Squash Bug.

\section{The Chinch Bug}

The Chinch Bug has a life history similar to that of the Squash Bug, but it does much more damage because it attacks the great grain crops - corn, wheat, oats, and similar staples. The areas in which it occurs in greatest abundance are shown by the dots on the map below. It has been estimated that during the sixty years from 1850 to I9IO the losses due to this insect exceeded $\$ 300,000$ coo.

The full-grown Chinch Bugs pass the winter in the shelter of thick grass, fallen leaves, or other protection, and come forth in the spring. They then scatter to such grain crops as they can find. Here they lay their eggs, one bug often laying four or five hundred eggs. The young bugs soon hatch and attack the grain plants by sucking the sap

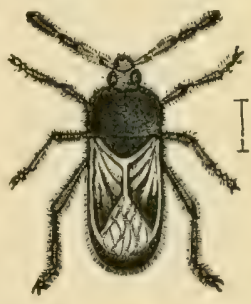

CHINCH Bug

Magnified through their pointed beaks. When they are abundant, they actually hide much of the surface of the leaf or stalk, and of course kill the plants. 
The young Chinch Bugs pass through a series of molts very similar to those of the Squash Bugs. Those that hatch from eggs laid in spring become full grown about midsummer or a little later. They then lay eggs for another brood. These become full-grown before winter and hibernate in such protection as they can find.

The destruction of Chinch Bugs in their winter quarters is one of the most effective remedial measures. By burn-

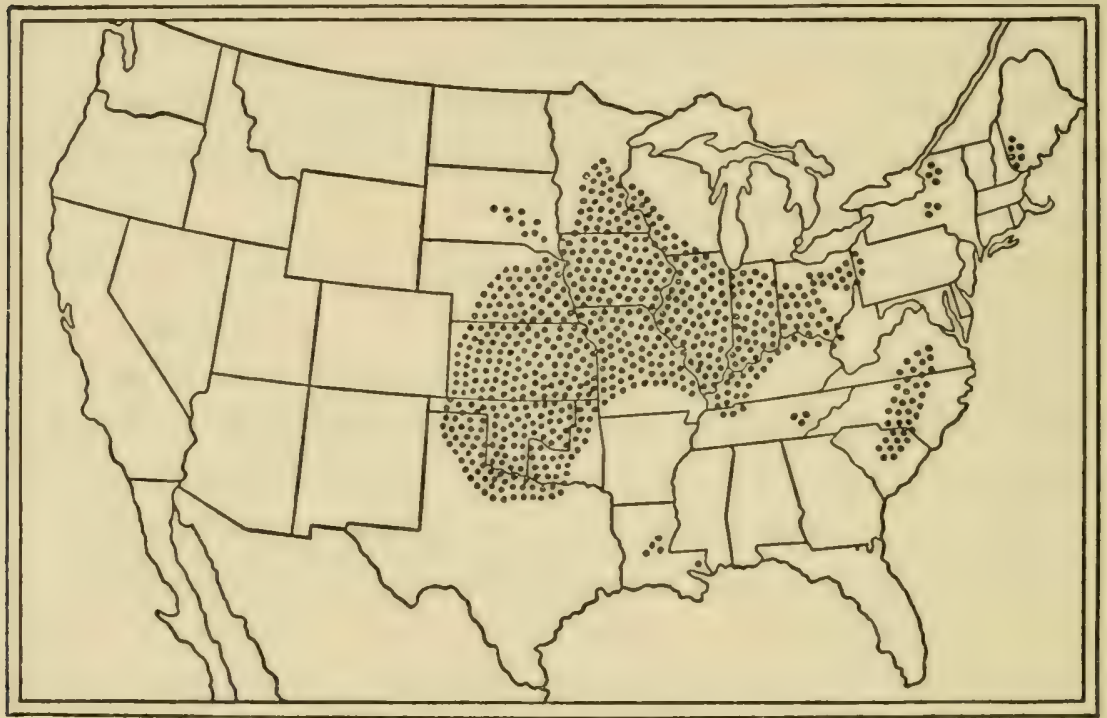

Areas over which the Chinch Bug occurs in Most Destructive NUMBERS

ing over strips of grass lands along fences late in the fall or early in the spring, many bugs may be destroyed. They may also be attracted to strips or patches of trap crops, such as millet, wheat, or corn, where they may be plowed under or otherwise killed. They are often trapped in furrows and killed by spraying with kerosene.

Under certain weather conditions these bugs may be killed in vast numbers by the Chinch Bug Fungus-a parasitic disease that spreads rapidly in moist air. This 
disease has been propagated artificially and distributed over wide areas by state officials to good advantage.

\section{Harlequin Cabbage Bug}

Throughout the Southern states, the Harlequin Cabbage Bug is one of the best-known insects. It is called by many common names, due to its abundance and its conspicuous markings in red and black. It feeds freely upon a variety of plants, but is most destructive to cabbages. Its life history is very similar to that of the Squash Bug. The barrel-shaped eggs are laid in clusters, commonly in two rows of six eggs each. They soon hatch into small flattened bugs that bear a general resemblance to the adults, although, of course, they have neither wings nor wing pads. These young nymphs suck the sap from the leaves through their pointed beaks, and during the next month shed their skins four or five times before they reach maturity. There are several broods every year, and the winter is commonly passed in the adult condition.

As the Harlequin Cabbage Bugs come from their winter quarters very early and are readily attracted to mustard, turnips, and other plants, it is generally practicable to use these as trap crops. By planting, for example, a few rows of mustard in the cabbage field, the bugs will be attracted to these plants and may be readily destroyed together with the plants by spraying with pure kerosene. The field will then be comparatively free from the pest, and those that come later may be subdued by hand picking.

\section{Cicadas or Harvest Flies}

The Harvest Flies or Cicadas (Cicadidx) are the largest insects belonging to the suborder Homoptera. Every one has heard during the hot days of midsummer and early 
autumn, the strange, shrill noise of the common Harvest Fly, or Dog-day Cicada. This insect is present everywhere, and its curious song is one of the most striking and characteristic of summer sounds.

The most famous member of this family, however, is the strangely interesting Periodical Cicada or Seventeen-year Locust. The adults of these insects appear in certain localities at intervals of either thirteen or seventeen years. They may then be exceedingly numerous. At such times they deposit eggs in the twigs of trees. These eggs soon hatch into strange little larvæ that drop to the ground and work their way through the soil until they find some roots of trees or shrubs. Here they remain feeding and growing very slowly for a long period of years. As already indicated, in some regions they complete their development in thirteen years and in others in seventeen years. By the end of this long time, the little larvæ have become quite large, and are of the shape shown in the lower illustration on the next page. They now come to the surface of the soil and crawl up the trunk of some tree or shrub, where they emerge as adult cicadas. These are able to make a curious shrill noise, somewhat similar to that of the Dogday Cicada, although in both species the ability to sing is confined to the males. When the insects are very abundant, the sound may become almost deafening.

\section{LEAF HOPPERS}

If with a close-meshed insect net, you sweep diligently a few yards of meadow or pasture land, it is probable that the most abundant insects you find in the net will be the small, flattened, quick-jumping Leaf Hoppers (Jassoidea). These insects vie with the plant lice in their enormous numbers. They are likely to be present in any region. 


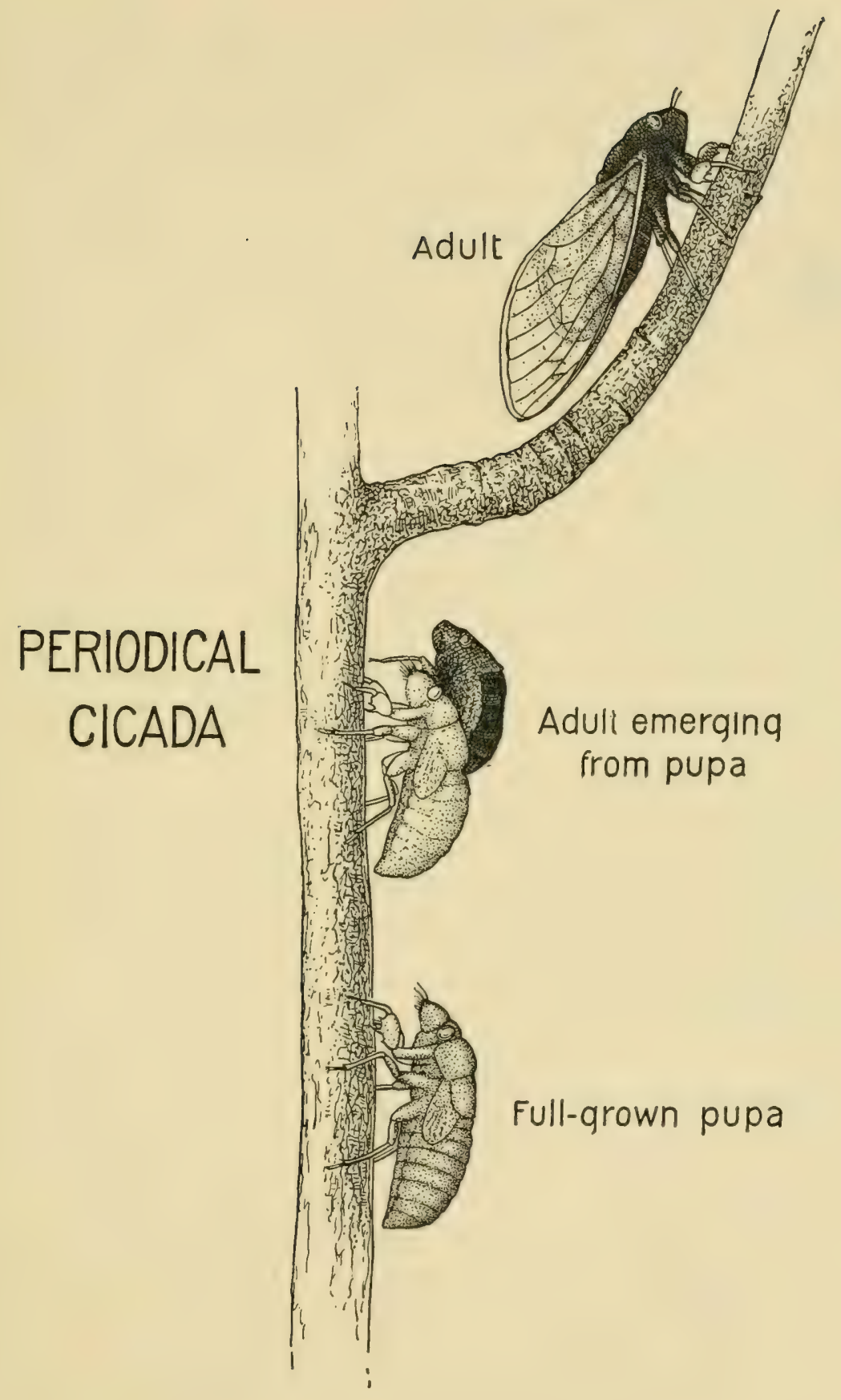


So many of them, however, live concealed in grass lands that most people have little knowledge of their abundance. They are nearly all quite small insects, but doubtless do a great deal more damage than is commonly attributed to them. They suck the sap from practically all kinds of

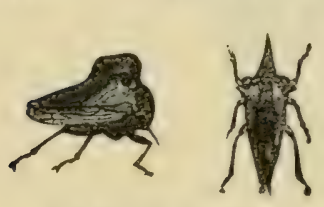

TREE HUPPERS grains and grasses, and many infest trees, shrubs, and other plants. They are closely related to the Tree Hoppers found on the twigs of trees.

The life history of many species of the grass-feeding Leaf Hoppers has been carefully studied. The eggs are laid in autumn in the grass blades and remain unhatched through the winter. In spring they hatch into tiny nymphs or larva that suck the sap from new grass blades and gradually develop into adult Leaf Hoppers. During this process they generally molt or cast their skins four or five times, reaching maturity early in summer. There seem generally to be at least two broods of the grassfeeding Leaf Hoppers in a season.

In cases of great injury by these grass-feeding Leaf Hoppers, it may be worth while to burn over the areas most badly infested in winter or early spring, and thus destroy the winter eggs. It has also been found that vast numbers of the adult insects may be killed by the use of a broad pan similar to the hopper-dozer often employed to destroy grasshoppers. If this pan is covered with kerosene, tar, or some similar substance, the insects will be caught and killed.

Many crop pests are found among the Leaf Hoppers that feed upon vines, shrubs, and trees. The Grape Leaf Hopper is one of the most destructive and widely distributed of these. Its life history has been carefully worked out in New York, where it has been found that the adult 
insects spend the winter under leaves and rubbish, or in some similar shelter. They come forth rather early in the spring and feed for two or three weeks upon the leaves of raspberries, strawberries, and other plants. Early in May, when the leaves of the grapes appear, these adult Leaf Hoppers fly to the vineyards and attack the developing foliage. They continue here for many weeks. The females deposit their small, whitish eggs in the green tissues of the blades of the leaves, several eggs being inserted side by side.

A fortnight later these eggs hatch into small larvæ or nymphs that also suck the sap from the leaves and gradually develop, passing through five molts before they become mature. These young nymphs are able to run over the surface of the leaves, but they do not jump as do the fully developed Leaf Hoppers. They reach maturity during the latter part of the summer and continue present until October, when they seek shelter for the winter. There is thus normally but one brood in a year, although in more southern regions there are probably two broods.

The most effective means of combating this insect are burning over the places of hibernation, destroying the nymphs with a solution of whale-oil soap at the rate of one pound to ten gallons of water, and trapping the adults upon sticky shields held temporarily beside the vines.

The Apple-tree Leaf Hopper is another widely distributed destructive species. Examples of this may be found on the under side of apple leaves at almost any time during the season. The Rose Leaf Hopper is another form that may practically always be found upon rosebushes, where the characteristic result of Leaf Hoppers' injury may be seen in the whitened spots on the upper surface of the leaf. 


\section{Jumping Plant Lice}

The Jumping Plant Lice (Psyllidæ) are few in number of species, and with the exception of the Pear Psylla are of comparatively little economic importance. This Pear Psylla, however, often becomes a very serious pest, attacking pear trees in overwhelming numbers, and sucking out the sap to such an extent as to cause great injury. The adult insect, which is only about the size of an ordinary plant louse, passes the winter on the bark of pear trees, commonly more or less concealed within crevices. They deposit their eggs very early in spring, especially about the buds or upon the unfolding leaves. In two weeks or so, the eggs hatch into tiny larvæ which attack the petioles of the leaves as well as their general surface. In about a month each larva reaches maturity, having molted five times during the process. There are several broods each year, the number doubtless varying with the locality.

Like the aphicles, these insects secrete a large amount of the so-called honey dew, which consists chiefly of the sap of the plant that has passed through the bodies of the insects. Where a pear tree is badiy infested, this honey dew covers the leaves, often collecting in large drops, which are believed to act sometimes as lenses in condensing the sun's rays so as to burn the foliage beneath. Upon this honey dew, there also develops a black fungus that soon gives the leaves and fruit of the infested tree a strange blackened appearance.

\section{Scale Insects or Coccids}

The strange Scale Insects or Coccids (Coccidæ) form one of the most important groups of the Homoptera. Many of these are commonly known as Bark Lice, because they 
are found so frequently upon the bark of trees. If you examine the twigs or leafy branches of some apple trees, you will probably find what look like miniature oyster shells upon the bark. These are examples of the Oyster-shell Scale. If you will carefully pry up one of these tiny scales and look at its under side with a lens, you will probably find a large number of minute oval eggs. Early in summer, these eggs hatch into tiny insects that wander over the surface of the young bark. In a day or two, they fix themselves in one place by inserting their beaks into the tissues and sucking out the sap, where they remain and gradually develop their scaly covering.

One of the most destructive insects ever introduced into America belongs to this family. It is the notorious San José Scale, a pest that during recent years has attracted more attention from fruit growers than any other insect.

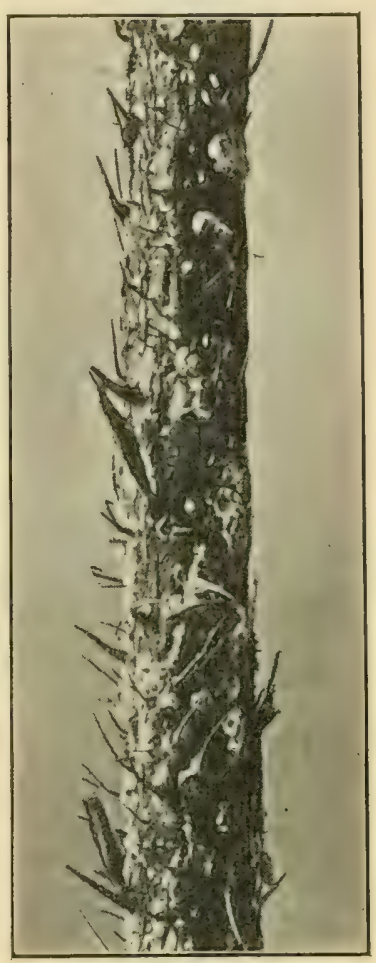

SCALE INSECTS ON ROSE It is especially dangerous because its presence is difficult to detect until it becomes sufficiently abundant to injure or kill the infested tree. It then appears as a curious scaly crust on the bark. When only a few are present, they are difficult to find, as they are simply small circular spots of much the same color as the bark, plainly seen only through a magnifying glass.

The appearance of the individual scales is well shown in the pictures on the next page. Each scale is a small circular object, closely attached to the bark, not more 


\section{Much Maqnified}

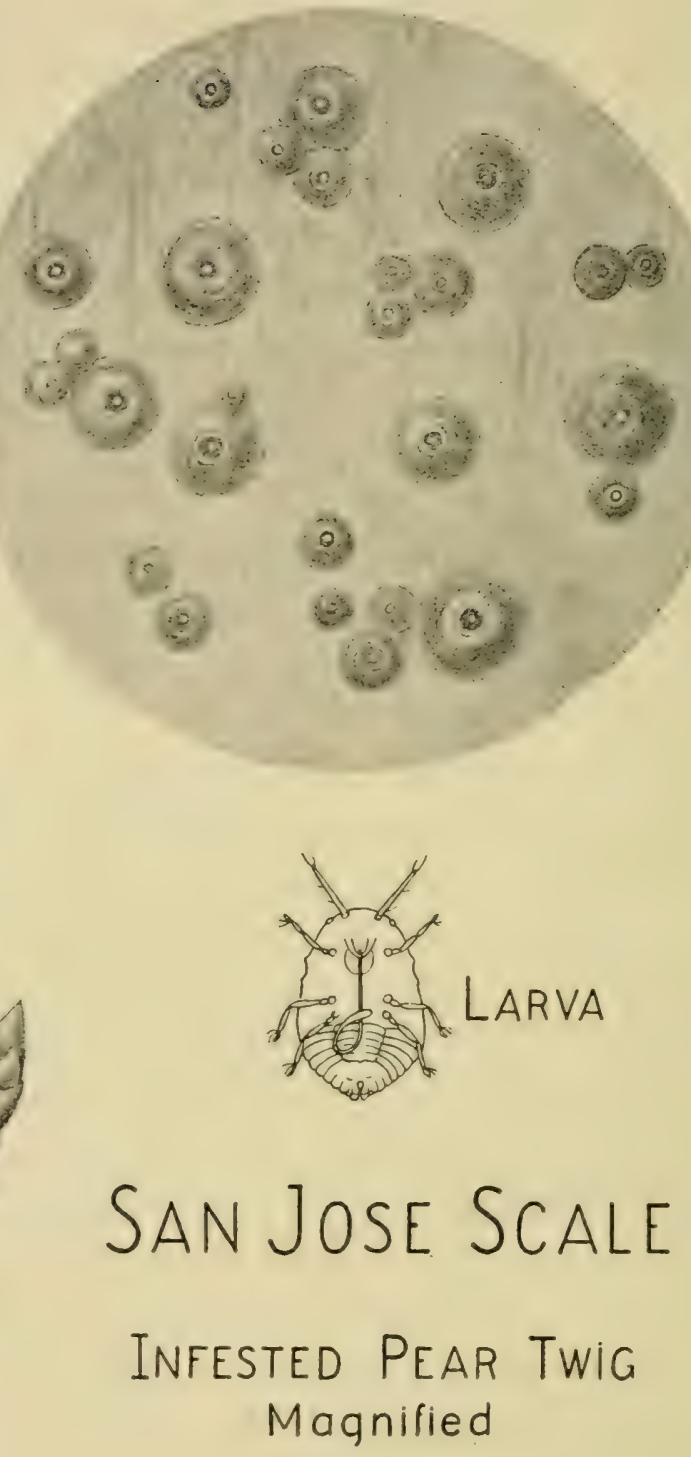


than one sixteenth of an inch in diameter, having a dark raised point near the center. At first these scales are likely to be scattered here and there over the bark, but as they increase in numbers, they are found nearer together, touching or overlapping one another. Finally, when they become very abundant, they make a thick scurfy layer, of a grayish color that obscures the natural color of the bark and is easily rubbed off with a knife. The presence of such a layer indicates that the sap from the bark is being sucked out by millions of the insects, and that the health of the tree is being seriously impaired.

The young scales that live through the winter develop in early spring into mature insects, and each of the females may give birth to about

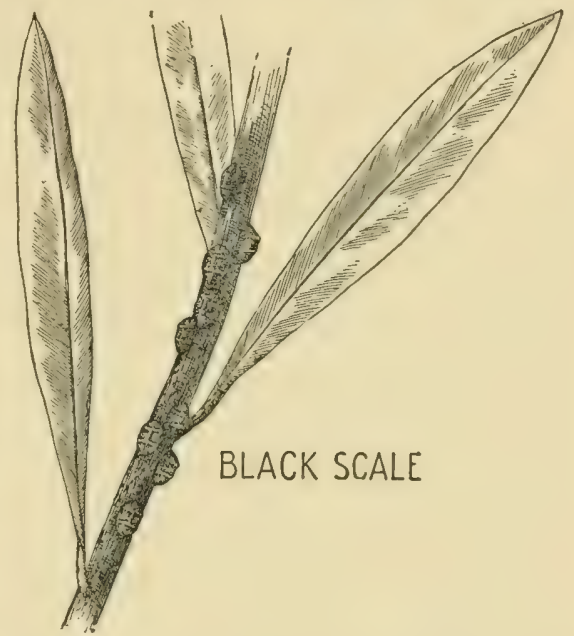
four hundred young. These are tiny yellow creatures that crawl around for about a day before they finally fasten themselves to the bark by inserting their curious beaks to suck the sap. They then begin to secrete the scale which is so characteristic of this family of insects. The scale is composed of white waxy threads secreted by the skin of the larvæ, which mat together to form a rather dense covering. This whitish scale turns gray or even almost black within a few days. The female scales are always wingless, but the male scales develop into active two-winged insects which are able to fly about.

When the San José Scale appears upon older trees, it is most likely to be found on twigs and smaller limbs, but 
upon young trees it may occur over the whole surface of the bark. It does not confine its attacks to the bark, however, for leaves and fruit are often infested. Upon these, as well as upon young bark, there is frequently a very characteristic purplish ring around each scale. When the leaves are infested, the insects are especially likely to be found along the midrib.

This scale has commonly been introduced into new localities by means of young trees from nurseries. There are now rigid inspection laws in nearly all the states to prevent the further distribution of the pest in this way. The most effective remedy so far discovered, is that of spraying in late autumn with a miscible oil or a lime-sulphur wash. As is so often the case, the use of this lime-sulphur wash has been found to have additional advantages in destroying other insects and in preventing various fungous diseases.

The Cottony Maple Scale is one of the most distinctive members of the great family of Bark Lice. It may be found in vast numbers, especially in the Middle Western states, upon the twigs of the silver maple, and is easily recognized by the mass of cottony tufts which are found beneath each of the darker-colored scales. Early in summer great numbers of eggs are deposited inside of these cottony masses. About three thousand eggs commonly occur beneath each scale. In June or July these eggs hatch into tiny larva that wander over the leaves and soon fix themselves, inserting their beaks to suck the liquid from the tissues. Here they continue to develop until shortly before the time for the leaves to fall. By this time, the males mature into small winged insects that are able to desert the leaves and fly about. The females, however, crawl from the leaves to the bark of the neighboring twigs, 
upon which they fix themselves and secrete a larger scale. They remain on the twigs through the winter, and the following spring complete their growth, produce the cottony mass within which they lay their eggs, and finally die. There is thus but one brood each year. Fortunately this insect, as well as most other members of this family, is commonly kept in check by its parasitic and other enemies. The most important of these are small, black, four-winged chalcid flies and various species of ladybird beetles.

\section{The Aphides or Plant Lice}

From the point of view of their destructiveness, the Aphides or Plant Lice form one of the most important families, not only of the true bugs, but of all insects. During very recent years a single species affecting grain has caused a loss of more than a million dollars in one state in a single year. There are a great many species of these little pests, of which the Green Flies of house plants are familiar examples. They infest nearly all kinds of crops, sucking the sap through their pointed beaks and often causing enormous losses.

The life histories of the various species of Aphides are quite similar. A good illustration is found in that of the Spring-grain Aphis which has attracted much attention on account of its damage to grain crops. Pictures of its various stages much magnified are shown on the next page. In many localities, it has been known as the "Green Bug." It is especially abundant in the more southern rather than the far northern states.

Under normal conditions the Spring-grain Aphis passes the winter in the condition of the egg, attached to leaves or stalks of various grains and grasses. Early in the spring, these eggs hatch into small plant lice that suck the sap 
from the food plants and become full-grown in a very short time, possibly a week or ten days. All of these insects that thus hatch from the winter eggs are what are known as viviparous females, because they are able to give

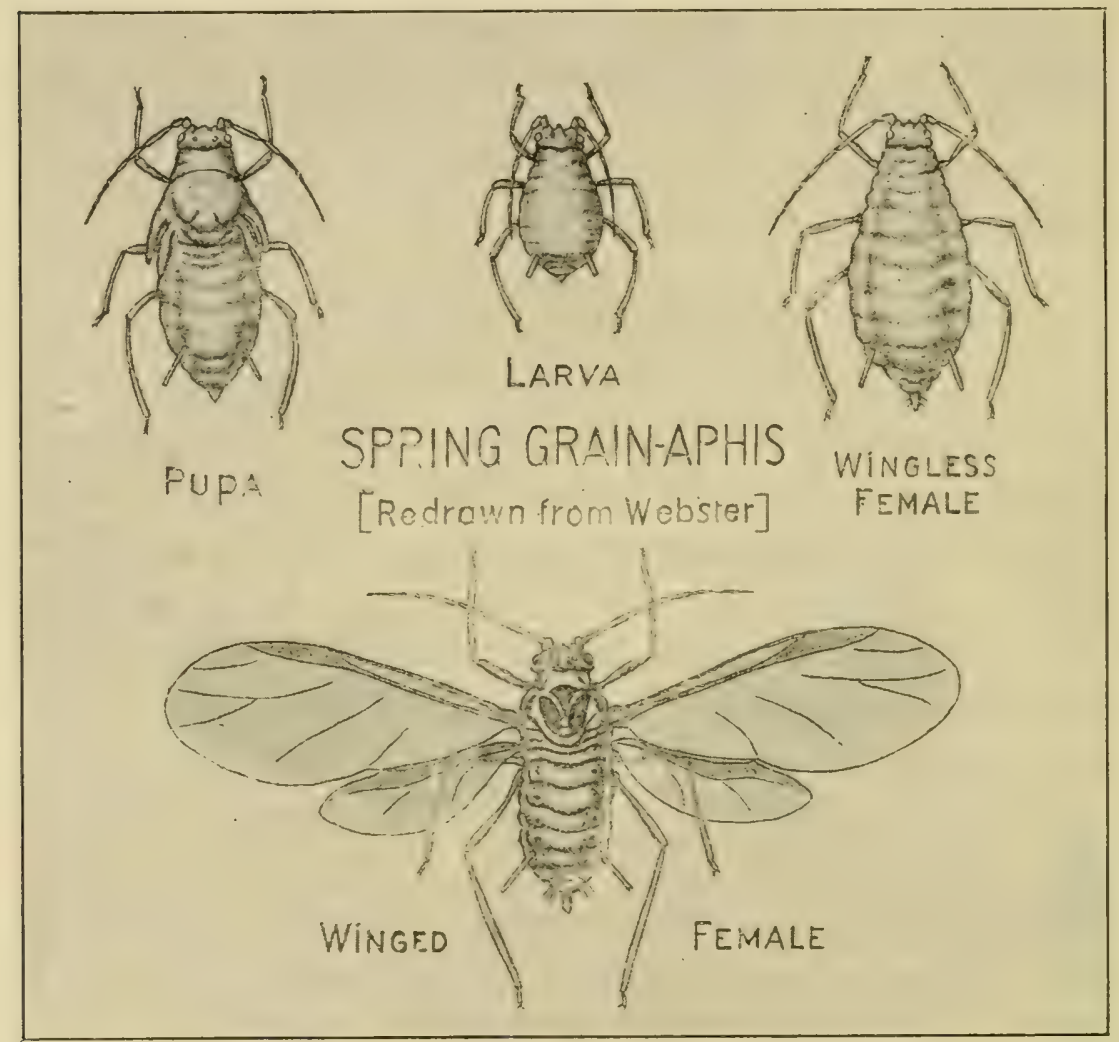

birth to living young. Each insect produces a large number of these young plant lice of the second generation, and these in turn very quickly mature and give birth to a third generation. This method of reproduction continues throughout the spring, summer, and early autumn. On account of the rapid growth and of the large number of young produced by each of the viviparous females, the insect is able to multiply with astounding rapidity.

When the food plant is green and succulent, nearly all 
the aphides are wingless forms, but when for any reason the condition of the food plant is less favorable to the development of the plant lice, large numbers of winged viviparous females are developed. These are often called winged migrants, because so many of them fly away to other fields where they settle upon new plants and there give birth to living young. In this way the insect commonly spreads from field to field, and when it has wintered in the South, it may gradually spread northward to infest new localities.

When the grain crop ripens, the aphides usually migrate to various kinds of grasses, where they continue to develop throughout the summer, and migrate back again in autumn to fields of young grain. In these fields they continue to reproduce in the same viviparous manner until the approach of cold weather. At this time a sexual generation is developed, the males commonly being winged, while the females are wingless. The winter eggs are laid by these females, and thus the yearly cycle is completed.

When the winters are mild, it very often happens that this Grain Aphis is able to continue to develop throughout the winter in its viviparous condition, so that in a given locality we may have it passing the winter both in the egg state and in that of various ages of viviparous females. It is under such conditions that the greatest damage is likely to occur, especially becalise of the fact that the insects are able to thrive and multiply in a lower temperature than is favorable to the development of the tiny parasitic flies that commonly keep them in check.

An even more interesting life history is that of a closely related plant louse known as the European Grain Aphis. This insect is abundant and very generally distributed in America. Its special point of interest is that it develops 
in summer on various grains and grasses, and migrates in autumn to apple trees, where the winter eggs are laid. Consequently, when we attempt to follow its history through the year, we may begin in early spring with these eggs upon the buds and bark of apple twigs, with this summary as a result:-

In early spring the eggs hatch into small aphides that crawl at once to the developing buds where they begin to suck the juices of the unfolding leaves. In a few days, this first generation from the egg, often called the stemmothers, begin giving birth to living young that also suck the sap from the leaves and soon become mature. In this way, four or five generations may develop on the apple in spring. A large proportion of the later generations are winged females, which fly away to settle upon grasses and grains and start colonies upon these host plants. Consequently these are called winged migrants. As a rule, all of the plant lice of this species thus desert the apple before midsummer.

The winged migrants upon grains and grasses establish colonies that continue to increase throughout the remainder of the summer upon these food plants, one generation following another in rapid succession. Rather early in autumn, however, a generation of winged females, called the return migrants, is developed from the grain and grassfeeding colonies. These return to the apple, where they give birth to a generation of wingless egg-laying aphides, by which the winter eggs are laid upon twigs.

There are various other species of aphides which may be found upon the leaves of the apple. The presence of these other species has rendered the working out of the life history of this European Grain Aphis a much more difficult problem than might at first appear. 
It was formerly supposed that to a large extent each kind of plant was subject to attack by a special kind of plant louse, but after careful studies were made of the structure and life histories of the plant lice, it was found that very often a single species of the insects may attack several species of plants. One of the most striking examples of this ability to live upon various host plants is that of the Melon Aphis, which infests an extraordinary variety of host plants. These include vegetable, field, and fruit crops, as well as many cultivated flowers and an extraordinary number of weeds and other wild plants. It has been known by such common names as Cotton Aphis, Orange Aphis, and Dock Aphis. It is so commonly destructive to melons, cucumbers, and related plants that it is now generally called the

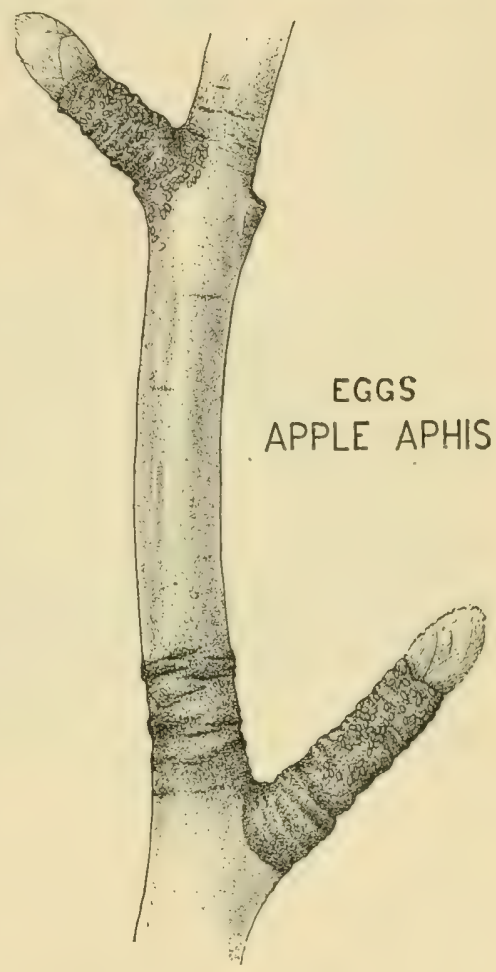
Melon Aphis, although in cotton-growing regions it is known as the Cotton Aphis.

The life history of this insect is not very different from that of the Spring-grain Aphis already described. The winter is passed both in the egg state and in that of the viviparous females. Reproduction begins early in spring and continues throughout the season, the insects multiplying with marvelous rapidity and migrating from time to time from one food plant to another. The ability of the species to develop upon so great a variety of hosts renders it 
easy for the migrating females to find suitable food, and it also renders the pest very difficult to fight successfully.

\section{Ants And Aphides}

One of the most interesting things about the aphides is their relation to various kinds of ants. If you look at a colony of plant lice upon almost any tree or shrub, you will probably find at least one kind of ant wandering around among the aphides, and very likely you will find a regular

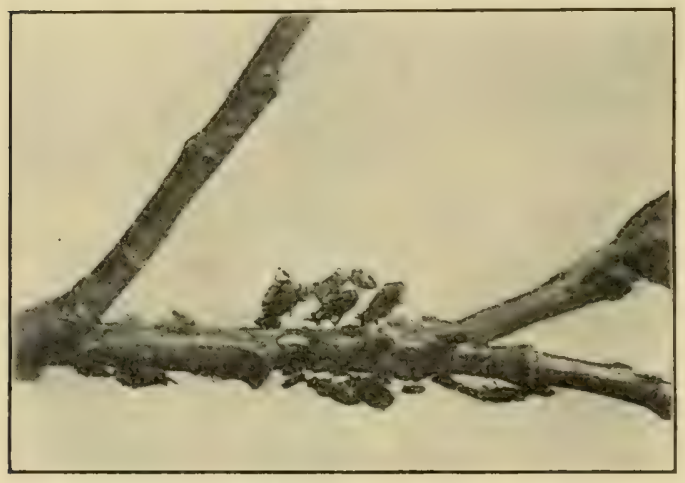

ANT attenidng Aphines upon a Willow TwIG

procession of ants going up and down the trunk of the tree or shrub. If you watch one of these ants carefully, you will probably see it find a plant louse, touch it with the feelers or antennæ and very likely lap up a drop of liquid exuded by the aphis, for these ants visit the plant lice to obtain the liquids that pass through their bodies. In consequence, the plant lice are sometimes referred to as the milch cows of the ants.

There are many strange and interesting things to be found out concerning the relations of the ants and the aphides. To a very large extent, many species of aphides find friendly helpers in the ants. One of the most interesting examples of this is the case of the Corn-root Aphis, an insect often very destructive to corn crops in the Mississippi Valley.

This Corn-root Aphis is constantly attended by a small brown ant that burrows out tunnels along the corn roots in order that the plant lice may have a place to live. As the 
numbers of the plant lice increase, the ants extend the burrows to provide for them. The ants continue thus to look after the needs of the aphides throughout the summer months. In autumn, however, a still more interesting thing takes place, for at this time an egg-laying brood of aphides is developed and the small blackish eggs are taken by the ants far down in their underground nests, where the eggs are cared for throughout the winter. When the eggs hatch early the following spring, the young plant lice are carried by the ants, generally to the roots of some grass-like weed, there to start the new season's brood, which will be transferred later to the roots of the young corn plants.

In a case like that of the Cornroot Aphis, where the eggs of the insect pass the winter in the cornfield, rotation of crops is the best means of reducing injury by the pest. It is fortunate that there are great numbers of enemies of aphides in general, for otherwise it would probably be impossible to grow many crops now produced. Many birds feed freely upon the eggs and later stages of aphides, while vast numbers of predaceous and parasitic insects develop at their expense. The insecticides that are most effective in destroying plant lice are kerosene emulsion, whale-oil soap, and various decoctions and extracts from tobacco stems.

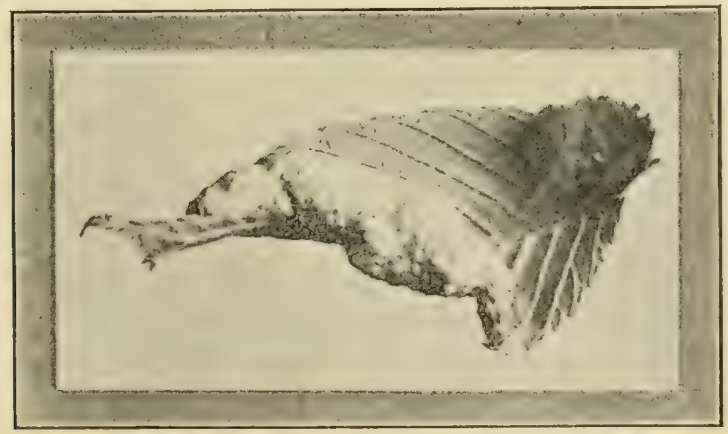

ELM LEAF AFFECTED BY APHIDES 


\section{OBSERVATIONS FOR PUPILS}

\section{Squash Bug}

I. To what extent are these insects troublesome in your locality?

2. What plants do they attack?

3. What methods are used to kill them?

4. Try placing shingles or small boards about the hills to see if the bugs seek their shelter at night.

5. Make a drawing of the Squash Bug for your insect booklet.

Read : -

'The Common Squash Bug, U. S. Bureau of Entomology, Circular 39.

\section{Harlequin Cabbage Bug}

I. Is this insect common in your region?

2. What plants have you known it to feed upon?

3. Have you seen the eggs? Where were they laid?

4. What remedies have you known to be used against Harlequin Cabbage Bugs?

\section{Cicadas or Harvest Flies}

I. Have your ever known an outbreak of the Periodical Cicada? If not, ask your friends about such outbreaks.

2. Do you know the song of the common cicada? How often do you hear it? Is it more likely to be heard on hot or cool days? Did you ever see one of the cicadas on a tree?

3. Read some of these accounts of cicadas:-

American Insects, pages I66-168. Stories of Insect Life, Second Series, pages I-5.

\section{LEAF HOPPERS}

I. Look on the under sides of the leaves of trees, shrubs, and herbs to find leaf hoppers. Are they of different sizes and colors? You can get many of them by sweeping grasses and herbage with an insect net or by beating branches over an open inverted umbrella.

2. You will readily find the earlier stages of the leaf hoppers on many leaves. Are the wings developed? Can the young hoppers jump like the adults? 


\section{BARK Lice or SCALE Insects}

I. Look on apple twigs for the characteristic scales of the Oystershell Scale. Pry up a scale and look on the under side with a lens. In the fall, winter, or early spring you are likely to find many eggs.

2. Examine various fruit trees, especially peaches, plums, and pears, for the San José Scale. If found, learn whether the trees have been sprayed to destroy them. In autumn the scales are likely to be found upon the fruits.

3. Examine other trees and shrubs for other scale insects. In order to learn their names, send such as you find to the Bureau of Entomology, U.S. Department of Agriculture, Washington, D.C., with a letter telling on what plant you found them.

\section{Aphides or Plant Lice}

I. You generally can find these insects with very little trouble. Look on the leaves of apple or other fruit trees, or on willows or other trees. Look also on the leaves of flowers and vegetables. Do all the different kinds of aphides you find look alike?

2. In fall and winter look on the bark of the willow branches and about the buds of apple trees to find the winter eggs of the

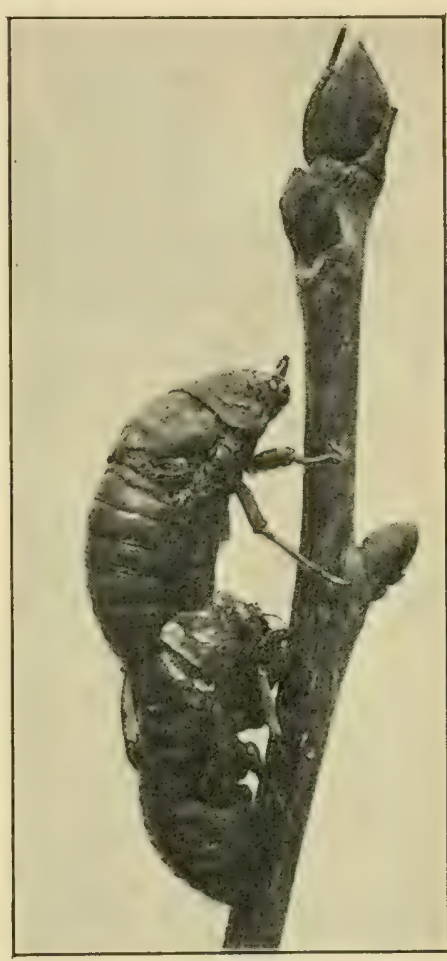

CICADA EMERGING FROM NYMPH SKIN aphides. Examine them through a lens and make a sketch for your insect booklet.

3. Many aphides live in gall-like modifications of the leaves. Make sketches of such of these as you can find.

4. Read one or more of these references : -

American Insects, pages I71-176. Life Histories of American Insects, pages 209-247. 


\section{CHAPTER VIII}

\section{The Butterfiies and Moths}

THE great order of insects to which the butterflies and moths belong is called Lepidoptera, a word meaning scalewinged. This name was given to the group because each of the beautiful wings with their varied colors and markings is composed of a thin membrane, to which are attached vast numbers of tiny scales over-

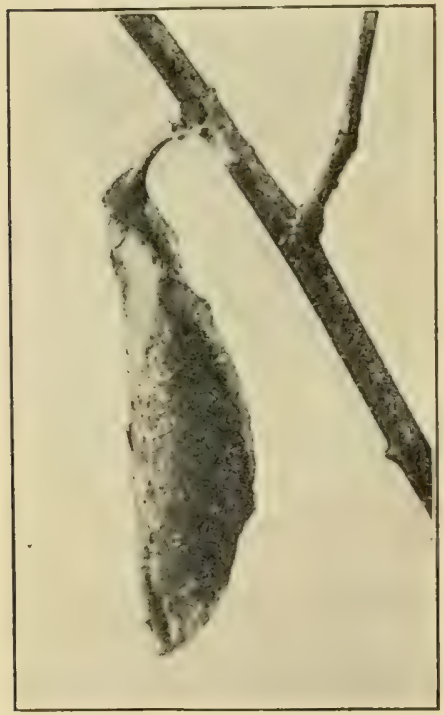

Promethea Moth CoCoON lapping one another, much like the shingles of a house. The insects of this order have sucking mouth parts and two pairs of wings. The transformations are complete. The period of growth and feeding is that of the larva or caterpillar, the adults eating only the nectar of flowers or similar substances, or, in some cases, taking no food at all.

This order includes a large number of species, varying greatly in size and habits. Some of the moths are so tiny as to be barely visible to the unaided eye, while others are so large and conspicuous as to attract attention at considerable distances. By far the largest proportion of the species feed in the larval state upon the tissues of plants, and consequently a great many injurious insects are found in the order. 


\section{The Butterflies}

The highest group of the Lepidoptera is the great superfamily to which the butterflies belong; this is commonly called the Papilionina. This includes four distinct families which need not be considered specifically here.

The butterflies as a group are day-flying insects, with knobbed antenna or "feelers," small bodies, and comparatively large wings. The caterpillars do not spin cocoons, changing to the pupa state as naked chrysalids, although often there is a loop of silk over the shoulders to hold the chrysalis in position. These caterpillars have three pairs of true legs and five pairs of prolegs.

A familiar example of the life history of a butterfly is found in the common Cabbage Worm, the adult of which is the common white butterfly, with black spots upon the wings, which is to be seen flying about gardens throughout the summer. These butterflies lay eggs upon the cabbage leaves. The eggs soon hatch into small greenish larvæ that feed upon the tissues of the leaf for a few weeks, molting or casting their skins four or five times during this period. When full grown, they find some sheltering leaf, stone, or board, beneath which they change to the chrysalis state, to emerge a short time later as adult butterflies.

While as a group the butterflies have by no means as many injurious species as have the various groups of moths, a number of rather destructive insects belong to it. One of the most widespread of these is the Black Swallow-tail or Asterias Butterfly, the larvæ of which feed upon the leaves of celery, carrots, parsnips, and various other members of the parsley family. These caterpillars are green, marked with black, and may very commonly be found upon the garden plants mentioned. Another species, which is 
often destructive, is the Mourning Cloak Butterfly, the caterpillars of which frequently defoliate willow, poplar, and elm trees, so that in some localities they are called the Spiny Elm Caterpillars.

An even more generally destructive butterfly is the largest of our North American forms, called the Cresphontes Butterfly. This is a Southern species, being, however, widely distributed as far north as Massachusetts, New

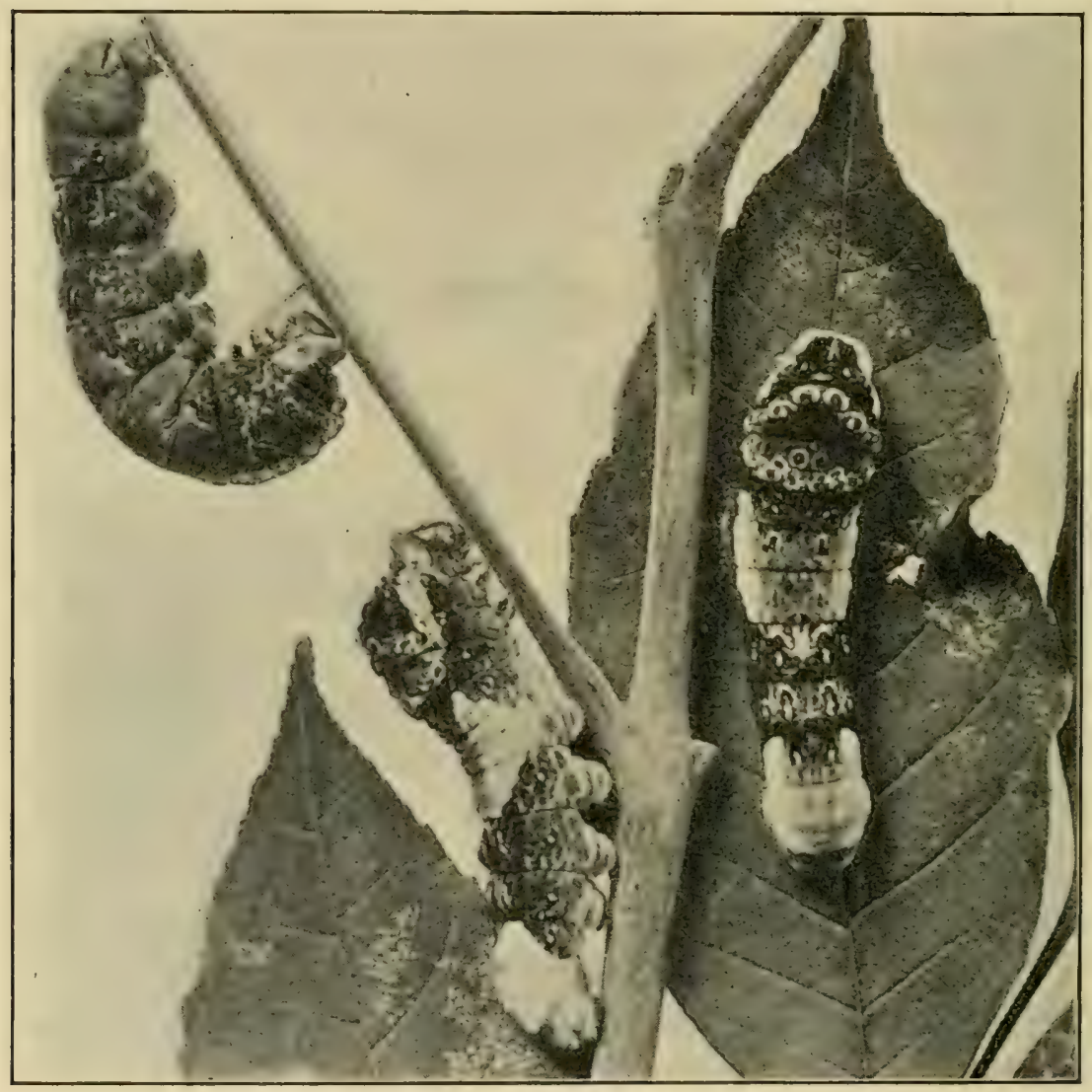

ORANGE-DOG CATERPILLARS

York, and Illinois. Throughout the orange-growing regions, the caterpillars are commonly known as "Orangedogs," because they feed so largely upon the leaves of 
orange trees, being especially destructive to young plants in the nursery. They are curious-looking caterpillars, and doubtless their unusual appearance, possibly suggestive of a watchdog, has given rise to the common name.

Briefly summarized, the life history of the Orange-dog Butterfly is this: The eggs are deposited singly upon the

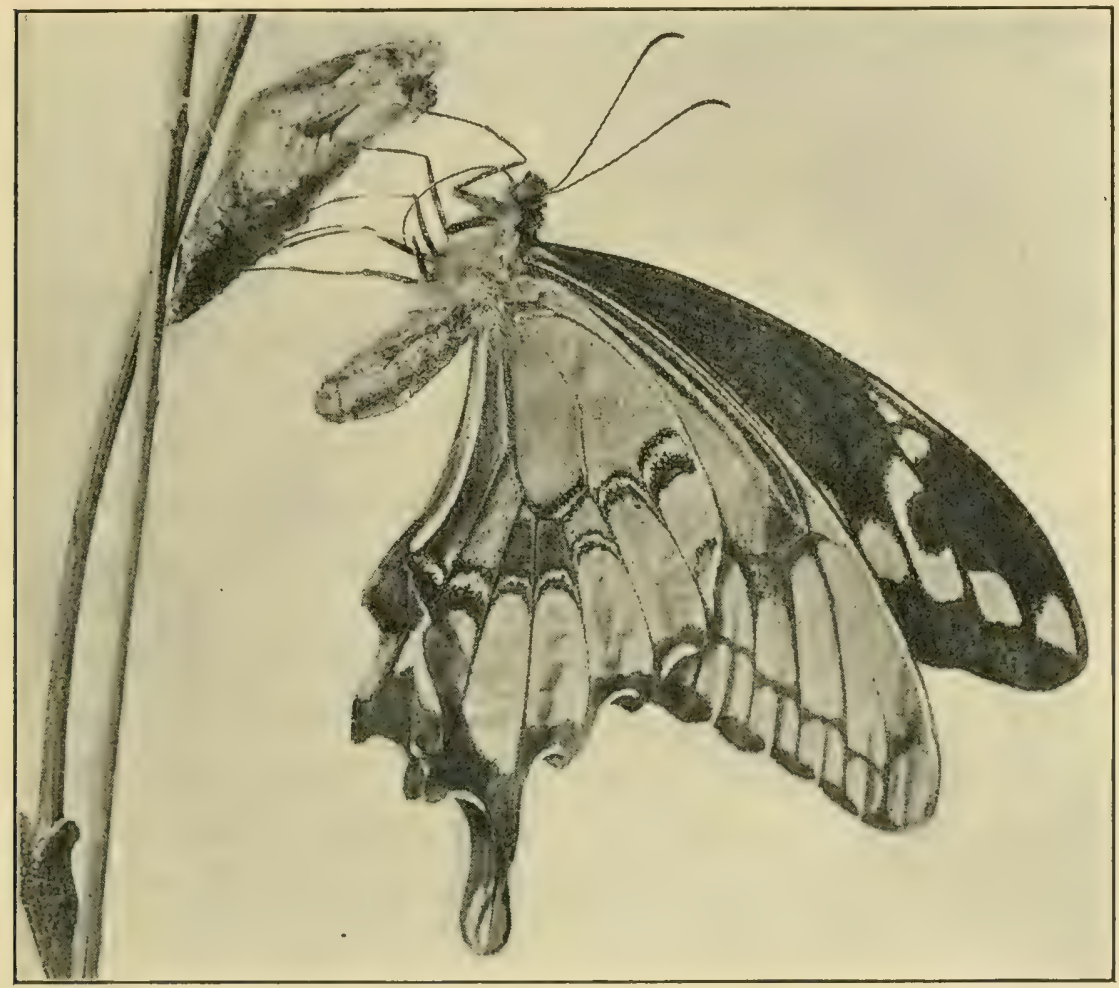

BUTTERFLY OF ORANGE-DOG CATERPILLAR JUST EMERGED FRUM CHRYSALIS

young growth of the orange, generally near the tips of leaves or branches. In a week or more they hatch into tiny caterpillars that feed upon the tender foliage. When not eating they rest upon the lower surface of the leaves. In about a week, they become too large for the skin with which they were born, and they molt or cast their skin, coming forth with a new one that had been formed beneath 
the old. They then feed again for a week or so before molting for the second time.

These processes of feeding and molting are commonly continued for four or five weeks, the caterpillars eating more and more of the leaves as they grow older. They no longer confine themselves to the succulent young leaves and shoots. A single insect may do much damage to a young tree, as it consumes a relatively large amount of the growing tissues of the plant. When full grown in the caterpillar stage, the insect changes to the chrysalis, generally attaching itself by silken threads to the bark of a tivig or branch of the orange tree. The chrysalis takes on the same general coloring as the surrounding bark, so that it becomes decidedly inconspicuous. In a little less than a fortnight it emerges as an adult butterfly.

Like the caterpillars of the other Swallow-tail Butterflies, these Orange-dogs have curious yellowish scent organs, which protrude from the upper surface just behind the head. When the caterpillar is disturbed, these give forth a very disagreeable odor, which is believed to serve as a means of repelling birds and possibly other enemies. At any rate, good observers have noticed that the insect is not molested by birds, although it is known to be subject to attack by various insect parasites. Each female butterfly, apparently, is able to deposit four or five hundred eggs, and one of the interesting ways suggested for preventing the injuries of the caterpillars is to shoot the butterflies upon the wing with cartridges loaded with sand or small bird shot.

\section{Sphinx Moths}

A beautiful family of the scale-winged insects is that of the Sphinx Moths or Sphingidx; these are commonly 
called Hawk Moths. They are characterized by having large bodies, with small wings and very long curious tongues, which sometimes reach a length of five or six inches. Nearly all of them fly just at twilight, rather than during the day. The family includes a large number of species, several of which are injurious to cultivated crops.

Most of the caterpillars of the Hawk Moths have the habit of assuming during the day a curious attitude, with the head end of the body held rigidly erect in a way suggestive of the famous Sphinx of Egypt. To this is doubtless due their common name of Sphinx Caterpillars. A familiar illustration of these larvæ may be found late in summer on tomato, potato, tobacco, and related plants, for the common tomato and tobacco worms belong to this group. There are really two species of these tomato worms, one being more abundant in the North, and the other in the South. When full grown the caterpillars burrow into the soil, where they change to brown pupæ, and early the following summer wriggle to the surface of the soil, to emerge as beautiful grayish Hawk Moths.

Another common, widely-distributed member of this family is the Pandorus Sphinx, the caterpillars of which are often injurious to grapevines and Virginia creepers or woodbines. The moth is large and beautiful, exquisitely colored in greens and browns. The eggs are laid early in summer upon the leaves of the food plant, hatching in a few days into small sphinx caterpillars that feed and molt for several weeks before becoming full grown. They are then three or four inches long, and the thickness of a man's finger. They now crawl to the ground and burrow into the soil a short distance, where they change to pupæ, to remain until the following season, when they emerge as moths. 


\section{SiLK-SPINNING Moths}

One of the most important groups of the Lepidoptera is that of the silk-spinning moths (Bombycinæe), of which the most famous is the silkworm of commerce. As a rule, the bodies of the Bombycine Moths are large and thick, and the mouth parts are generally inconspicuous or absent altogether. In the latter case the adult moth is unable to take any food, consequently these moths are seldom to be seen visiting flowers, as do the Hawk Moths and the Owlet Moths. The caterpiliars are frequently thickly clothed with hairs, and they nearly always change to pupie within

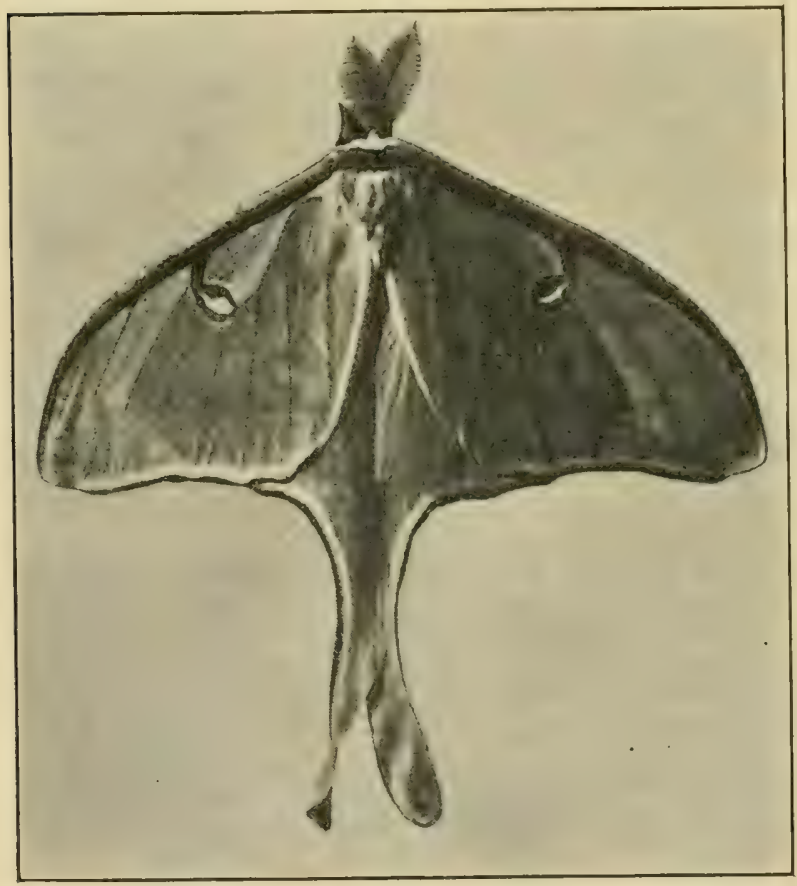

Luna Moth: Reduced the protection of silken cocoons. The families of this group include some of the insects most destructive to vegetation.

The most beautiful American insects are the larger forms of the Bombycine Moths. The wonderful translucent beauty of the Luna Moth, the handsome coloring of the Cecropia Moth, and the glorious browns of the Polyphemus Moth deservedly attract the attention of every one that sees 
them. The curious cocoons of the Promethea Moth fastened so securely to the branches of many trees and shrubs may be found throughout the winter over a large part of North America, and, if brought indoors, will yield a harvest of attractive moths in early summer.

The familiar Tent Caterpillar, the nests of which are to be found in so many wild cherry and apple trees during May and June, is also a smaller example of one of these families of silk spinners. These Tent Caterpillars are very easily reared indoors, so that it is easy to watch them spin their cocoons,

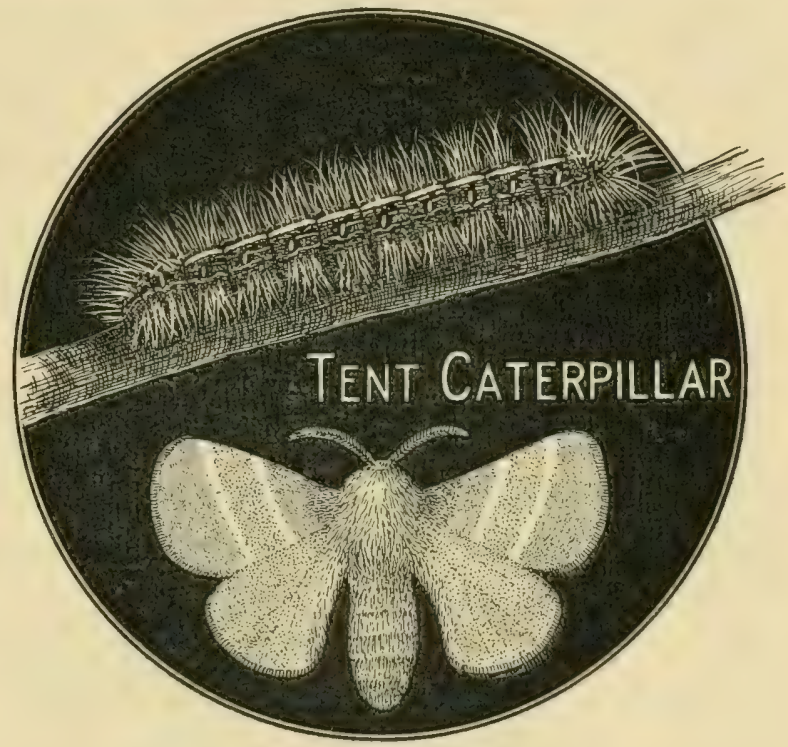
change to pupa, and emerge later as rather small brown moths.

The most notorious member of the nearly related family of Tussock Moths is the destructive Gypsy Moth, which during the last few years has done enormous damage in New England, and millions of dollars have been spent in fighting it. This Gypsy Moth is a native of Europe and was introduced into America about I869. Since then it has gradually spread from the Massachusetts town where it first escaped, and threatens to become one of the most widespread and destructive of insect pests. It is very desirable that people everywhere should be on the watch 
for it, so that on its first appearance in a new locality it may be promptly exterminated.

The adult Gypsy Moths appear upon the wing during the latter part of summer. The females are larger than the males, having a wing expanse of nearly three inches, and are of a whitish color. Their bodies are very large and heavy, so that the moth is able to fly only to a very slight extent. The male moths have a wing expanse of less than two inches, and are of a brownish-yellow color. Their bodies are slender, and the moths are able to fly readily.

Soon after emerging from the cocoons, the female moths deposit their eggs in characteristic masses, each mass commonly containing about five hundred eggs. They are very likely to be deposited in such hiding places as hollow trees or $\operatorname{logs}$, or among the stones of stone walls. These eggs remain unhatched until about the time the leaves begin to
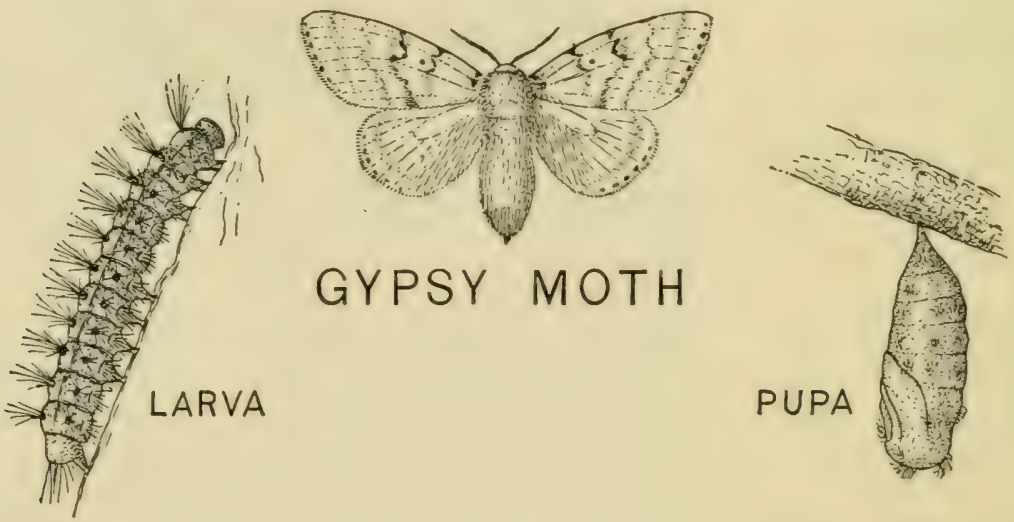

appear the following spring. Then they hatch into tiny caterpillars that feed upon the leaves. These grow rapidly, molting several times as the weeks go by, until finally they become full-grown hairy caterpillars that change to pupx within very slight silken cocoons, if, indeed, the few silken 
threads that commonly protect them may be called cocoons at all. A short time later they change again to adult moths.

The special canger from these Gypsy Moths is due to the fact that they multiply so rapidly, feed so ravenously, and attack practically all kinds of growing plants, including even the coniferous evergreens. They are as yet comparatively little injured by birds or parasitic enemies, although every effort is being made by official entomologists to introduce into this country the various parasites that keep the species in check in Europe.

The Fall Web-worm is a caterpillar easily found during late summer and early autumn. Its unsightly nests occur upon a great variety of fruit and shade trees. These Webworms hatch from eggs laid in clusters upon the leaves by a whitish moth. The tiny caterpillars begin to spin a protective web as soon as hatched. When very young they are yellowish, marked with black, and have a few hairs projecting from their bodies. They spin webs over the nearer leaves and then feed upon their green substance, eating this out so that the network of veins is left. As the days go by, they enlarge the web to cover other leaves, which are in turn attacked. They molt about once a week, remaining always beneath the protecting web. As they become full grown, the caterpillars eat more or less of the veins along with the leaf substance, but they generally avoid the midribs.

The full-grown Web-worm caterpillars are a little more than an inch long, with the body densely clothed with yellowish hairs. They now leave the trees and descend to the ground. There they spin slight silken cocoons within which they change to the chrysalis state, and remain until the following June, when they emerge as moths to lay eggs 
for another brood of Web-worms. There is thus but a single generation in a season.

One of the most destructive moths that has ever appeared in America is the famous Brown-tail Moth, which has already done an enormous injury in New England, and which threatens to become widely distributed over the country. This pest seems to have been accidentally introduced with a shipment of nursery stock from Europe. It is especially troublesome not only because the caterpillars feed upon practically all kinds of deciduous trees, but also because their bodies are covered with poisonous hairs that cause great suffering when they get upon the human skin.

The Brown-tail Moth passes the winter in characteristic nests composed of compact masses of leaves fastened together by silken webs. Inside each of these nests, there are commonly several hundred tiny caterpillars. When spring comes, these little caterpillars leave the nests when they wish to feed, crawling along the twigs until they reach foliage. At first they return to the nests at night and when not feeding, but as they grow larger, they are likely to desert them altogether. They continue to feed and grow until about the middle of June. Each caterpillar then spins around itself a silken cocoon, which is attached to some convenient shelter, commonly the leaves of the food tree. Inside these cocoons, the caterpillars change to chrysalids, and three or four weeks later again change to the peculiar whitish moths, with a tuft of brown hairs at the end of the body of the females. This tuft gives the insect its common name.

These moths appear in June, and lay eggs in clusters of two or three hundred each on the leaves, generally near the ends of the branches. During the latter part of the summer these eggs hatch into small caterpillars, which 
feed upon the leaves, forming gradually the protective nest that remains upon the trees through the winter. The caterpillars remain inside the webbed leaves, and thus wait until the following spring.

An effective remedy for this insect is that of burning the winter nests. In localities where it is not yet found, a constant watch should be kept for it, and any suspiciouslooking nests should be sent to the State Experiment Station for examination.

\section{Owlet Moths}

Another important family of the Lepidoptera is that of the Owlet Moths, or the Night-flying Moths (Noctuidæ). These are comparatively small moths, having thick bodies, slender antennæ, rather small wings, and for the most part inconspicuous colors. The larve are generally smooth-bodied worms, that commonly transform into papa in earthen cells. This group includes a large number of very destructive insects, of which the Army Worm and the Cutworms are good examples.

For more than a hundred years, the Army Worm has been destructive to American crops. It is one of those insects which appear at irregular intervals in enormous numbers, and then suddenly disappear for many years. Briefly told, the story of the life of the individual Army Worm is this :-

On some summer night there appears flying about a meadow, a rather large, light-brown moth. She finds a cluster of grass blades. Into the folded leaves of one or more of these, she pushes a number of small, whitish eggs, grouping them in rows of a dozen or more. A week or ten days later, each egg hatches into a minute whitish worm, that nibbles at the grass blades at night, and during 
the day hides beneath the grass from the rays of the sweltering sun.

This larva grows rapidly in size. At the end of a week it molts or casts its skin, a process in

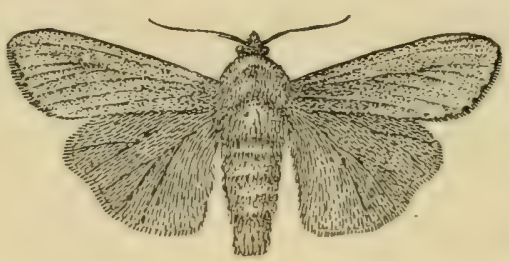

MOTH

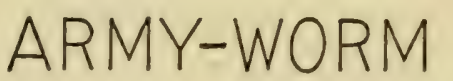

LARVA

which the old skin splits open along the back, and the worm crawls outclothed in a new skin that has developed beneath the old one. Again it feeds as before, its voracity increasing with its size. This molting is repeated four or five times during the month after the eggs hatch, so

PUPA

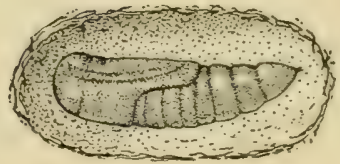
that by the end of this period, the insect is one and a half inches long, and has the brown

markings of the full-grown Army Worm.

The instinct of the caterpillar now teaches it to seek more secure shelter for the helpless stage, upon which it is about to enter. It burrows into the soil an inch or less and wriggles about in the earth until it produces a hollow cell. In this it casts its skin again and becomes a pupa - the third stage of its existence. When 
the caterpillars are very abundant, many of them do not go into the ground, but change to pupæ beneath whatever shelter may be at hand. About a fortnight later, another change takes place, and the fully developed moth emerges from the pupa, thus completing the cycle of the insect's life. The moths fly toward dusk and at night, and by means of their long tongues, coiled up when not in use, they suck the nectar of various flowers.

During ordinary years the Army Worm is present in most of the regions where its outbreaks occur, individual caterpillars feeding in meadows and pasture lands, but the number is not sufficient to attract notice. At such times, their habits of life are very similar to those of the common Cutworm, to which, indeed, the Army Worm is closely related. It is only when the caterpillars become so numerous that they exhaust the food supply of the field in which they develop, that the "army" habit is assumed. Then, however, they are forced to seek new quarters for food, and as their only mode of progress is by crawling along the ground, they move in solid masses toward adjacent fields. They feed preferably upon the various grasses and grains, although, when driven by hunger, they will eat the leaves of clover and other plants.

One of the most effective means of preventing the injuries of these armies of caterpillars is to dig a deep ditch or trench, into which the worms fall in great numbers, where they can be destroyed by various mechanical devices.

The Cutworms form one of the most vexatious groups of injurious insects. They are the smooth-skinned, thickbodied worms, an inch or so in length, which are so often to be found by careful digging about a tomato or cabbage plant that has been cut off in the night. They attack a great variety of crops and often cause serious losses. 
The Cutworms are the young or larvæ of rather large millers, or night-flying moths of the family Noctuidæ. One of them is represented natural size in the figure below. In the case of several of our common species - for there

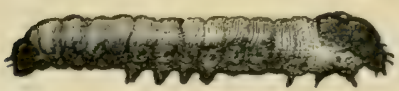

CUTWORM LARYA

are many different kinds of Cutworms — these moths lay eggs in grass lands late in summer or early in autumn. The eggs soon hatch into small worms that feed upon the grass until cold weather, when they seek such shelter as can be found in the soil or rubbish at or near the surface of the soil, and remain quiet until spring. They are likely to be half grown when winter closes in.

When the sunny days of April come, the Cutworms again begin to feed. If the grass land has been plowed, they eat such green things as they can find, until the corn or other crop comes up; then they feed upon it. If they are in grass near gardens, they are likely to wander over the garden more or less, taking such plants as they find. They travel at night, remaining concealed in or near the soil during the day.

Toward the latter part of the spring the Cutworms become full grown in this larval state. They then burrow into the soil, and change to pupre or chrysalids of a brownish color. About two weeks later they again change to adult moths.

Various remedies for Cutworms are known. In gardens, when a plant has been cut off, a prompt search of the soil about the base of the stem will generally reveal the worm, which may then be killed. On a larger scale, the use of a poisoned bait made by mixing a small amount of Paris green with bran or middlings, or a mixture of the two, has been successful. This is scattered upon the grass beside the field to be protected, or is placed in rows in the field 
itself. But great care is of course necessary in such use of poisons.

It is not often that an insect attacks three crops which are so different in every way as cotton, corn, and tomatoes. This is the case, however, with the noctuid moth, known by the various names of Bollworm, Corn Worm, and Tomato Fruit Worm. The caterpillars have a general resemblance to some of the commoner cutworms, although they vary greatly in color and markings. In the Southern states, these caterpillars feed to a destructive extent upon the bolls of cotton, on account of which they are called Bollworms. In regions farther north, these caterpillars feed inside the husks of green corn, upon the tassels and immature kernels, on account of which they are commonly called Corn Worms or Tassel Worms.

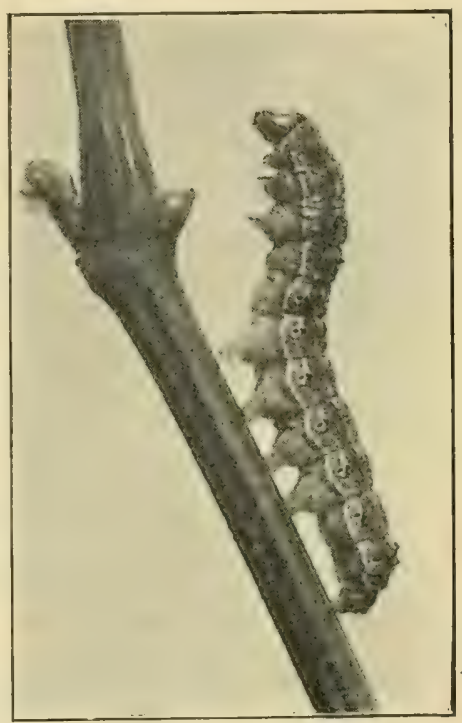

COTTON BOLLWORM In some regions where tomatoes are largely grown, these caterpillars feed upon the green fruit, often boring into it in a very destructive manner; consequently, they have received the name Tomato Fruit Worm. In the South, however, the insect does not confine its attention to cotton, for it often fecds also upon green corn even in cotton-growing regions.

As a Corn Worm, the life history of this insect may be summarized in these words: The adult yellowish or yellowish-green moths appear in the cornfield early in the summer and deposit their eggs upon the leaves or stalks of the growing plants. Four or five days later these eggs 
hatch into small caterpillars that commonly hunt until they find the end of a young ear of corn, where they feed upon the green tassels and gradually burrow beneath the husks, eating both tassels and young kernels as they proceed. When once beneath the protection of the outer husks, they remain until they become full grown. They are then a little over an inch long. Each makes a round hole through the husk and enters the soil below the plant, where within an oval cell it changes to a pupa. Some time later it again changes to an adult moth.

The life history of the insect when it feeds upon cotton is very similar, except that the young cotton bolls are attacked instead of the ears of corn. An interesting fact in regard to the species is that in the more northern regions this insect does not seem to be able to survive the winter in any stage. Consequently, it is believed that most of the injury there done each season is caused by moths that fly northward from the south.

The Larger Cornstalk-borer, which is also known as the Sugarcane-borer, is one of the most generally destructive insects in the Southern states. Early in spring, about the time the young corn plants are four or five inches high, a rather small moth appears in the fields and lays eggs upon the leaves of the young corn plants. These eggs soon hatch into small caterpillars that burrow into the stalk until they reach the pith. Then they begin feeding upon this pith, usually burrowing upward. They continue to feed and grow for several weeks, often coming out of the original plant and burrowing into a neighboring one. About midsummer, they become full grown in the larval state. Then they change to pupæ inside the tunnels within the cornstalks, to emerge a fortnight later as adult moths.

These moths lay eggs for a second generation of cater- 
pillars, that burrow into the cornstalks in the same way, and usually remain through the winter in their tunnels without transforming to pupx. Early in spring, however, this transformation takes place, and the moths appear in time to lay their eggs upon the young corn plants of a new season.

This Cornstalk-borer is especially destructive in regions where old cornstalks are left in the field through the winter. The destruction of these, with the hibernating caterpillars inside, will very largely reduce the injury the following season. It is another one of the numerous insects which point the moral that "good agriculture is the first and best insecticide."

\section{Codling Moth}

It is more than a century since the Codling Moth or Apple Worm began to prey upon the fruit of American orchards. This pest was introduced from Europe early in our history. Its life history in brief is this : -

The parent insect is a small chocolate-brown moth, scarcely half an inch long, which appears among the trees in spring about the time the young apples are forming. The tiny whitish eggs are deposited upon the fruit,

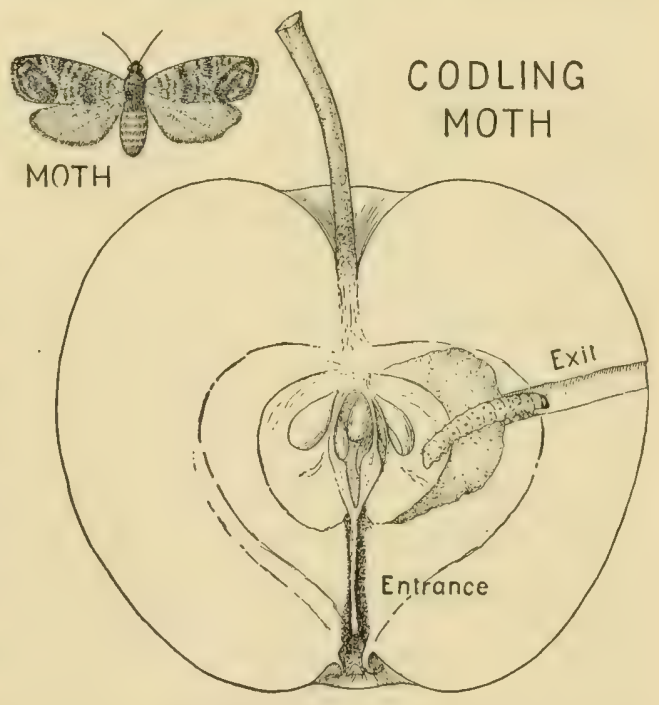
stems, or leaves. These eggs shortly hatch into small larvæ that commonly enter the blossom end of the apple, where 
they are likely to nibble for a few days before they burrow down toward the core. When once within the fruit, they feed and grow for about a month. Then they leave the fruit and find shelter where they spin their cocoons, within which they change to pupx. Each insect remains in this pupal state for about two weeks; then it emerges as an

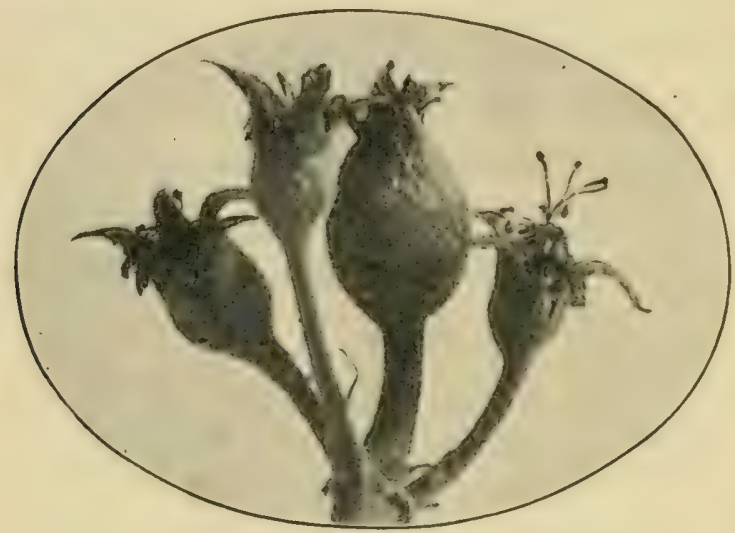

Apples Showing CAlyx Open AND CALYX Closed adult moth, like the one that laid the original eggs.

These moths commonly lay eggs for a second brood of worms, that develop in the apples throughout the late summer or early autumn months. The larva leave the apples when full grown and, in the shelter of rough bark or something similar, spin silken cocoons, within which they remain until about the time the apples blossom the following spring. Then they change to pupx, and change again in about two weeks to adult moths. There are two broods of these moths a year, each distributed over a long period.

The injuries of the Codling Moth larvæ may be prevented to a large degree by spraying with arsenical poisons in spring, soon after the petals of the blossoms have fallen. It is especially desirable that a thorough spraying be given before the calyx end of the young apple is closed. In the picture above, the calyx in each of the outer fruits is open; that of the larger, middle fruit is closed. By means of the spraying machine, the fruit grower is able to place in the 
upper or blossom end of the apple a few particles of poison, so that when the newly hatched worm nibbles at the skin, it is likely to eat one or more of these particles and be killed. Two sprayings are generally desirable; the first less than a week after the petals fall, and the second ten days or two weeks after the first.

\section{Leaf Rollers and Leaf Miners}

Examples of the great group of Leaf Rollers, several families of which are commonly classed together into one superfamily (Tortricina), are easily found wherever there are trees or shrubs in variety. These insects are especially characterized by the ability of the larvæ to fasten together the edges of leaves by means of silken threads. Sometimes it will be a single leaf cleverly rolled into a tube, and at other times it will be a number of leaves upon

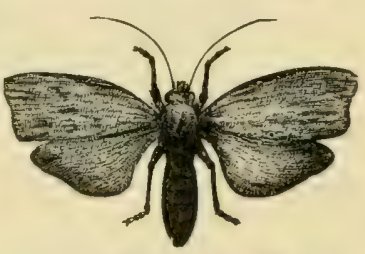

LEAF ROLLER MOTH the same branch, sewed together to make a tent. In either case, the leaves thus united are utilized as a home for the young caterpillars, that feed upon the green substance on the inside, and so escape, to a large extent, the attacks of birds.

When fully grown, the caterpillars change to pupæ, either in the webbed home or in some other shelter, and a little later they change again into small moths. One of the commonest examples of this great group is the socalled Rose Leaf Roller, which is also often found upon the leaves of apple and many other trees Fortunately in the case of most Leaf Rollers, the protecting web does not prevent the access of parasitic flies which destroy the caterpillars in great numbers.

The smallest of the scale-winged insects belong to the 
great group of Leaf Miners (Tineina). For the most part, these insects in their larval stages live between the upper and lower surfaces of leaves as true miners. Some of them, however, have other habits. A comparatively small number make tiny silken cases which serve as houses within which they live. Others burrow in fruits, stems, or seeds. Still others feed upon wool or furs or feathers; the common clothes moths are illustrations of these.

If you will look carefully at the leaves of the nearest apple tree, you will be likely to find illustrations of the true Leaf Miners. Several distinct species live upon the tissues of apple leaves. One of the commonest is the Apple-leaf Trumpet Miner, which is easily recognized by the curious trumpet shape of the yellowish mine that is conspicuous within the green tissues of the leaf. The life history of this species is very simple. A small brown moth lays her egg upon the surface of the leaf. The egg shortly hatches into a tiny larva, that burrows through the skin of the leaf and feeds upon the green cells inside. Here it continues to feed and grow for some weeks, casting its skin occasionally. It remains as a larva within the mines when the leaves fall in autumn. In the spring it changes to a pupa, still within the fallen leaf, and a little later the moth emerges. This insect is sometimes so numerous as seriously to injure the foliage of the trees.

\section{PeACH-Twig Borer}

The insect which in California is known as the Peach Worm and which in many other parts of the country is called the Peach-twig Borer, is one of the most extraordinary of fruit insects. This is due to the remarkable variation of the habits of the larvæ in the three different broods developed during each year. 
The life history of this pest in California has been very carefully worked out by the investigators of the State Experiment Station. In brief it is as follows: Throughout the fall and winter the small caterpillars are hidden within curious cells that they make in the bark of the trees, especially in the forks of the branches. These little burrows are furnished with a silken lining, and are covered with a sort of thatch made by fastening tiny bits of bark together with silk. Within these hibernating cells, the insects are protected from most dangers. Early

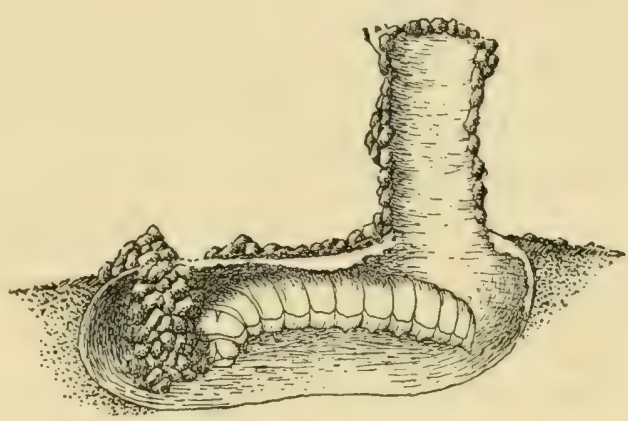

PEACH-TIVIG BURER: WINTER BURROW CUT OPEN in spring, the larvæ become active and get ready to emerge from their winter quarters by tearing away a part of the protective covering. Finally they emerge and attack the young buds, burrowing their way into the pith of the short branches. They thus become twig borers, and often do great damage.

After a few weeks of this existence, they hide within the bits of curled bark upon the trunk and larger branches, where they change to pupæ, generally very slightly sheltered by a few silken hairs. These pupæ shortly change again into adult moths, that lay their eggs on the bark of the young twigs. These eggs soon hatch into tiny larvæe, which also become twig borers during the first weeks of their life, usually upon a tree loaded with fruit. This brood of worms lives as twig borers for only about three weeks.

They then leave the twigs and burrow into the green peaches, entering at the stem end and feeding freely upon 
the green pulp. Here they continue until they become full-grown as larvæ, often doing an enormous amount of damage to the peach crop. Finally they emerge from the fruits and change to pupæe on the outside of the peach, generally in or near the stem cavity. A week later, these pupre change to moths that deposit their eggs upon the peaches, and these eggs hatch into worms that also burrow into the peach fruits, finally maturing and pupating on the outside of the fruits in the same way that the second generation did.

A week later, the third brood of moths appears, generally during the latter part of August, and these deposit their eggs upon the bark of the trees. The larvæ that hatch from this lot of eggs burrow immediately into the bark and hollow out the hibernating cells.

There is thus in the extraordinary history of this Peachtwig Moth a series of three broods of larvæ, one of which is exclusively a borer of bark and twigs, the second of which is both a twig borer and a fruit worm, and the third of which, on fruiting trees, is exclusively a fruit worm. It has been found that the hibernating worms may be destroyed by spraying the trees in spring with a lime, salt, and sulphur wash, and the injuries may be prevented to a considerable extent by burying or covering the piles of wormy peaches.

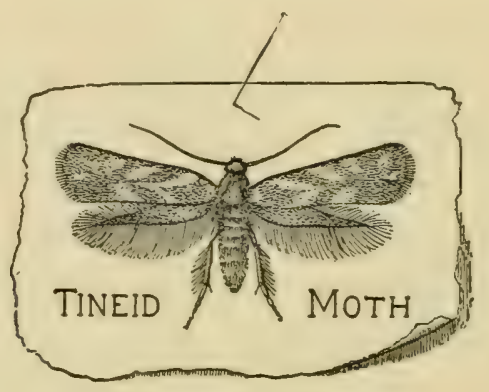




\section{OBSERVATIONS FOR PUPILS}

\section{ButTERfLies}

A

I. Make a list of butterflies that you know by sight. If you have access to the Butterfly Book or Comstock's How to know the Butterflies, you can identify those you see.

2. Keep the caterpillars of some butterflies in a vivarium to see their changes. You can probably find some one of these : the Cabbage Worm, Orange-dog, Monarch Butterfly caterpillar on milkweed, Black Swallow-tail caterpillar on parsley, celery, or parsnip plants or the Mourning Cloak Butterfly caterpillars on willow, poplars, and elm.

3. Read some of the chapters on Butterflies in Dickerson's Moths and Butterflies; also such of the following as you have access to : -

American Insects, pages 446-454. Nature Biographies, pages I-IO, II-2I, 7I-88. Stories of Insect Life, First Series, pages 12-17, 22-27, 37-40.

\section{$B$}

I. Write or tell the story of The Life of a Butterfly. Follow some such outline as this :

The laying of the egg.

The hatching of the larva.

The growth of the larva.

The change to the chrysalis.

The change to the butterfly.

The habits of the butterfly.

If the story is written, illustrate it by some sketches of the life stages.

\section{SPHINX MOTHS}

I. Late in summer or early in autumn one can generally find larvæ of Sphinx Moths by a little searching of these plants : Tomato, grape, woodbine, or Virginia creeper, purslane, and various trees and shrubs.

2. When a Sphinx larva is found, keep it in a vivarium with two inches of earth in the bottom. Feed it regularly and keep the vivarium clean. When it is full grown, it will probably enter the soil to pupate. Then put the vivarium away in a cool cellar till spring.

3. Read these accounts of Sphinx life histories:-

American Insects, pages 43I-439. Moths and Butterfies, pages 224-242. Stories of Insect Life, Second Series, pages 38-45, 56-62. 


\section{BOMBYCINE MOTHS}

I. In winter or early spring hunt for cocoons of the giant silkworms - Cecropia, Promethea, Polyphemus, and other large moths. When found, keep in a cool place until April or May, then bring into the schoolroom to see the moths emerge.

Read the chapters on these moths in Dickerson's Moths and Butterfies.

2. In spring you can easily find nests of the Tent Caterpillar. Bring in a few larvæ and rear in a vivarium.

Read Natiire Biographies, pages 22-34.

3. In autumn you can generally find nests of the Fall Web-iworm and easily rear a few of the larvæ.

\section{OTHER INSECTS}

I. If you do not find Cutworms in your garden. you can probably find them under boards along fences or roadsides. Keep a few in a vivarium, feeding them leaves of clover, and see if you can rear them successfully.

2. If the Bollworm. Corn Worm, or Tomato Fruit Worm occur in your region, see if you can find and rear some of the larvæ.

3. Late in autumn get some nearly full-grown Codling Moth larvæ in apples, place in a vivarium, and see if you can get them to spin cocoons. Keep these to see if you can get the moths from them.

4. Make an estimate of the percentage of apples injured by the Codling Moth in some orchard. Is the injury less in orchards sprayed in spring than in those not sprayed?

5. A little searching of the leaves of trees and shrubs at almost any time in summer will reveal examples of leaf rollers at work. One species is common in the leaves of cultivated strawberries. Another conspicuous one is the Wild Cherry Tent-maker. Rear some of the larva into moths. A few small caterpillars can be easily reared in a covered jelly glass or a glass fruit-jar.

6. Examine the leaves of apple and other trees for leaf miners. They are generally abundant in summer and early autumn. Break off a twig with infested leaves and put it in a bottle of water to keep the larvæ alive until they change to pupæ. Then put the leaf in a jelly glass or other suitable receptacle, covering with cheesecloth held in place by a rubber band. 


\section{THE BUTTERFLIES AND MOTHS}

7. Examine peach trees and peach fruits for the Peach-twig Moths. See if you can rear the moths.

Read such of these references as your teacher may request:-

The Brown-tail Moth and How to Control It, Farmers' Bulletin 264. The Gypsy Moth and How to Control it, Farmers' Bulletin 275. The Cotton Bollworm, Farmers' Bulletin 29o. Insects Affecting the Cotton Plant, Farmers' Bulletin 47. The Imported Cabbage Worm, U. S. Bureau of Entomology, Circular 6o. The Peach-tree Borer, U. S. Bureau of Entomology, Circular 54.

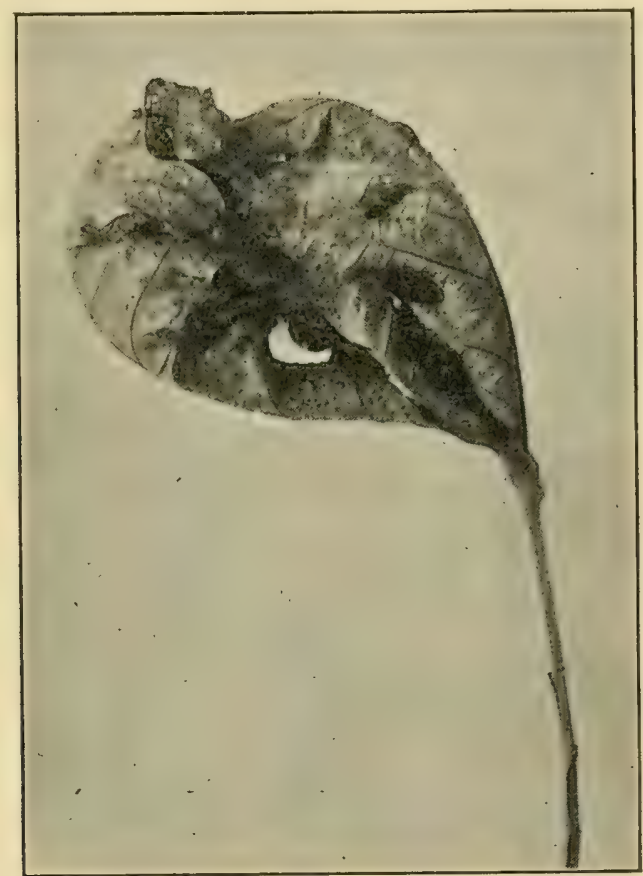

WINTER NEST OF BROWN-TAIL MOTH 


\section{CHAPTER IX}

\section{The Two-winged Flies}

So far as numbers of individuals are concerned, the Two-winged Flies of the order Diptera are among the most

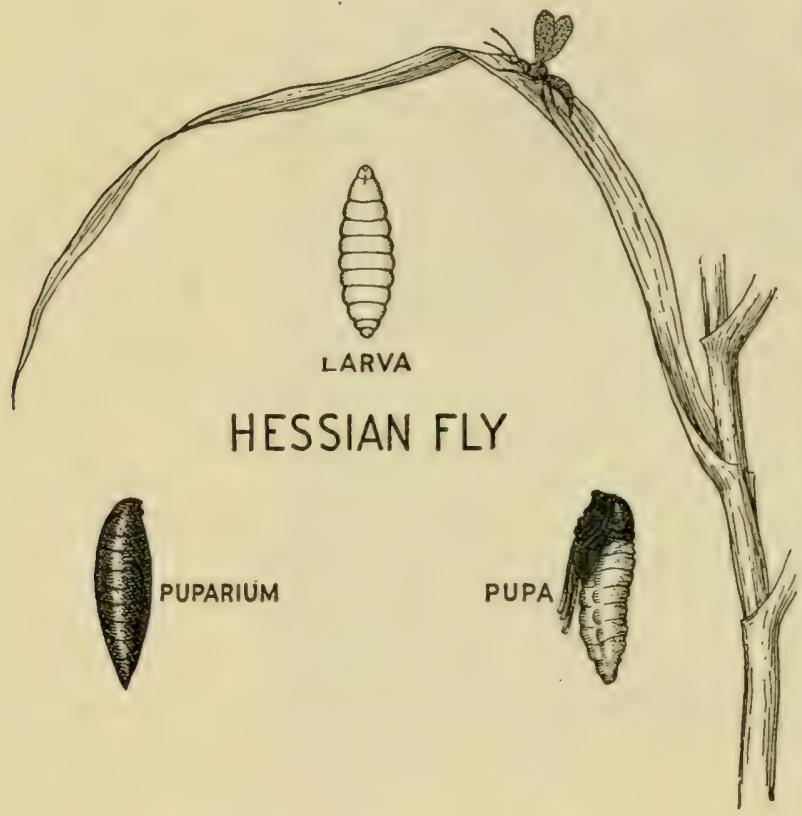

abundant of all insects. These are distinguished by the fact that there is but one pair of wings, although in most species there is a pair of curious little projections called halteres or "balancers" which represent the second pair of wings. The flies have complete transformations, and in the larval state commonly exist as footless maggots. The mouth parts are formed for sucking, although there are often special modifications for biting, in connection with the sucking apparatus.

Fortunately, there are comparatively few species of Diptera that are destructive to cultivated crops. Among these few, however, are some of the most troublesome of all injurious insects, such as the Hessian Fly, the Apple Maggot, 
the Pear Midge, the Clover-seed Midge and certain other pests.

\section{Gall Gnats}

The Hessian Fly belongs to the family of Gall Gnats (Cecidomyiidæ). These are mosquito-like flies which live in the larval state upon the growing tissues of plants, commonly causing an abnormal swelling, which is called a gall. In the case of the Hessian Fly, the adult insect is a small creature with smoky brown wings, which appears i:l the wheat fields in autumn soon after the young plants are up. It deposits eggs upon the leaves, generally a little above the joints. These eggs shortly hatch into very small maggots that work their way down to the joints and into the space between the sheath and the main stalk. Here they remain and gradually absorb the sap of the plant. They grow rather slowly, and their presence causes a slight swelling of the surrounding tissues and prevents

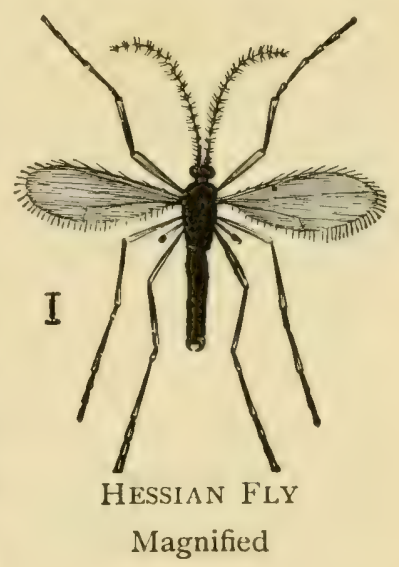
the normal growth of the young wheat plant. After some weeks, they become full grown in this larval stage, and now change to what is called the flaxseed condition. To bring about this change the outer skin of the larva separates from the skin beneath and gradually hardens into a brown protective covering. This covering, which looks like a flaxseed, is commonly said to be the puparium. It corresponds in a way to the cocoon of a moth in that it serves as a protection to the insect inside, although its method of formation is entirely distinct from that by which a cocoon is formed.

The larvæ remain within these flaxseeds throughout 
the winter. In the spring, still inside, they change to pupæ, and a little later change again to adult Hessian Flies. These adults lay eggs for another generation of larvæ that attack the wheat in the spring and cause much of it to be so dwarfed and weakened that the crop is seriously injured. As a rule, this brood of flies seems not to become mature until the latter part of the season.

In the case of an insect so minute and so protected during its earlier stages as the Hessian Fly, many insecticidal methods of controlling it are useless. Consequently, farmers must resort to agricultural methods if they would prevent damage by it. One of the most successful of these methods is that of planting narrow strips of wheat early in the fall, to attract the flies to lay their eggs, in order that the main crop of wheat planted later may escape infestation. The early trap crop may then be plowed under, so that the eggs and larvæ present will be destroyed.

Another insect belonging to this same family and also attacking the wheat is called the Wheat Midge. The larva in this case are found in the heads of grain rather than in the stalks, and the damage they do is in the destruction or divarfing of the kernels of wheat. In recent years this insect seems to have done comparatively little damage.

Closely related, both in structure and habits, to the Wheat Midge is a tiny fly called the Clover-seed Midge. The flies lay their eggs in the blossom heads of clover, and the eggs hatch into larvæ that develop at the expense of the young seeds, often causing a serious lessening of the crop where clover is grown for seed. The injury to hay crops, however, is very slight.

The Pear Midge is the most destructive insect of this family that attacks fruit. The eggs are laid in the flower 
buds and hatch into larva that attack the seed cavities of the young pears, sometimes doing serious damage. When fully developed in the larval state, they drop to the ground where they change to pupæ, and emerge soon after as adult flies. Plowing during the latter part of June and fertilizing with a heavy dressing of some potash fertilizer is helpful in destroying the larvæ and pupæ.

\section{CRAne Flies}

The Crane Flies (Tipulidæ) are among the largest of the Two-winged Flies. These insects look like gigantic mosquitoes and may be seen throughout the summer in pastures and meadows, as wellasabout houses. In their larval stages some of the commoner Crane Flies feed upon
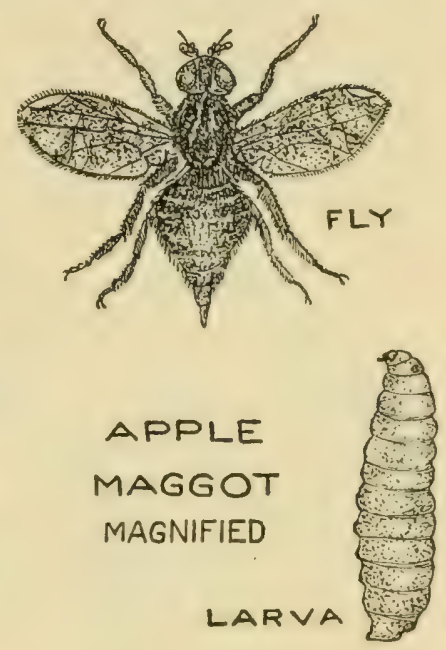
decaying vegetation and occasionally upon grass roots, although they are very seldom destructive in America. These flies show very well the peculiar balancers that represent the second pair of wings.

\section{Fruit Maggots}

Comparatively few Two-winged Flies are injurious to fruit crops. One of the most destructive of these is the Apple Maggot or Railroad Worm, a pest that is often very troublesome in orchards. The adult fly deposits eggs beneath the skins of young apples during the summer. Each of these eggs soon hatches into a small footless maggot that tunnels through the fruit in all directions. It continues the work for five or six weeks, by which time the apple is pretty well "railroaded" and ruined for cooking or eating 
purposes. The injured fruit is likely to fall to the ground. Then the maggot leaves it and finds shelter in the soil or in the rubbish at its surface. Here it changes to a pupa,

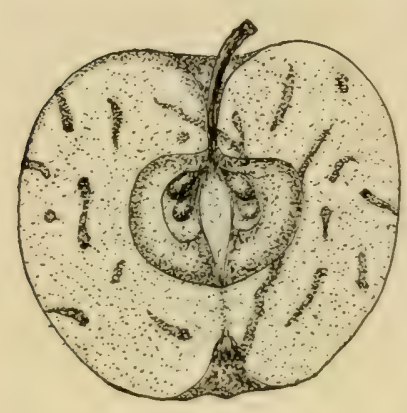

CHANNELS OF

APPLE MAGGOT and remains until the following season when it emerges as an adult fly. Thus there is but one brood each year.

Unfortunately the injuries of this insect cannot be prevented by spraying. The eggs are deposited beneath the skin of the fruit out of the reach of insecticides. The best method of checking its increase is that of picking up or feeding to stock, the fallen apples, so that the worms will be destroyed before they go into the ground. This is another insect that indicates the necessity of coöperation in agricultural methods.

A closely related insect, which has done a great deal of damage in Mexico, is the Orange Maggot or Orange Fruit Fly. This attacks oranges in very much the same way that the Apple Maggot attacks apples. When introduced into an orange-growing locality, it is likely to become a serious pest. The fact that there was constant danger of its introduction into the orange-growing regions of California has caused much discussion among horticulturists. It is one of those pests for which fruit growers should be constantly on the watch, although, of course, there is no danger of damage from it in regions where the citrous fruits are not grown.

\section{Root MAggots}

There are a number of destructive species of flies belonging to the Root-maggot group (Anthomyiinæ). In 
the adult state, these flies bear a general resemblance to the familiar house fly, although commonly they are somewhat smaller and are easily distinguished by experts. The Cabbage Maggot, which is also known as the Radish Maggot, and the Turnip Maggot, is a good example of these insects. The adult flies appear in the cabbage fields when the plants are set out, and deposit their small white eggs about the base of the stalks. A few days later these eggs hatch into tiny, whitish, footless maggots that attack with their rasping mouth parts the outer tissues of the roots. They continue to feed and grow for three or four weeks, commonly causing the death of the plant on account of the destruction of the sec-

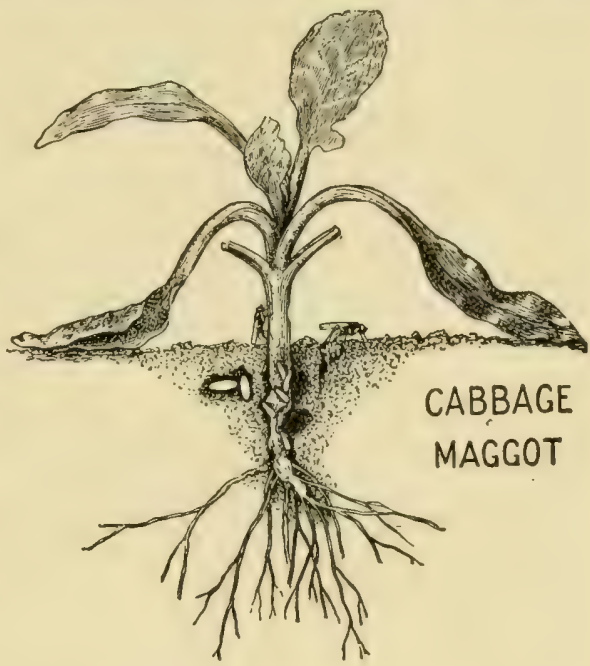
ondary roots or of the girdling of the primary root. By the end of this period they become full-grown as larvæ and change to pupæ.

This process of changing to the pupa state in a large proportion of the two-winged flies differs from that of most other insects. The insects are unable to spin cocoons, but they get the protection of an outward covering in this way: The skin, which in most insects is cast off when the larva changes to a pupa, in these maggots gradually hardens and becomes brownish in color. It does not split open anywhere, so that it forms a covering to the insect, inside which the latter becomes a pupa after this outer skin, which is now called the puparium, has hardened. It remains within this puparium about a fortnight when it again changes into 
an adult fly that breaks through the outer shell and emerges to the sunlight. The formation of the puparium takes place in the soil an inch or less below the surface.

As the common names already mentioned indicate, this little pest is by no means confined to cabbage; it attacks radishes and turnips, as well as a variety of wild plants belonging to the mustard family. There are several broods each year. The insects commonly pass the winter as adult flies, although a certain proportion of them hibernate also in the puparia.

The Cabbage Maggot has been one of the most troublesome insects that the gardener has to fight. It is often very destructive in seed beds where the young cabbages for late planting are being grown. Recent experiments have shown that the best way of preventing this injury is to surround the seed beds with a broad frame twelve inches high, tacking cheesecloth over the frame. If the frame is so tight that no flies can enter, the seedlings will grow rapidly and be free from injury not only by these maggots, but also by the flea beetles which are often very destructive to such seedlings. When the plants are large enough to set out, the cloth should be removed and full exposure to the sun be given for at least a week. This is to harden the seedlings so that they may be transplanted successfully.

The Onion Maggot is another vexatious insect belonging to this family, which is very similar to the Cabbage Maggot in its appearance, habits, and life history. It attacks onions, especially the young plants, and in many regions is the most destructive enemy of this crop.

Another group of insects belonging to this same family attacks the leaves of cultivated crops instead of the roots. The adult flies deposit their whitish eggs upon the surface of the leaves of beets, spinach, and other succulent plants. 
These eggs very soon hatch into small maggots that burrow through the outer skin of the leaf and begin to develop as miners of the interior tissue. They thus become true leaf miners, and their presence is soon shown by the difference in the color of the surface of the leaf. By holding such a leaf up to the light, the maggot inside can generally be seen. These larvæ continue to develop within the leaf for a few weeks before they become full grown, and by this time a single larva will have injured a large portion of a leaf. When full grown they burrow through the outer skin and drop to the ground, where they change to pupæ slightly below the surface. A little later they again change to adult flies. There appear to be several broods each year.

As is the case with the root maggots, these leaf-mining species are by no means confined to cultivated crops. They may very commonly be found at work upon wild plants, such as the white pigweed or some of the commoner docks.

\section{OBSERVATIONS FOR PUPILS \\ HESSIAN FLY}

I. If you live in a wheat-growing region, learn what you can about local damage by the Hessian Fly. If not now injurious, ask your farmer friends if it has been in the past.

2. Examine wheat fields to see if you find injured plants. If so, look for the larvæ or "flaxseeds" of this insect.

3. If found, place the flaxseeds in a glass dish to see if you can rear the flies.

4. Read the account of the Hessian Fly in Circular 70, Bureau of Entomology, U. S. Department of Agriculture.

\section{Apple Maggot}

I. If you live in an apple region, determine whether this insect is present. Examine windfalls of early varieties to see if the characteristic burrows in the pulp are present. 
2. If the pest is at work, gather some injured apples, and place in a box with an inch or two of soil in the bottom. The larvæ will probably enter the soil, and you will be able to rear the flies.

\section{Root Maggots}

I. What crops in your region are injured by root maggots ?

2. Get some of the maggots from roots of radish, turnip, cabbage, or onion. Keep in moist earth and see the change to puparia and later to flies.

3. Try to find eggs, larvæe, and puparia about the roots of injured plants.

\section{LEAF-MINING MAGgotS}

I. Examine the leaves of beets, spinach, dock, and pigweed to find discolored areas. If made by the leaf miners, the larvæ may readily be seen by holding the leaf up to the light or by opening the mine.

2. Place some of the leaves that have larva of good size in a bottle of water. Set in a vivarium with earth in the bottom. The larvae will probably pupate in the earth and later change to flies.

\section{The Story}

Tell or write the life story of one of these injurious flies that you know most about. Illustrate by drawings on blackboard or paper. Perhaps this outline will help you :-

Size, color, and appearance of the fly.

When and where the flies are found.

When and where the eggs are laid.

Size and color of the eggs.

How soon the eggs hatch.

What the larvæ feed on.

How long the larvæ live.

Where the larvæ change to pupæ.

How long before the pupæ change to flies. 


\section{CHAPTER X}

\section{The Beetles: Order Coleoptera}

THE great order of sheath-winged insects to which the beetles belong is one of the largest and most important groups of insects.

Most of its members have hardened wing covers over the true wings, and the whole outer surface of the body is hardened in

a characteristic manner. The larvæ are grubs

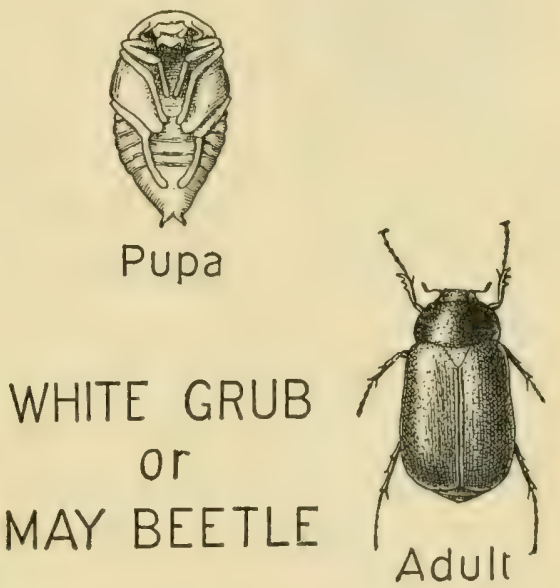

Egg

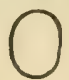
that vary greatly in form and habits, and the pupa is a quiet stage in LARVa

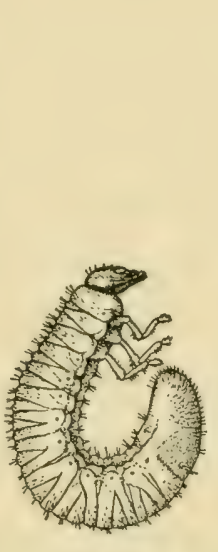
WHITE GRUB MAY BEetLe which the insect does not eat or move about.

The feeding habits of the adult beetles are exceedingly varied; many feed upon plant tissues; many others upon animals, alive or dead. Among the plant-feeding groups are some of the most troublesome, injurious insects, while among the animal-feeding forms are some very beneficial insects. 


\section{LAMELLiCORN BEETLES}

Only a few of the great number of beetle families can be considered in these pages. One of the most important of these is the great group of Lamellicorn Beetles (Scarabrids). These have curious enlargements on the ends of

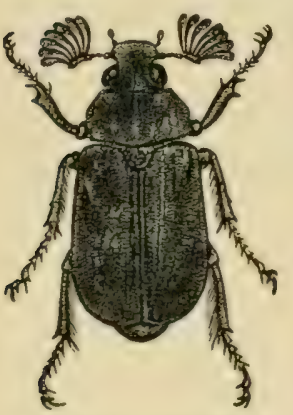

LANELLICORN BEETLE the feelers or antennæ, each swollen part consisting of a number of thin plates resting upon one another. The May Beetle is a typical example of this group.

In both its adult and its larval condition, the May Beetle or June Bug is only too familiar to most people. From the advent of the first warm days in spring until summer is well along, the brown beetles are likely to be seen flying about trees or lights or crawling along the surface of the ground. These beetles feed freely upon the leaves of a great variety of fruit and shade trees, sometimes doing much injury in this way. They deposit their eggs about the bases of grass stems, ind the eggs soon hatch into small larva that feed upon the roots of grasses and gradually develop into the well-known white grubs, which are almost always to be found in abundance when grass lands are plowed. It is believed that these white grubs require at least

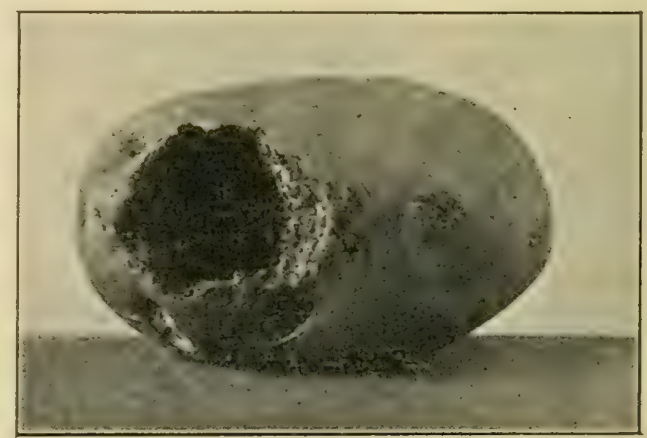

POTATO INJURED BY White GRUB Reduced three years to complete their development, becoming large toward the end of this period and able to destroy the roots 
of many plants. They finally change to pupæ in earthen cells and generally change again to adult beetles in late summer or autumn. The beetles remain in the soil until the following spring.

The white grubs have many enemies among birds and wild animals, such as foxes and skunks. These natural enemies are the most potent means of keeping them in check in regions where the grubs become destructive. The killing of the adult beetles by attracting to lights or collecting in other ways will often become necessary. This is a case, however, where concerted action by all the farmers of the community is exceedingly desirable.

Another vexatious member of this great family of beetles is the so-called Rose Chafer or Rose Bug. This is one of the most destructive enemies of fruits. The brown beetles appear in vast swarms early in summer, when the wild roses are in blossom. They feed upon the leaves and flowers of a great variety of fruit and ornamental plants, such as apples, pears, plums, peaches, roses, raspberries, straw-

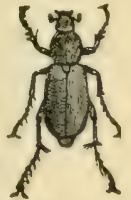

RoSE

CHAFER berries, blackberries, and grapes. They often do serious damage to the grape crop by eating the blossoms. The beetles remain active two or three weeks. During the latter part of this period, the eggs for a new brood are laid in the ground. The insect chooses for this purpose open fields and meadows having a sandy soil. About a fortnight later, the eggs hatch into small grubs that feed upon roots of grasses. These grubs become full grown, or nearly so, during the summer and early autumn. On the approach of winter, they burrow deeper, and the following spring again work their way upward near the surface. Here in earthen cells they change to pupæ, and emerge a month later as fully developed beetles. 
This is a difficult pest to contend against. The most effective method as yet employed is the laborious one of picking the beetles by hand and destroying them.

\section{Click Beetles}

Every farmer's boy is familiar with the slender, yellow Wireworms so commonly found when grass lands are plowed. These insects feed upon the roots of grasses and grains. They often become seriously destructive to crops

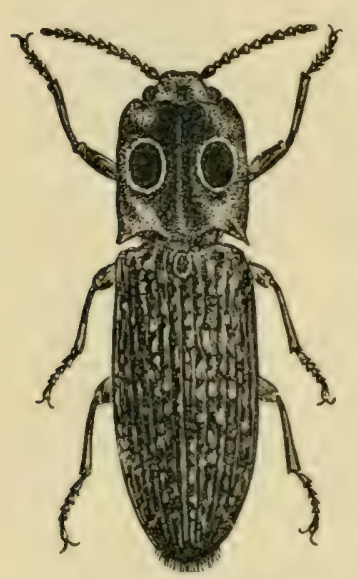

EYED ELATER

planted upon ground that has been in sod for several years. When fully developed in their larval stage, these Wireworms change to pupæe within oval cells in the soil and a few weeks later change again into adult Click Beetles or Elaters. They usually remain, however, within the cells until the following spring, the tissues gradually hardening until they become very firm and hard even for a beetle. Then the adults come forth and fly freely about, often visiting various flowers from which they lap up the nectar. These Elaters are often called Snapping Beetles from the fact that when placed upon their backs, they snap upward, apparently in an effort to regain the crawling position. It is supposed that the eggs are laid about the roots of grasses.

The Wireworms are very difficult to destroy by any form of insecticides. The most desirable method of checking their increase seems to be that of fall plowing, which breaks up the pupal cells and exposes the beetles to destruction by weather conditions through the winter. 


\section{Leaf Beetles}

One of the most generally destructive families of beetles is that of the Leaf Beetles (Chrysomelidæ). As a rule, these are elongated or roundish beetles, having jaws especially adapted for feeding upon leaves. Their larvæ, for the most part, are short, thick grubs, with well-developed thoracic legs. They feed in both the larval and adult states upon a great variety of wild and cultivated plants, and often become seriously destructive to the latter.

No member of this great family is so generally

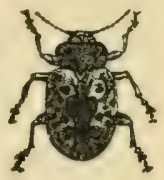

$\mathrm{LE} A \mathrm{~F}$

BEETLE and unfavorably known as the Colorado Potato Beetle. Originally a native of the Rocky Mountain region, where it fed upon a wild species of Solanum, - the genus to which the common potato belongs, - it started eastward as soon as the settlers' garden patches connected its home with the Atlantic states by means of a practically continuous potato field. Then it boarded transatlantic steamships and stole

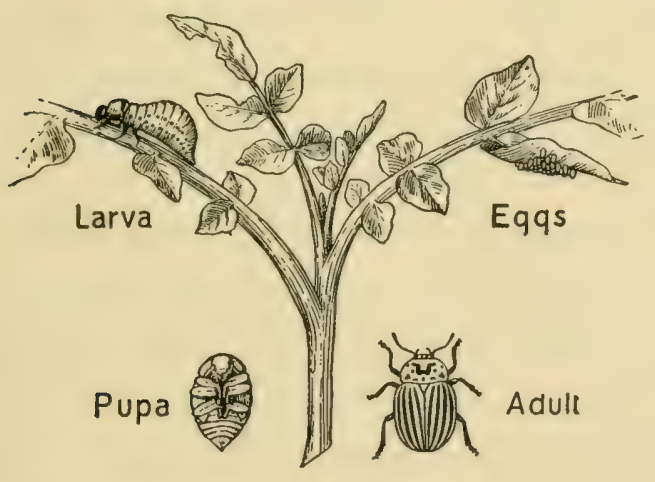

COLORADO POTATO-BEETLE

a passage to Europe, where it gained a decided foothold before receiving the attention it deserved.

The various stages of the Colorado Potato Beetle are shown in the accompanying pictures. Thebrown-striped beetles deposit the orange-colored eggs in masses upon the leaves. These eggs shortly hatch into the curious brown grublike larva, which feed upon the tissues of the leaves and cast their skins 
occasionally as they increase in size. In three or four weeks, they become full-grown as larvæ. Then they make their way into the soil and change to pupre. Ten days later they change again to adult beetles. The number of broods varies with the latitude, there being from two to four each year. The eggs are eaten by lady-bird beetles, and the adults are devoured by certain birds, notably the grosbeaks and the bobwhite. Both larva and adults are readily killed by spraying or dusting the potato vines with arsenical poisons.

Another leaf beetle that is very often destructive is the Asparagus Beetle. This is one of those numerous pests that have been introduced into America from Europe. It is not yet generally distributed, but is constantly being introduced into new localities where asparagus is grown. The adult beetle is rather slender, less than half an inch long, and is easily recognized by the brilliant combination of black marked with red or yellow. When such a beetle is found feeding upon asparagus, it is pretty certain to be this Asparagus Beetle. If there are twelve spots, however, it is probably the less common Twelve-spotted Asparagus Beetle, which has also been lately introduced from Europe.

The eggs of the common Asparagus Beetle are deposited upon the leares and stems of the plants, and soon hatch into small grublike larva that feed freely upon the leaves, often doing great damage to young plantations. These larra pupate in the ground and soon emerge again as adult beetles.

Various methods of checking Asparagus Beetles have been found successful on young plantations. Dusting the vines when they are wet with dew with fresh, dry air-slaked lime has been found to kill the larvæ. On older planta- 
tions, which are being cut over, the leaving of a few stalks as trap plants to attract the adult beetles when they lay their eggs has been found effective. These trap plants, of course, are to be destroyed often enough to prevent the eggs from hatching.

A much more familiar and widely distributed leaf beetle is the common Striped Cucumber Beetle, which is found practically everywhere that cucumbers, melons, squashes, or related plants are grown. These insects pass the winter as adults under such shelter as they may find, and in spring feed ravenously upon the young cucumber or other plants. They also deposit their eggs about the roots of these plants, and the eggs shortly hatch into slender larvæ that feed upon the roots. In this way, the beetles not only threaten the crop in their adult state, but they often do a more serious, though less recognized, damage in their larval state. These are among the most difficult of all pests to keep in check. A few hills may be covered with netting or cloth. The liberal use of refuse tobacco powder is generally also an efficient protection. The complete destruction of all squash, cucumber, melon, and pumpkin vines as soon as the crop is gathered is a very desirable preventive measure. If these are left, the adult beetles find abundant food up to the time they go into their hibernating quarters, and consequently are in better condition to survive the winter.

A closely related insect, which at times has been exceedingly destructive, is the Northern Corn Rootworm. This is a small beetle, about the size of the Cucumber Beetle, but of a uniform pale green color. In the larval state it feeds upon the roots of corn and so weakens the plants that the development of the crop is greatly checked. The larva change to the pupa state and 
emerge as beetles during the later part of summer or early in autumn.

These beetles then deposit eggs in the same fields in which they were developed and the eggs remain unhatched until the following spring. If corn is then planted, the larvæ feed again upon the roots and repeat the injury of the season before, but if the field is planted to some other crop upon which the larva are unable to develop, the insects will die and the damage will be prevented. Consequently this Corn Rootworm has been a blessing in disguise, for it has compelled those farmers who were depleting the fertility of their land by a constant succession of corn crops, to adopt a system of rotation. The discovery of the life history of the Northern Corn Rootworm and the pointing out of the fact that its injuries may be prevented by the rotation of crops is one of the most notable examples of the benefits to be derived from scientific entomology. The credit for it is due to Dr. S. A. Forbes, the state entomologist of Illinois.

The insect known in many of the Northern states as the Twelve-spotted Cucumber Beetle, is also known in the South as the Southern Corn Rootworm. Throughout its range, it feeds as an adult upon succulent leaves, and probably develops as a larva upon a considerable variety of plant roots. In Kentucky and some other Southern states it causes much damage to corn crops. Its Southern life history is briefly this: The adult beetles hibernate at the surface of the soil or just below, in fields of clover, alfalfa, and other crops. They come forth early in spring, and as soon as the young corn plants are well started, they deposit their eggs about the roots. The eggs soon hatch into larva that become full grown early in summer, changing to pupæe and soon again into adults which appear 
about midsummer. In a short time, these lay eggs for a second brood of larvæ that develop into adult beetles in autumn. These beetles hibernate until the following spring. There are thus two broods of larvæ each season.

The fact that this Southern Corn Rootworm hibernates in the adult condition and that the beetles can fly freely from place to place, shows at once that this pest cannot be checked by the simple method of rotation that serves the purpose in the case of the Northern Corn Rootworm. Rotation of crops will be helpful, especially if care is taken not to plant to corn those fields to which the adult beetles were attracted the previous autumn by an abundant supply of succulent food.

\section{Flea Beetles}

There are several species of Flea Beetles which also belong to this leaf-beetle family. Some of the larger Flea Beetles have a life history similar to that of the Asparagus Beetle and the Colorado Potato Beetle, both larvæ and adults feeding upon the foliage of the food plants. The Grape Flea Beetle is an excellent example of these insects. It often becomes a destructive pest in vineyard regions.

The smaller Flea Beetles, however, are more universally distributed and affect a great variety of cultivated crops. These are tiny beetles which are able to jump great distances when disturbed, and which are only too commonly

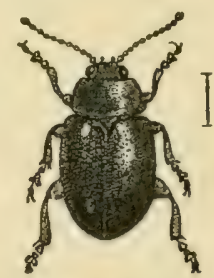

FLEA BEETLE Magnified found upon potato, tomato, cabbage, and other garden plants. They not only do decided damage by eating out the surface of the foliage, but they afford an easy ingress for the germinating spores of ruany kinds of fungous diseases. In their larval state, some, at least, of these smaller 
Flea Beetles live as miners in the leaves and stems of various plants. Spraying with Bordeaux mixture is one of the best methods of preventing their injuries.

\section{LONG-HORN BEETLES}

The so-called Long-horn Beetles (Cerambycidæ) form one of the most important groups of the order. The adults

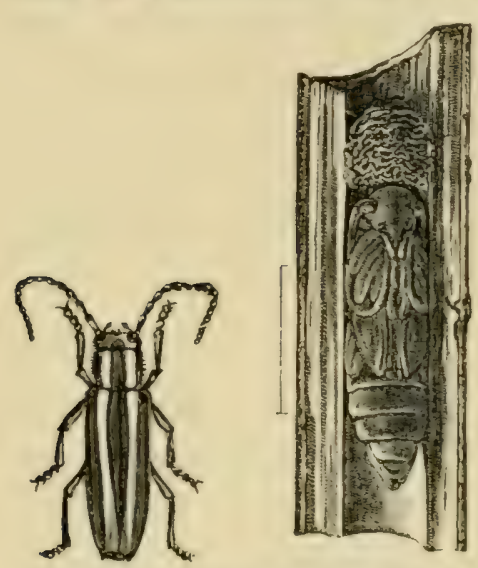

ROUND-HEADEI APLE-TREE BORERS

Beetle and Pupa have cylindrical bodies, frequently of large size, with feelers or antennae generally as long as the bodies or longer. These beetles deposit their eggs upon the bark or wood of a great variety of trees and shrubs, and the eggs hatch into footless grubs that burrow into the bark or wood of the host plant. Some of the most destructive fruit-tree pests belong to this family, a notable example being the Round-headed Apple-tree Borer, which is often very injurious in apple orchards.

The Locust Borer is one of the most abundant as well as most beautiful of the beetles belonging to this family. It is attractively colored, being brown or black, marked and striped with lines of light yellow. This beetle is very abundant in late summer and early autumn upon the flowers of goldenrod, which it visits in search of pollen. The life history briefly summarized is this: The beetles found in August or September deposit their eggs one at a time in the crevices of the bark of the common or

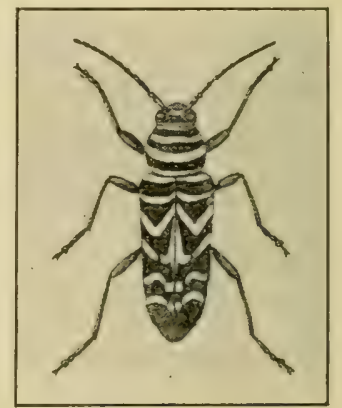

LOCUST BORER BeETLE 
black locust trees. In about ten days these eggs hatch into tiny larvæ that excavate slight cells in the bark; they remain in these cells throughout the winter. Soon after the sap begins to flow the following spring, the larvæ become active and begin to burrow through the bark into the wood. The burrows that they make are commonly not very long and are enlarged as the insects increase in size. The larvæ become full grown in a few months, and change to pupæ within their burrows about midsummer. A little later they change again to adult beetles that come forth to feed upon goldenrod flowers and deposit eggs for another generation of borers.

The characteristic larvæ of various wood-boring beetles are very often to be seen when firewood is split up, dropping out of the cylindrical chambers they have burrowed in the wood. They may also frequently be found beneath the bark of fallen trees or in the partially decayed wood of dead stumps. Some species are much more destructive than others, but in general their life histories are quite similar. The Pine Sawyer is a large species that breeds in dead pine trees and often causes losses of millions of dollars in a single year. The Oak Twig Pruner is another widespread pest ; it may commonly be found in fallen twigs under oak trees.

\section{Curculios and Other Snout Beetles}

Most farmers' boys know how difficult it is to grow plums. From the time the fruit is half grown until it is ripe it continues to fall to the ground, and when examined is found to be wormy and unfit to eat. This worminess is generally due to the insect known as the Plum Curculio, a small, hard-shelled, brownish beetle, which appears among the plum trees in spring. It gnaws holes in the leaves, 
the flowers, and the green plums to satisfy its hunger. 'The females also cut crescent-shaped holes in the skin of the young fruits and deposit an egg beneath each of the cres-

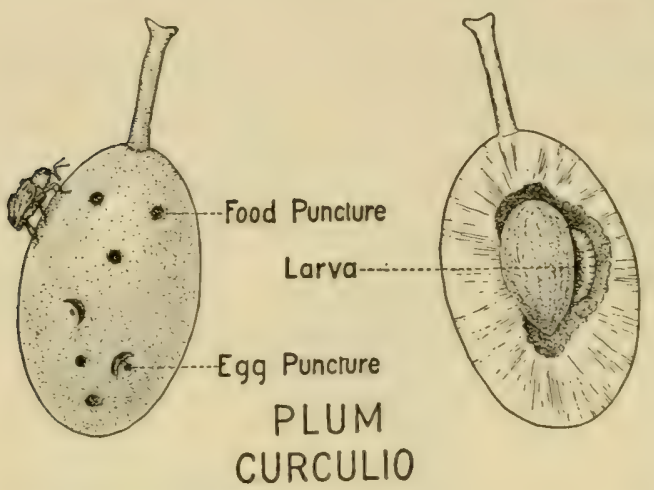

cent marks. In from three to seven days these eggs hatch into little grubs that feed upon the pulp of the fruit, gradually working toward the pit. They become fullgrown in two or three weeks. The infested plums by this time are so injured that they generally fall to the ground. Then the larvæ leave the fruit, and burrow into the soil about an inch, where they change to pupæ. Three or four weeks later, they change again and come forth as perfect beetles. There is but one brood of the worms each season. The adult beetles hibernate under such shelter as they can find at the surface of the soil.

The Plum Curculio is by no means an unmixed evil. In many localities it performs an essential service by thinning the plums, thus saving the fruit grower much expense. Besides plums, it attacks peaches, cherries, apricots, nectarines, apples, and pears. In the case of the last two a large proportion of the larvæ appear to be unable to develop in the

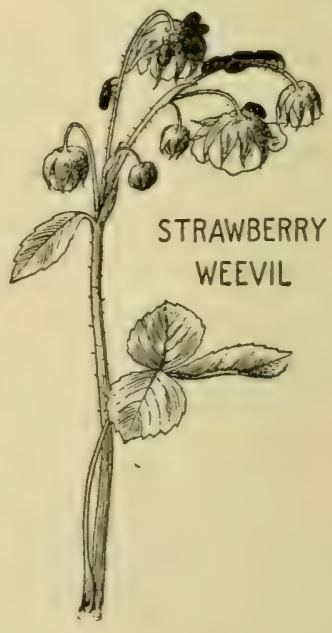
green fruit, but the injuries by the adult beetles often cause the fruits to be dwarfed and gnarly.

There are several natural enemies of the Plum Curculio. 
One of the most efficient of these is the tiny fly that deposits its eggs in the eggs of the Curculio. The fly eggs hatch into maggots that destroy the Curculio eggs and mature in a few days into other flies like the parent parasites. Consequently several generations of these egg parasites may follow one another through the season. There are also other parasites that attack PEACH the Curculio larvæ. The fluctuations in the abundance of the Curculios from season to season is probably due chiefly to these parasitic enemies.

It has been found that even in large orchards the injuries of the Plum Curculio may be prevented to a great extent by spraying the trees with arsenical poisons, beginning just after the blossoms have fallen. The adult beetles feeding upon the leaves and young fruit are thus

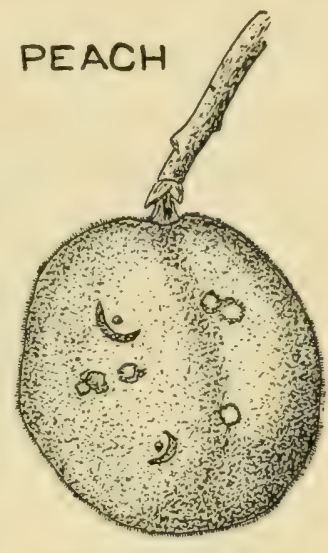

INJURED BY

CURCULIO poisoned. For a few trees this method is not always so successful, and it is necessary to adopt the jarring device. When a branch upon which the adult beetles are resting is shaken, the insects fall to the ground, remaining quiet for some time afterward. By holding sheets stretched upon wooden frames under the trees and then shaking the latter, the beetles may be collected in numbers. It is also often advisable to supplement the spraying, even in large orchards, by the jarring process. The destruction of the plums as fast as they fall and the cultivation of the soil beneath the trees during the summer are also helpful measures.

A group of Snout Beetles that at times has proved very destructive in the great corn-growing regions of the Central West, is that of the Billbugs. These are compara- 
tively large insects, having hard bodies with long snouts, on the ends of which are well-developed jaws by means of which they can burrow through young cornstalks very quickly. The adult beetles feed upon the tissues of these stalks, greatly weakening the plant when they burrow through it. In the case of a typical species, the insect hibernates in the adult state, and attacks the young corn soon after it comes up. The eggs are laid in early summer, commorly about the bulbs of timothy and perhaps other plants, and the larvæ burrow into these bulbs and there develop. They grow rapidly and become mature beetles late in summer or early in autumn.

Some of the best-known species of Billbugs develop as larva in sedges or rushes of various kinds. Practically all of them appear to breed chiefly on low lands where sedges are likely to abound. The cornfields often injured are those upon or near such lands. Fall plowing is an efficient preventive of injury by these pests.

\section{Cotton Boll Weevil}

The Cotton Boll Weevil has attracted more attention during recent years than almost any other destructive

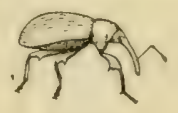

ADULT

\section{MEXICAN}

COTTON BOLL

WEEVIL

insect. Migrating into Texas from Mexico about the year I890, this pest has gradually spread toward the north and east and threatens to become destructive almost everywhere that cotton is grown. Within about a dozen years of its introduction, when it was still 
largely confined within the borders of Texas, the loss to the cotton crop in one year due to this insect was estimated at \$I 5,000,000 by Dr. L. O. Howard, entomologist of the United States Department of Agriculture. The possible annual loss to the cotton planters of the South in case the pest should become generally distributed, has been estimated at $\$ 250,000,000$. Consequently it is not strange that this insect has received a great deal of attention from the national and state governments, and that strenuous efforts are being made to destroy it where it now exists, and to prevent its introduction into new localities.

Briefly stated, the life

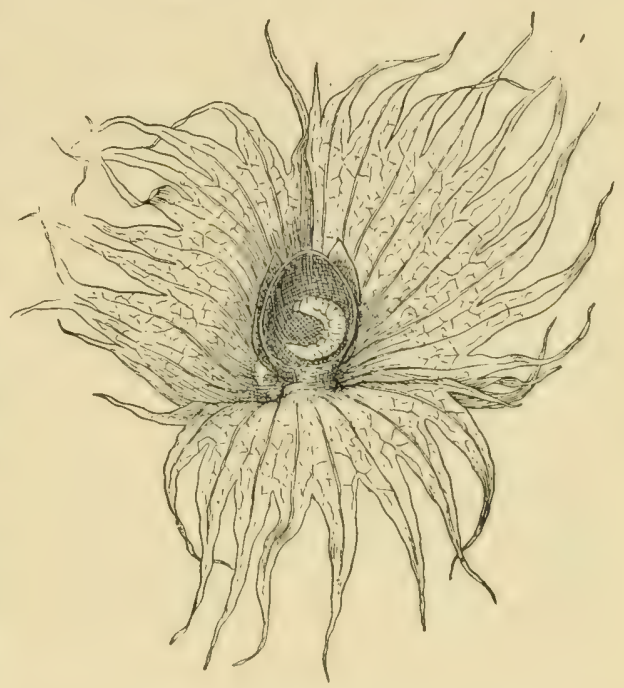

INFESTED COTTON SQUARE history of the Boll Weevil is this: The adult snout beetles pass the winter in a great variety of shelters, in or near the cotton fields. In spring they come forth from their hibernating quarters and attack the young plants, feeding upon the buds, in which they make small round holes. In some of these holes are deposited eggs that soon hatch into whitish, footless grubs that feed upon the interior of the buds, destroying the blossoms and thus greatly injuring the prospects of the crop. These larvæe grow rapidly and in a few weeks become mature, so far as this stage is concerned. They then change to pupæ still within the shelter of the bud, and a little later change to adult beetles. They gnaw their way out and soon deposit eggs for a second 
brood of larvæ. There are several broods during the season, the larvæ being able in the hot weather of midsummer to become full grown, so far as the larval stage alone is concerned, in one week. The later broods develop within the cotton bolls and thus cause a vast amount of damage.

The Boll Weevils continue to multiply through the fall upon any plants that are still present in the fields, and those which hibernate most successfully are the ones that develop latest in the season. Consequently, as a result of many careful observations and experiments, it is pretty certainly established that the most effective practical remedy for the insect is to pull up and burn all the cotton plants present in the fields in autumn. This may usually be done by cutting off the roots with a plow and then at once gathering the plants by hand and piling them in windrows where they will rapidly dry out, and in about two weeks may be burned. The addition of a little crude oil is sometimes desirable to insure the complete destruction of all the stalks. In an interesting experiment conducted by the Department of Agriculture, an isolated cotton-growing region of about four hundred acres was thus treated in autumn, with the result that the beetles were nearly all destroyed and the following season the amount of damage done by them was insignificant.

Fall plowing is often a desirable procedure in cotton culture whether the Boll Weevils are present or not, and so it seems that this pest, like so many others, will bring about an improvement in agricultural methods.

\section{OBSERVATIONS FOR PUPILS}

\section{Plum Curculio}

A

I. Pick up some green plums from beneath the trees. Can you find any of the crescent-shaped marks where the Curculios have laid their 
eggs? Can you find any holes where the Curculios have been simply feeding?

2. Cut open some of the fallen plums. Can you find eggs or larve in the green pulp? Can you trace the holes made by the larva in burrowing through the pulp?

3. Place a few freshly fallen plums on two or three inches of garclen soil in the bottom of a glass jar or a wooden box. A week later see if you can find any larva or pupe in the soil. Leave some of them and see if you can rear the adult beetles.

4. Hold a sheet or a large piece of paper under a plum tree and jar the limbs above. See if you can get any of the Curculios in this way. You may know them by their hard shells and curious snouts. Place a few of them under a bell glass with a branch of green plums held in a bottle of water. Watch the beetles eating and ovipositing.

5. Examine peaches, cherries, apples, and pears to find similar injuries of the Curculios. Do you find any live Curculio larve in green apples and pears?

I. Write or tell a little story with this title: The Life of the Plum Curculio. Follow this outline :-

The beetle in winter.

The beetle in spring.

The laying of the egg.

The hatching of the egg.

The growth of the larva.

The change to the pupa.

The change to the adult.

Remedies for injuries by Curculios.

2. Make some or all of these drawings: A plum showing feeding holes and crescent holes; a section of an injured plum with larva inside; an apple or a peach injured by Curculios.

3. Read Circular 73, U. S. Bureau of Entomology.

\section{May BeEtles}

I. Have you ever seen white grubs in the soil turned over in plowing or spading ?

2. Are these grubs more likely to be found in sod land than in that which has been cultivated for several years? 
3. Did you ever see the fully developed beetles in freshly plowed ground? At what seasons are they found?

4. Collect some of the beetles that fly about during the evenings in May or June. Kill them in a cyanide bottle. Study their structure. How do they differ from grasshoppers?

5. When the beetles are thick, try putting a lantern outdoors orer a tub of water with a bit of kerosene on top. See how many beetles are killed in this way. Write or tell the story of the life history of the May Beetle. Make some drawings to illustrate the story.

\section{Cotton Boll WeEvil}

I. If you live in a cotton-growing region, find out whether the Boll Weevil is present. If so, learn how long since it first appeared in your locality.

2. See what stages of the weevils you can find.

3. Look especially in cotton fields in fall to see whether any of the pests are hibernating there.

4. Learn what methods of preventing injury by weevils have been adopted by the cotton growers.

5. Write a little story with this title: What I Know about Boll Weevils. Illustrate it with drawings.

6. Read the account of the Cotton Boll IVeevil in Farmers' Bulletin 344 .

\section{Rose CHAFER}

I. At what season do you find the first Rose Chafers ?

2. What plants do they attack most seriously in your region?

3. Are there extensive sandy lands near, where the larvæ may develop?

4. Why is it probable that few birds would eat these beetles?

\section{Other Beetles}

Read such of the following references as your teacher directs :-

The Corn Rootworms, Circular 54, U. S. Bureau of Entomology. The Clover Root-borer, Circular 67, U. S. Bureau of Entomology. The Colorado Potato Beetle, Circular 87, U. S. Bureau of Entomology. The Fruit-tree Barkbeetle, Circular 29, U. S. Bureau of Entomology. The Larger Apple-tree Borers, Circular 32, U. S. Bureau of Entomology. 


\section{CHAPTER XI}

\section{Hymenoptera : the Ants, Bees, Wasps, and Sawflies}

THE ants, bees, wasps, and sawflies, with other related insects, form one of the most characteristic of all the orders. It is called Hymenoptera, and its members may be known by the fact that they pass through complete transformations, and that the adults generally have four more or less transparent membranous wings, of which the front pair is the larger. The mouth parts are formed for biting, but there is commonly present also a tongue by means of which the insects can suck or lap up liquids. In the case of the higher members of this order, the larvæ feed upon a special food prepared by the adults.

\section{SAWFLIES}

As very few of the Hymenoptera feed on plant tissues, a comparatively limited number of injurious species are found in the order. Of these the most important belong to the great family of Sawflies (Tenthredinidæ) which are characterized by having an ovipositor by means of which the insects are able to cut holes in vegetable tissues for the insertion of their eggs. The

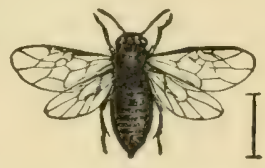

Cherry SAWFLY Magnified eggs are commonly laid within such cavities, but sometimes they are deposited along the outer surface of leaf or stem. They soon hatch into caterpillar-like larvæ, commonly called false caterpillars or slugs, which feed upon the foliage and finally spin cocoons within which they change to 
pupxe, and change again later into adult sawflies. The sawfly larva have three pairs of true legs and six to eight pairs of prolegs. Most of them have the abdomen curved

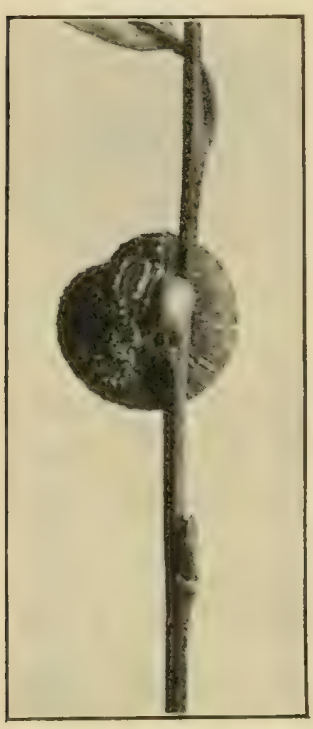

IVILLOW SAWFLY LARVA inward in the curious way shown in the picture of the Willow Sawfly larva.

The Common Currant Worm is one of the most familiar of the sawflies, and its life history fairly illustrates that of many related species. The small whitish glassy eggs are deposited in spring upon the principal veins of the under side of the lower leaves of currants and gooseberries. In about ten days these eggs hatch into small whitish grubs or larvæ that eat circular holes in the leaves. After a few days they cast their skins or molt - a process that is repeated several times during the next six weeks. In color they change from whitish to plain green, but soon become dotted with black, a color condition that continues until the last molt, when they change to light green with a little yellow on some parts of the body. As they grow older the injury to the leaves increases, and in severe attacks the bushes are completely defoliated.

When fully grown in the larval stage, the Currant Worms descend to the ground, seeking shelter beneath the leaves and rubbish. There they spin tough, brown, silken cocoons within which they change to pupæ. A short time later they again change to four-winged flies. These come forth early in summer and deposit eggs for a second brood of larvæ, most of which pass the following winter within their cocoons.

The eggs of the Currant Worm, small as they are, are 
infested by a tiny parasite that develops in them. An exceedingly minute fly deposits its eggs within the eggs of the Currant Worm - one in each. The former hatch into tiny footless larva that develop at the expense of the material of the Currant Worm egg. Finally these larvæ pupate and later change to tiny adult flies.

This Currant IVorm was originally a native of Europe, having been introduced into America many years ago. Its injuries may be prevented by spraying or dusting the bushes with hellebore when the larva are young. It should not be applied when the fruit is ripening.

In addition to the Currant Worm, there are a number of other insects belonging to this group. A very similar species feeds upon the foliage of raspberries and is called the Raspberry Sawfly. Another feeds upon strawberry leaves and is called the Strawberry Sawfly. Still another, which is an unusually large species, feeds upon willow and is called the Willow Sawfly. A very characteristic form often injures grape leaves and is sometimes called the Grape Slug.

Two similar and characteristic sawfly larvæ are found upon pears, plums, and cherries, and upon roses. These have in their younger stages curious slimy skins and eat only the surface of the leaves, causing a characteristic and easily recognized injury. The presence of this slimy coating enables one to kill them reacily by applying almost any fine powder, such as road dust or air-slaked lime tn the affected foliage. The particles will adhere to the larvæ and eventually cause their death.

Most of these false caterpillars are marked in colors of striking contrast which indicate that they have some method of defense from birds. They are thus examples of what the naturalists call warning coloration, and they seem to 
be comparatively little injured by birds. All of them, however, are easily destroyed by spraying with arsenical poisons or even with insect powder or hellebore.

\section{Four-IVinged Gallflies}

The next most important group of injurious insects belonging to the Hymenoptera is that of the Gallfies (Cynipidæ). There are many species of these insects which affect almost every sort of tree, shrub, and herbaceous plant, but comparatively few of them are destructive to cultivated crops.

One of the most familiar of these injurious insects is the species that makes its home in blackberry canes, causing a large abnormal swelling upon the cane which is commonly called the pithy Blackberry Gall. The small four-winged Gallfly deposits its eggs in the growing stem, a large number of eggs being placed near together. These hatch into tiny larva which bring about an abnormal growth of the blackberry tissues that eventually takes the form of the curious gall. If you cut one of these open, you are likely to find a great many little cells in which the larvæ are living. They finally transform to pupæ within these cells, and emerge later as adult flies. The cutting and burning of all affected stalks in winter will help to check the increase of these insects.

A great many forms of Gall insects may be found at almost any time upon the willows and the oaks. The familiar oak apples are excellent examples of the sort of abnormal vegetation growth caused by the Gallflies.

\section{Chalcid Flies}

The great family of small parasitic flies, called the Chalcid family, consists for the most part of insects that live in their 
larval stages upon other insects. A very few, however, develop at the expense of vegetable tissues. The Wheat Jointworm, of the genus Isosoma, is the most notable example of the latter. The adult of this is a small fly which deposits its eggs in the wheat stem at or near a joint. The egg hatches into a tiny footless larva, which absorbs the sap of the plant, causing the tissue to harden and the growth of the wheat to be injured. The larva finally matures into a pupa and again into an adult fly. When it is present in large numbers, it may seriously injure the wheat crop, but it is comparatively easily destroyed by any procedure that causes the destruction of the stalks containing larvæ or pupæ. The burning of the wheat stubble is one effective remedial measure.

\section{OBSERVATIONS FOR PUPILS}

\section{IMPORTED CURRANT WORM}

I. In spring or summer examine the leaves of currant and gooseberry bushes carcfully for the eggs upon the under side of the midrib and secondary veins. Do you suppose all the eggs on one leaf are deposited by one sawfly?

2. If you find any leaves with eggs upon them, place the leaf in a vivarium with the stem inserted in a bottle of water. Watch for the hatching of the larvæe, and feed them freș leaves from day to day.

3. Look at the lower leaves on the currant bushes to find some with round holes in them. Are there any currant worms at work on such leaves?

4. Raise a few currant worms in a jelly glass or other vivarium. Note the changes of color from time to time. Can you find the cast skins after molting? Do the caterpillars stop eating and rest before and after molting? Where does the skin split open before it is cast off ?

5. Examine carefully the legs on a good-sized currant worm. Are they all alike? Which are more pointed? How many legs in all ? Watch the insect as it crawls, and notice how the legs are used.

6. When the larva spin their cocoons, notice the texture of these. 
Is it like the texture of a moth cocoon? Are they water-tight ? Can you find any cocoons out of doors beneath infested currant bushes ?

7. Cut open a cocoon in which the insect has pupated and find the pupa and the cast skin. Compare this pupa, especially in regard to the distinctness of the legs and other appendages with the pupa of a moth or butterfly.

8. Observe how the fly escapes from the cocoon. Does it gnaw off a cap ? Compare it with a bee or a wasp and then with a two-winged fly. Study its structural characters.

9. Give either orally or in writing a short account of the life of the Currant Worm. 'This outline may help:-

The laying of the eggs.

The hatching of the eggs.

The growth of the caterpillar.

The spinning of the cocoon.

The change to the pupa.

The change to the adult fly.

Io. Make these drawings: A leaf with round holes made by young larva; leaf badly eaten; a larva, side view; a cocoon; an adult sawfly.

\section{OTHER INSECTS}

Read such of the following references as your teacher may direct:-

The Joint Worm, Circular 66, U. S. Bureau of Entomology. Insect Enemies of Growing Wheat, Farmers' Bulletin, 132. 


\section{CHAPTER XII}

\section{Insecticides and their Application}

IT is well known that there are two principal ways in which plant-feeding insects get their food. Some insects bite or chew the parts of the plants upon which they feed, while others are provided with a hollow beak that they push into the tissues of the plant to suck the sap. All the leaf-eating caterpillars are examples of the biting insects, while the plant lice, squash bug, and many related species are examples of the sucking insects. The picture below shows the way in which the sucking mouth parts of the plant louse are inserted among the cells of plant tissues.

This essential difference in the feeding habits of insects must be considered when we try to kill them by the application of insecticides. In the case of a biting insect, we may hope to poison it by placing fine particles of arsenic in some form upon the leaves of the food plant. As the insect bites the leaves, it will be likely to eat some of these particles and be killed. But in the case of a sucking insect, we must use some insecticide that will kill by coming in contact with the insect itself. Such insecticides commonly act by reaching the interior of the insect through the breathing pores, or trachce,

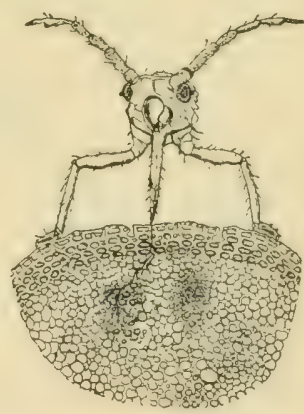

HEAD OF APHIS SHOWING SUCKING TONGUE AMONG PLANT CELLS Magnified and so they are sometimes called tracheal poisons to distinguish them from the ordinary internal poisons. Kero- 
sene, whale-oil soap, and pyrethrum or insect powder are among the most important tracheal poisons.

Some plant-feeding larvæ have such slimy skins that they are readily killed by dusting with powdered air-slaked lime, or ashes. The "slugs" on pear, cherry, and rose leaves are examples of these.

\section{InTERnAL PoIsons}

The poisons most commonly used against biting insects are certain chemical compounds composed in part of arsenic. Arsenate of lead, arsenite of lime, and Paris green are notable examples of such insecticides.

For a long time Paris green was the most important of the arsenical insecticides. It is a chemical combination of arsenic and copper, containing, when pure, about fifty-five per cent of arsenic. It is in a finely powdered condition, and, when placed in water, the fine particles do not dissolve, but remain in suspension. Because of this fact, one of the most popular ways of applying arsenical poisons to

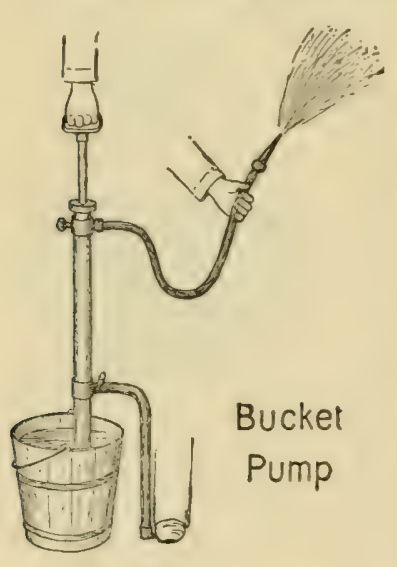
plants in danger from the attacks of biting insects, is in a water mixture by means of a force pump and spray nozzle.

In its simplest form this process consists of mixing about a teaspoonful of the poison in a pail of water, stirring thoroughly to get the powder evenly distributed through the water. A small force pump, to which is attached a rubber tube with a spray nozzle at the end, is then set in the pail. By working the handle of the pump, the water with the poison particles in suspension is forced through the tube and nozzle, com- 
ing from the latter in a mistlike spray. This spray is directed upon the leaves of the plant to be protected, covering each leaf with the liquid.

As soon as the spraying ceases, the water begins to evaporate and rapidly disappears, leaving the particles of poison more or less evenly distributed over the foliage. There they remain for some time, so that in case a biting insect feeds upon the poisoned surface it will eat some of these particles and be killed.

Fortunately the insoluble poison is not absorbed into the tissues of the plant, so that the process can generally be carried on without danger to the consumers of the crop. In the course of a few weeks the particles of poison are washed away by rain or dew, or blown away by the wind, or dissipated through the action of the sunshine.

A substance that is used to destroy insects is called an insccticide or insect killer. Thus Paris green is an insecticide. So also is lead arsenate, hellebore, powdered tobacco, and insect powder. Each of these substances may be applied to plants in mixture with water, or most of them may be dusted on in the form of a dry powder. One may sometimes use for this purpose simply a porous bag, out of which the powder is sifted. It is better, however, to apply the material by means of one of the many kinds of powder bellows manufactured for this purpose. With one of the better forms of these, a pound of Paris green can be evenly distributed over an acre of potato vines.

Paris green is so powerful a poison that it is often desirable to dilute it with some substance like land plaster, air-slaked lime, or flour. The proportion of poison to diluent varies greatly with different users. One part of poison to twenty parts of diluent serves the purpose if the mixing 
be thoroughly done. When a good powder gun is used, it is not so necessary to dilute the poison.

During recent years, arsenate of lead has become one of the most generally used of arsenical insecticides. It is made by combining arsenate of soda with acetate of lead in water, and is commonly offered for sale in the form of a thick paste. This insecticide has a great advantage over Paris green in that it may be applied even to tender foliage

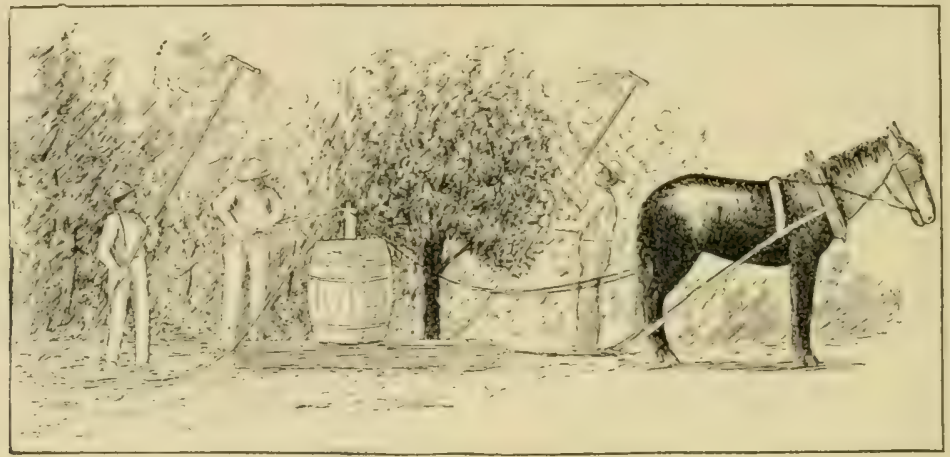

A Simple Spraying OUTFit

without injury to the plant. It also remains upon the leaves longer than any other arsenical insecticides. Under special conditions it may be advisable to prepare the arsenate of lead at home, but usually this is scarcely worth while. A dry, powdery form of this poison has lately been put upon the market, and is likely to be very useful for applying with various sorts of powder bellows.

Trouble has been observed in some IVestern states in injury to the health of trees from the use of arsenate of lead. The poison appears to penetrate the soil and be absorbed through the roots. On this account arsenic sulphide has been substituted in an experimental way, and promises to become an important insecticide. It is less soluble than other forms of arsenic, and also less expensive. 


\section{External Poisons}

The petroleum oils are among the most important of the contact-killing insecticides. For general use kerosene is the most convenient of these oils. As kerosene does not mix with water, dilution with this liquid is not practicable. It has been found, however, that kerosene may be safely and effectively used, provided it is first emulsified with hot soapsuds. This is generally accomplished by adding two gallons of kerosene to one gallon of a solution made by dissolving half a pound of common hard soap in one gallon of boiling water, and then churning the mixture by forcing it back into the same vessel through a force pump. A creamy emulsion will thus be formed. Before it is applied, this emulsion is to be diluted with nine or ten parts of water. It is better to use soft water or rain water for the dilution.

The undiluted emulsion may be kept for some time, stored in a dark, cool place. When needed, the required amount may be measured out and mixed with three or four parts of boiling water, cold water being added to fill out the dilution.

Kerosene emulsion is an excellent remedy for insects that suck the sap of plants through pointed beaks, such as the plant lice and the chinch bugs. It kills by contact, but does not remain upon the plant in an effective condition. It is applied in a fine spray.

Various forms of crude petroleum have recently come into use against scale insects. Some proprietary insecticides contain heavy oils so treated as to mix readily with water, so that they are very easy to spray upon dormant trees.

The lime-sulphur wash is one of the most efficient con- 
tact-killing insecticides. It is used chiefly on dormant trees to kill the San José scale and other scale insects. The usual formula is: Unslaked lime, 20 pounds; sulphur, I 5 pounds; water, 50 gallons. The lime is slaked in Io or I 5 gallons of water; then the sulphur is added and the preparation boiled for an hour. The rest of the water is then added and the mixture is ready for use on dormant trees only.

In place of this mixture boiled by outside heat, lime-sulphur washes have lately been made by utilizing the heat of the slaking lime. These are called self-boiled mixtures and usually have less sulphur and lime than the formula given above. They are often used for summer spraying, being effective against both scale insects and various fungous diseases.

Strong soapsuds have a decided insecticide value for us€ against plant lice and other soft-bodied insects. Whale-oil soaps are more effective than ordinary soaps, and are generally used as insecticides.

Pyrethrum powder commonly sold as insect powder is a standard insecticide for use against house flies and certain other insects. It consists of the powdered flowerheads of the pyrethrum plants - a genus of composite flowers which are often grown in gardens for their ornamental value. This powder is generally used dried, but may be applied as a spray - by mixing one ounce of powder with two gallons of water and letting it stand over night, or by boiling for a few minutes.

Tobacco is another contact-killing insecticide which is frequently used with good results against plant lice and vermin on domestic animals. The refuse stems are sometimes utilized in greenhouses as a mulch for growing crops to prevent the development of aphides. These stems are 
also ground into a powder which is applied directly to the insects. A tobacco decoction is frequently made by boiling the powder or stems in water or by pouring boiling water over them. There is thus formed a concentrated solution which is diluted with cold water until there are about two gallons of decoction for each pound of tobacco used. The decoction may be sprayed upon the insects to be killed. Per-

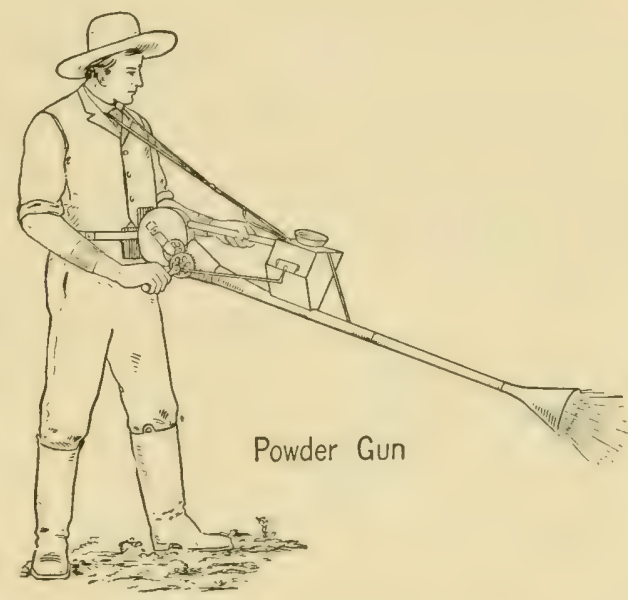
haps the way in which tobacco is most commonly used as an insecticide is that of slowly burning the stems in greenhouses, producing a smoke which permeates the plants and kills the pests upon them.

\section{VAPORS AND GASES}

There are certain insects which may most easily be killed by the use of vapors or gases. For this purpose bisulphide of carbon and hydrocyanic acid gas are chiefly employed. The former is a liquid that readily volatilizes on exposure to the air and kilis all insects with which it comes in contact. It is used to best advantage against insects affecting dry seeds and grains in storehouses, and against insects affecting the roots of plants.

Hydrocyanic acid gas is a deadly vapor made by pouring sulphuric acid on cyanide of potassium. It is used to destroy white flies in greenhouses and for various enemies of citrus fruits in Florida and California. In the case of 
these fruits, tents are placed over the trees before the gas is generated.

In California sulphur is used as a remedy for red spiders and certain leaf hoppers. The sulphur vaporizes in the hot sunshine, and the fumes are fatal to the insects. In greenhouses sulphur is also used by painting heating pipes with it so that the fumes will be given off.

\section{OBSERVATIONS FOR PUPILS}

r. Make a list of the injurious plant-feeding insects that you know which may be killed by internal poisons.

2. Make a similar list of those that may be killed by tracheal poisons.

3. What insects in your locality must be killed by the use of noxious gases?

4. In what ways have you seen insecticides applied?

5. Read such of these references as your teacher may direct:-

Important Insecticides, Farmers' Builetin I27. Carbon Bisulphide as an Insecticide, larmers' lsulletin I $_{45}$. Spraying for Orchard Insects, Yearbook Reprint 480. 


\section{CHAPTER XIII}

\section{The Predaceous Insects}

While a large proportion of the insects that we meet in our walks afield are in one way or another injurious to cultivated crops or domestic animals, there are vast numbers of species which may be regarded as either beneficial or neutral. From the beginning of their lives as eggs until their death as adults, the injurious insects are beset by a multitude of enemies. Some of their enemies attack

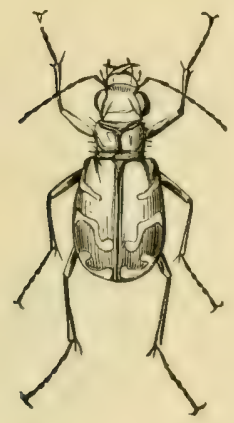

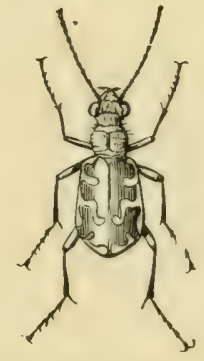

TIGER BEETLES

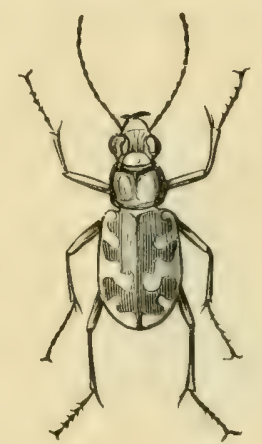

them with wide-open jaws, devouring the victims bodily, while others pierce their bodies with pointed beaks to suck their lifeblood. Yet others insert lancelike ovipositors by means of which they leave inside the body of the victim tiny eggs that develop into parasitcs whose attacks are as fatal as those of the larger foes. Those insects that devour the bodies or suck the lifeblood of their victims are called Predaceous Insects.

There are a great many different groups of predaceous insects belonging to many families in various orders. 
There is room in these pages for a discussion of only a few of the more important of these groups.

\section{Predaceous Beetles}

Among the notable foes of injurious insects the Predaceous Ground Beetles (Carabidæ) hold a high rank. They are active, voracious beetles, having hard, flattened bodies, strong legs, and large jaws. They hunt commonly upon the ground or in trees and shrubs for caterpillars and other insects that may serve as food. Cutworms, army worms, gypsy moth caterpillars, and similar grass and leaffeeding larvæ are especially likely to be caught by them.
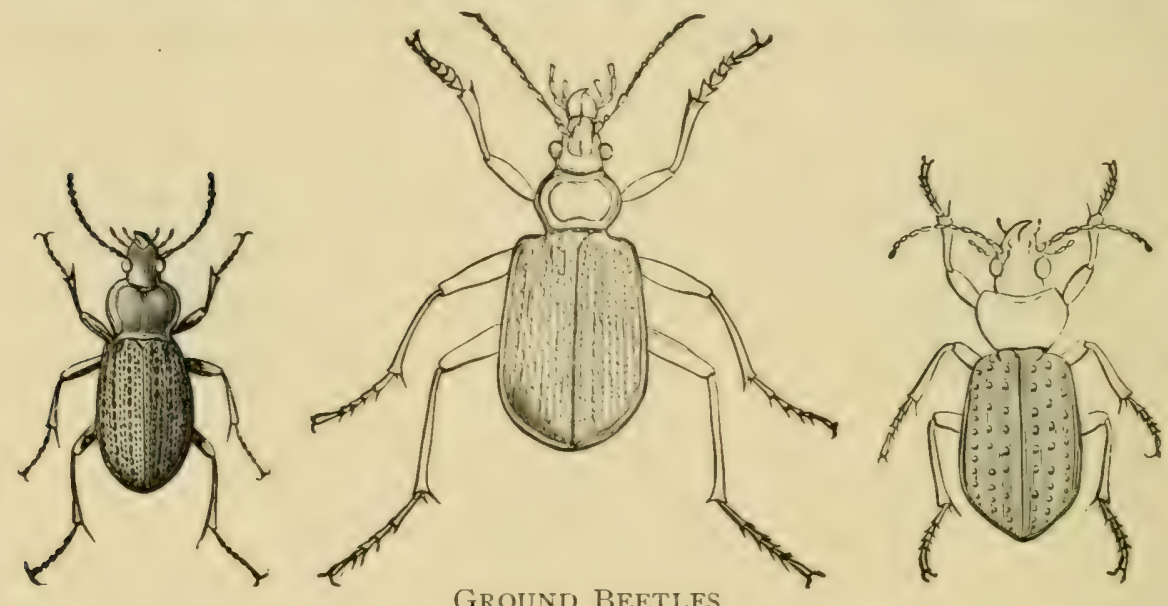

Ground BeEtles

Many Ground Beetles are black in color, but a few are greenish blue, and some are marked with golden spots. Specimens are nearly always to be found beneath boards or logs lying loosely on the soil surface.

The larvæ of most of these ground beetles are also predaceous. They are very active, and are provided with large jaws for catching and devouring their prey.

The Tiger Beetles (Cicindelidx) are perhaps of less economic importance than the Ground Beetles because they 
hunt their prey in a more restricted range. Tiger Beetles are to be found in open sunny spaces, as along highways and byways, or on the sandy shores of lakes and streams. They greedily devour such insects as they find in their eager wanderings. The long legs are fitted for rapid running; the large eyes are fitted for seeing over a wide area; the strong jaws are fitted for sudden grasping, and the well-developed

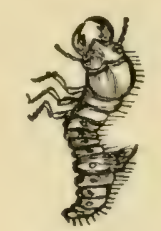

TIGER BEETLE LARVA wings are fitted for quick flight on the approach of danger. The wing-covers, legs, and body wall are very hard and often brilliantly colored in metallic hues.

In early life the Tiger Beetles are curious grublike larvæ that live in burrows in hard ground, as along beaten paths and sandy shores. These burrows are vertical holes, nearly as large as the diameter of a lead pencil. The larvæ have a strangely flattened head with long, widespreading jaws. Each lies in wait at the top of the burrow, practically invisible on the smooth surface of the ground. When an unsuspecting caterpillar or other insect passes over the waiting head, the jaws grasp the victim, which is quickly dragged into the burrow to be devoured at leisure.

From an economic point of view the familiar little Lady-

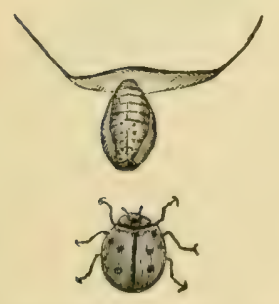

LADYBIRD BEETLE AND PUPA bird Beetles (Coccinellidæ) are perhaps the most important of all the predaceous beetles. These brightly colored little creatures, in both their larval and adult stages, feed chiefly upon the destructive aphides or plant lice, destroying every year billions of the pests.

Wherever you find a colony of aphides sucking the sap from living plants, there you are likely to find some of the Ladybirds at work. They lay their eggs 
on leaves or stems, the eggs of the larger sorts bearing a general resemblance to those of the familiar Colorado potato beetle. These eggs soon hatch into the curious Ladybird larvæ which also feed upon the aphides, destroying

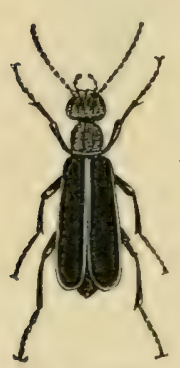

BLISTER

BEETLE great numbers of them. After some weeks of feeding, the Ladybird larvæ attach themselves to leaf or bark and change to pupæ, soon to change again to adult beetles.

While most of our common Ladybird beetles feed chiefly upon aphides, some species devour bark lice. One of the most noted kinds of beneficial insects is the celebrated Australian Ladybird - Vidalia cardinalis. This insect was introduced into California to destroy the fluted scale-a destructive pest in orange groves. The experiment was quite successful, for the scale insects were materially checked by their little foes.

\section{Predaceous Bugs}

Probably the most important predaceous insects in the order of true bugs are the Soldier Bugs (Pentatomidæ). These belong to the genus Podisus; they are of moderate size, the larger common ones being slightly less than an inch long, with flattened bodies, well-developed legs, and strong,

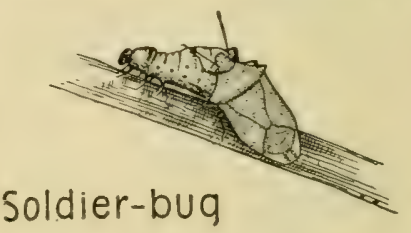
sharply pointed beaks. There are about a dozen species, several of which have a horizontal spiny projection on each side of the back behind the head.

The Spined Soldier Bug is one of the largest and most widely distributed of these insects. The adults pass the winter under loose bark, fallen trees, loose leaves, or other shelter. In spring they come forth and attack such cater- 
pillars or other soft-bodied insects as they can find, sucking their lifeblood greedily. They lay the rather large, more or less barrel-shaped eggs in clusters upon leaves or bark. The eggs soon hatch into tiny bugs that at first get food by sucking the sap of various leaves or tender stems.

During the next few weeks these young Soldier Bugs molt several times, increasing in size each time. The time when they stop sucking the sap of plants to begin upon the blood of animals seems not to be known, but it is probably when they are about half grown. During the rest of their lives they seem to prefer animal juices to those of plants, and go eagerly about in search of victims. Among the most important of these are the larvæ of the Colorado potato beetles, asparagus beetles; cabbage worms, web-worms, tussock caterpillars, cotton worms, leaf rollers, codling moth larvæ, sawfly larvæ, and even the curious walking sticks.

This or a closely related Soldier Bug is one of the commonest predaceous enemies of the tent caterpillars, occurring frequently in the nest of the American tent caterpillar.

While the Soldier Bugs, as befits their name, are bold freebooters, constantly invading new areas in search of victims, the Ambush Bugs (Phymatida) have quite a different habit. These take up their quarters in flowers or other shelter where they patiently lie in ambush until some unsuspecting insect comes within reach of their curiously made, grasping arms. As soon as it has seized the victim, the pointed beak serves to suck out the body juices, and the remains are cast aside.

Five species of Ambush Bugs are recorded for our region. Only one of these is so abundant and widely distributed as to be generally known. It may be called Wolff's Ambush Bug and is in color a curious mixture of green and yellow. 
It is especially likely to be found in yellow flowers, waiting to capture unsuspecting butterfly visitors.

The Wheel Bug is a common predaceous insect in the Southern states. It is of good size, being more than an inch long, with a sharp beak and a curious crest on the thorax that gives it its common name. It feeds largely upon caterpillars, and belongs to the family of Assassin Bugs (Reduviidæ).

\section{Two-winged Flies}

Of the great number of families of two-winged flies comparatively few are predaceous. The most distinctive of these are the Robber Flies (Asilida), a group of hawklike creatures, some of which may often be seen in open fields.

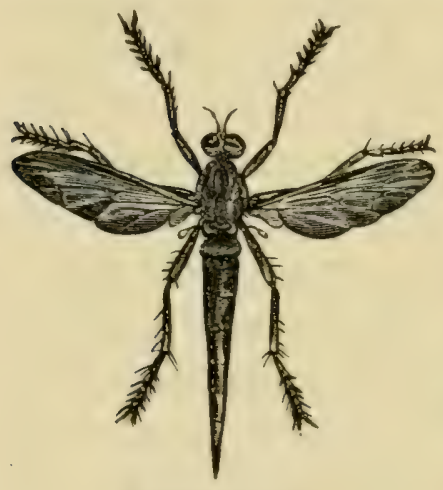

ROBBER FLY

Nearly a thousand distinct species are found in North America. The more familiar forms have powerful wings and long legs and abdomen. They commonly rest on low shrubs or plants whence they can readily pounce upon any flying insect that passes near. Honeybees are so often killed by them that in some regions these flies are called bee killers. Such victims are caught by the powerful legs, and quickly sucked dry by the voracious robbers. A few species bear a striking resemblance to bumblebees and wasps, from which they are at once distinguished by having but one pair of wings.

So far as their earlier stages have been described, the larvæ of these flies seem to be largely predaceous also. They live in damp soil and rotting wood, apparently feeding upon the other insects found in such situations. 
A colony of aphides or plant lice offers many opportunities to study the relations of various groups of insects to one another. In such a colony there are forms of winged and wingless aphides as well as several kinds of enemies that attack them. Among the latter are the tiny fourwinged parasites, the young and adult ladybird beetles, and the strange Aphis Lions. In addition to these, you can generally find, also, a curious footless grub blunt at one end and sharply pointed at the other, which impales the plant lice one at a time on its pointed end, sucks the lifeblood, and casts aside the empty skins. These are the larvæ of the Syrphus Flies (Syrphidre), many species of which in the larval state thus prey upon the aphides.

The Syrphus Flies are generally a little larger than the common house fly and may be found in abundance visiting flowers in search of pollen and nectar. The mother flies lay their elongated whitish eggs on leaves and bark amid colonies of plant lice. The eggs shortly hatch into the curious larvæ that prey upon the aphides. When full grown, the syrphid larvæ change to pupæ, still upon

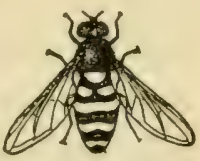

SYRPHUS

FLY the leaf or bark, and change again a little later into adult flies.

\section{Four-Winged Flies}

The great order of Four-winged Flies - Hymenoptera contains several families that may be classed to a greater or less extent in the predaceous group. One of the most important of these is that of the Ants, which are so universally distributed over the surface of the earth. Most of these ubiquitous little creatures have a wide range of food, taking almost anything, living or dead. There is no doubt, however, that they are important foes of noxious insects, de- 
stroying unsuspected numbers of eggs, larvæ, and later stages of plant-feeding insects.

The Social Wasps (Vespidæ) are well-known predaceous insects. The adults build paper nests in which the young are reared, being fed largely with various insects that the worker wasps catch for them. These workers also feed

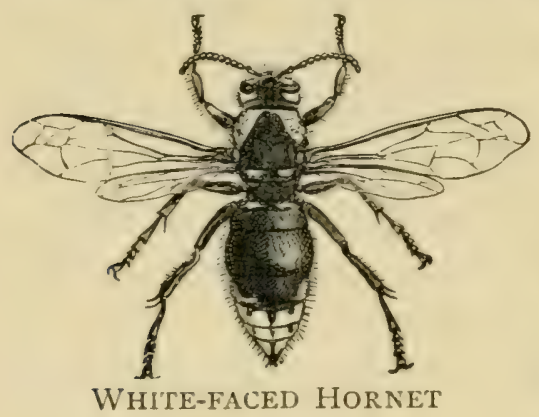

WHITE-FACED HORNET freely upon such insects, though they also eat the nectar of flowers and other kinds of food.

The various groups of Solitary Wasps mustalso be classed with the predaceous insects, though their peculiar habits ally them in a way with the true parasites. The Mud Wasps and the Digger Wasps provision their cells and burrows with flies, grasshoppers, caterpillars, spiders, and other creatures. These victims are paralyzed by the sting of the wasp so that they lie helpless in the cell in which the wasp egg is laid. This egg soon hatches into a larva that feeds upon the paralyzed prey, finally transforming to a pupa and later to an adult wasp.

\section{OTHER ORDERS}

Comparatively few important predaceous families are found in the other orders of insects. Some of these, however, are friendly insects of great value, serving a notable purpose in the economy of nature.

What the swallows are among the birds, the Dragon Flies are among the insects. These powerful creatures are wonderfully adapted to their life work. With enormous eyes that see in practically all directions, with powerful wings that carry them with lightning rapidity through the air, with 
a long abdomen that serves admirably as an aërial rudder, and with strong front legs and great jaws fitted for grasping and biting their victims, they may indeed appear as formidable dragons to less fortunate insects. In their earlier stages these insects develop in the water, where they are also predaceous.

The Dragon Flies are commonly divided into two groups: those in which the wings are held vertically when the insect is at rest are called Damsel Flies; those in which the wings are held horizontally when the insect is at rest are called Dragon Flies.

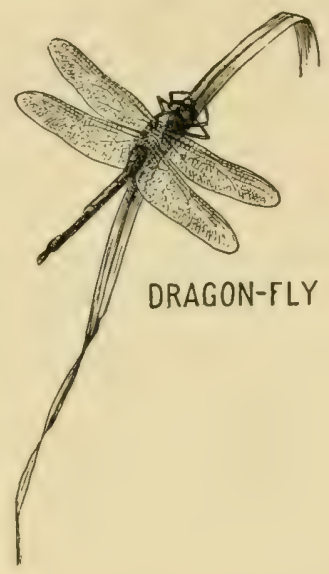

Among the many parasitic and predaceous insects to be found amid colonies of plant lice, the Aphis Lions are per-

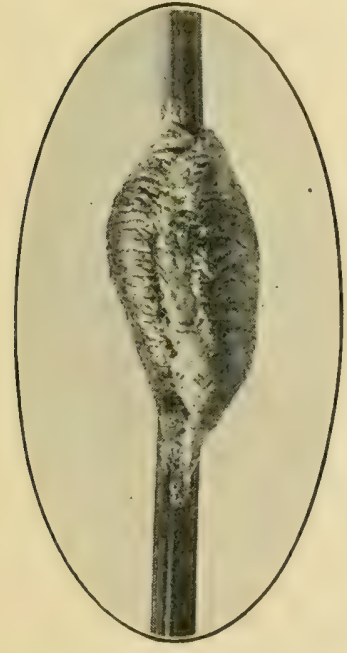

EGG MASS OF MANTIS haps the most remarkable. These are long-legged, slender-bodied creatures with strange long jaws between which they grasp their prey while they suck the body dry. They are the larvæ of the Golden-eyed Lace-winged Flies (Chrysopidæ).

The curious Mantids of the order Orthoptera are also remarkable predaceous insects. They are closely related to the walking sticks and lie in wait till various insects come within reach of their grasping front legs. The native Praying Mantis is not uncommon in the Southern states, while another species from Europe has lately been introduced into New York state. There are, of course, many predaceous creatures among 
the spiders, mites, and myriapods, related to the insects proper. But the limitations of space forbid their discussion here.

\section{OBSERVATIONS FOR PUPILS \\ Predaceous Beetles}

I. If you can find any of the Predaceous Ground Beetles, keep them alive in a vivarium for a few days. Furnish cutworms, cabbage worms, or other caterpillars for food.

2. See if you can find any Tiger Beetles along paths and roadsides. Which way do the beetles face when they alight - toward you or not? Catch two in an insect net. Keep them in a vivarium and furnish caterpillars for food.

3. See if you can find any burrows of Tiger Beetle larva in smoothtrodden ground.

4. Bring in a few Ladybird Beetles and keep in a vivarium. Furnish aphides for food. See if you can find any Ladybird larvæ, pupæ, or eggs.

5. For a fuller account of Tiger Beetles read Life Historics of American Insects, pages 19-27; of the Ladybird Beetles, Stories of Insect Life, Second Series, pages 49-55.

\section{Predaceous Bugs}

I. Look in tent caterpillars' nests in spring to see if you can find any Soldier Bugs. Or later in the season see if there are any on the potato vines. If you find any, keep them in vivaria for a few days and see the way they take their food.

2. In summer or early autumn sweep clusters of herbage for the yellowish Ambush Bugs. Study their structure to see the sharp beak and the curious front legs fitted for grasping.

3. If you live where the Wheel Bugs are found, keep one alive and watch it feed upon caterpillars.

4. Read the life story of the Wheel Bug in The Insect Book, pages $294-296$.

\section{Two-winged Flies}

I. On warm days look for the Robber Flies along sunny roads. Listen to the quick buzz as they fly up and watch how they lie in wait for prey. 
2. Examine a colony of plant lice carefully. Try to find the white eggs, the footless larvæ, or the curious brown puparia of some of the Syrphus Flies. Watch one of the larvæ through a lens to see the way it impales its victims.

3. Read the account of the Robber Flies in The Insect Book, pages I4I-I 43; of the Syrphus Fly in Stories of Insect Life, First Series, pages $50-5 \mathrm{I}$.

\section{ANTS AND WASPS}

I. Watch the surface of an ant's nest to see if any insects are carried to it.

2. Watch wasps and hornets as they fly about porches and near houses to see if they catch flies and other insects.

3. Open the cells of a Mud Wasp's nest to see the paralyzed spiders or caterpillars inside.

4. Watch the places where Digger Wasps make their burrows to see the insects at work.

5. Read such of the following accounts of the life histories of wasps as you have access to: -

The Insect Book, pages 18-30. American Insects, pages 490-510. Nature Biographies, pages 102-106. Life Histories of American Insects, 147-178. Stories of Insect Life, Second Series, pages 2.-29, or the book by Professor and Mrs. Peckham, entitled The Solitary Wasps.

\section{Other Predaceous Insects}

I. Watch the Dragon Flies and Damsel Flies in summer. Notice the position of the wings when the insects alight.

2. Read the account of Dragon Flies in American Insects, pages 7589; also the accounts of the Praying Mantis in The Insect Book, pages 326-328; Stories of Insect Life, Second Series, pages 63-68.

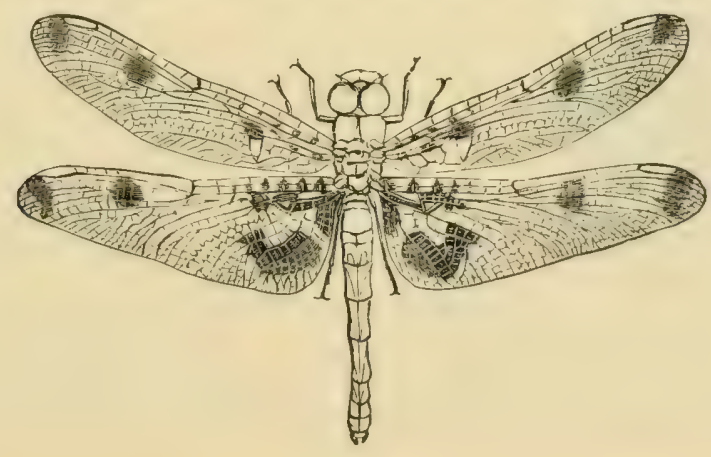




\section{CHAPTER XIV}

\section{The Four-winged Parasites}

IT is fortunate for mankind that almost all species of injurious insects have insect enemies that destroy them. These insect enemies are divided into two groups as regards the methods by which they kill their victims. There is no hard and fast line to be drawn between these groups, but in general we may safely say that the insects which destroy other insects are either parasites or predaceous insects. As a rule, the parasites develop in the larval state within the bodies of their victims, and, as a rule, the predaceous insects feed, sometimes during the earlier stages, sometimes during their adult stage, and sometimes during both, upon their vic-

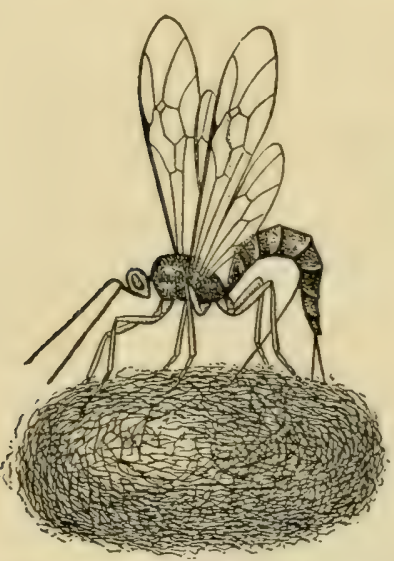

ICHNEUMON FLY OVIPOSITING IN COCOON tims, attacking them from the outside either by thrusting a pointed beak through the skin and sucking their lifeblood, or else by devouring them bodily.

\section{The Ichneumon Flies}

One of the most important groups of parasitic insects is that of the Ichneumon Flies. These are slender-bodied, more or less wasplike creatures, with four wings, long antennæ, and well-developed legs adapted for running. You may very often see them running rapidly over the surface of leaf or bark, in search 
of victims in which to lay their eggs, constantly vibrating their antennae. Occasionally, also, you may see them visiting such flowers as have the nectar freely exposed to lapping by their short tongues. Or you may see them in the evening as they fly about a light to which they are attracted.

The Ichneumon Flies vary greatly in size, form, and habits. Some are so minute as to be barely visible to the unaided eye, while others measure several inches in length, with. long antennæ and slender ovipositors extending behind the abdomen.

Among the largest of the Ichneumon Flies are the interesting brown insects called the Ophion Flies. The life his-

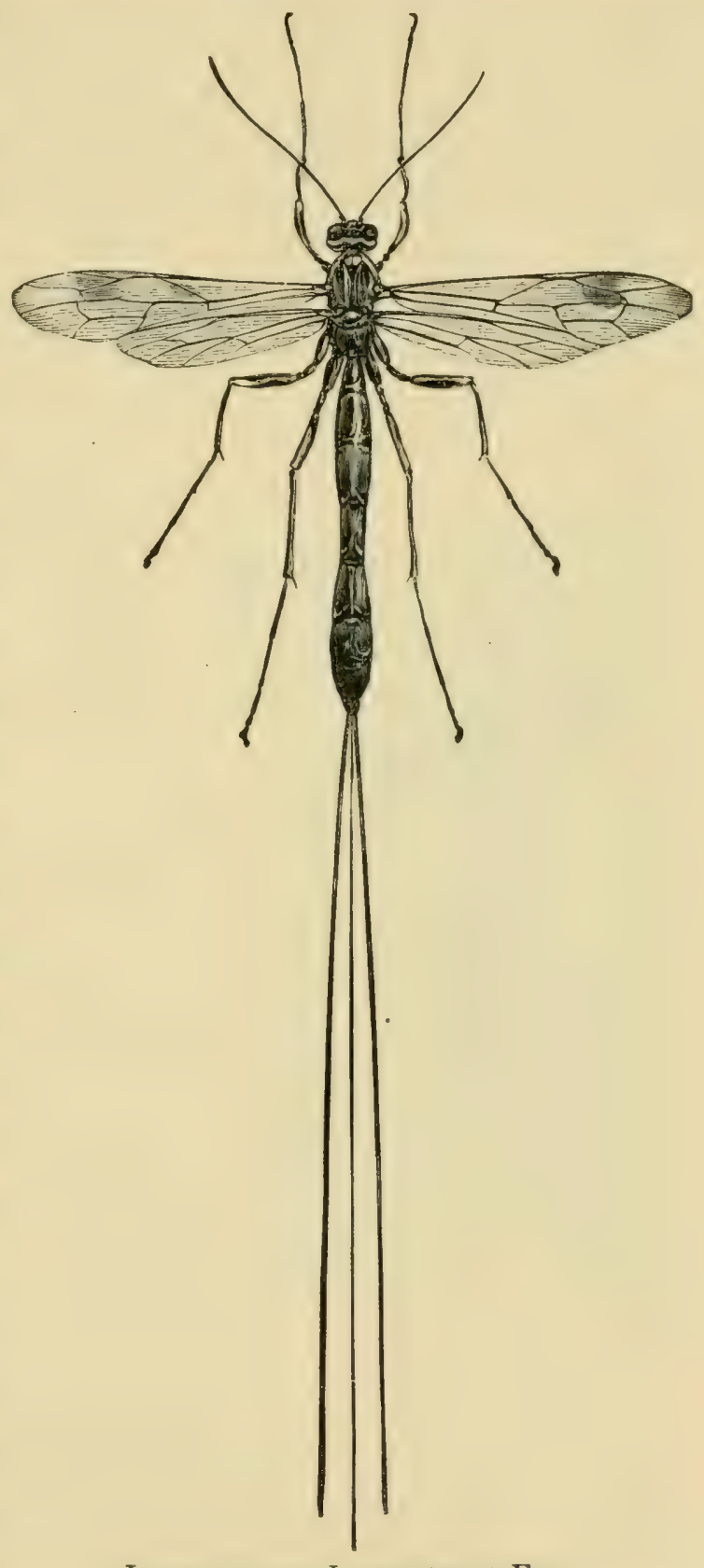


tory of one of these in brief is this: The adult fly deposits its egg within the body of a caterpillar, especially the caterpillars of the large silkworm moths, like the polyphemus moth or the cecropia moth. This egg shortly hatches into a small white footless maggot that absorbs the body juices of the host, as the victim is often called, but at first does not seriously interfere with its development. The - caterpillar with its enemy inside continues to feed and grow for some time. It is commonly able to spin its cocoon and perhaps change to a pupa within the cocoon before the larva of the parasite becomes so large as to kill the host. It does kill it, however, finally, and then within the protect-

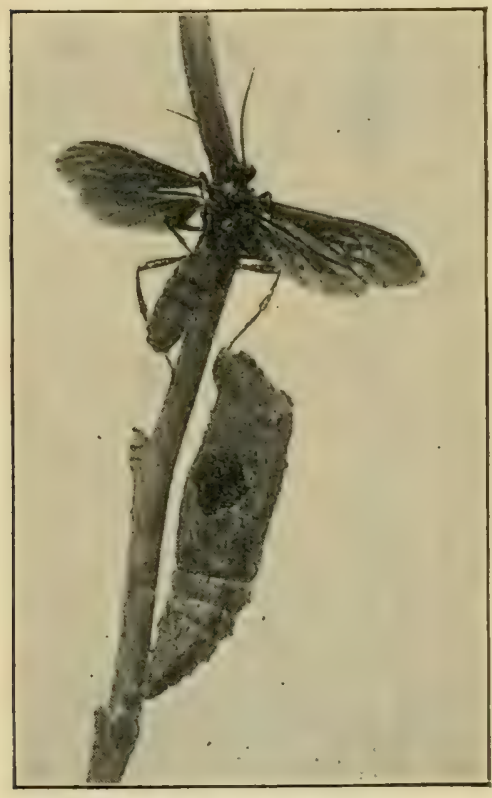

ICHNEUMON FLY ANI BUTTERFLY CHRYSALIS IN WHICH IT DEVELOPED ing shelter of the host's cocoon, the larva of the Ophion Fly changes to a chrysalis. The following spring it will change again to an adult fly, like the one that laid the egg in the caterpillar so many months before. This fly is provided with sharp jaws by means of which it gnaws its way out of the cocoon and flies freely about. It has thus completed the cycle of a parasite's life.

Sometimes the egg of the parasite is not laid within the caterpillar until after it has spun its cocoon. This is often the case with certain medium-sized Ichneumon Flies of the genus Pimpla. These may sometimes be seen standing upon the cocoons of the common apple-tree tent caterpillar, with the ovipositor thrust down through the cocoon in the manner 
illustrated on page I74. The egg develops within the body of the host into a white footless maggot that soon matures as a larva and changes to a pupa, which in turn shortly changes into an adult Pimpla.

Many of the Ichneumon Flies deposit their eggs within the burrows of larvæ that bore in the stems of herbaceous plants or the bark or trunks of shrubs and trees. In such cases, it evidently would be difficult for the mother parasite to find precisely the location of the burrowing larva, so she simply deposits her egg within the burrow of the latter, and the little larva that hatches from this egg is generally provided with some method by which it is able to reach its victim. Instead, however, of developing on the inside of its host, it usually simply attaches itself to the skin and
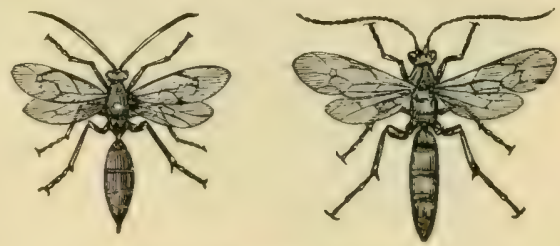

ICHNEUMON FLIES sucks its lifeblood from the outside. It finally kills the host, becomes full-grown as an Ichneumon larva, and changes first to a pupa, and a little later into an adult fly that is able to eat its way out through the bark of the plant.

\section{Microgaster . Flies}

One of the most abundant groups of the Ichneumon Flies is that of the Microgaster Flies. These are rather

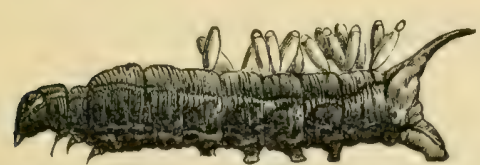

COCOUNS OF MICROGASTER FLIES

small insects that deposit their eggs in smooth-skinned caterpillars of many kinds. As a rule, each female fly is provided with a pointed ovipositor with which she can pierce the skin of the caterpillar to insert her eggs within its body. These eggs shortly hatch into tiny maggots that develop at the expense of the tissues of the un- 
fortunate host. In a few weeks the maggots become fullgrown, and then each burrows its way out through the skin

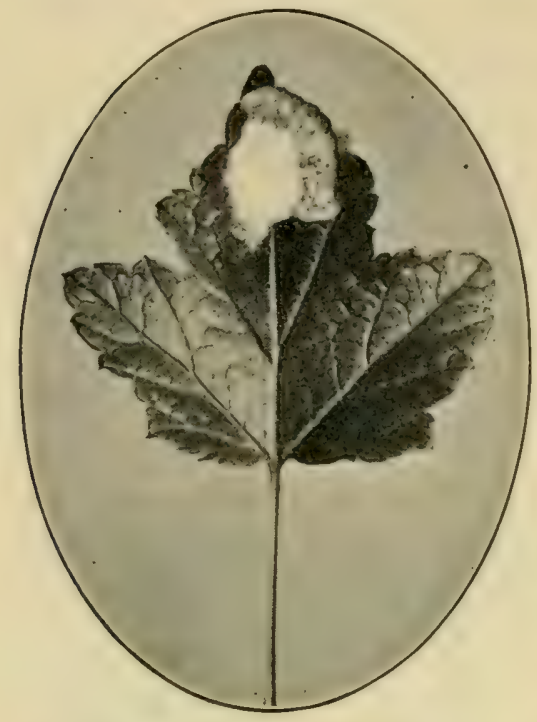

Caterpillar With COCOON MASS OF MICROGASTER PARASIT'ES

of the victim. Once outside, each maggot spins some sort of silken cocoon within which it changes first to a pupa, and later to an adult Microgaster similar to the one that laid the eggs.

There is much variation in the color, form, and arrangement of the cocoons of these Microgaster Flies. Some are white, others yellow. Some are formed singly, others side by side in a compact mass, and still others in a loose mass of fluffy silk.

There is also great variation in the number of parasites to a single caterpillar. Sometimes there is but one parasite to a host, as in the case of certain leaf miners, sometimes there are only a few, but more commonly there are a great many - several hundred in the case of the tomato worm and other sphinx caterpillars.

\section{Plant-louse Parasites}

Almost any colony of plant lice will furnish examples of the extremely interesting family of tiny flies that prey especially upon the aphides. These are little four-winged flies so small as to be barely visible to the unaided eye, which develop in their younger stages in the bodies of the plant lice, and cause the death of untold billions of these vexatious pests. 
A considerable proportion of these tiny parasites belong to the genus Aphidius. The fly generally deposits her egg within the abdomen of the aphid. The egg shortly hatches into a tiny footless maggot that lives within the body of its , host, absorbing the materials of growth from it, and often being visible while the host insect apparently is still alive. Fi-

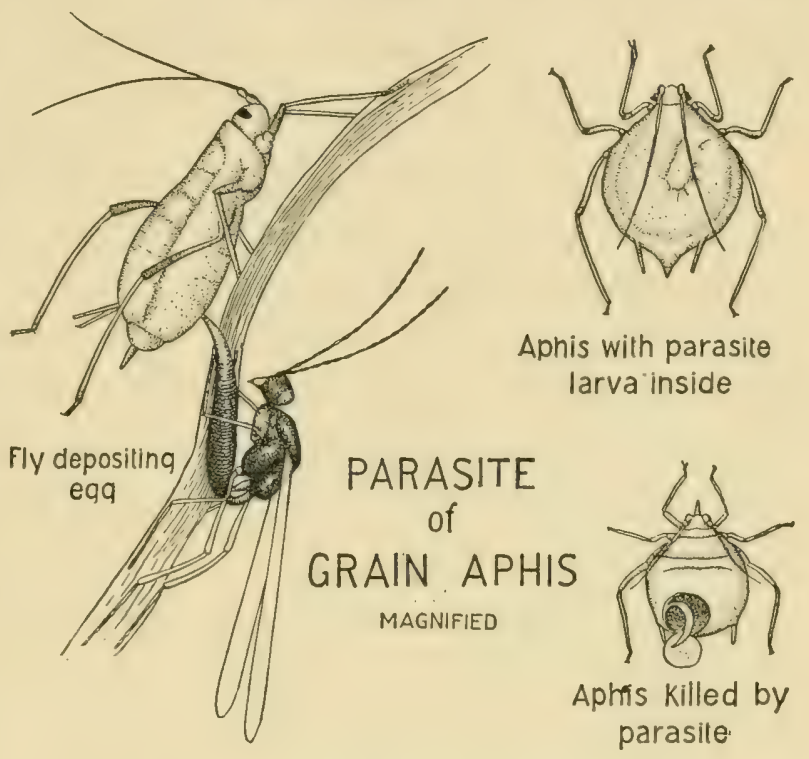
nally the parasite larva becomes fully developed, absorbing practically all the contents of the aphid's body, killing it, and leaving only the inflated skin of the latter to serve as a protection to the parasite. Within this brown inflated skin, the larval parasite changes to a pupa and very soon afterward changes again to a tiny fly, resembling the one that laid the egg. This fly gnaws out a circular piece in the skin of the dead host, making a hole through which it emerges to continue the good work of aphis destruction.

Very often these little parasites are important means of checking outbreaks of destructive aphides. The parasite of the grain aphis, illustrated herewith, is a notable example of this. Under certain conditions which are favorable to the development of the plant louse, but not favorable to the development of the parasite, the former become exceedingly destructive in the grain fields of the South and West. 
Under ordinary conditions, however, this pest seems to be held in check to a great extent by the tiny fly that develops in enormous numbers at its expense.

\section{Primary and Secondary Parasites}

The ichneumon flies discussed in the previous pages develop as parasites of various plant-feeding caterpillars. They are known as primary parasites.

It very commonly happens, however, that these primary parasite larve are themselves attacked by other ichneumon fly larva that attach themselves to the former and suck their lifeblood. Such parasites of parasites are said to be secondary parasites.

It also happens sometimes that one of these secondary parasites is in turn attacked by a third larva that sucks out its lifeblood. Such parasites of parasites of parasites are said to be tertiary parasites.

Perhaps you will be able to remember these facts better if I quote a famous old rhyme :-

The little fleas that do us tease.

Have other fleas that bite 'em, And these in turn have other fleas

And so ad infinitum.

In general these parasites of parasites are spoken of as hyperparasites.

Attention has recently been called by W. F. Fiske to another important phase of parasitism. It very commonly happens that two or even more primary parasites attack the same caterpillar. One of these may devour the available food so rapidly that the other will die. Or they may both become fully developed, but be so dwarfed from the limited food supply that they are unable to lay eggs for an- 
other brood of parasites. Or they both may die from lack of food.

Mr. Fiske has applied the term superparasitism to this excessive parasitism of primary hosts. He classifies the various conditions that may exist as follows:-

I. One parasite lives; the other dies.

(a) The survivor preys upon the other as an accidental secondary parasite. Of common occurrence.

(b) The survivor destroys the other by bringing about the premature death of the host and may or may not devour it incidentally. Of common occurrence.

II. Both parasites live.

(c) Neither is the worse for the circumstances. Very rare.

(d) One or both are so seriously weakened and stunted as to bring about a material reduction in their capacity for reproduction. Common.

III. Neither parasite survives.

(c) This may be brought about through the premature death of the host through excessive parasitism (commonly); or

$(f)$ Through the inability of either parasite to complete its transformations on the limited supply of food. Common.

If you will stop to think what must be constantly happening in the world of insects on account of the existence of these many primary, secondary, and other parasites, you will see that the relations between them must be very complicated. A caterpillar that is a great crop pest becomes abundant. Its primary parasites soon become abundant 
also, because they can multiply rapidly when their caterpillar hosts are numerous. And so they tend to check the caterpillar outbreak. But when the primary parasite is abundant, the secondary parasite can also multiply rapidly. So these will tend to check the numbers of the primary parasite and thus relieve, so to speak, the pressure upon the caterpillars. The case will also be complicated by the many examples of superparasitism. Consequently there is a constant fluctuation in the numbers of these different insects - each one now abundant, then scarce - with a tendency toward a normal level. This complicated condition is often spoken of as the Balance of Nature.

\section{The Chalcid Flies}

The ichneumon flies are not the only important group of four-winged parasites. From an economic point of view the great family of Chalcid Flies is perhaps of as great value, although on account of their smaller size they are not so well known. It is believed, however, by Dr. L. O. Howard, our foremost authority upon these insects, that there are more species in this family than in any other of the great order of four-winged flies.

The Chalcids are very small four-winged flies that develop in the earlier stages of other insects. They are especially likely to infest the eggs and larvæ of butterflies, moths, beetles, and sawflies, as well as the larvæ of great numbers of two and four-winged gallflies, ichneumon flies, wasps, bees, and two-winged flies. They are also very destructive to scale insects and sometimes develop in plant lice and other families of true bugs, as well as in the eggs of tree crickets and other members of the order Orthoptera.

In the case of many Chalcid Flies the life history seems to be as simple as in that of the more familiar ichneumons. 
The mother insect deposits one or more eggs in a caterpillar. The eggs hatch into tiny maggots. The maggots grow inside the body of the host, absorbing its substance. They finally change to pupæ, generally within the body of the dead or dying host, to emerge later as fully developed Chalcid Flies.

Many of the Chalcids are parasites of borers, gallflies, and leaf miners. As a rule, the larvæ in such cases develop as external parasites upon their victims. You may often find examples of these if you will examine a number of leaf-miner cavities. Many other Chalcids are parasites upon the larvæ of the ichneumon flies - that is, they are secondary parasites. In such cases, also, the Chalcid larvæ generally develop as $\mathrm{P}$ ternal feeders upon the ichneumonfly larvæ.

A considerable number of the Chalcid Flies, however, have lives that cannot be told in the few words that will give the life history of the others. They go through so wonderful a course of development that it has required the most careful studies of many scientists for years to trace it out. Even now we know but little, and that only in relation to a very few species. But what we do know enables us to explain certain facts which before were very puzzling.

If you will bring in a lot of nearly full-grown larvæ of the Cabbage Plusia and keep them in a vivarium, a good many of them will be likely to die because they are infested with parasites. If you will isolate those that die, keeping them in small bottles or boxes so you can see how many parasites come from each caterpillar, you will probably find that from some there emerge hundreds if not thousands of tiny four-winged Chalcid Flies. In one case three thousand such flies were counted from one caterpillar. 
If you stop to think, you can scarcely fail to wonder how it was possible for one or even several mother flies to lay so many eggs in a single caterpillar. Indeed, it has been found that one fly probably cannot lay more than one or two hundred eggs, and it would seem hard to believe

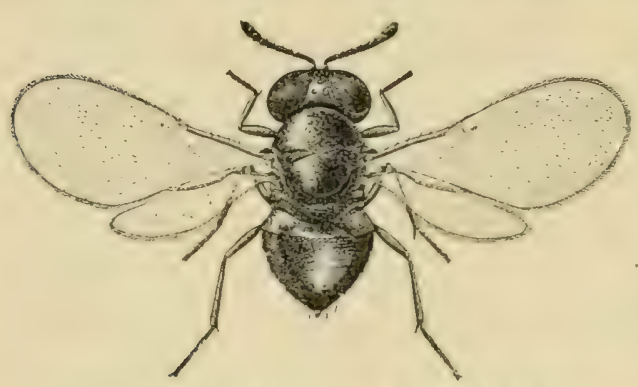

CHALCII) PARASITE OF GrPSY MOTH EGGS Magnified that a dozen or more of these flies laid their eggs upon the Plusia caterpillar all at once. But if they did not do this, how may we account for the three thousand parasites?

The observations of several European entomologists indicate that the life story of these parasites is something like this:-

The Plusia Moth lays its egg upon the cabbage leaf. Shortly afterward the Chalcid Fly lays its egg within the egg of the Plusia Moth.

The Chalcid egg remains within the Plusia egg, so that the latter hatches into a caterpillar with the unhatched Chalcid egg within its body.

After a time the Chalcid egg hatches, but not into a single larva. By a wonderful process its contents develop into hundreds of tiny larva that live on the body substance of the Plusia caterpillar. They grow gradually inside their caterpillar host. The latter finally dies, and the thousands of parasites change to pupæ within the skin. A little later they change to flies.

So, instead of the original egg developing into one Chalcid Fly as is so often the case, it develops into hundreds if not thousands. Suppose a female Chalcid Fly laid an egg in each of a hundred Plusia caterpillars, and each egg 
developed into a thousand flies. Of how many flies would she be the mother?

Do you wonder that these parasites are important enemies of injurious insects, and are often able to check serious outbreaks of great crop pests?

\section{The Proctotrypid Flies}

The third great group of insect parasites is that of the Proctotrypid Flies. These are nearly all very minute creatures somewhat similar to the chalcid flies. A large proportion of them develop in the eggs of other insects, several sometimes emerging from a single host egg. Many of them are parasites upon parasites, and some undergo a development of many larvæ from one egg, as in the case of some of the chalcids.

There is one giant in this family. It is the strange Pelecinus Fly pictured below. Apparently it is a parasite of the white grub - the larva of the common May beetle. The female Pelecinus is much smaller than the male and is a very different-looking insect.

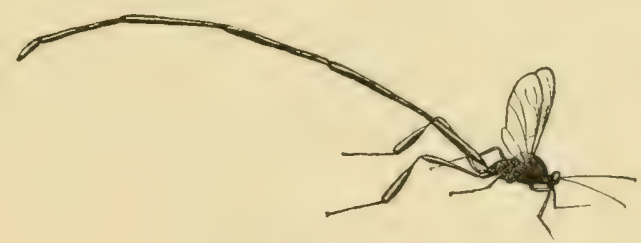

Pelecinus Fly 


\section{OBSERVATIONS FOR PUPILS}

\section{American Tent Caterpillar}

I. Collect a few nearly full-grown caterpillars from the nests late in spring and keep in vivaria, feeding as necessary. See how many of them are killed by parasites.

2. Collect from the nests any cocoons that may be made in them. These are pretty sure to be infested by parasites. See how many sorts of flies come from them.

3. See if you can find in the nests peculiar shrunken caterpillar skins with a cocoon inside. Keep these and rear the parasites.

4. Look up these references:-

Stories of Insect Life, First Series, pages Io-I I. Nature Biographies, pages 22-34.

\section{Cabbage Butterfly}

I. Early in spring look on boards, fences, or the sicles of buildings near gardens where cabbages have been planted, for masses of the small yellow cocoons of microgaster parasites. Keep such cocoons in closed vials or boxes to rear the flies. If two kinds of flies emerge, the larger black ones will be the microgaster flies, which are the primary parasites, and the smaller flies will be secondary parasites.

2. Early in spring collect a number of the cabbage butterfly chrysalids that may be found in boards and fences near old cabbage patches. Keep in small vivaria. From some of them you will be likely to rear hundreds if not thousands of small chalcid flies. Count the number from one chrysalis. Let the flies escape to continue their good work.

3. In autumn collect a number of cabbage worms. They may generally be found abundantly on cabbages. Keep them in vivaria. See how many are killed by parasites.

4. Read The Inseit Book, pages 57-60; Stories of Insect Life, First Series, pages I6-17.

\section{FALL WEB-WORM}

I. Early in autumn collect a score or more nearly full-grown fall web-worms and place in vivaria. Several of them are likely to be killed by parasites.

2. Find cocoons of the fall web-worm in which external parasites are preying on the larvæ.

3. Read The Insect Book, pages 64-68. 


\section{Aphides or Plant Lice}

I. Find some colonies of aphides on some shrub, tree, or herb. They are commonly abundant on cabbage leaves. Look carefully for brown inflated specimens. These are parasitized.

2. Place some of these parasitized aphides in small vials and rear the adult parasitic fly. Notice the hole through which it comes.

3. Read Life Histories of American Insects, pages 197-199.

\section{Sphinx Caterpillars}

I. Look over tomato vines, grapevines, Virginia creeper, and other plants to see if you can find any large sphinx caterpillars bearing on their backs the cocoons of microgaster flies. If you find any, place each in a vivarium.

2. Notice whether the parasitized caterpillar eats and how long it lives. When the flies emerge, notice whether they are all the black microgasters which are the primary parasites or whether there are some bright-colored chalcid flies, which are secondary parasites.

3. Read these references:-

Life Histories of American Insects, pages 18I-I88. Nature Biographies, pages I22-I3I. 


\section{CHAPTER XV}

\section{The Two-winged Parasites}

IN the great order of two-winged flies (Diptera) there are many parasites of other insects. A large proportion of these belong to the family of Tachina Flies (Tachinidre). These are mostly insects of moderate size, similar in appearance to the common house fly but usually somewhat larger.

These Tachina parasites have long been recognized as among the most important enemies of such smooth-skinned

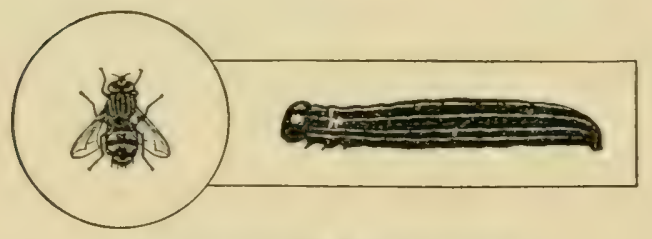

TACHINID of ARMY-WORM caterpillars as cutworms and army worms, often destroying millions of these pests at the time of a single outbreak. The life history as shown by the species that infests the army worm is briefly this: The adult flies deposit their oval whitish eggs upon the outside of the skin of the caterpillar. These eggs shortly hatch into tiny larvæ by burrowing through the eggshell and also through the skin of the caterpillar, finding lodgment among the body tissues. Here they rapidly develop into whitish footless maggots that finally kill the host and emerge to change to the pupa state at or near the surface of the soil. They soon again change to adult flies to continue the generation of the parasite. 


\section{VARIATIONS in Life Histories}

Until recently the life histories of the other Tachina Flies have been supposed to be similar to the development of that preying upon the army worm. But the careful studies of Dr. C. H. T. Townsend upon the parasites of the gypsy and the brown-tail moths show a marvelous variation in the life histories of these flies, and establish their great value as enemies of hairy caterpillars as well as of those with smooth skins. Dr. Townsend found that at least one of the flies that preys upon the brown-tail moth deposits eggs upon the young caterpillars, the eggs hatching and penetrating the skins of the caterpillars, much as in the case of the parasite that kills the army worm. But the other Tachinid parasites had surprisingly different life histories, the discovery of which required months of patient observation.

Several species of these flies deposit their small eggs upon the leaves where the caterpillars are feeding, the eggs being often fastened to the freshly eaten edge of the leaf. The eggs are swallowed by the caterpillar with the leaf particles, generally escaping injury from the jaws because they are so minute. Soon after being swallowed, the eggs hatch into tiny maggots that burrow through the wall of the alimentary canal into the general body cavity of the host. Here they absorb food and grow, finally changing to pupæ and again to adult Tachina Flies - meanwhile causing the death of the caterpillar.

These observations upon the leaf laying of the Tachinid eggs indicated an unsuspected ability on the part of the flies to overcome difficulties. Evidently the hairy clothing of the caterpillars would prove of no value as a protection from parasites if the very food is laden with the eggs of 
the enemy. But the next species to be studied revealed a still different method of reaching the interior of the host.

Observations upon the development of the Tachinid eggs indicated the probability that some kinds of these flies would deposit living larvæ instead of eggs. Two species were especially studied, and it was found that the flies were furnished with "a long curved sheath, into the base of which the ovipositor fits, and which tapers to a microscopically

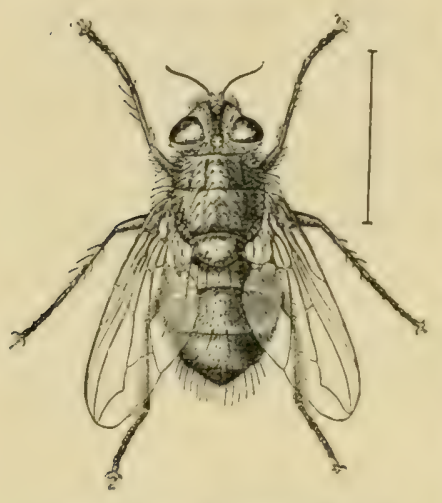

TACHINA PARASITE OF

GYPSY MOTH

Magnified sharp point." By means of this instrument the flies are able to thrust the sheath between the hairs of the caterpillar, cut a hole in the skin, and insert the living larva inside the body of the victim. From the point of view of the parasite this method has obvious advantages: the young larva is placed amid favorable surroundings at once with no danger that it will find itself attached to a molted caterpillar skin.

And the interesting fact was brought out that various native flies have a similar sheath and doubtless a similar life history.

\section{A Remarkable Life History}

It is not strange that Dr. Townsend found a species that we may for convenience call the Large-horned Tachina Fly, the "most remarkable as regards startling deviations from the previously known manner of reproduction" in the group. It was at first supposed that these flies would deposit their eggs upon the skins of caterpillars in the old-fashioned way. To a female fly having this habit, the presence of a good-sized gypsy or brown-tail caterpillar 
should be welcomed as an opportunity for depositing an egg and thus fulfilling the chief purpose of her existence. Consequently the investigators were puzzled to find that these flies not only did not so deposit their eggs, but were actually alarmed by the presence of the caterpillars.

It was easily learned through the study of dead flies that the eggs were large elongated objects, too large to be swallowed safely by the intended victims, - safely, that is, for the parasite. Hence it could not be that they were laid upon the leaves to be eaten. If they were not to be deposited on or in the caterpillars and were not to reach the interior of their hosts by being eaten, how was it to be done?

The final solution may well be given in Dr. Townsend's own words: "After much patient observation and experiment this question was answered. The flies were found to deposit living maggots, not on or in the caterpillars, but, most remarkable to relate, on the green shoots, leaf stems, leaf ribs, and even sometimes on the surface of the leaves." This was not a matter of chance, however, for the flies hovered in the air above the leaves where the caterpillars were at work, evidently seeking for favorable places for depositing the larvæ. By some sense - perhaps sight, perhaps smell, possibly both - they knew when the caterpillars were present and could not be induced to deposit on branches where they were not present or had not been crawling.

In crawling along, many of these caterpillars of the great group of silk spinners have an interesting habit of marking their trail by a silken thread which is continually spun from the silk glands in the mouth as the larva marches to its feeding grounds. This thread serves to guide it back to its permanent or temporary quarters when its meal is fin- 
ished. If you will look at a nest of our native tent caterpillars in spring, you will see silken webs leading from the tents in all directions. These are made by the individual caterpillars on their daily journeys in and out.

It is evident that the Tachina Fly knows about this trail of the silk-spinning caterpillar. And apparently she can tell whether it is a fresh trail on which the caterpillar has gone out and not returned, or an old one which would be comparatively useless for her purpose. " Doubtless," writes Dr. Townsend, "the flies larviposit only on freshly laid strands which have not lost the odor of the caterpillar." Upon this fresh strand of silk she deposits a living larva that is wonderfully adapted to making its way in the world. On the hind end of its body there is a curious sucker-like, membranous, cup-shaped case, by means of which the tiny maggot is fastened to the leaf on or near the silken thread. On the front end of its body is a slightly sickle-shaped hook, admirably designed for rending the skin of the caterpillar. Thus it is anchored in the path of its prospective victim with its stiletto ready for business at a moment's notice. As long as all is quiet, it lies lazily down, but on any disturbance, such as would be made by the homeward return of the caterpillar, our young pirate becomes active and ready to fasten upon the expected caterpillar.

If you will examine a good-sized web-worm or gypsy moth caterpillar you will find that it is well protected by its hairy covering along its back and sides. But on the lower surface, the skin is more exposed, and it is obvious that this Tachinid larva lying in wait with its stiletto will find the caterpillar as it crawls above it an easy victim for its hook. When the mouth hook is thrust through the skin, the pull of the caterpillar loosens the hold of the parasite upon the membranous case at the hind end of its body and the par- 
asite remains with its host, working its way through the skin to the inside and there remaining until it reaches its full development into the adult fly, at the expense of the life of its caterpillar victim.

\section{OBSERVATIONS FOR PUPILS}

I. Examine carefully the caterpillars you find to see if any of them show Tachinid eggs.

2. Watch for the development of Tachina Flies from the caterpillars you rear in breeding cages.

Read:-

The Value of Insect Parasitism to the American Farmer, Yearbook Reprint 447. The Relations between Birds and Insects, Yearbook Reprint 486. 


\section{CHAPTER XVI}

\section{The Pollination and Fertilization of Flowers}

ONE of the most striking features of the early spring landscape in a fruit-growing region is that of the great white masses of cherry blossoms. These are to be seen at long distances wherever a cultivated cherry tree is growing. If you will pick one of these blossoms and look at it care-

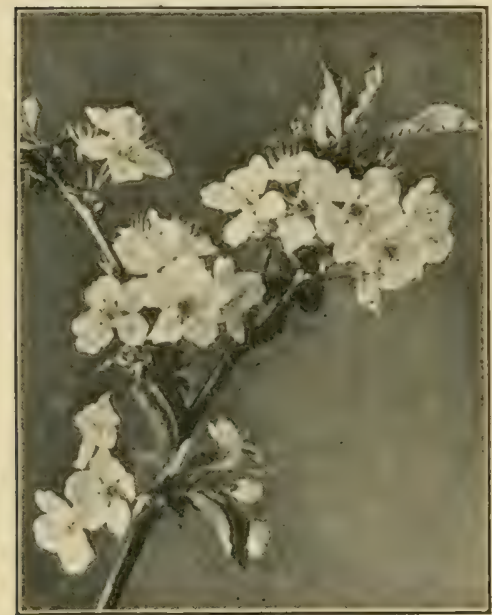

CherRY BLOSSOMS fully for a moment, you will be able to see readily the various parts of which each flower consists.

Hold the stem in one hand and you will see a little green cup at its upper end; this cup is called the receptacle. Around the outer edges of the cup are five small lobes; these are called the sepals. They are greenish and served to protect the flower when it was a bud. In front of the sepals and between them are the five large white potals, which make the flower conspicuous. Inside the petals are many small pollen-bearing organs called stamcns; each stamen consists of a sort of stalk or flament and a pollen bag or anther. Very likely the anther in the specimen in hand will have broken open so that the powdery pollen is plainly visible. In the center of the flower is a single slender vertical object called the pistil. 
It will be worth while to cut away carefully the stamens, petals, sepals, and a portion of the receptacle on one side in order to get a complete view of the pistil. You will then readily see, especially through a hand lens, that this pistil consists of an enlarged part at the bottom called the ovary, above which is a slender stalk called the stylc, on the upper end of which is an enlarged portion called the stigma. If now you cut away carefully a piece of one side

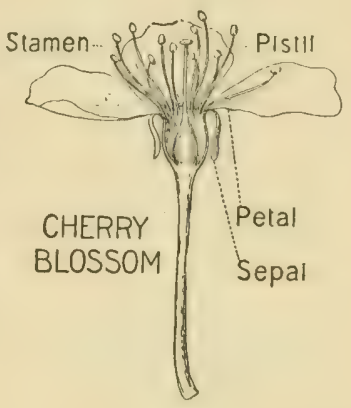
of the ovary, you will see within a single little egg-shaped object called the ovule.

If you look carefully with a lens at the glistening surface of the receptacle, you will probably see certain drops of liquid; these are drops of ncctar which the bees gather when they visit the blossoms and carry home to make into honey.

A week or so after the cherry trees have begun to blossom, the landscape is lighted up by the beautiful flowers of the apple trees. These may be seen at great distances, and by their color and odor serve to attract the notice of thousands of insects, which may be seen and

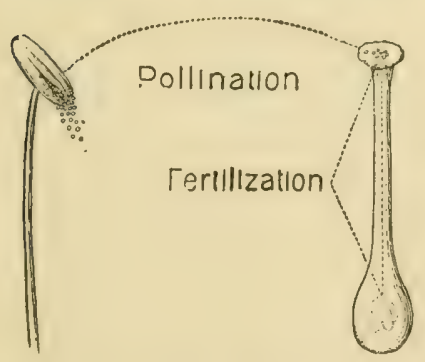
heard flying among the blossoms, busily gathering both nectar and pollen.

If you examine an apple blossom carefully, you will see that in many respects it resembles the flower of the cherry, but differs in having five styles and stigmas which at their base are united to form a compound ovary. In this ovary are five little cells in which the ovules are held. There is thus one of these 
cells for each style and stigma. You should see the interesting nectar cup on the top of the ovary, on which glistening drops of nectar may generally be found.

\section{Squash Blossoms}

People are sometimes puzzled over the fact that cucumbers and squashes seem to have so many blossoms in pro-

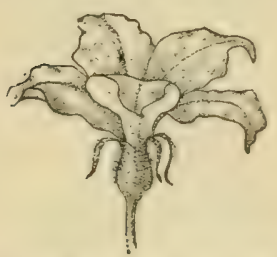

CUCUMiBer: POLLENBEARING FLOWER

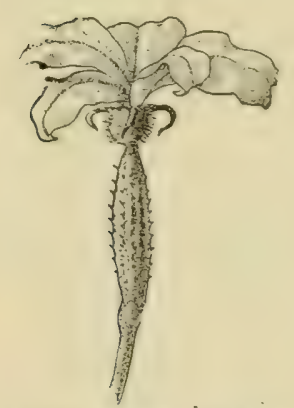

Cucumber : SeEdBEARING FLOWER portion to the number of fruits produced. If you examine, however, the flowers upon one of these plants, you will soon be able to tell the reason for this. You will find that most of the flowers consist only of sepals, petals, and stamens, and that such flowers are easily recognized from a side view, by the fact that there is below the blossom no little cucumber or squash to develop later into a fruit. These flowers are stamen-bearing or staminate blossoms, and in general they are smaller than the other kind of flowers found upon the same plants, which consist of sepals, petals, and a single pistil. The ovary of the pistil which you will recognize at once as a miniature cucumber or squash is below the main blossom, but has a style that runs up through the center of the flower and bears upon its tip a well-developed stigma. These are the seed-bearing or pistillate flowers.

If you should cut open the ovary of one of these pistillate flowers, you would find inside a large number of tiny seedlike bodies called the ovules. In order that these ovules may develop into seeds, it is necessary that some pollen from the staminate blossoms should be placed upon the 
stigmas of the pistillate blossoms and should send down through the style certain pollen tubes which come in contact with these tiny ovules and fortilise them. When they are inus fertilized, the ovules will begin to develop into seeds. The fact that these ovules are developing into seeds will cause the surrounding ovary, which is the outer part of the little cucumber or squash, also to develop, and the whole will finally mature into a squash or cucumber with the seeds inside.

If you look at these flowers again, you will see that the pollen is sticky and well protected within the lobes of the yellow corolla. You will also see that the stigma is likewise somewhat sheltered by the lobes of its corolla, and it will easily be evident that there is no likelihood that the pollen will either fall or be blown by the wind from one flower to the other. How, then, is it carried? This is a question you can easily answer by a few moments' observation on a bright summer day. You will see great numbers of bees of many sizes and kinds visiting all these flowers. If you watch these bees, you will see that their bodies are more or less dusted with pollen and that when they enter the pistillate blossoms, some of this pollen is rubbed off upon the stigmas. Consequently you will know, that while the bees are gathering pollen and nectar to store up in their hives or nests, they are also helping the plants by carrying the pollen from one flower to another. This carrying of the pollen from stamen to stigma is called pollination, and the bees which thus bring about this pollination are called pollenizers or pollinators.

If you examine many strawberry blossoms, looking especially to see whether they all have about the same number of pistils and stamens, you will probably find that upon some plants the flowers possess both sets of these 
organs, while upon other plants you will find that the blossoms have an abundance of pistils, but very few stamens. If you think of this condition for a moment, you will easily see that in the case of the latter, pollen must be brought from those flowers having many stamens, if the

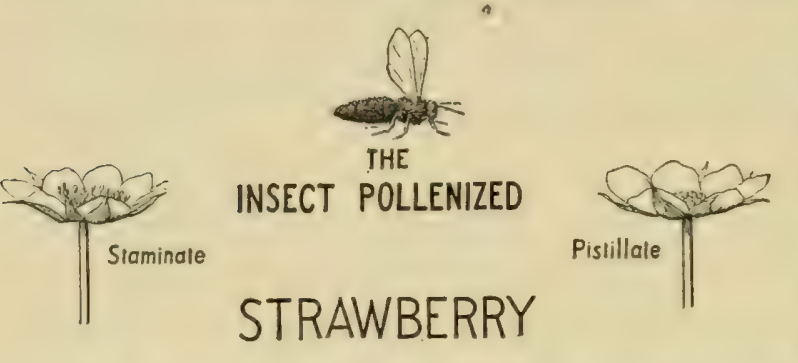
little ovules are to be fertilized and the seeds to develop.

If you watch a strawberry bed for a few moments some bright day in May, you will have no trouble seeing how this pollen is transferred from one blossom to the other, for you are very likely to find a great many insects attracted by the white petals of the strawberry blossoms, gathering, perhaps nectar, perhaps pollen, perhaps both. Most of these insects will be small bees, possibly the common honeybees, in case there are hives of these near at hand. Should you follow a single bee as she goes from flower to flower, you would probably find that she often passes from a pollenbearing blossom to a pistil-bearing blossom,

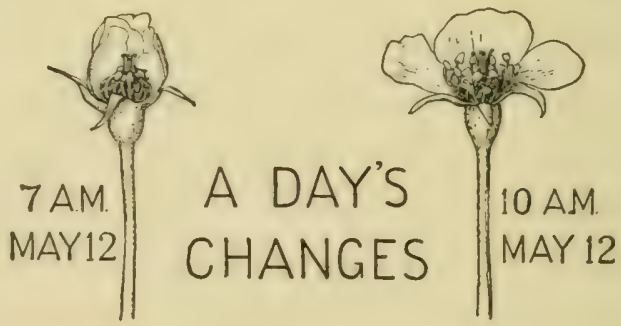

IN A

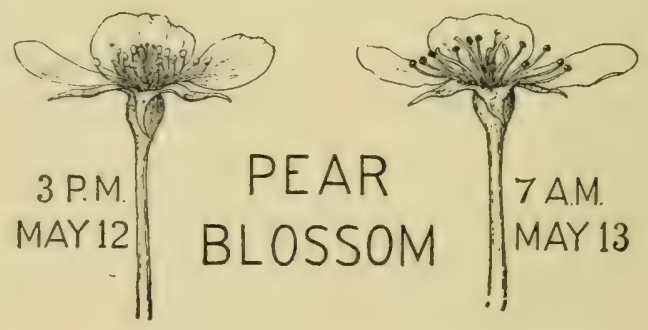
and after she has thus visited such a flower, if you would look through a lens at the stigmas, you would 
doubtless see that a good deal of the pollen had been left upon these.

You certainly should be now in a position to understand what is constantly happening in all strawberry beds. The bees are busily at work carrying pollen from blossom to blossom, and thus causing the fertilization of the little ovules and their development into seed. This growth of the seed upon the surface of the future berry causes the parts beneath the seeds also to develop into the luscious fruit.

You can easily prove that this development of the berry will not take place unless the seeds are fertilized by the pollen. For if you cut off the upper part of the pistils upon one side of the berry as the petals are unfolding, so as to remove the stigmas, and then watch what happens, you will be likely to find that one side of the berry which is left to be fertilized by the bees will develop and that the other side will not develop. You will thus have been the cause of forming an abnormal berry of very little value, but I hope you will have proved to yourself that the bees, which are thus making possible our crops of strawberries, are farm friends, without which we should fare badly.

\section{Cross-Fertilized Flowers}

It is evident that in the case of the squashes and cucumbers, as well as of the strawberries, the pollen that occurs upon the stigmas of a seed-bearing flower must come from another flower. When pollen is thus carried from one flower to another, the blossom is said to be crosspollcnized and the ovules as a result are cross-fortilized; that is, the ovules are fertilized by pollen from another blossom which is usually upon another plant. When a flower is pollenized and fertilized by the pollen from its 
own anthers, it is said to be self-pollenised and the ovules are said to be self-fertilized.

As a matter of fact, the great majority of flowering plants are cross-fertilized. Many of them have special devices for preventing self-pollination. These devices include the separation of the stamens and pistils in different flowers, as in the case of the squashes and cucumbers, the maturing of the stamens and pistils at different times, or a difference in length of stamens and pistils which prevents the pollen from getting upon the stigmas. One of the commonest methods that nature employs in preventing self-fertilization is in rendering the pollen incapable of fertilizing the ovules of the flower in which it developed. Such flowers are said to be silf-stcrilc, and very commonly none of the pollen upon a plant is able to fertilize the ovules of any of the flowers upon that plant. Not only this, but in many cases the pollen of a certain variety of apple, pear, or plum is incapable of fertilizing any other flowers of the same variety, even upon different trees. In such cases the whole variety is said to be self-sterile and must be pollenized by flowers of some other variety.

The discovery that a large proportion of the varieties of tree fruits are self-sterile is one of the most important recent developments in our knowledge of fruit growing. It has been observed for a long time that the variety of plums called the Wild Goose, when planted alone, will not set fruit, even though there be many trees near together. It had also been noticed that when other varieties of plums were planted near the Wild Goose trees, the latter commonly produced abundant crops. An investigation of the cause of this, undertaken by M. B. Waite, of the United States Department of Agriculture, showed that this lack on the part of the Wild Goose trees was due chiefly to the fact 
that the variety is self-sterile, and requires for the development of fruit the transfer of pollen from some other sort of plum.

Other investigators have also made further studies of the subject, the more important of these having been made by Bailey, Fletcher, Kerr, and Waugh, with results which are of great importance to every fruit grower.

It has been pretty conclusively shown that in the case of a large proportion of orchard fruits, a much more abundant crop is produced where cross pollination with another variety takes place. It has also been shown that in many cases there is a decided increase in the size of such fruits. This increase is so marked that it is well worth while for any fruit grower to take it into consideration in planning his orchard. The increase in size is believed by Fletcher to be due to the fact that "the foreign pollen generally stimulates the fruit to a better growth, because it is more acceptable to the pistils, not because it carries over the size-character of the variety from which it came."

In selecting varieties of fruit trees with reference to cross-fertilization it is important to choose those which blossom at the same time.

\section{Agencies that Carky Pollen}

There are three principal agencies concerned in bringing about the cross-pollination of plants. These are :-

I. The wind which carries the pollen for a large proportion of the forest trees that blossom early in spring, but which apparently has comparatively little to do with the cross-pollination of the flowers of most fruit trees and cultivated plants. Such plants are said to be ancmophilons or wind-loving plants. 
2. Certain birds, especially humming birds, which carry pollen from flower to flower for a comparatively few species in temperate regions, although apparently in tropical regions there are many species so pollenized. Such plants are said to be omimophilons or bird-loving plants.

3. Insects of many kinds, especially bees, wasps, butterflies, and flies, which carry the pollen for the great majority of flowering plants and in so doing confer an inestimable benefit upon mankind. Such plants are said to be entomophilous or insect-loving plants.

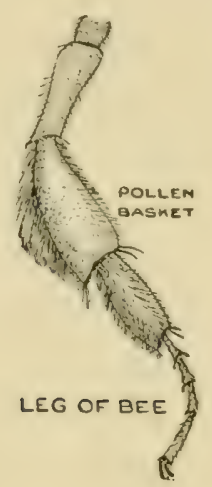




\section{CHAPTER XVII}

\section{The Insect Pollinators}

By far the most important insect pollinators of cultivated crops are the bees of the order Hymenoptera. The bees form a superfamily called Apina, the members of which as a rule are known by the fact that under a lens the hairs which cover their bodies are seen to be provided with many minute barbs. In most cases, also, the first joint of the hind tarsi is expanded and hairy, being adapted to carrying pollen. The tarsi are the short joints at the ends of the legs, and the first is next to the second large joint of the legs, which in a great many bees is especially developed into a so-called pollen basket. This may readily be seen by examining the hind legs of a bumblebee or other large bee. The barbed hairs over the body are obviously an adaptation for carrying pollen, and they enable these insects to become the most efficient of all pollen carriers.

The bees, as a whole, are divided into two great groups or families - the short-tongued bees (Andrenidæ) and the long-tongued bees (Apidæ).

The short-tongued bees collect nectar and pollen from a great variety of flowers, but they are not able to insert their tongues into the long tubes of flowers in which the nectar is deeply concealed. These bees, for the most part, build their nests in the ground, burrowing holes into which they carry a mixture of nectar and pollen upon which the larval bees develop. Most of these short-tongued bees are very small, and many of them may readily be found by a few 
minutes' inspection of flowers in which the nectar is easily accessible.

The long-tongued bees may for our present purpose be arranged into two principal groups, those that live solitary lives and those that live social lives. The former are comparatively few and so are of little importance as pollinators of cultivated crops. One of the most distinctive forms is that of the Leaf Cutter Bees, which have the curious habit of cutting out pieces of leaves, to use in building their nests. Roses and other plants often show leaflets in which a rounded piece has been neatly cut out. This is generally the work of one of these Leaf Cutter Bees. These insects may be recognized from the fact that the under side of the body is covered with a brush of hairs, which is used in collecting the pollen for provisioning the nests.

\section{SOCIAL BEES}

But the insects to which mankind is indebted beyond all others for carrying pollen are the social bees, of which the familiar Bumblebee and the domestic Honeybee are typical examples. These bees live in colonies, a single colony often consisting of a vast number of individuals. To a large extent these insects have at least three distinct forms in each colony. In addition to the true males and females or the drones and queens, there are great numbers of workers, which are generally smaller in size and which do most of the work of gathering nectar and pollen to provision the nests with honey and bee bread.

The yearly cycle in the life of the Bumblebees furnishes a good illustration of the habits of the social bees. Early in spring you may often find the large queen Bumblebees -flying slowly about close to the surface of the ground in a 
more or less zigzag fashion. They often alight and explore some nook or cranny that seems to promise a favorable situation for a nest. These queen Bumblebees are the only kind that have been able to live through the winter, and they have been sheltered in some deserted mouse nest or similar covering.

When the queen Bumblebee finds a place that she thinks suitable for a new nest, she adopts it for the home of her future colony. Then she flies to the carly spring flowers and gathers nectar and pollen which she brings to her nest and of which she forms little balls of "bee bread." This consists simply of a sort of paste made by mixing honey and pollen together. Upon each of these food balls, the queen bee deposits an egg.

Very shortly each of these eggs hatches into a tiny footless larva that feeds upon the bee bread and gradu-

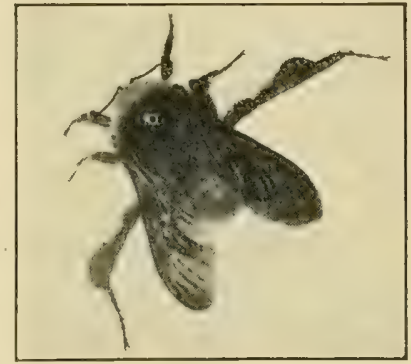

BUMBLEBEE SHOWING POLLEN MASSES ON HIND LEGS ally increases in size. Before very long it becomes full-grown as a larva and changes to a pupa or chrysalis, and a little later into an adult Bumblebee. These adults are smaller than the queens and are the first of the season's broods of worker Bumblebees.

These worker bees soon undertake a large part of the care of the colony. They form the curious and characteristic cells which are found so abundantly in Bumblebees' nests late in summer, and they gather nectar and pollen for the food of the young. The queen bee is thus left free to deposit eggs for more broods of future workers.

Thus the colony passes through the summer, constantly increasing in numbers and all working together for the good of the great bee family. They visit flowers of many 
different sorts, especially those in which the nectar is deeply secreted, as they are able to reach such nectar by means of their very long tongues. They go about from day to day, performing for mankind a service of inestimable value and deserving his support and protection.

Toward the end of summer a brood of males and females, or drones and queens, is developed. These come forth late in summer or early in autumn, visiting flowers freely along with the workers. All, however, except the queens, perish when cold weather comes, and only such queens as find adequate shelter are able to live through the winter to begin again the cycle of the colony.

\section{Honeybees and Related Insects}

There are many kinds of wild bees, besides the bumblebees, which are useful in the pollination of crops. In many thickly settled communities, however, these are not so important as are the familiar hive bees, which, from the point of view of usefulness to man, have the great advantage that they can be introduced into cleanly cultivated regions where there are comparatively few places for wild bees to breed. In many greenhouses, hives of bees are regularly kept to bring about the pollination of cucumber crops, a process that formerly required much hand work on the part of men. Outdoors in large orchards, such hives seem almost as essential for insuring the cross-pollination of the millions of flowers to be found upon the hundreds or thousands of apple trees. These bees, of course, have the additional advantage that they furnish honey to the owner.

There are many other members of the order Hymenoptera, which may commonly be found upon the flowers of plants, seeking nectar or pollen, or both. The wasps, hornets, yellow jackets, sawflies, and ichneumon flies may 
all be found at times upon flowers, either wild or cultivated. So far as cultivated crops are concerned, however, these insects are much less important than are the bees, both on account of their smaller numbers and the lack of barbed hairs upon their bodies for catching and carrying the pollen.

\section{Two-winged Flies}

In the great order of two-winged flies (Diptera) there are hundreds of species that freely visit flowers. Some come for nectar, some for pollen, some for both. The legs and bodies of many of these flies are furnished with hairs, to which the pollen becomes attached and by means of which it is carried from the anthers of one blossom to the stigmas of another. These flies, as a rule, however, visit those flowers in which the nectar is more or less exposed in shallow cups, and, except perhaps in the case of certain fruit crops, they are not nearly so important as pollinators as are the social bees.

\section{Butterflies ANd Moths}

In the great order of scale-winged insects, the moths and butterflies (Lepidoptera), the great majority of species are especially adapted to living as adults upon the nectar of flowers. Consequently, there are many plants the blossoms of which are especially adapted to cross-pollination by means of butterflies or moths. These insects have long sucking tubes, each of which is commonly coiled like a watch spring on the under side of the insect's head. When the butterfly or moth visits a flower, however, it uncoils the tongue and projects it forward to reach the nectar of the blossom. Often these tongues are of extraordinary length, and so it is not surprising to find that the flowers 
especially adapted to the visits of moths and butterflies commonly have their nectar deeply concealed where it cannot be reached by most other insects.

The great group of hawk moths or sphinx moths is one of the most interesting from the point of view of pollination. By examining a beautiful Easter lily, one can readily see the relation between these moths and the pollination of such flowers.

"If you remove one side of the white flower cup, you will see that the pistil consists of a long style running the whole length of the flower, with the sticky stigmas at the end. Grouped on the sides are the stamens, which also have long filaments tipped with the anthers at the mouth of the flower. Evidently no other insects can get the nectar at the base of the cup; the sphinx moths are the only ones adapted to derive benefit from such a blossom. But for them the adaptation is perfect. The tongues of the larger species will reach the honey, while their heads come in contact with the anthers or stigmas and perform the pollenizing office.

"These moths are not day-fliers: they appear at dusk, and during the early evening they shoot like meteors from blossom to blossom, hovering hawklike in the mouth of the flower, while the long tongue is inserted to extract the hidden nectar. The immaculate whiteness of the lilies renders them conspicuous in the twilight: they then shed their perfume most abundantly, and, in some species at least, produce the most nectar. These methods the lily has developed to attract her pollen-carrying guests. The latter also are assisted in the adaptation; their long tongues, the shape of their heads, their large eyes, all are useful to the lily, while the swiftness of their flight and the businesslike way in which they utilize the few hours during which 
they are abroad enable them to pollenize a large number of blossoms in a short time." 1

Some of the other lilies show similar adaptations to the visits of sphinx moths, and many of the honeysuckles and other flowering plants are adapted to pollination by such visitors.

1 Weed, Ten Nerw England Blossoms.

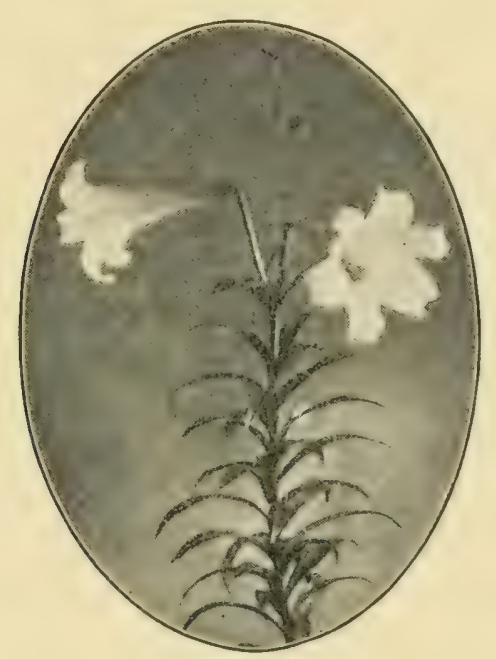

EASTER LILY 


\section{OBSERVATIONS FOR PUPILS}

\section{The APPle \\ A}

I. Make a careful study of some apple blossoms. See if you can identify all of these parts :-

The calyx lobes, which represent the sepals.

The petals.

The stamens, each with filament and anther, the Jatter containing pollen.

The pistils, united in the ovary, with the lower part of the styles also united and bearing a fringe of hairs, then separating and each having the stigma at the top.

The nectar cup on the top of the ovary.

2. See if you can determine how the nectar is protected from ants and wingless insects by the palisade of filaments around the outside and the hairs upon the united styles in the middle.

Thrust a shirp pencil point down through the hairs to see how the long-tongued bee could get at the nectar while the short-tongued ant is excluded from it.

3. Watch the apple trees on a bright day to see what sorts of insects you find visiting the blossoms.

Make a list of as many different kinds as you recognize. Are any of the bees collecting honey? Can you see them thrust their tongues down to get the nectar?

4. When it rains much of the time during the blossoming of the apple trees, are the bees able to carry the pollen as well as when the weather is fair?

\section{$B$}

I. Tell or write a little story with this title: The Mission of the Apple Petals. Follow some such outline as this :-

The pistil in the bud.

The nectar cup that it covers.

The purpose in attracting the bees.

The carrying of the pollen by the bees.

The fertilization of the flowers.

The falling away of the petals.

The development of the fruit. 
2. If your story is written, illustrate it by such drawings of petals and flowers as seem to you desirable.

\section{Read : -}

The Pollination of Pomaceous Fruits, Yearbook Reprint 157.

\section{The Cherix and The Plum}

Make a study of the structure of the blossom and its relation to insect visitors in the case of the cherry or the plum. Follow in a general way the outline given above for the apple.

\section{The Strawberry}

\section{$A$}

I. Examine a number of strawberry blossoms and see if you can find some in which there are many pistils and but ferv stamens, and others in which there are both pistils and stamens in abundance.

2. Watch the flowers on a bright day to see what insects are visiting them. Can you tell whether the insects are gathering nectar or pollen or both. Do you see any pollen on the bodies or legs of the bees ?

3. Watch a bee carefully as it goes from one flower to another. WVould it be likely that some pollen would be brushed upon the stigmas as the bee gathers nectar?

4. How does the length of the blossoming period of the strawberry compare with that of the apple? Are there more clays for the bees to cross-pollenize the strawberry than the apple?

5. Tie a bit of mosquito netting or cheesecloth over one of the pistillate strawberry blossoms before it opens so as to exclude any insect visitor. See if a well-developed strawberry is formed after the petals fall off.

\section{$B$}

I. Tell or write a little story with some such title as this: The Strawberry and the Bees. Show how much we owe to the bees for carrying the pollen from flower to flower.

2. Illustrate your story with drawings of hees and strawberry blossoms.

\section{Cucumbers and Squashes \\ $A$}

I. Examine carefully all the flowers upon a single long stem of a cucumber, squash, pumpkin, or melon plant. How many of the 
blossoms are pollen-bearing or staminate, and how many are seedbearing ? You may know the latter by the little fruit below the flower.

2. On a bright day see what kinds of insects are visiting the Howers. Are they mostly bees? Do you find any bumblebees? Watch one of the bees as it comes out of a pollen-bearing blossom and see if you can see any pollen upon its body.

3. Watch one of the bees as it leaves a pollen-bearing blossom. Do you find that it ever goes to a seed-bearing blossom ? See if any of the pollen is rubbed from the body of the bee upon the stigma of the flower.

4. See if any bees are at work on damp days when there is a little mist or rain in the air. If any bees are at work, what kinds are they?

\section{B}

I. Write or tell a little story with this title: The Pollination of the Squash Blossom. If it is a cucumber you observed, make it: The Pollination of the Cucumber Blossom.

Follow this outline:-

The pollen-bearing flower.

The seed-bearing flower.

The need of the transfer of pollen.

The nectar that attracts the bees.

The color that advertises the nectar.

The bees that carry the pollen.

The wilting of the pollen-bearing blossoms.

The growth of the fruit.

2. Make a drawing of the side view of each kind of flower, and, if you have time, a longitudinal sectional view of the seed-bearing ovary. 


\section{PART III}

FRIENDS AND FOES AMONG THE FUNGI 

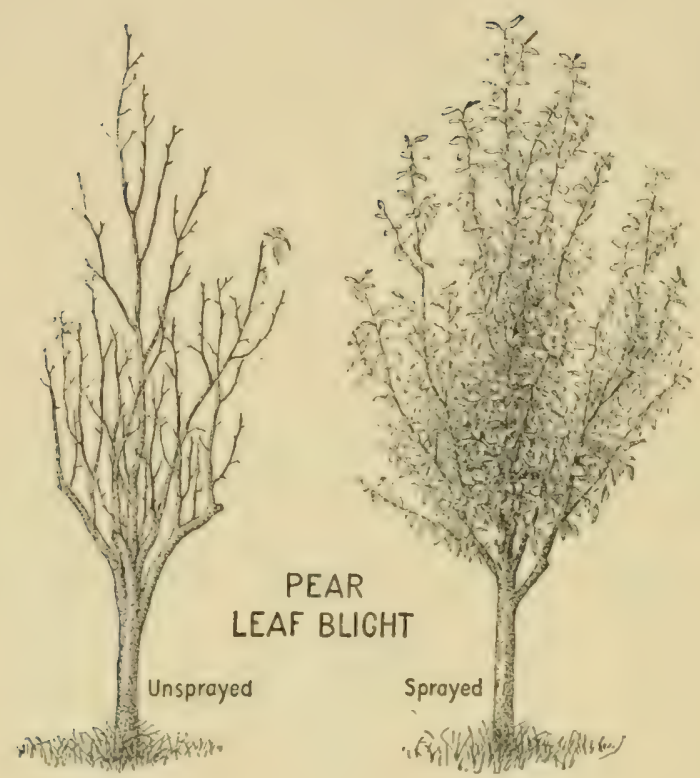

\section{The Bouklet on FungI}

In addition to the drawings and written pages suggested under Observations for Pupils it is easy to enrich the booklet on fungi by mounted specimens of leaves and other parts of plants affected by various fungous parasites. These occur everywhere in autumn, so they are very readily obtained. They may be pressed for a few days between papers, changing daily, and then mounted by strips of gummed labels. The name, locality, date, and collector should be printed on each sheet. 


\section{CHAPTER XVIII}

\section{Mushrooms, Toadstools, and Molds}

Every one is familiar with the peculiar umbrella-like plants called toadstools and mushrooms, which may be found abundantly during damp weather, especially in early autumn, in fields and woods. They differ from our common plants in that they have none of the green coloring matter called chlorophyl by means of which the higher plants carry on the processes of their life.

These toadstools and mushrooms belong to the great group of fungi - a group which includes a large number of species of plants. The fungi rank lower in the scale of life than the trees and herbs which we commonly

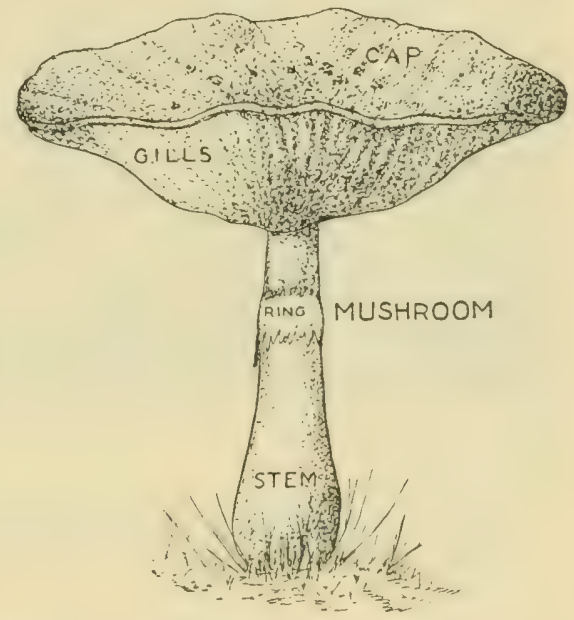
have in mind when we speak of plants, but they serve many important purposes in the economy of nature.

If you will place a well-developed toadstool of the general type of the specimen shown in the picture above in the position in which it grew, upon a piece of white paper, and leave it for a day or two, the paper will probably be covered with a fine dark powder. A similar powder will be found upon the thin plates hanging down from the upper part of the toadstool. If some of this powder be placed under 
a high power of the microscope, it will be seen to consist of great numbers of very small, roundish particles. These are the spores or reproductive bodies of the mushroom, and they may be likened in their relation to the life of the fungus to the seeds of the higher plants.

When these spores are produced by the toadstool outdoors, millions of them are blown away by the wind, or washed away by the rain. When one of them chances to

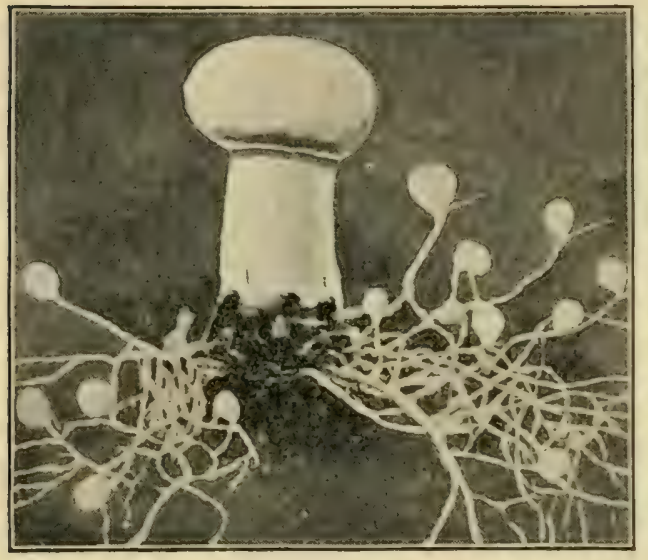

MUSHROOM

Soil washed from "spawn" and "buttons," showing the minute young "buttons" attached to the strands of mycelium fall upon rich earth, it sends out a little tube, in much the same way that a sprouting seed sends out its germinating radicle. After this tube has grown between the soil particles a little way, it develops branches that push about between the decaying bits of organic matter and absorb materials of growth from them. Because of this the toadstool is called a sapropliyte - a plant living upon decaying organic matter. These branches in turn send out other branches and thus form the spawn, or vegetative portion of the fungus. This is also often called the mycelium.

This spawn continues to develop beneath the surface of the soil for a while, until at certain places there are special growths from each of which one or more toadstools are produced, often appearing suddenly above the surface.

Each toadstool consists of a stem, above which is a wide top suggestive of an umbrella. This top bears on 
the under side curious thin vertical plates, called gills or lamella. On these plates the spores develop, falling from them to the ground or being blown away by the winds. The plant has now fulfilled the purpose of its existence, and it rapidly decays - a process much hastened by the numerous insect larvæ that feed upon the inner tissues of the fungus.

On most toadstools and mushrooms there may be found a ring of thin tissue with ragged edges, hanging from the upper part of the stem. This is the remnant of a delicate membrane, called the vclum, or veil, which covered the surface of the cap during its rapid growth.

Those species of these fleshy fungi which are not poisonous and are good to eat are called mushrooms, while the poisonous ones are commonly called toadstools. No general rule can be given for distinguishing the edible from the poisonous kinds.

Perhaps a clearer idea of the relation between the mycelium of a fungus and its reproductive spores may be obtained from the picture above of one of the common molds that grow upon

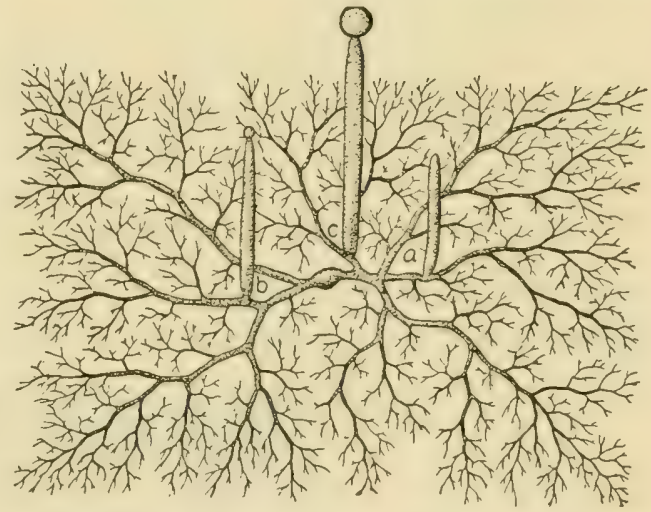

Mycelium of the Common Mold

From the spore lying near the middle of the figure, and strongly swollen, one sees the thick threads of the mycelium arise. From the level of the mycelium arise three vertical, fertile stalks, $a, b, c$, of which $a$ is still very young and that at $b$ is already producing a case containing many spores. All highly magnified. bread or other materials in dark, moist situations. The branching threads of the mycelium are spread out over a wide space. At certain points rise vertical columns. On 
the top of these the spores are produced. Compare it with an apple tree: the mycelium corresponds in a way to the roots; the vertical column to the trunk; the spores to the seeds in the fruit.

Can you not see that this mold is really a plant, though it lacks the green coloring matter of our more familiar plants?

\section{PARASITIC FungI}

The toadstools, mushrooms, and molds are all fungi that live at the expense of dead or decaying plant or animal materials. They are not of very great interest to agriculture. I have described them here to lead to a clearer knowledge of certain other fungi that are of exceeding importance to growing crops. These are the fungi that develop at the expense of the tissues of living plants; that is, they are parasites rather than saprophytes. They bring disease and death to many crops and cause the myriad forms of fungous diseases that destroy millions of dollars worth of farm and garden produce every year.

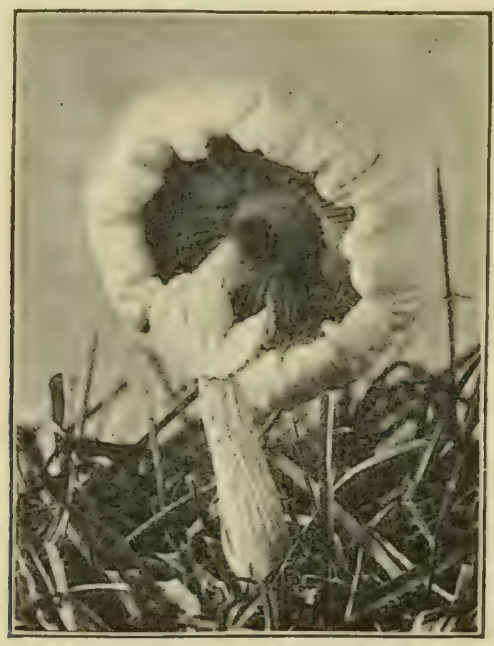

A Dying MUSHROOM 


\section{CHAPTER XIX}

\section{The Downy Mildews}

THE group of fungi commonly called the Downy Mildews includes several of the most destructive fungous enemies of cultivated crops. These parasites grow at the expense of the vital tissues of the host plants, penetrating between the cells in all directions and sending into the cells curious projections that absorb their contents. They produce summer spores in untold billions, to be widely scattered so quickly that whole fields may seem to succumb in a single day. The technical name of the great group to which they belong is Phycomycetes.

\section{Potato IBLight}

In America the Downy Milclew of the Potato probably causes the greatest loss of any of these parasites, especially in the Eastern states. During recent years this disease has been generally called the Late Blight to distinguish it from the Early Blight of Potatoes due to a different fungus. This Late Blight causes not only the death of leaves and stems, but also the decay of the tubers. It destroys millions of dollars worth of potatoes.

To get an idea of what happens in a potato field when it seems suddenly to blight, let us assume that we have before us a green and healthy plant in August. Its leaves are busily engaged absorbing the sunshine and converting the unorganized substances from the soil, moisture, and air into highly organized materials. These it is sending down 
through its lusty stalks to the little tubers at the ends of the underground stems, there to be stored in cells as starch. All over the surfaces of the leaves are the tiny openings or breathing pores through which the air gets to the leaf cells and through which the surplus water may es-

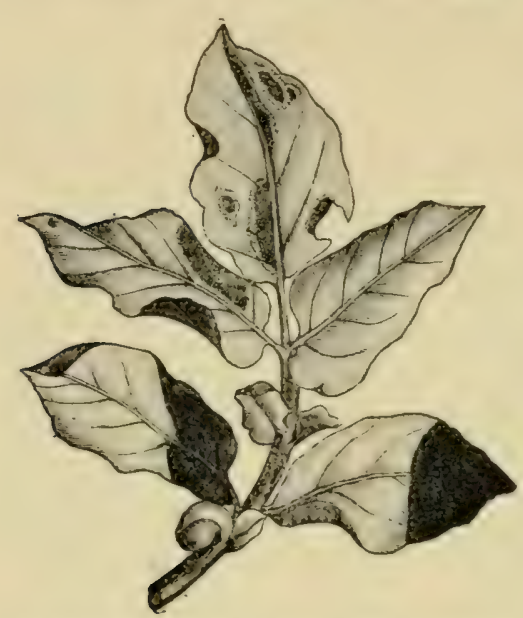

POTATO LEAF AFFECTED WITH LATE BLIGHT

cape as vapor. The plant is healthy and vigorous and apparently enjoying its existence.

But one day a breeze springs up that carries particles of dust from field to field. In the dust are many summer spores of the mildew fungus, some of which are caught on the surface of the potato leaves. The breeze is followed by a summer shower that soon passes, leaving the foliage wet with glistening drops that reflect the hues of the rainbow as the sun comes out again.

In one of these drops a Downy Mildew spore is held. It needed only the moisture to cause it to produce curious stuam spores that swim about in the water and finally germinate, each by sending out a slender tube. The tube lengthens, the end creeping along till it reaches one of the open breathing pores. It enters this and then begins to grow rapidly, sending branching threads between the leaf cells in all directions. These threads form the mycelium of the fungus. They send into the cells short suckerlike branches through which the contents of the cells are absorbed. Thus the threads of the fungus penetrate through all the tissues of the leaf. Finally they run through the petiole to the main stalk and perhaps down 
the stalk to the forming tuber below. Wherever they go, they cause the death of the cells of living tissue, breaking them up, turning them brown, and causing a foul odor to be given off. In the case of the stalks and tubers the result appears as a sort of rot.

The prosperous, healthy plant is thus stricken with a sudden sickness that may well be called a blight. The tubers are no longer able to increase in size through the addition of starch cells. A field thus blighted is a sight that may well bring dismay to the owner who had hoped for a bountiful harvest.

But the parasite is not yet done with its stricken host. All this growth of mycelium has been but a preparation for the development of the reproductive spores, just as the growth of the mushroom mycelium beneath the soil surface is but a preparation for the sending up of

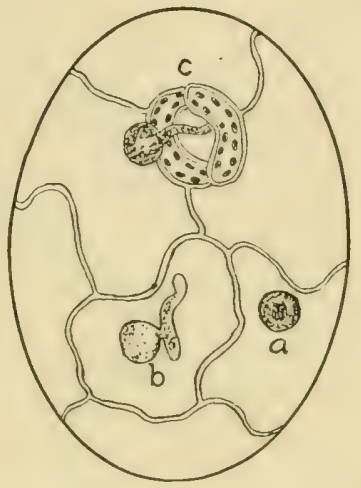

SPORES ON LEAF. Magnified: $a$, spore; $b$, spore germinating; $c$, spore with germinating tube entering breathing pore the spore-bearing mushroom. The mycelium in the leaves sends out to the surface vertical branches that bear upon their tips the tiny summer spores. These mature quickly and are readily carried away by the slightest breeze. Thus the disease is able to spread rapidly by means of the billions of spores produced. This development of summer spores begins soon after the mycelium gets well started, often before the whole leaf is affected. Many of these spores are likely to be washed through the soil till they reach the tubers, and they may develop there, causing a characteristic brown discoloration.

This fungus commonly passes the winter by means of 
the mycelium in the diseased potatoes. When they are planted, a new crop of spores apparently is produced, either on the seed potato itself or upon the stalks and leaves that grow from it. Many of the downy mildews have special winter spores by means of which the fungus lives from one season to another, but these seem not to have yet been certainly found in this species affecting the potato.

The best methods of controlling Potato Blight are the planting of tubers from fields in which the disease was not present, spraying with Bordeaux mixture, rotation of the crop, and the selection of resistant varieties.

When a parasitic fungus attacks one plant, it is very likely to attack other closely related plants. The tomato is closely related to the potato. Consequently it does not seem strange that there is a Tomato Blight caused by the same fungus that causes the Potato Blight. It is often destructive in wet summers in the Eastern states and during damp winters in southern California. Rotation of crops and spraying with Bordeaux mixture are effective preventive measures.

\section{Other Downy Mildews}

A parasite closely related to the Downy Mildew of potatoes is the Downy Mildew of Lima Beans. This at times is very destructive in many parts of the United States, sometimes greatly reducing or almost destroying the crop. It appears as a thick white covering upon the pods, injuring the tissues of the wall and often extending the damage to the young beans inside. It spreads chiefly by means of summer spores, and apparently passes the winter in the seed in the form both of dormant mycelium and of distinct winter spores. 
The chief preventive measures are the planting on high land of seed gathered from a field where the mildew was not present, the rotation of the crop, the destruction of all old bean vines, and spraying with Bordeaux mixture.

The Downy Mildew of the Onion is a widely distributed disease that causes serious loss in some parts of the United States nearly every year. It attacks the leaves, at first causing a yellowish discoloration that may later show the white threads of the fruiting fungus. Vast numbers of summer spores enable the disease to spread rapidly during the growing season, and well protected winter spores enable it to live through the winter in dead leaves or in the soil. These winter spores appear to be able to survive in the soil for two years. Consequently a crop rotation in which onions are not grown on the same land oftener than once in three years is desirable. Clean culture, burning of diseased leaves, and spraying with fungicides are also helpful.

Another Downy Mildew is often destructive to cucumbers, melons, and squashes. It is likely to destroy the vines in almost any region when warm clamp weather farors its rapid growth. It seems to do as much damage in the South as in the North, or more, and it often appears as an active epidemic quickly blighting the vines over great regions. The white mildew that gives off millions of summer spores shows on the under surfaces of the leaves.

Clean culture, burning or deep burying of infested plants, rotation of crops, and spraying with fungicicles are the chief remedial measures against this disease.

Among the numerous parasitic enemies of the grape the Downy Mildew or Brown Rot is at times one of the most destructive. In its life history it does not differ essentially from the other Downy Mildews. It reproduces in summer 
by summer spores and passes the winter in the form of winter spores. It attacks leaves, young stems, and green fruits, causing a mildew-like growth on the former and a brown rot of the latter. It is prevented by spraying with Bordeaux mixture.

The Brown Rot of the Lemon has recently become a destructive disease in California. The fungus attacks the rind of the lemon, causing a brownish discoloration and a characteristic odor. It is likely to spread through the fruit of boxes in storage or in transit, so that it often causes serious and unexpected losses. The spores are produced on the ground and not on the lemons, but they often reach the latter through the water in which the fruit is washed. Consequently, one desirable measure of control is the disinfection of this water by the addition of a small amount of formalin or some other germicide. Full details of treatment may be found in the bulletins of the California Experiment Station.

\section{OBSERVATIONS FOR PUPILS}

\section{Mushrooms}

I. Bring in a fresh mushroom or toadstool. Compare it with the picture on page $2 \mathrm{I} 5$. Do you see all the parts there represented?

2. Place a fresh mushroom upon a sheet of paper and leave over night. See if there are spores on the paper in the morning. If so, examine under a microscope.

3. Dig up the soil at the base of the stem of a mushroom to see if you can find the mycelium from which it developed.

4. Look in lawns and pastures to see the "fairy rings" of mushrooms that so often occur. See if you can find out the explanation of the production of such rings.

5. Draw a mushroom and label the parts. 


\section{Downy Mildews}

I. Which of these diseases have you known to be present in your neighborhood?

Downy Mildew or Late Blight of the Potato.

Downy Mildew of the Tomato.

Downy Mildew of the Lima Bean.

Downy Mildew of the Onion.

Downy Mildew of Cucurbits.

Downy Mildew or Brown Rot of the Grape.

2. What preventive measures are used against these diseases in your neighborhood?

3. Make sketches of leaves affected by the disease in the case of such of these as you find.

4. Read Farmers' Bulletin 9I. 


\section{CHAPTER XX}

\section{The Smut Fungi}

THE Smuts form a distinctive group of parasitic plants called by botanists Ustilaginales. The mycelium develops in the tissues of the host plant and causes serious injury to the parts infested. Spores are developed in the form of the blackish powder so characteristic of Corn Smut and Oats Smut. These primary spores germinate under favor-

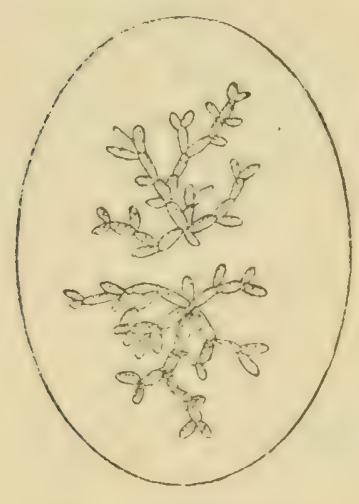

SMUT SPORIDIA

Magnified able conditions and often bring about the development of enormous numbers of secondary spores.

Nearly every one is familiar with the Loose Smut disease which so often affects the heads of oats, causing them to become masses of loose blackish powder instead of healthy kernels of grain. These black powdery masses are composed of millions of the minute spores by means of which the fungus multiplies.

These spores appear on the plants when the oats in the field are blossoming. At that time the seed envelopes which later form the "chaff" - - are spread apart, so that it is easy for the spores to lodge inside them. There the spores remain, even through the threshing process.

The spores that have thus been concealed beneath the chaff remain in position until the grain is planted. The moisture and warmth favorable to the starting of the seed 
also cause these spores to germinate. They send out tiny tubes that penetrate the young oats plant. The threads of the fungus thus get into the growing tissues where they continue to develop by sending out numerous branches that run through all parts of the stalk. An elaborate mycelium is thus formed, and continues to develop along with the growing oats plant.

When the grain begins to send out its heads, the fungus develops a mass of thickened threads within the florets. These threads soon give rise to millions of blackish spores that form the familiar powder of smutted grain.

The spores of this fungus are so minute that the number in a single diseased oats head is almost inconceivably great. It has been estimated that a single cubic inch of the smut powder would contain $64,000,000,000$ spores. Of course, most of these spores never develop.

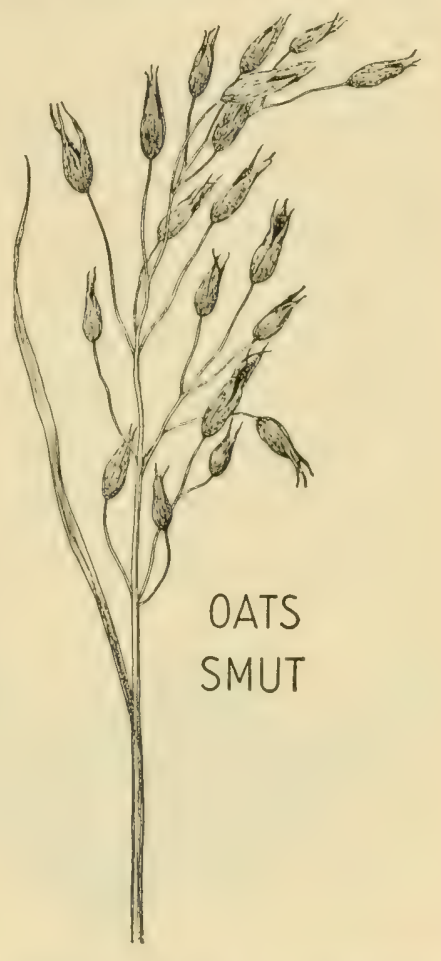
With the lower forms of life, Nature produces vast numbers of reproductive bodies, with the expectation, as it were, that only a small fraction of a per cent will find conditions suitable for continued existence.

Many experiments have shown that Oats Smut may be prevented by soaking the seed in diluted solutions of formalin, thus destroying the spores that cause the disease.

There is another form of smut disease, which is more injurious to wheat than this loose smut, called the Bunt or Illsmelling Smut, because it has a distinctly disagreeable odor. 
With this malady the individual kernels of wheat are affected rather than the whole head. Such kernels appear whitish or bleached in contrast to the yellow of the healthy grains.

\section{Corn Smut and Onion Smut}

The curiously swollen kernels on ears of Indian corn affected by the Smut are probably familiar to every boy or girl brought up in the country. The swelling is due to the growth of a parasitic fungus that develops among the growing tissues, making the plant cells abnormal and finally destroying them. In place of cells of healthy tissue enormous numbers of tiny blackish spores are finally produced. These are the reproductive portions of the parasitic fungus.

These blackish spores are so fine and light that they are readily scattered by the wind or are easily floated from place

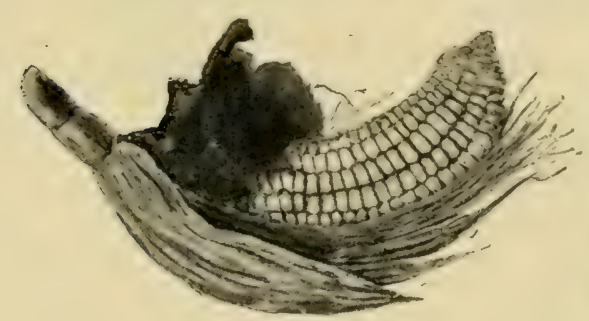

CORN SMUT

to place by running water at times of rain or flood. Under favorable conditions as to warmth and moisture each spore is able to germinate and produce other or secondary spores, which in turn are able to penetrate the tissues of the young corn plant and start the disease anew.

The greatest injury by Corn Smut occurs in gardens where corn is grown season after season and the smutted ears are left upon the soil. The first step in prevention is to destroy promptly all the parts of corn plants that are producing the disease, thus checking the development and dispersal of the spores. Rotation of crops is also helpful.

The sorts of Smuts with which most people are familiar are those affecting grains in which the fruiting kernels show 
the injury most plainly. Some parasitic fungi, however, develop upon the leaves and stems of other plants. The Onion Smut is one of the most important of these. It attacks the leaves and bulbs of seedling onions, giving them a characteristic blackish appearance, and often ruining the crop. The spores develop secondary spores called sporidia in much the same way that other Smut diseases develop.

The Onion Smut is especially troublesome on land in which successive crops of onions are grown. This is believed to be due to the presence of the spores in the soil. Consequently, a wise crop rotation is the first preventive measure. The spores are also easily carried from field to field in the soil adhering to hoes or other tools. Consequently, care should be taken to prevent this, as well as to prevent the washing of the spores from field to field. Clean culture and the deep burying or burning of all infested plants is desirable.

The Smut fungus apparently enters the seedling onions about the time they come up, rather than later. Consequently, onions started in special beds and transplanted are seldom injured.

\section{OBSERVATIONS FOR PUPILS}

\section{Loose Smut of OAts}

I. Have you seen smutted oats heads in fields? How much damage does the disease do in your neighborhood?

2. If there is a compound microscope in school, examine the spores under a high power.

3. Bring in a diseased oats head which has not yet burst open; place the stem in a bottle of water and watch it for a few days to see the production of spores.

4. Make a sketch of a panicle of oats injured by Loose Smut.

5. Read Farmers' Bulletin 250. 


\section{CORN SMUT}

I. In your neighborhood, is Corn Smut more injurious to sweet corn than to field corn? Is it more destructive in gardens where sweet corn is planted in the same place year after year than in gardens where the sweet corn is rotated with other crops?

2. At what time do the first black spores develop on the smutted ears?

3. Do the people of your locality take pains to cut out and burn the diseased plants?

4. Make a drawing of a cliseased ear of corn. If there is a compound microscope in school, make sketches of the spores as seen with a high-power objective. 


\section{CHAPTER XXI}

\section{The Rusts (Uredinales)}

FEw fungous diseases are more widespread in the United States or more readily found in any locality than the Asparagus Rust. This fungus was described in Europe in I 805 and had doubtless existed for ages before that time. As a serious enemy it first attracted attention in the Eastern states in 1896. It spread westward so rapidly that in I90 I it was very destructive in California. Since then it has been generally recognized as the worst obstacle to asparagus culture.

In a way the life history of this rust is typical of the great family to which it belongs. It passes through the winter in characteristic spores attached to old leaves and stalks, or lying loose upon the soil surface. These are called the Winter Spores or teleutospores. They are stalked, double-celled spores of curious and characteristic form.

In spring these teleutospores germinate as they lie upon the ground or upon the standing or fallen asparagus stalks. The contents of each cell break through the cell wall and run out in the form of a long tube. At the end of the tube four partitions develop, so that four distinct cells are formed. Then the material in each cell is sent out to form a tiny secondary spore or sporidium (plural sporidia).

These sporidia are so small and light that they are easily blown about by the wind. When one of them chances to alight upon the green surface of a young asparagus plant 
wet with dew or rain, it sends out a germinating tube that penetrates the outer skin, generally through a breathing pore, and starts a growth of fungus threads or mycelium inside. These threads continue to grow and push in between the green cells of the leaf or stem, absorbing nourishment from them.

After a short time the early spring mycelium has absorbed so much material from the green cells that it is able to develop a new set of spores. A special growth of the fungus threads occurs at certain places just below the outer skin,

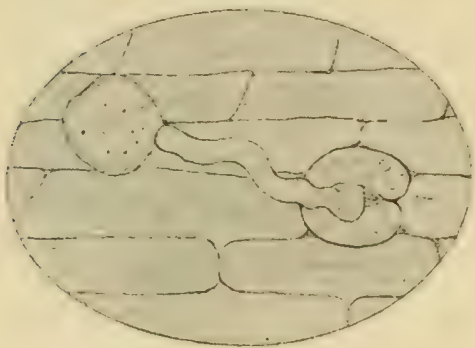

SPORE GERMINATING WITH 'TUBE ENTERING STOMATA; SFEN FROM ABOVE

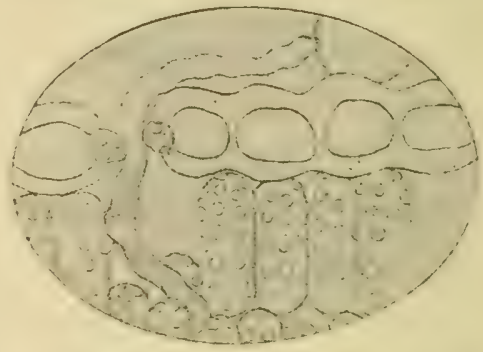

Germinating TUbe among CELLS OF LEAF; SEEN FROM SIDE

which becomes swollen with light green spots. Soon the skin breaks apart and the fungus threads produce great numbers of small round spores. The small swollen places where these spores are produced are called cecidia (singular, acidimm), and the spores produced in them are called ecid$i a l$ spores or spring spores, because they develop in spring.

These spring spores are scattered broadcast by the wind. When one of them chances to alight upon the green surface of a moist asparagus plant, it sends out a germinating tube that penetrates the tissues in much the same way that the germinating tube of the sporidium did at the beginning of the season. On the inside the germinating tube continues to grow, forming new fungus threads that absorb the life 
substance of the previously healthy cells. After a time this mycelium is ready to produce spores again, and it causes more tiny swellings upon the green surfaces of leaves and stems. The skin of the swollen dots soon breaks apart, revealing swarms of tiny rust-colored spores. These are the uredospores or summer spores. They give the familiar rusty color to diseased asparagus plants. They are produced in untold billions, to be scattered by the wind from plant to plant and from field to field.

When they alight under conditions favorable to growth, they start the disease anew. These summer spores are the chief means for the general dispersal of the rust. Like the spores produced in spring, they are unable to survive long in a condition to germinate.

As autumn comes on, if the asparagus host plant becomes weakened from any cause, the mycelium in the leaves and stems produces yet a third kind of spores - the black rust or winter spores with which our little story began. These are called tclcutospores: they develop in great numbers in swollen pustules, their black color giving this stage the name black rust to distinguish it from the orange rust of the uredospore stage.

These two celled teleutospores have comparatively thick walls which enable them to survive the winter and start the disease anew in the spring.

To summarize this story of the yearly cycle of the Asparagus Rust:-

I. It winters in the black rust or teleutospore stage.

2. In spring the teleutospores germinate into secondary spores called sporidia.

3. These sporidia infect asparagus plants and start in the tissues of leaf and stem a growth of fungus threads or mycelium. 
4. This mycelium soon produces certain swellings or pustules called æcidia from which spring spores or æcidiospores are developed.

5. These æcidiospores spread the disease and start more mycelium.

6. In summer the mycelium produces other pustules from which the orange-colored summer spores or uredospores are developed.

7. These uredospores spread the disease far and wide, starting more mycelium from which more uredospores are developed.

8. In autumn the mycelium in the tissues produces black pustules from which the winter spores or teleutospores are developed, thus completing the yearly cycle.

Even in a slightly infested asparagus field there are millions of teleutospores each spring. If each of these develops eight sporidia, there are of course enormous numbers of the latter produced. These sporidia are short-lived, however, and each must soon find a living asparagus plant if it is to start the disease anew. In established fields the asparagus is cut and carried off almost as soon as it comes up. Consequently, there is little chance for the rust to get a foothold there. The asparagus plants upon which the disease grows in spring are generally chance seedlings in neglected corners or those newly planted fields in which cutting has not been begun. It is important, therefore, to destroy wild asparagus plants, for they help to tide the disease over the weeks of spring.

\section{Clover Rust}

The Clover Rust is similar in its yearly history to the Asparagus Rust. It has the same three kinds of spores 
succeeding one another, and is found upon both red and white clovers. It is a widespread disease, but seldom does serious injury.

Another closely related fungus is Alfalfa Rust, but this as a rule causes only a minor injury. The pustules showing the summer spores are likely to be found upon alfalfa leaves at any time in summer.

The Rose Rust is still another species having a life story similar to that of the Asparagus Rust. It is very frequently found upon the leaves and stems of roses. Other rusts occasionally occur upon beans and beets.

\section{Wheat Stem Rust}

The Asparagus Rust is typical of the rusts that pass their various stages upon one host. There are many others, however, in which the fungus develops part of the year upon another host, so that the life history may seem even more complex than that of the Asparagus Rust.

The Stem Rust of Wheat is a good example of a rust that lives upon two hosts. Most people in regions where wheat is grown are familiar with the slender black spots on the leaves and stems of ripened wheat. Under a lens these are readily seen to consist of teleutospores, similar to the teleutospores of the Asparagus Rust. They serve as the winter spores of the Wheat Stem Rust, living through the winter wherever the straws may be.

In spring the teleutospores germinate by sending out tubes, and these tubes in turn give rise to secondary spores called sporidia exactly as in the case of the Asparagus Rust.

These sporidia are blown about by the wind. If one chances to light upon a moist barberry leaf, it germinates and sends its fungus thread through a breathing pore into 
the tissues of the leaf. Here it develops into a mycelium that soon produces swollen orange-colored pustules, often called cluster cups. In these pustules the mycelium develops æcidiospores or spring spores which in turn are blown through the air by the wind. This is often called the cluster-cup stage of the rust.

Some of the æcidio spores are likely to find lodgment upon the leaves or stalks of wheat plants. When moisture from dew or rain is present, these will germinate and start a growth of mycelium in the tissues. This mycelium will soon produce a crop of rust-colored uredospores or summer spores which scatter through the wheat fields and spread the disease rapidly. This process continues through most of the summer, and consequently this is the stage in which the most damage is done by the rust fungus.

Finally, as the wheat matures the mycelium in the tissues gives rise to the black rust or teleutospore stage. In this condition it passes the winter.

\section{Yearly Cycle of Wheat Stem Rust}

I. Early Spring.

a. Teleutospores develop sporidia.

b. Sporidia are blown to barberry.

c. Sporidia develop mycelium in barberry leaf.

II. Late Spring.

d. Mycelium in barberry leaf develops æcidiospores.

e. Æcidiospores are blown to wheat.

$f$. Ecidiospores develop mycelium in wheat.

III. Summer.

g. Mycelium in wheat develops uredospores.

h. Uredospores are blown to other wheat plants.

i. Uredospores develop myceilum in these wheat plants.

IV. Autumn.

$j$. Mycelium in these wheat plants develop teleutospores that live through the winter. 
If you will compare this yearly history of the wheat rust with that of the asparagus rust, you will see that the chief difference is that the sporidia develop upon another host from which the xcidiospores return to the wheat plant. This difference is typical of many other rust fungi, and special names are given to indicate the group to which the various sorts belong:-

When the different stages of a rust fungus develop on one kind of plant, it is said to be an autacious species; example, the Asparagus Rust.

When the different stages of a rust fungus develop upon two or more kinds of plants, it is said to be a hetercecions species; example, the Wheat Stem Rust.

The stem-rust on wheat and barberry is the typical example of a heterocious rust. It is interesting because of the alternation of host plants and because all three forms of spores are present. The Black Stem Rust, however, often occurs in regions where barberries are either rare or not found at all, and there is no doubt that the fungus can live from year to year without going through the clustercup stage on barberry.

\section{Other Grain Rusts}

There are other rusts of grain even more destructive than the Wheat Stem Rust. The Orange Leaf Rust of Wheat is perhaps the worst of these. Technically it is called Puccinic mbigo-vera. It is believed by good authorities to be the most abundant of all grain rusts in the United States. The uredospore form is the one generally present, and in the South at least the fungus can live through the year with no other spores present. Teleutospores have been found, but the æcidium stage is unknown. 
The Crown Rust or Orange Leaf Rust of oats is an abundant and widespread disease. Technically it is known as Puccinia coronata. It has a life history very similar to that of the Black Stem Rust, the spring spores or xcidiospores being developed upon buckthorn instead of barberry. There seems little doubt, however, that the fungus can pass through the year in the absence of this æcidium stage.

Serious injury by the Rust of Indian Corn is only rarely reported, although the fungus is very common. It appears on the leaves in brownish pustules of uredospores that develop during summer. They are followed later in the season by blackish teleutospores which live over winter to start the disease anew in spring. This fungus is known as Puccinia Sorghi.

\section{Cedar and Apple Rust}

Another good example of a heterocious rust is the one that causes the "cedar apples" so often found on cedar trees. These are curious little orange-colored balls that occur along the twigs. In autumn and winter they have smooth, rounded surfaces, but in spring they send out curious jelly-like masses about half an inch long. The teleutospores germinate by sending out tubes that give rise to secondary spores or sporidia. These sporidia are blown about by the wind: such as fall on moist leaves of apple, quince, or June-berry are likely to germinate and start a growth of mycelium within the leaf.

This mycelium soon gives rise to swollen pustules called cluster cups or æcidia. In these millions of brownish æcidiospores are developed. These are blown about by the wind, and such of them as chance to light upon moist 
cedar branches germinate and start a growth of mycelium in them. There appear to be no uredospores and no spreading of the disease to other apple trees by the æecidiospores.

Consequently, in this case of the Cedar Apple and Apple Rust we have but two distinct forms instead of the three in the case of the Black Stem Rust.

Thus :-

I. Cedar Apples on Cedar.

Teleutospores develop sporidia to go to apple leaves.

2. Apple Roust.

$A$. Sporidia cause mycelium that produces acidia containing æcidiospores.

B. Acidiospores go to cedar trees to develop cedar apples.

The mycelium in the cedar trees is perennial, living from year to year and producing each season new cedar apples to send out sporidia. Consequently, the destruction of the cedar trees is helpful in preventing the development of the Apple Rust.

\section{Other Rusts}

The Orange Rust of blackberries, dewberries, and raspberries is one of the most conspicuous and widespread members of the family. It affects both wild and cultivated plants and is found wherever these fruits grow. The conspicuous orange-colored æecidiospores appear in spring and early summer, and are followed later by a crop of uredospores, and these in turn by the teleutospores. The prompt burning of all infested canes is very desirable.

A characteristic leaf rust, known technically as Puccinic Prini, commonly affects plums, peach, and other stone 
fruits. It is seldom seriously destructive. The only spore. forms known are the summer spores and the teleutospores, both being of the brown color so general in the rusts.

During the last quarter of the nineteenth century the Hollyhock Rust was very destructive in the United States. It is still a pest, but less so than formerly when it caused the culture of hollyhocks to be almost abandoned. There is good reason to hope that resistant strains of Hollyhocks will soon be developed.

The Hollyhock Rust appears as brownish pustules on the under surface of the leares. These contain an abundance of two-celled teleutospores, and it is an interesting fact that in this form of rust fungus this seems to be the only form of spore that occurs. The teleutospores are also remarkable for their ability to germinate at once instead of resting through the winter as do most of the teleutospores. Consequently, in this case the teleutospores are both summer spores and winter spores. The gathering and burning of affected leaves is a helpful remedial measure.

\section{OBSERVATIONS FOR PUPILS}

\section{Rusts}

I. Which of the following rusts do you find in your neighborhood?-

Apple Rust

Asparagus Rust

Bean Rust

Beet Rust

Clover Rust

Corn Rust
Hollyhock Rust

Oat Crown Rust

Plum Rust

Raspberry Rust

Wheat Leaf Rust

Wheat Stem Rust

2. Set aside a page of your booklet for three of the most important of these rusts, and write a brief account of your observations upon each. 
Perhaps this outline will help :-

The name of the disease.

Its abundance and the amount of damage it does.

The parts of the host plant most affected.

How it passes the winter.

The preventive measures used against it in your neighborhood.

3. Press a few leaves or stalks showing each of the rusts common in your locality. Mount them on pages of your booklet.

4. Read the discussion of Grain Rusts in Farmers' Bulletin 219. 


\section{CHAPTER XXII}

\section{The Ascospore and Other Fungi}

A NUMBER of parasitic fungi are classified together in a group called Ascomycotes because the principal spores are developed in special tubular spore cases called asci; these spores are called ascosporcs. They often serve as a means by which the fungus passes through the winter; so they are sometimes spoken of as winterspores. The fungus may also develop more temporary spores which are often spoken of as conidiospores or summer spores.

\section{BLACK KNOT}

Most schoolboys have seen the branches of plum and cherry trees distorted by a black, knotty growth, having the appearance of the picture on the opposite page. Wild cherry trees very commonly show the injury, which is produced by the fungous disease known as the Black Knot. The knots are caused by the growth of a parasitic fungus in the twigs or larger branches. They first appear as swollen places on the bark. These enlarge and cause irregular cracks which are characteristic of the disease. Finally the whole circumference of the twig may be affected so that the part beyond soon dies.

During warm weather vast numbers of summer spores are produced upon the bark of the knots. These give the affected part of the tivig a soft, velvety surface of a dark olive color. These spores are blown from place to place. 
Those that fall upon green and tender bark are likely to germinate and start the disease again.

As cold weather approaches, the tissues of the outer bark become much harder, with many little cavities inside. The fungus produces within these cavities spores that germinate the following spring and start the disease anew.

The Black Knot affects most varieties of plum and cherry trees, both wild and cultivated, and the spores are easily carried from one sort of tree to another. Consequently, it is important that in any locality all traces of the fungus should be exterminated. The cutting down of worthless trees and the pruning away of diseased branches are the first steps in the control of Black Knot.

The cutting out of the injury as

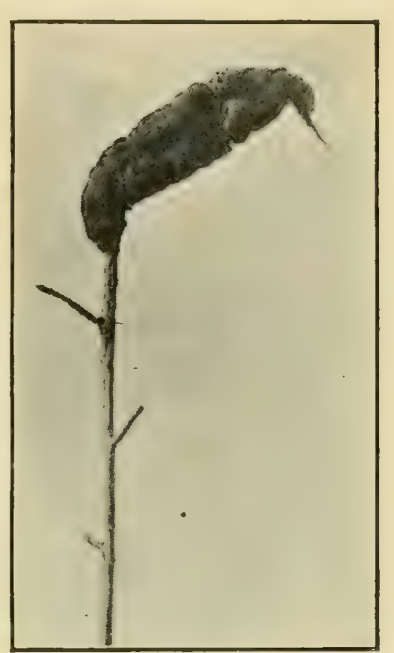

BLACK KNOT ON WILI) CHERRY; WINTER CONDITION soon as it appears and spraying with fungicides will also help to control it.

\section{Peach Leaf Curl}

Peach Leaf Curl is the name applied to a malady that often affects the twigs and leaves of peach trees. It causes the leaves to swell and curl soon after they expand in spring, giving them an abnormal appearance that is at once recognized as due to a diseased condition. The threads of the fungus penetrate between the cells, growing rapidly and causing a swelling of the tissues. The injured leaves fall off in the spring or early summer. The twigs affected also become swollen and distorted. Sometimes the disease is confined to a branch or two, but frequently it involves 
the foliage of the whole tree. In such cases the young peaches are likely to drop off, and the crop be thus destroyed. A new set of leaves will be put forth, but of course the tree will be unable to produce the same season another crop of blossoms and young fruit.

Fortunately this disease is readily prevented by spraying with fungicides. Winter treatment with Bordeaux mixture or the lime-sulphur wash is an effective remedy. This is believed to be due to the fact that the spores of the fungus pass the winter chiefly on the bark and buds of the trees, so that they are killed by the fungicide.

\section{Plum Pockets}

The Peach Leaf Curl is due to the growth of a parasitic fungus that belongs to the genus Exoascus. The fungi of this genus cause abnormal growths of the plants they infest. The curious "witches brooms" often seen upon birch and other trees are due to these parasites. So, also, are the strangely swollen plums often seen upon the plum trees and commonly called Plum Pockets.

Young plums are generally affected by the Plum-pocket disease. They become swollen, and when cut open are seen to be hollow, with no pit. After a time they are likely to be covered with a powder composed of the microscopic spores of the fungus. These spores are widely scattered by wind and rain, and presumably infest other trees, though just how this is done is not now known.

It is known, however, that the threads of the fungus live from year to year in the twigs and reach the young fruits by growing through the blossom or fruit stalks. When a branch is once infested, it bears the Plum Pockets year after year, and all new twigs sent out by it beyond the point of 
infection do likewise. Consequently it is evident that the threads of the fungus grow along with the new growth of the branch. The best remedy is to cut the branch off, somewhat below the point of infection, thus removing the diseased tissues.

\section{Apple Scab and Pear Scab}

The Apple Scab is one of the most familiar fungous diseases. It appears as black spots, upon the surface of the apple, and also upon the leaves. The spores of the fungus that causes the disease are produced in great abundance on these blackened spots. They are scattered far and wide by wind and rain. Those that

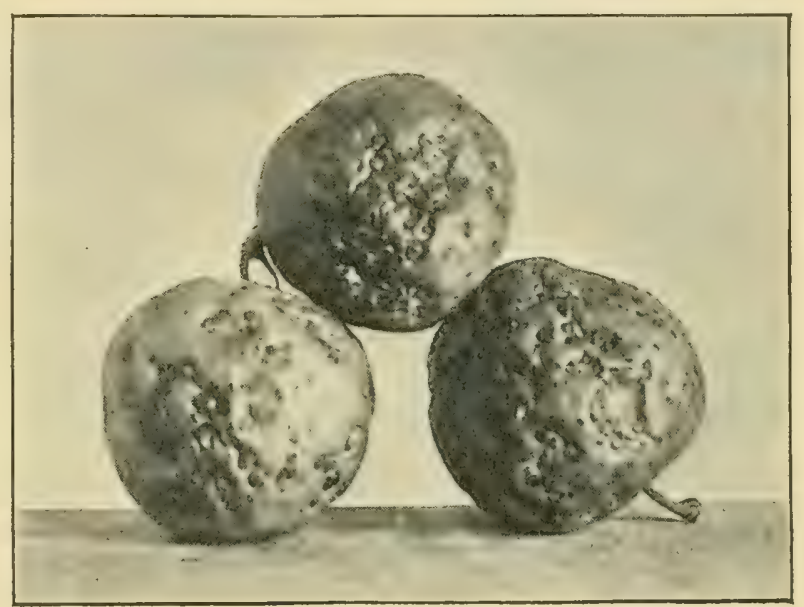

APPLE SCAB lodge upon the leaves or fruits of apple trees germinate during moist weather by sending out little tubes and thus start the disease anew.

The growing portion of the fungus consists of brownish cells. After a time the cells multiply and push outward, exposing a surface in which the small oval spores develop. These spores live through the winter on the bark, twigs, and stored apples, as well as on the fallen leaves and fruit.

The Apple Scab fungus not only causes the apples to appear unsightly and injures them for food, but it also pre- 
vents them from growing to as large a size as they would if not affected. The extent of this dwarfing is illustrated in the figure below. The disease may be prevented by spraying with fungicides, the self-boiled lime-sulphur wash being one of the best for this purpose.

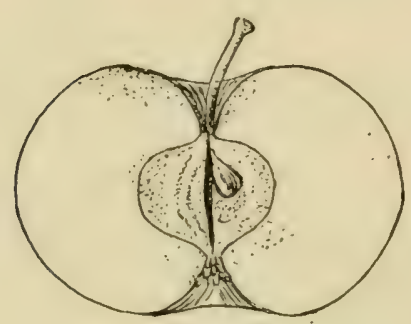

DWARFED BY APPLE SCAB

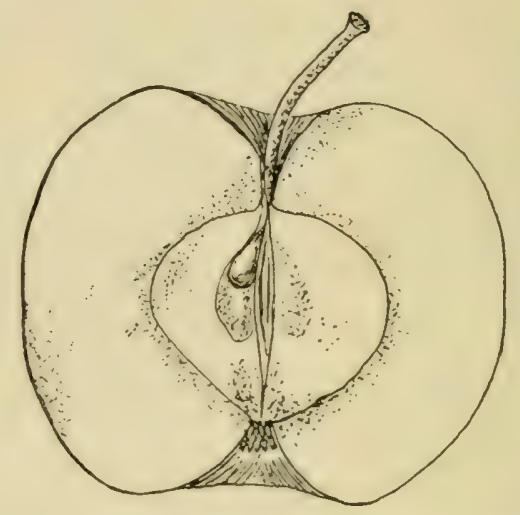

A closely related fungus causes the Pear Scab, which is often destructive to certain varieties of pears. Its life history and control are practically the same as the Apple Scab.

\section{Bitter Rot of Apple}

This disease causes losses of millions of dollars in the United States almost every year. It is generally noticed upon the fruit, especially as it approaches full size. Small brownish spots may be seen at first; these gradually enlarge and commonly spread over much of the apple, causing it to fall. Many of the smaller fruits, however, remain upon the tree, shriveling to a mummified condition, in which they may hang to the twigs until the next spring.

After the mycelium of the fungus has been growing in the fruit tissues for a time, it develops upon the surface characteristic blackish pustules in which great numbers of 
spores are produced. These are scattered by wind and rain and serve to spread the disease to new fruits. The mycelium gives a bitter taste to the parts of the apple near the decayed spot.

This fungus is also able to develop upon the bark of apple trees, where it produces dead blotches called cankers. The fungus apparently passes the winter both in these cankers and in the mummied fruits, from which new crops of spores are produced in spring or early summer.

The destruction of mummied and fallèn fruits, cutting out and burning all canker

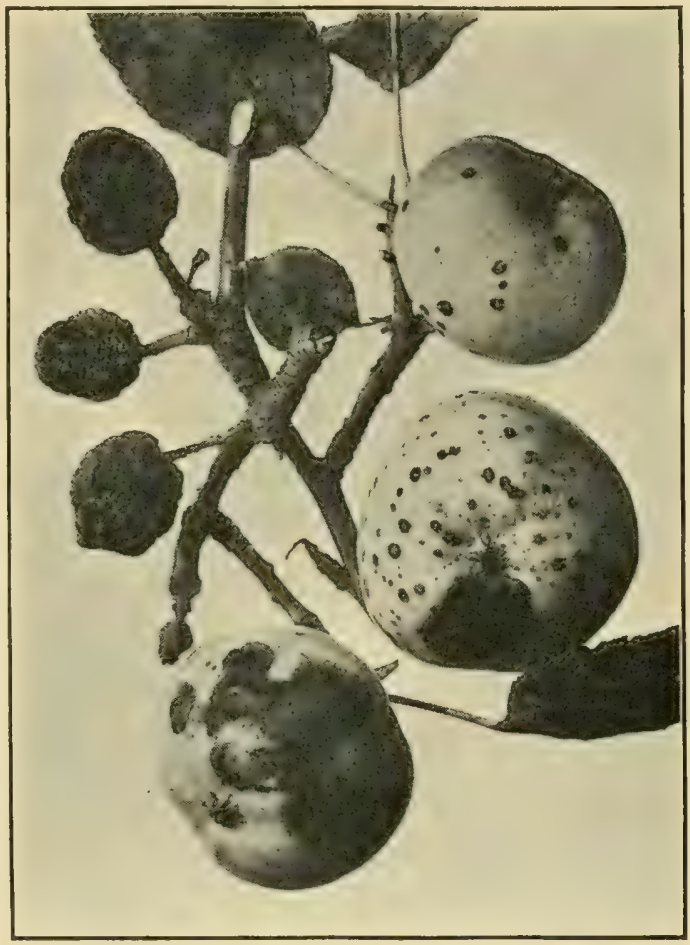

APples AFFECTEd BY BitTer Ro'T spots, and spraying with fungicides are the means by which this disease may be controlled.

\section{Brown Rot of Stone Fruits}

The Brown Rot of peaches, plums, and cherries is one of the most destructive diseases affecting fruits. It is the commonest cause of the rotting of peaches or plums both upon the tree before or during ripening, and also in the baskets after picking. Its life history is similar to that of the other fungi that cause plant diseases. The tiny spores 
blown upon the damp fruit send out their germinating tubes into the tissues where they grow, branching in all directions. These branches absorb the cell contents. In

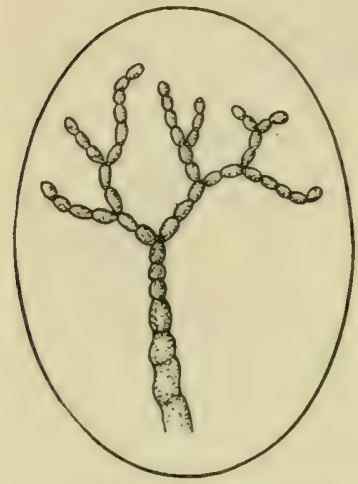

BROWN ROT SPORES DEVELOPING Magnified this way the green tissues are broken down, the light green color is turned to brown, and the so-called rot appears. On the outside, the fruit first turns brown in one or two places, then more and more of the surface appears affected, until finally the whole surface shows the injury.

Soon after the fruit has thus become discolored, it is likely to show a curious velvety coating - more or less grayish in color - that is made up of millions of tiny spores. They are produced by the threads of mycelium that have been developing amid the tissues of the fruit. Under the microscope they are easily seen to resemble the figures below.

These spores are blown everywhere by the wind and serve to spread the disease very rapidly. A single affected fruit may furnish millions of spores for the wind to sow broadcast over the surrounding country.

Unless the diseased fruits are removed, many of them remain upon the tree. They shrivel slowly into dry and mummied fruits inside which the threads of mycelium develop into blackish bunches that correspond in a way to winter spores and enable the

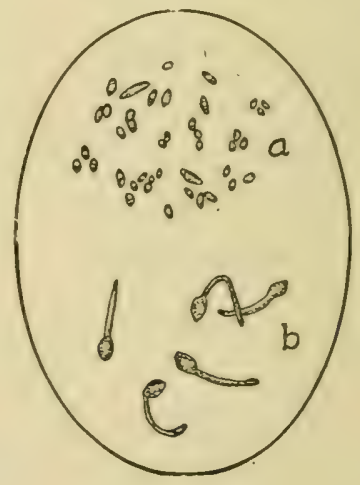

BROIVN ROT $a$, spores ; $b$, spores germinating; magnified fungus to survive the winter, and to produce a new crop 
of spores in spring. These are likely to develop in the tissues of the buds, blossoms, and young twigs, often causing serious damage.

Sometimes a curious mushroom stage of the fungus develops in connection with the mummied fruits upon the ground. Great numbers of tiny mushroom-like objects develop from the mycelium. In these the winter spores or ascospores are produced. Apparently this stage is not generally present, and is not necessary to the yearly cycle of the fungus.

Evidently one of the chief preventive measures with this disease is the gathering of all the mummied fruits in winter. By doing this, by thinning the fruit, and by spraying with self-boiled lime-sulphur wash, most of the injury may be avoided.

\section{Pear Leaf Blight}

The foliage of pear and quince trees often becomes spotted with brown in summer, and the spotting sometimes is so extensive that the leaves turn brown and fall off. When this occurs over the whole tree and is not at first confined to a single branch, it is generally caused by a fungus that attacks the leaves early in the season and continues to develop until the end of summer, causing the disease known as the Pear Leaf Blight. This fungus is a distinct species of parasitic plant which at first causes small reddish spots to appear upon the leaves. These spots gradually grow larger and turn brown and often cause the whole leaf to become brown and dead. The fungus also develops upon the fruit, causing it to crack open. Fortunately this disease may be almost entirely prevented by spraying with fungicides. 


\section{Strawberry Leaf Spot}

Every one who grows strawberries has noticed the brown or reddish spots that appear upon the leaves, especially late in summer. These are due to a fungous disease called the Strawberry Leaf Spot. When the spots first appear, they may be seen on the upper side of the leaf as small dots of a purple or reddish color. They grow larger from day to day; the central portions become brown in color, while the margins retain their purple hue. The fungus threads within the cells of the leaf generally affect a circular area, but frequently two or more centers of disease will be sufficiently near each other to run together and produce a large discolored blotch. Sometimes practically the whole leaf will be destroyed. The effect of the disease upon the plant is to dwarf its growth and lessen the fruit crop produced the succeeding year.

The Strawberry Leaf Blight may be prevented to a considerable extent by spraying with the Bordeaux mixture. Of course this cannot be applied while the berries are on the vines. An excellent way to treat fruiting plantations is to mow the vines after the berries are gathered, and burn the ground over as soon as the leaves are dry. This destroys the spores of the fungus and a new crop of leaves will soon be produced comparatively free from blight, especially if they are sprayed once with the Bordeaux mixture.

The most successful growers of strawberries renew their plantations every year, as they find it easier to set out a new bed than to clean out an old one. When this method is adopted it is seldom necessary to spray to prevent the Leaf Spot. 


\section{Black Rot of Grapes}

The Black Rot of grapes is one of the most destructive plant diseases. It often causes the loss of a large part of the crop in many vineyard regions and is generally recognized as a dangerous enemy. The disease is caused by a fungus that passes the winter in mummied grapes and is believed to start in spring from ascospores developed in them. It appears in spring or early summer on young leaves and branches, producing a brown discoloration. Later it shows on the green grapes as brownish spots that spread over the whole surface, finally producing a blackened fruit that is appropriately described as affected by Black Rot

On the surface of these diseased grapes enormous numbers of summer spores are developed. These are scattered through the vineyard by wind and rain. Whenever one rests upon a moist grape, it is likely to start a new disease spot. In this way the disease may spread very rapidly and cause great loss.

Clean culture and the destruction of dried grapes that carry the fungus through the winter are desirable preventive measures. Spraying with Bordeaux mixture has repeatedly been shown to be an efficient remedy.

\section{CotTon Wilt}

Among the numerous enemies of cotton that have become seriously destructive during recent years, the Wilt Disease is especially notable. It occurs over a large part of the cotton-growing region in the Southern states. The affected plants are commonly stunted in their growth for some time before they finally wilt as if from lack of water. This is in fact the case, because the channels through 
which the water reaches the leaves are clogged by the growth of the parasitic mycelium.

The careful studies of several botanists show that the fungus which causes the disease is commonly present in the soil of cotton fields, where it is able to live long periods as a saprophyte - getting the materials of growth from decaying matter in the soil. When cotton is planted, however, it commonly becomes a parasite by invading the tissues of the plants. The same or a very similar fungus causes a wilt disease in watermelons and in the cowpea.

The only successful method of preventing this disease now known is that of planting varieties that can resist its attack. Much progress has been made in the development of such varieties, and there is reason to believe that still greater progress will be made in the near future.

\section{The Powdery Mrldews}

From midsummer until autumn one can find curious whitish patches upon the leaves of a great variety of trees, shrubs, and herbaceous plants. In some cases there are but small spots of white upon the green background of the leaf blade, while in others the whole surface may be whitened and more or less powdery in appearance. As autumn approaches tiny brownish or blackish spots appear upon the whitened part. Such whitened leaves are very common upon lilacs, roses, willows, red maples, hardy phloxes, and many other plants. They are especially likely to be found on leaves growing in the shade. Such leaves are probably affected by some form of those parasitic fungi called Powdery Mildews. These are among the most characteristic of the ascospore fungi, and form a very distinctive family. 
If you will look through a lens or the lower power of a compound microscope at one of the leaves thus affected, you will see that the whitish appearance is due to vast numbers of tiny threads that run over the surface of the leaf, interlacing in a most interesting fashion. You will find that the brownish or blackish dots are well-developed spore cases - technically called perithecia — often having curious projections from the outer wall. You can probably see these cases in all stagres of growth, from the young whitish ones to the mature blackish ones.

If you place a few of the well-developed spore cases on a glass slide in water, cover with another piece of glass, and crush the walls, you will see the spores come out. These spores are inclosed in smaller sacklike cases - the asci.

When the leaves fall in autumn, these black spore cases fall with them, and the spores inside remain over winter to start the disease anew in spring. For this reason they are often called the winter spores.

In spring or early summer the fungus threads get started on the leaves. Unlike many other fungi, the threads do not grow in or between the tissue cells of the leaf, but they remain upon the outside and send curious suckerlike projections in through the breathing pores of the leaf to absorb food from the cells.

During summer, especially before the development of the winter spore cases, the affected leaves often have a powdery appearance. This is due to the development of millions of tiny white spores. Certain threads of the mycelium grow out at right angles to the surface of the leaf, and on their ends produce spores that serve for the spread of the fungus during the warm months. These are called summer spores or conidia. 
A great many different kinds of powdery mildews are found upon wild and cultivated plants. One of the most abundant of these is the Cherry Powdery Mildew, which occurs also on apples and other fruits. It is especially destructive to young trees in nursery rows. The Gooseberry Powdery Mildew is another widespread and destructive disease. It is especially likely to attack English varieties of gooseberries when grown in America. The Grape Powdery Mildew is also more or less injurious over most of the United States, and the Powdery Mildew of the Bean is likewise widely injurious.

The powdery mildews live externally upon the leaves and stalks of plants more than is the case with most parasitic fungi. Hence we would expect that they could be easily prevented by spraying with fungicides, and this is true. These mildews are checked by applying almost any of the fungicides.

\section{Other Fungous Diseases}

A considerable number of fungous diseases are due to parasites, the complete life histories of which have not yet been discovered. Such fungi are commonly classified under the heading Fungi Imperfecti or Imperfect Fungi. The imperfection, however, is found chiefly in our lack of knowledge. As the diseases are more carefully investigated, the parasites are being transferred to the various groups to which they belong.

The Potato Scab is one of the most important of these diseases. It is caused by an inconspicuous fungus that in freshly dug potatoes may often be seen as a coating of fine white threads over the scabby surface. The disease occasionally occurs upon beets and other root crops. Spores are produced among these threads. It is now well estab- 
lished that on potatoes this disease may be prevented by rotation of crops and soaking the tubers to be planted in a solution of formalin of the strength of one ounce to two gallons of water.

From the viewpoint of geographical distribution, the Early Blight of the Potato seems even more important than the Late Blight. The former is distributed throughout the United States, while the latter is chiefly destructive in New York and New England. The Early Blight appears about the time the plants blossom, showing as small brown spots scattered over the leaves. Sometimes the spots enlarge and run together into blotches. The whole plant is often killed long before its time, so that the tubers in affected fields are small, though there is no rotting effect on account of this disease. Fortunately,

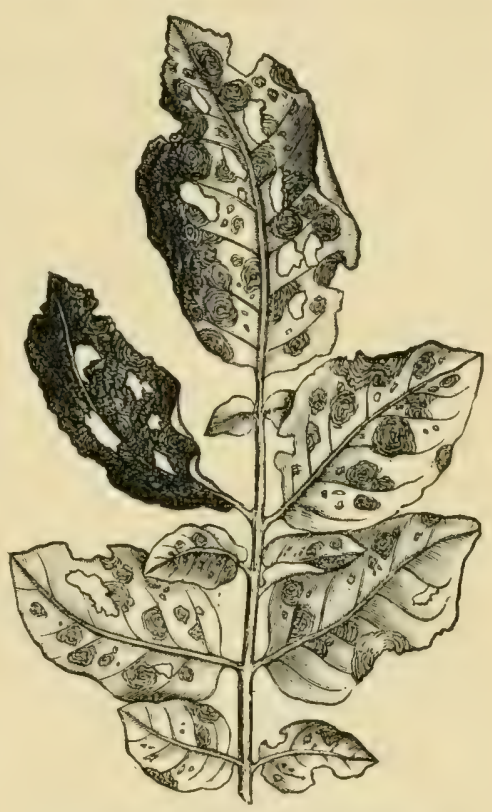

Potato LEAF AFFeCTEN By EARLY BLIGHT spraying with Bordeaux mixture is an efficient preventive.

The Anthracnose of Beans is another widespread and important disease. It is familiar to most people who have attempted to grow string beans, because the reddish brown spots upon the pods are too conspicuous to be overlooked. Sometimes the disease is called the Pod Spot. Such injured pods are generally worthless, and the whole crop is often ruined in wet seasons, for moisture is an important factor in the development of the parasite.

When the pods are seriously affected by the fungus, 
the beans inside are also liable to be affected. If such beans are planted, they are liable to start the disease in the new crop. Consequently, the selection of seed from fields or pods in which the fungus is not present is the most promising preventive measure. It is also desirable to burn infested vines after harvesting as well as to rotate the crop and select for it high, well-drained land.

The Cotton Anthracnose is an important disease in many Southern states. It occurs especially upon the bolls, but also affects other parts of the plant. The injury to the bolls is suggrestive of that upon bean pods, and the affected bolls are likely to result in infected seed.

The Anthracnose of Raspberry and Blackberry is another widespread disease. It produces characteristic reddish purple spots upon the young canes in spring and summer. The centers of the spots later become grayish white, and the spots enlarge, often running together and forming blotches. The spores are developed in dotlike elevations.

The best means of controlling this malady are found in the removal of affected canes, frequent rotation of the plantation, and spraying with fungicides. The self-boiled lime-sulphur wash would seem worthy of trial in an experimental way.

Still another Anthracnose affects green grapes, producing a characteristic injury that is sometimes called Bird's-eye Rot. It occurs upon leares and branches as well as the fruit, but is most destructive to the latter. The destruction of diseased portions is an important preventive measure.

\section{Clubroot of Cabbage}

This disease is caused by a low form of parasitic fungus that is classed with the group of Slime Molds rather than 
the Imperfect Fungi where the diseases discussed in the last few pages are classified. The fungus causes strange malformations of the roots of cabbage, cauliflower, and other wild and cultivated members of the mustard family. It reproduces by spores and is especially likely to develop in acid soils. Consequently liberal applications of lime and rotation of crops are helpful methods of preventing injury. Especial care should be taken not to throw diseased roots upon the compost heap. It is better to burn them.

\section{OBSERVATIONS FOR PUPILS}

\section{BLACK KNOT}

I. Is the Black Knot abundant in your locality ? Does it occur upon wild cherry trees? If so, upon what kind of wild cherries is it most abundant - the choke cherry, the wild black cherry, or the wild red cherry?

2. Notice the difference between the dry or winter condition and the velvety or summer condition of the knots. Feel the velvety coating.

3. If a microscope is available, look at the spores from the velvety surface by means of a high power.

4. What preventive measures against Black Knot are used in your locality? Is there a law in your state requiring property owners to destroy the knots?

5. Do you think that the presence of this disease along roads and fences and in dooryards is a reflection upon the efficiency of your school as an agent for the common good? If so, why not organize a campaign of extermination against the Black Knot?

6. Has one man a right to allow the spores of Black Knot to develop on his trees to be blown to the trees of his neighbors?

7. Make a careful sketch of a twig, showing Black Knot, for your booklet.

\section{Powdery Mrldews}

I. Look at leaves of lilac, willow, and other plants to find those affected by the whitish covering of the Powdery Mildews.

2. Bring such leaves to school and study them as directed on pages 
253-254. See if you can distinguish the summer spores and the winter spore cases.

3. Make a list of the Powdery Mildew diseases that you know to occur in your locality.

4. Make a list of remedies that are used in your locality to prevent injury by these diseases.

5. Make sketches of the fungi as seen through the microscope, also of leaves showing spots where the fungus is present.

\section{Cotton Diseases}

I. Learn what diseases are most destructive to cotton in your region. Collect specimens.

2. Read such of these references as your teacher directs : -

Farmers' Bulletins 302, 333.

\section{Other Diseases}

I. How many of the following cliseases are you able to find in your locality? -

Peach Leaf Curl.

Plum Pockets.

Strawberry Leaf Blight.

Brown Rot of Stone Fruits.

Black Rot of Grapes.

Bitter Rot of Apples.

Apple Scab.

Pear Leaf Blight.

2. Write a short account of your observations upon three or more of these diseases. This outline may help:-

The abundance of the disease.

The parts of the host affected: whether leaf, fruit, or bark.

How diseased leaves or fruits look.

How the fungus passes the winter.

Preventive measures.

3. Make sketches showing the characteristic appearance of each disease you write about. 


\section{CHAPTER XXIII}

\section{Bacterial Diseases of Plants}

THE microscopic one-celled plants called Bacteria or Microbes are now known to be the cause of some of the most destructive plant diseases. In a way the life history of these bacteria is simpler than that of many of the fungi affecting growing crops. The bacteria multiply chiefly by a simple division of the cells, each single cell dividing into two cells. This is a very rapid process, however, so that when once within the tissues of a plant the disease-producing microbes spread very quickly. Consequently, these diseases are often called Blights. Another appropriate name for some of them is Bacteriosis.

\section{Pear Blight}

One of the best-known and most characteristic of these bacterial diseases is the Fire Blight of the Pear, Quince, and Apple. The leaves on the branches affected by this malady suddenly turn black as if injured by fire and hang upon the twigs in this blighted condition for some time.

This Blight affects pear trees much more than apple trees and is the most serious obstacle in the way of successful pear culture. It is very generally known simply as the Pear Blight. It has been carefully studied by many scientists, so that the characteristics of the disease are well known. The microbe causing the malady was named Bacillus amylivones by Professor T. J. Burrill of Illinois. 
Drops of viscid liquid are commonly found along the margin of the diseased areas of the bark. These are sivarming with the germs of the Bacillus. Bees and other insects are attracted to these drops, sucking them up and getting myriads of microbes upon their feet and mouth parts.

Many bacteria multiply rapidly in sweet, jelly like liquids. Such a liquid is found in the nectar cup at the base of the pear blossom, and to a less extent on the end of the pistil of the same flower. Should a bee

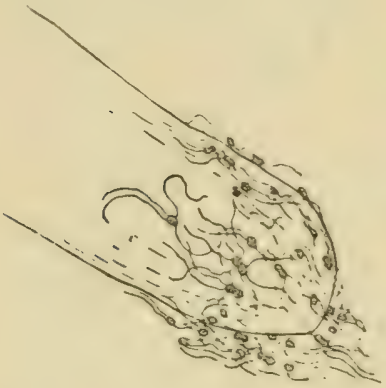

Claw FROM BEE'S FOOT WITH BLIGHT BACTERIA TO SHOW THE RELATTVE SiZE: Highly MagNiflei) visit a diseased tree and get some of the blight microbes upon its feet or mouth parts, and then visit the blossoms of a healthy tree, some of these germs would probably be introduced upon the nectar of the latter.

When thus placed in a position favorable to growth, the bacteria multiply rapidly, and follow down through the stalk of the flower to the twig. Here they continue to develop, and soon may spread downward through the branch. As far as they go they kill the tissues, causing blossoms, leaves, and twigs to turn black.

The germs may also be introduced to new trees through breaks in the bark or by the gnawings of insects. The disease is more severe in trees that grow rapidly than in those that grow slowly. Consequently cultural methods that induce rapid growth are to be avoided. The prompt cutting off and burning of all affected branches, taking care that the germs are not distributed by saw, knife, or shears, is the most effectual remedy. 


\section{Crown Gall Disease}

It is now pretty well established that the widespread disease of fruit trees called Crown Gall is caused by bacteria. This has recently become one of the most destructive maladies of trees, having been widely distributed through nursery stock before its real nature was discovered. This disease appears in spring as an abnormal growth upon the roots of apple, pear, peach, and other trees, as well as those of blackberries and raspberries and various herbaceous plants. The growth continues through the season, often forming large galls of varied shapes. Ordinarily the growth ceases at the end of the first season, and the gall later decays and disintegrates. New galls are likely to appear the next season on other roots in large numbers, damaging the root system so badly that the tree may finally die.

It is easy to see how readily soil could be inoculated with crown-gall germs. If a diseased tree is planted and later dug up, it is probable that millions of the spores will remain in the ground. Consequently great care should be taken not to set diseased plants, and if possible to get plants from nurseries where crown gall is not present.

\section{Cabbage Rot}

The Cabbage Rot is another bacterial disease that has been carefully studied by several scientists in widely separated regions. The malady is especially destructive to cabbages, often ruining large fields. It also attacks cauliflowers, turnips, rutabagas, and various other plants of the mustard family. It has been found on Charlock, a weed belonging to this family, and probably occurs upon other species. 
The fact that the Cabbage Rot is caused by a bacterial germ has been abundantly demonstrated. If you look at cabbage leaves during a season of damp weather, you will probably see a row of water drops along the margin of each leaf. These have come out from small pores, extending from the margin to the veins of the leaf. The leaves are constantly giving off surplus water through the pores; in dry weather the water evaporates as it emerges, but in moist weather it remains to form the water drop.

When one of the tiny bacteria carried in the air by the wind happens to lodge in one of these water drops, it begins to multiply, and soon develops in such numbers that the bacteria enter the leaf through the water pore. Once inside, they travel down the veins, causing injury as they go, until they reach the main stalk. They follow the large channels in this stalk, and sometimes permeate the whole head by pushing along through the system of veins.

The injury done by these myriads of microbes checks the growth of the plant and finally kills it. The germs of other microbes soon enter the injured tissues and cause a vile-smelling rot which effectually completes the work of destruction.

While the Cabbage Rot Bacterium is able to invade healthy plants through the pores, it is often introduced also by the bites of insects. If an insect is feeding upon a diseased cabbage, its mouth parts are likely to be more or less covered with the disease germs. If it then bites a healthy plant, some of these germs will enter the tissues of the latter, and the malady be started anew.

The disease has proved very difficult to overcome. Crop rotation and clean culture are helpful, but they are by no means always effective. The selection of healthy 
plants from the seed bed is important. Warm, moist weather is favorable to the development of the malady. Duggar advises soaking the seed for twenty minutes in formalin solution, one part to two hundred parts water.

\section{Other Bacterial Diseases}

The Bacteriosis or Blight of the Bean and related plants is another destructive disease. It affects especially the pods, producing soft spots with a characteristic watersoaked appearance. More rarely it attacks the stems and leaves. Apparently the disease may be started through infected seeds, so that care to select seeds from blight-free fields is desirable.

The Bacteriosis of melons, cucumbers, and other vines is still another destructive malady. The bacteria develop in enormous numbers in the water channels of the plants, thus preventing water from reaching the leaves, and causing the sudden wilting of the latter. Flea beetles, striped beetles, and other insects help to carry the microbes from plant to plant.

Corn and celery are both subject to bacterial diseases, and cotton bolls are attacked by microbes that cause the Cotton Boll Rot. Potatoes, tomatoes, and eggplants are the victims of another bacterium that causes injury to leaves and tubers or fruits.

\section{OBSERVATIONS FOR PUPILS}

\section{Pear Blight}

I. Have you ever seen pear trees injured by this disease?

2. How did it show itself ?

3. Have you seen blighted apple branches?

4. Read this reference:-

Pear Blight: Its Cause and Prevention, Yearbook Reprint 500. 


\section{CHAPTER XXIV}

\section{Preventives of Fungous Diseases}

In a general way the methods used to prevent injury by fungous diseases come under the head of preventives rather than of remedies. Even in cases where an injured part of a plant is cut off, the aim is to prevent further spread of the disease within the tissues of the plant or to the tissues of other plants. When the fungus has once invaded the cells, there is little hope of remedy so far as the affected part of the host is concerned. In the case of the external mycelium of the powdery mildews, however, the fungicide may have a direct effect.

The various fungicides are really preventives rather than remedies. They kill the spores or mycelium threads upon the outer parts of the plants treated, or they lie in wait to kill whatever spores may come to seek entrance to the tissues. The chemicals of the fungicides do not enter the tissues of the host to destroy the fungus threads among the cells.

It is evident that the prevention of the ravages of fungous diseases is a broad subject. Many ways will readily occur to one who thinks of the myriads of parasitic fungi and their varied host plants. These ways may all be grouped, however, under two general topics : namely, (I) the destruction of the parasite; (2) the prevention of its growth upon or within the host.

\section{Preventive Measures}

Taking up the latter topic first, we find that for many fungous diseases the most important method of prevention 
lies in the selection of varieties or strains of varieties that are able to resist the attacks of the parasite. In the case of the grain rusts as well as of many other diseases, this seems to be the only practical way of preventing injury. It is of the greatest importance that disease-resisting sorts be planted of all crops in which there is a variation in this ability. Crop growers should always be on the alert to discover individual plants that are able to resist the parasites. One may thus develop a strain of greatest value.

Some years ago an asparagus field in one of the central Western states was struck by the asparagus rust. In the great area of reddened plants, only one stood out green and flourishing. Through some peculiarity of its life substance it was able to resist the attacks of the fungus. The owner had the good sense to see that this plant might be made the parent of a resisting race. So he saved the seed, selected the most resistant plants that grew from them, and in a few years was able to introduce to the trade a valuable variety.

Similar progress has been made in the selection of varieties of cotton able to withstand the dreaded wilt disease for which no remedy is known.

The selection of disease-resistant plants and the breeding of new varieties from them is now occupying the attention of many painstaking men. Much progress has already been made, and we may soon expect great benefit from their labors.

Anotherimportant method of preventing the growth of the parasite upon its host is so to isolate the crop that the fungus may not reach it. In the case of many diseases, the spores of which are carried far and wide through the air, this is not practicable. Many of the rusts, for example, travel great distances on the wind, and thus reach crops 
on new ground. In the case of many other diseases, however, the fungus remains in the soil from year to year, and unless crop rotation is practiced, each succeeding season is likely to show greater damage. This is notably true of some of the smut diseases: a garden in which swect corn was grown for many years finally produced few ears that were not injured. This fact makes more plain the lesson of all good agriculture that a rotation of crops is one of the first essentials to success.

In general, good tillage and fertilization help to prevent injury by fungous diseases. Many plants seem better able to grow without damage by fungi when they are in a vigorous condition. This is not always true, however, for the very rapidity of growth in some plants produces conditions favorable to the development of the parasite. Pear trees of quick growth are much more liable to blight than those of slower growth, and grains growing vigorously seem to be more liable to injury by rusts than those of slower growth.

Sometimes it is possible to exclude the germs of the parasites by mechanical means. The various mildews and rots that affect grapes are readily excluded by fastening paper bags over the stems soon after the fruit is set.

In many instances the easiest way to prevent the spores of fungi from reaching new hosts is through the direct destruction of the fungus that produces the spores. This is obviously a practical method that may be adopted under greatly varying conditions. In general it involves clean culture and the destruction of refuse materials upon which spores may be developed. The plants of many crops may continue to produce fungus spores after the fruits are gathered, and the burning or deep burying of such plants is very desirable. In the case of species of fungi that 
alternate from one host to another the destruction of one form may prevent the development of the other. Thus, the easiest way to prevent injury by apple rust is to cut down the cedar trees on which the infecting spores develop. In the case of others, the fungus may develop on wild plants and the spores be carried to those cultivated. Thus, in fighting black knot in plum and cherry orchards it is essential that the infested wild cherry trees in the same locality be destroyed.

\section{Remedial Measures}

The use of fungicides - or substances that kill fungi has recently become the most generally adopted method of preventing these diseases. These substances are applied to the surface of the soil, stems, foliage, or fruit, where they may kill the spores present at the time and may also remain for a considerable period in condition to destroy any spores that subsequently alight.

The various salts of copper are among the most important fungicides. These are used in a great many ways, but the most important combination is that of copper sulphate, commonly called blue vitriol with lime and water. This mixture was first used in Bordeaux, France, to prevent certain grape diseases. So it is generally called the Bordeaux mixture. It is now the most widely used fungicide and is recognized as a sure preventive of many plant maladies. The usual formula is : Copper sulphate, 4 pounds; unslaked lime, 4 pounds; water, 50 gallons.

The application of Bordeaux mixture to apple trees often causes a troublesome russeting of the fruit that lessens the value of the crop. On this account, dilute lime-sulphur washes are used in its place in many orchards.

Copper sulphate is also used in simple water solution. 
For spraying dormant trees in winter or early spring, it is used at the rate of one pound dissolved in fifty gallons of water. For spraying trees in leaf it is used at the rate of two ounces dissolved in fifty gallons of water.

Carbonate of copper is also used as a fungicide. It is generally prepared as follows: Three ounces of the carbonate are to be dissolved in three pints of ammonia, the whole then being added to a barrel of water. The powdered carbonate dissolves more readily if it is first made into a paste by mixing with water. One advantage of this fungicide, which is used for the prevention of apple scab and various mildews, is that, being a clear solution, there is no clogging of nozzles, as sometimes happens with the Bordeaux mixture.

Sulphide of potassium or liver of sulphur is sometimes used to prevent the mildew on the leaves and fruit of gooseberries. Half an ounce is dissolved in two gallons of hot water, and the solution when cold is applied to bushes in the form of a spray.

Powdered sulphur, commonly called flowers of sulphur, is valuable as a fungicide for some forms of fungi affecting plants. It is used in California as a preventive of asparagus rust. The fumes that rise from the sulphur on the hot soil in sunshine kill the rust spores.

The lime-sulphur spray used as a remedy for scale insects is also a fungicide. It has proved one of the best remedies for peach-leaf curl, brown rot of stone fruits, apple scab, and other diseases.

Solutions of formalin have been found of great value as fungicides in the treatment of potato scab and grain smuts. Fortunately, this substance is now taking the place of corrosive sublimate - a poison too dangerous to use unless absolutely necessary. 


\section{Combining Insecticides and Fungicides}

In many cases it has been found that a fungicide is also of value as an insecticide, and vice versa. In others, it is easy to add an insecticide to the fungicide solution, and thus prevent both classes of injury by one application. A Bordeaux mixture with arsenate of lead added is the combination most frequently used in the past, but it seems likely to be displaced by the combination arsenate of lead and the lime-sulphur wash.

"The successful orchardist of the future," writes W, M. Scott, "will be the man who, among other things, studies the conditions existing on his own farm and sprays his trees according to the needs of each variety for the control of the particulat troubles which occur in his locality. The course of treatment best suited for the orchards of the Shenandoah Valley of Virginia may not necessarily give the best results in orchards situated east of the Blue Ridge in that state, and again the treatment for certain varieties of apples may be different from that required for certain other varieties growing in the same locality. The course of treatment should be planned not only with reference to the diseases to be controlled, but also with reference to the probable effect of the fungicide upon the fruit and foliage of the variety to be treated. The Ben Davis, for example, is so seriously russeted by applications of Bordeaux mixture that often most of the fruit sprayed with this fungicide is rendered second class. In Virginia this variety does not suffer materially from the attacks of scab, bitter rot, or other serious fruit diseases, the leaf spot which is easily controlled being its chief fungous enemy. The Ben Davis in Virginia and in other similar situations may therefore be successfully sprayed with a 
weak fungicide which will control the leaf spot, sooty fungus, and slight scab infections without injury to the fruit or foliage. The York Imperial is another variety which has no serious disease of the fruit, and in addition it is not subject to Bordeaux russet, so common on the Ben Davis, but the foliage is susceptible to leaf spot and is often badly injured by applications of Bordeaux mixture.

"On the other hand, the Yellow Newtown is seriously subject to the attacks of bitter rot and must be treated with a strong fungicide, such as Bordeaux mixture, for the control of this disease. The fruit of this variety is susceptible to Bordeaux injury, but since such injury is produced only by the early applications of the mixture, the treatment may be so planned as to avoid it. One of the lime-sulphur sprays may be used for the first and second sprayings after the petals fall, and Bordeaux mixture for the bitter rot treatments which come later. These are the finer points to be considered in connection with spraying, and the orchardist who gives them due consideration will obtain the best results in the production of good fruit."

The National Department of Agriculture issues bulletins giving precise directions for the preparation of fungicides. These are frequently revised, and should be obtained when fungicides are to be prepared.

\section{OBSERVATIONS FOR PUPILS}

I. What methods of preventing plant diseases are employed in your neighborhood?

2. Do the more progressive farmers use the spraying machine or those less progressive?

3. Read such of these references as your teacher may request :-

Spraying for Cucumber and Melon Diseases, Farmers' Bulletin 23r. Fungicides and their Use in preventing Diseases of Fruits, Farmers' Bulletin 243. Insect and Fungous Enemies of the Grape east of the Rocky Mountains, Farmers' Bulletin 284. Grape Diseases on the Pacific Coast, Farmers' Bulletin 30. 


\section{CHAPTER XXV}

\section{Fungous Diseases of Insects}

DiD you ever notice on the window pane in autumn a dead, swollen fly sticking to the glass by its tongue and feet, with a circle of white, powdery dots about it resembling a halo, and with an abdomen so swollen that it seems to be made up of alternating black and white rings? If you break the fly apart, you will probably find it brittle, and with a lens you can see whitish threads inside.

This fly is the victim of a parasitic fungus somewhat similar to many of the fungi that cause disease and death in the higher plants. The white dots are the spores of the fungus thrown out from the fruiting threads that have developed in the body. By means of these spores other living flies may catch the disease and die.

One who understands how dangerous flies are as carriers of the germs of typhoid fever and other diseases of mankind will not regret that they themselves are thus destroyed by this parasitic fungus. Consequently it is easy to acknowledge that we have friends as well as foes in the great group of fungi.

The halo-producing fly parasite is a typical example of the family of Insect-killing Fungi (Entomophthoreæ). It belongs to the genus Empusa, so called because the Greeks in ancient times used the name Empusa when they fancied they saw "a weird specter of constantly changing shape."

A parasitic fungus closely related to that which attacks the house fly often occurs in colonies of aphides or plant 
lice. During moist weather, which is especially favorable to the growth of fungous diseases of insects, this aphid parasite often destroys billions of victims, checking destructive outbreaks of crop pests. You can readily distinguish with a lens the plant lice that are killed by the fungus from those killed by insect parasites.

A similar fungus is often very helpful in checking outbreaks of the chinch bug, and has been the subject of many investigations to determine whether it can be utilized as a remedy for this insect. Dead bugs covered with the whitish, moldlike growth of the fungus may generally be found wherever chinch bugs are abundant. While probably the artificial propagation and dissemination of the bugs hastens the spread of the malady, the success of the measure is largely dependent upon the damp weather favorable to the development of the disease.

Fortunately these insect-killing fungi attack caterpillars of many kinds. A short search among cabbages will often show a cabbage worm killed by such a disease. The body of the caterpillar is filled with the fungous threads which convert it into a mummified condition, and finally produce upon the surface a crop of spores. Many other insects, especially grasshoppers, are attacked by a similar disease.

\section{Caterpillar Fungi (Ascomycetes)}

Another group of these insect parasites attacks caterpillars of many kinds, and are often called the Caterpillar Fungi. They belong to the great group of Ascospore Fungi to which so many diseases of plants belong. They are readily distinguished by the strange, clublike projection in which the ascospores are developed. Two of these mushroom-like bodies coming from a fly are shown in the picture on the next page. White grubs are often killed 
by a fungus belonging to this group, developing a curious growth that generally projects from the head.

\section{White Fly Fungi}

One of the most noted illustrations of the effect of parasitic fungi upon injurious insects is found in the case of the White Fly or Aleyrodes, various species of which are destructive to orange and other trees in the Southern and Pacific coast states. Similar species are also destructive in greenhouses in the North. At least seven distinct forms of the fungi are known to attack these insects, and many successful experiments have been made in spreading the diseases artificially. The most effective way is by washing into water the

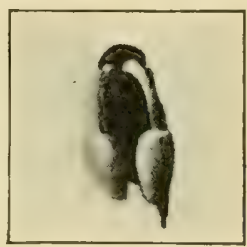

FLY IVITH

FUNGI spores that have developed on the insects killed by disease, and spraying the water on the infested plants. The Florida Experiment Station has shown that this method is easy and effective. The spraying apparatus must have no copper in it, except the nozzle, as faint traces of copper are liable to kill the spores. Another method is simply to pin leaves covered with the dead insects upon the branches of trees that are infested by White Flies. The diseaseproducing fungi are most likely to spread during wet weather.

\section{Bacterial Diseases}

The diseases of insects due to Bacteria are perhaps more important than any others. When tent caterpillars, cutworms, army worms, or various other insects become extremely abundant, they often die suddenly in great numbers, seeming to be affected by a sort of cholera that causes death and rapid decay. This is a bacterial disease. 
Not all bacterial diseases of insects, however, are helpful to man. The Foul Brood, which is so destructive to honey-bees, and the dreaded flacheric of silkworms, are both due to these microscopic germs. They cause great losses to the bee-raising and silk industries.

\section{OBSERVATIONS FOR PUPILS}

I. In autumn look for flies that show the ring of spores around them.

2. Look for diseased aphides or plant lice, especially between cabbage leaves and on clover plants.

3. Keep watch for dead grasshoppers clinging to the tops of wire fences or herbaceous plants.

4. If you live in a region where chinch bugs are found, hunt for dead, moldy specimens.

5. If you live in a region where white flies are abundant, look for those killed by fungus, and try spreading the disease.

6. When you find any of these diseased insects, place them in a glass, add a few drops of water, and cover tightly. Watch daily for the development of spores. Examine these under the microscope.

7. Read this reference: - Nature Biographies, pages 89-95.

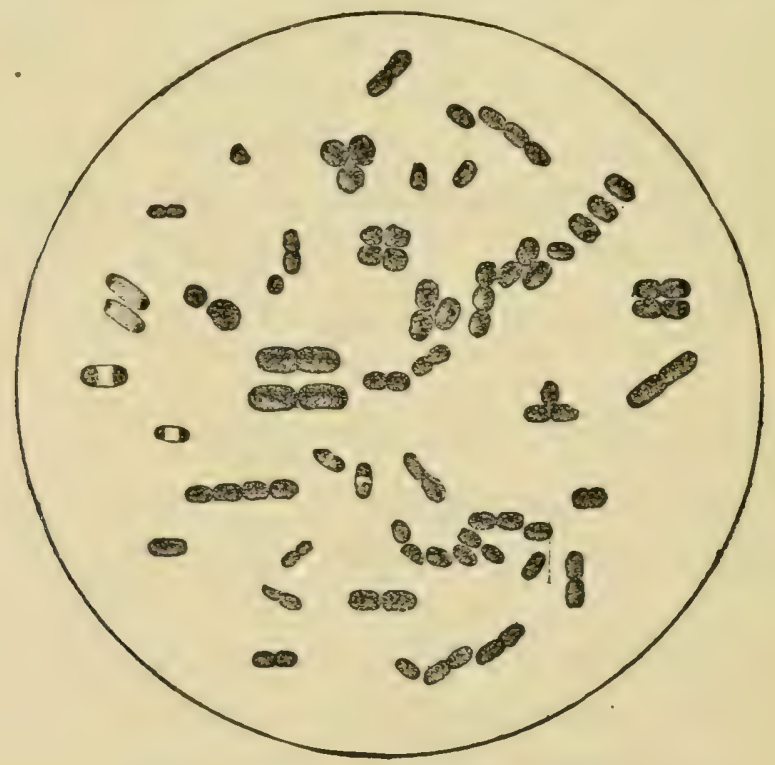

BACTERIA; HIGHLY MAGNIFIED 


\section{CHAPTER XXVI}

\section{Bacteria and Plant Food}

IT has been shown in an earlier chapter that the microscopic forms of life called microbes or bacteria often cause serjous losses on account of the blights and rots that they induce in plants. Such bacteria are true parasites, developing within the tissues of living plants and causing injury and death. It is well known that vast numbers of bacteria are similarly parasitic upon animal life, causing many of the most fatal diseases in man and the lower animals. Most of these forms of germ life must, of course, be reckoned among the farmer's foes.

\section{The Nitrifying Bacteria}

There are many other bacteria, however, that may well claim to be friendly to the farmer, for they serve an important purpose in furnishing food to his crops. One group of these is present in vast numbers in fertile soils where they help to form the nitrates which are very important in supplying food to plants. The plant or animal materials added to the soil for fertilizing purposes contain nitrogen in combination with various other elements. Consequently most of the nitrogen in the soil exists in the form of these organic compounds - that is, compounds made by organized or living things. In order that the nitrogen in these organic compounds may be utilized by growing plants, it must be recombined to form nitrates - 
that is, combinations of nitrogen, oxygen, and some element like lime or potash — which are readily absorbed through the roots of plants.

There are certain sorts of bacteria the special function of which is to convert the organic nitrogen into nitrates. These are called the Nitrifying Bacteria. During this process the organic material is first converted into an ammonia form, then into a nitrite form, and finally into the nitrate form. In a general way this is a change from a condition in which the nitrogen is insoluble into a condition in which it is readily dissolved.

During recent years the importance of this nitrifying process has received a great deal of attention. It is now recognized that good farming involves such treatment of the soil that these friendly germs may do as much work as possible, and that their abundance is an important test of soil fertility.

\section{The Nitrogen-gathering Bacteria}

In addition to the store of nitrogen in the soil which is unavailable until it is changed into the nitrate form by the nitrifying bacteria, there is an even greater store of it in the air. This supply is so great that it has been estimated that there are seventy-five million pounds of nitrogen resting upon every acre of land. This nitrogen in the air, however, cannot be used directly by plants, so that it seems to have little value as a fertilizer.

But here again the friendly germs come to the farmer's help. If you dig up a vigorous red clover plant and wash the soil carefully away from its roots, you will probably find upon the latter many small, roundish tubercles. If you treat a soy bean plant in the same way, you will find a condition like that pictured on the opposite page. And you may easily 
find similar tubercles upon the roots of beans, peas, vetches, sweet clover, alfalfa, and various other members of the great family of legumes, or pod bearers.

It took a long while for man to trace the connection between these tubercles upon the roots of the pod-bearing plants and the free nitrogen of the air. There is still much mystery about it, but we now know that the tubercles or nodules are composed chiefly of colonies of bacteria, and that these bacteria are able to convert the free nitrogen in the air between the soil particles into a form that is utilized by the plants. They may well be called the Nitrogengathoring Bacteria, and are to be classed among the farmer's best friends.

We have seen that some bacteria may live as parasites upon living plants or animals: these are the Parasitic Bacteria. We have also seen that some bacteria including the nitrifying forms may liveas saprophytes upon dead

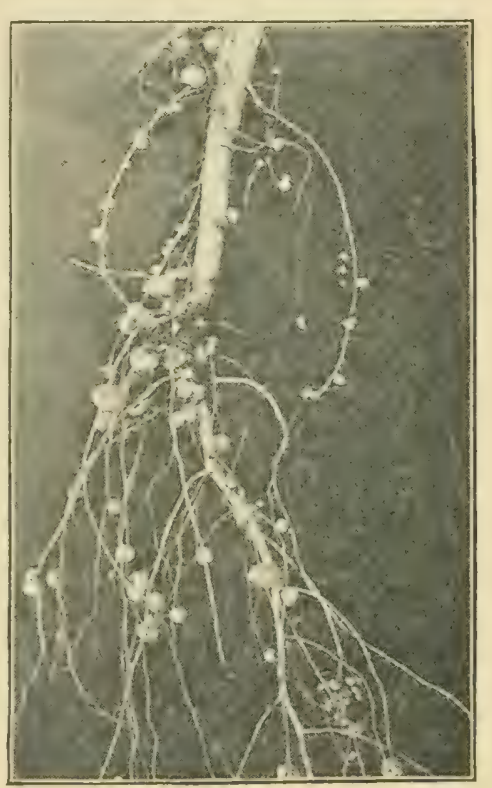

ROOT OF SOY BEAN SHOWING TUBERCLES and decaying plants or animals: these are the Saproplytic Bactiria. We have now to determine the relation of the nitrogen-gathering bacteria to the leguminous plants. Evidently they are not parasites, for they help rather than injure the growth of the plant. Nor are they saprophytes, for they develop upon living rather than dead plants. They seem to form a sort of partnership with the plants. They need a home to grow in and some help to get their growth; in return they gather nitrogen for the benefit of their hosts. 
When we speak of two plants thus living together in mutual helpfulness, we use the word symbiosis: so we say that the nitrogen-gathering germs are Symbiotic Bacteria.

These symbiotic bacteria are of great importance to practical agriculture. In most good systems of crop rotation, clover or some other leguminous plant is grown every few years in order that the supply of available nitrogen in the soil may be increased. Clover is able to increase this supply because of the help given by the germs living in the nodules on the clover roots. One of the best ways to improve poor soil is to grow a leguminous crop and plow it under as green manure. The value of this process lies largely in the presence of the nitrogen-gathering bacteria. When an alfalfa field is well established, it may be left undisturbed except for harvesting the crops, for many years. Presumably it is able thus to yield its forage year after year because the bacteria in the nodules on the roots are gathering free nitrogen from the air.

A striking example of the effectiveness of these bacteria in gathering nitrogen has been recorded by the Illinois Experiment Station. Three sets of ten cowpea plants with tubercles on the roots were analyzed to determine the percentage of nitrogen. Three other sets of ten cowpea plants without tubercles were also analyzed for comparison. "The infected plants contained nearly four times as much nitrogen as the plants not infected, and about three fourths of the total nitrogen in the infected plants was obtained from the air. The roots and tubercles of the infected plants contained six to seven times as much nitrogen as the roots of the plants not infected."

It is an interesting fact that the bacteria found in nodules on the roots of red clover will not develop upon the roots of cowpeas or several other related plants. Similarly, the 
bacteria from cowpeas will not develop upon red clover. Thus in a broad way we may say that each distinct legumi-

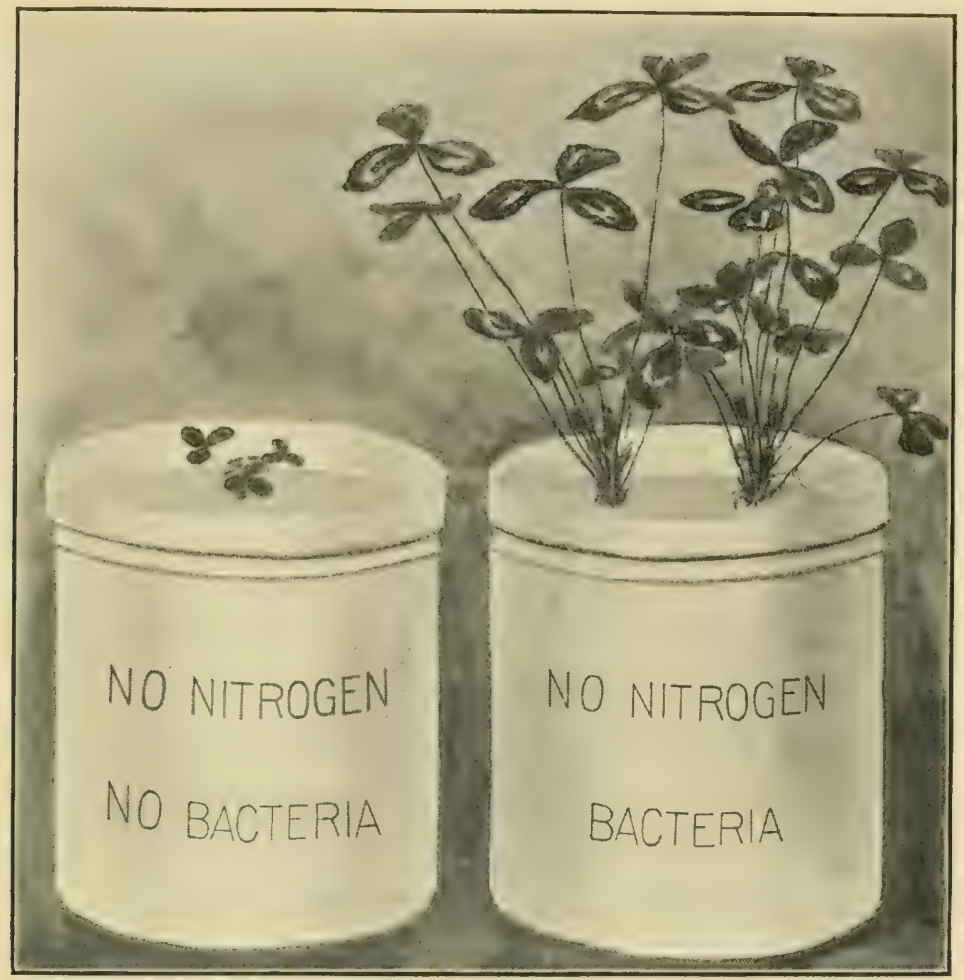

RED Clover : EFFECT OF BACTERIA

nous crop has a special form of symbiotic microbe and that, as a rule, these microbes are not interchangeable.

\section{DECAY OF NODULES}

Another important fact is that most of these bacteria are unable to live independently in the soil more than five or six years after the crop on which they develop has disappeared. Consequently we cannot expect to find in a given soil the various germs waiting to develop upon any leguminous crop that may be planted. Nor in most cases is it safe to assume that enough of these germs will adhere 
to the seed and be planted with them to insure a good development of tubercles upon the roots.

Consequently, the conditions that exist in a given case may be something like this: Here is a field in which no red clover has been grown in a dozen years. The soil is poor and sour. It produces very small crops and evidently needs to be improved. We wish to grow red clover to help its condition. Evidently we must get rid of the sourness by a liberal application of lime or some other alkaline fertilizer. Then we must introduce the clover tubercle germs into the soil and sow the seed. Such introduction of germs is often spoken of as inoculation - that is, we inoculate the soil with the desired microbes in the expectation that when introduced they will thrive and multiply upon the clover roots. One of the simplest ways of inoculating is to bring a quantity of soil from a field in which clover has been growing successfully. Being sure that the plants grown in the soil have shown plenty of nodules, spread it broadcast and harrow it in. We may thus get a very general dispersal of the germs where they will come in contact with the dereloping clover roots.

Another way to inoculate the soil is to shake up in a bottle of water a small quantity of soil from a thriving clover field. Let it stand until the soil particles settle, and pour the clear liquid over the clover seed or upon the soil where the seed is planted. This method is especially useful in pot experiments.

Fortunately, these nitrogen-gathering bacteria can be induced to develop in vast numbers in what are called nutrient solutions. The scientists of the United States Department of Agriculture have been at work for many years upon the methods of growing bacteria in such solutions. They have succeeded so well that the Department 
now offers to the public small culture tubes of the microbes of each of the important leguminous crops, with precise directions for their use. This enables any one to inoculate his soil for any crop desired.

Experience has shown that with some crops at least it is worth while at first to grow the same crop for two successive seasons in order to secure a thorough inoculation of the soil. After that, if the crop is grown in rotation every four or five years, the microbes are likely to continue present in such numbers that further inoculation is unnecessary.

The germs that grow upon cowpeas seem very generally present in the soil of the Southern states. Consequently it is seldom necessary to inoculate for this crop.

The germs that grow upon sweet clover or melilot seem to be able to develop with equal vigor upon alfalfa. Consequently, it is often practicable to inoculate alfalfa fields with soil in which sweet clover has been growing.

\section{OBSERVATIONS FOR PUPILS}

I. Make a list of the leguminous plants in your locality upon which you find root tubercles.

2. Compare the abundance of the tubercles with the vigor of the plant.

3. Grow red clover in sand or other soil deficient in nitrogen, being sure it is from a field where red clover has not grown. Apply the germs obtained as suggested on page $2 \mathrm{j}^{\circ}$, to part of the pots, but not to all. See which set grows best, making sketches every two weeks.

4. Read such of these references as your teacher directs :-

Leguminous Crops for Green Manuring, Farmers' Bulletin 278. Progress in Legume Inoculation, Farmers' Bulletin 315. The Renovation of Worn-out Soils, Farmers' Bulletin 245. Alfalfa, Farmers' Bulletin 339. Clover Farming on the Sandy Jack-pine Lands of the North, Farmers' Bulletin 323. Canadian Field Peas, Farmers' Bulletin 224. Cowpeas, Farmers' Bulletin 318. The Liming of Soils, Farmers' Bulletin 77. 



\section{PART IV}

FRIENDS AND FOES AMONG THE BIRDS 


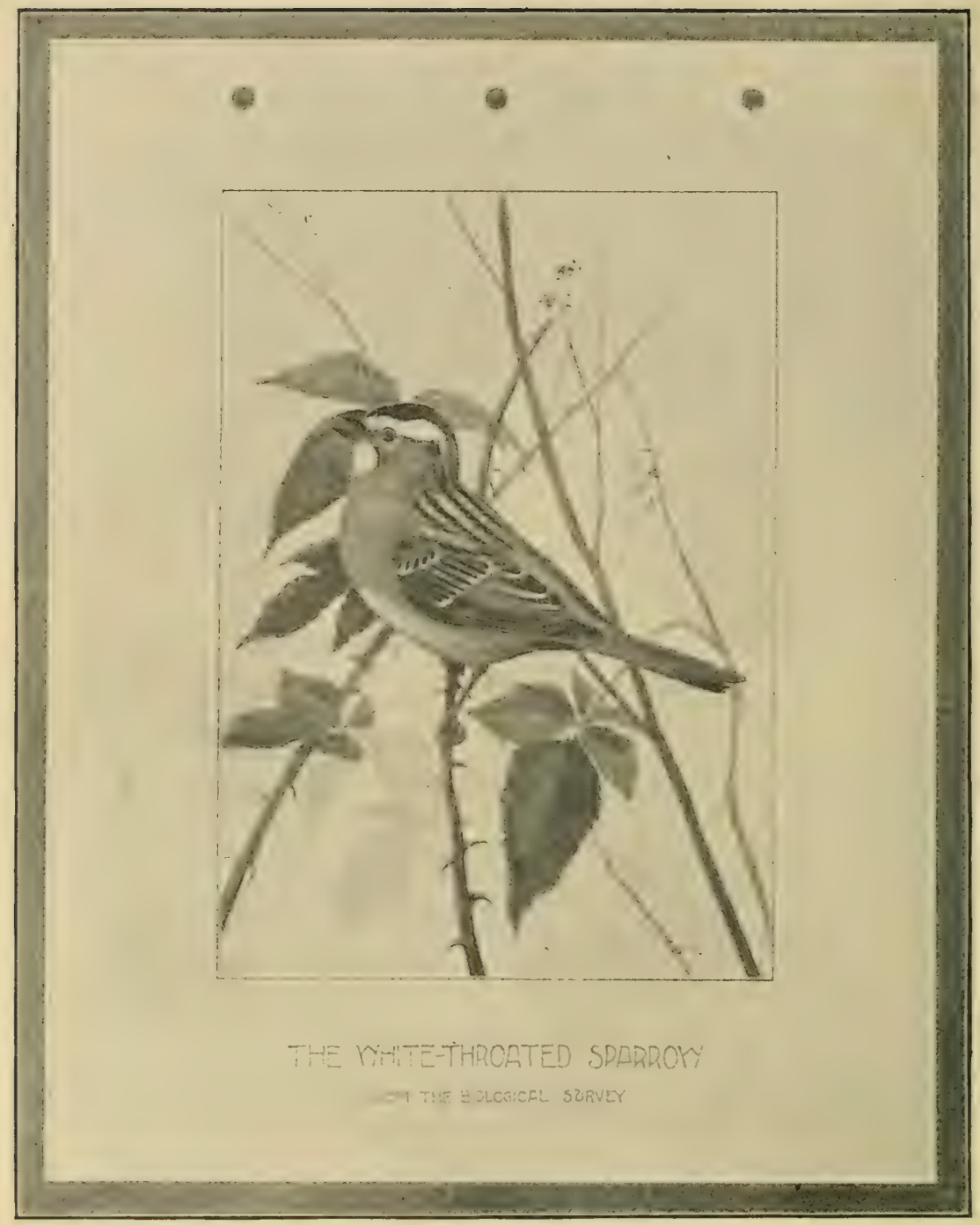

A PAGE FROM A BIRD BOOKLET

\section{THE BOOKLET ON BiRDS}

Birds are more difficult to draw than plants or insects. Consequently this booklet is likely to have fewer pages of drawings of the birds themselves, though these may readily be replaced by drawings of fruits, seeds, and insects which are eaten by birds, as well as by mounted pictures cut from magazines.

Abundant opportunities for written or printed pages may be found in the suggestions at the ends of the chapters on birds. Delightful poems concerning birds are readily found and may be copied for the booklet. 


\section{CHAPTER XXVII}

\section{The Relations of Birds to Fruit Orchards}

In a large part of North America the apple is the leading orchard fruit. The pear and the peach are much less generally grown, although each is important in certain localities. The same is true of cherries, plums, and quinces, though in the aggregate each of these fruits is of great value.

These orchard trees are subject to attack by a great variety of insect enemies. Root, trunk, branch, twig, leaf, and fruit - each part has special enemies that too often blight the crop. Fortunately, however, most of these enemies are largely held in check by various birds that frequent the orchards and help to keep a balance that is favorable to fruit production. Where birds are scarce the task of fruitraising is greatly increased.

\section{Trunk, Roots, AND BRAnches}

The trunk and the larger roots and branches of most fruit trees are subject to attack by a great variety of burrowing insects. In general, the eggs are laid on or in the bark by a winged beetle or moth. These eggs hatch into larvæ that burrow in bark, sapwood, or heartwood, remaining at work until full grown as larvæ. They then change to pupx, generally in or near the outer bark, and emerge later as adult beetles or moths.

Common examples of such destructive insects are found in the round-headed apple-tree borer, the flat-headed borer, 
the peach-tree borer, the fruit-bark beetle, and the sinuate pear borer.

Set over against these enemies of trunk and branch, we find the woodpeckers, nuthatches, creepers, and chickadees. These birds are constantly searching the bark for the larva and pupx concealed within, and they are wonderfully adapied both to discover the position of the pests and to dig them out. The long, barbed tongue of the woodpecker can be thrust into the hole made by a borer and draw the larva quickly forth. The larger and more deeply embedded larvæe are especially sought by the woodpeckers, while the smaller insects on or near the surface are eaten by the nuthatches, creepers, and chickadees.

The twigs or smaller branches of fruit trees are attacked by a great variety of insect enemies. The sap is sucked through the bark by hosts of scale insects or bark lice, and aphides or plant lice, as well as by tree hoppers and related pests. Many of the birds already mentioned feed freely upon these various insects, the nuthatches, creepers, and chickadees being especially useful in this respect. These are not alone, however, in the good work. They are assisted by the orioles, sparrows, vireos, warblers, grosbeaks, wrens, gnat catchers, bluebirds, and other feathered friends. In the case of the scale insects alone, fifty-seven kinds of birds have been listed as feeding on them.

\section{Buds AND Leaves}

When we consider the relations of birds to the enemies of the buds and leaves of orchard trees, we find so close a connection that we are forced to conclude that the life of the trees depends upon the birds. Tree leaves are beset by a bewildering host of insect enemies. Aphides, scale in- 
sects, leaf hoppers, and many other true bugs suck out the sap; leaf miners of many sorts mine the leaves; while beetles, grasshoppers, crickets, and numberless caterpillars devour the blades.

Set over against these myriads of leaf-feeding insects, we find the great majority of our familiar birds. Watch the birds in an orchard on a summer day and you will be convinced of their great value as insect destroyers. If you are keen-eyed and patient, you will see the warblers and other smaller birds searching leaf after leaf for aphides and tiny caterpillars, while vireos, bluebirds, robins, thrushes, sparrows, cedar birds, cuckoos, catbirds, blackbirds, and others are devouring the larger enemies. If you watch these birds at their nests, you will see that the young are fed with vast numbers of such insect foes. Even in winter the eggs and pupæ are con-

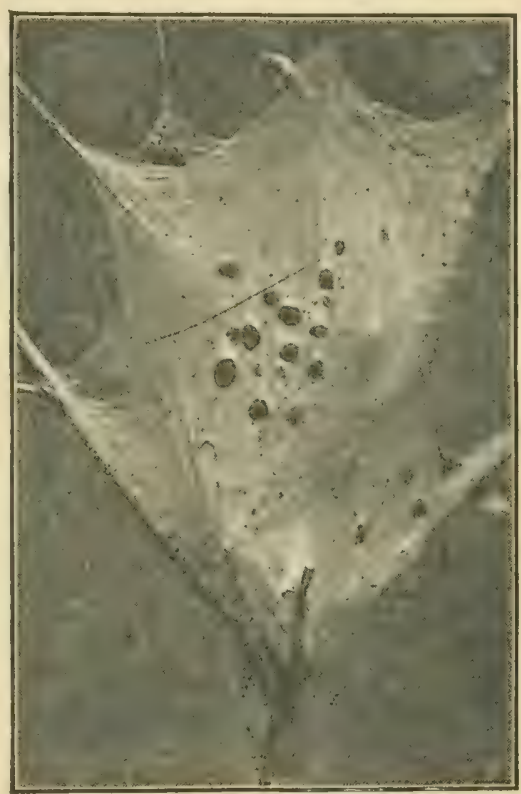

TENT-CATERPILLAR NEST ATTACKED BY BIRDS tinually eaten by birds.

The enemies of the fruits of orchard trees are less numerous than those of the leaves, but still their name is legion. Scale insects, beetles, bugs, caterpillars, maggots, midges, and other pests all attack one kind of fruit or another, often destroying the bulk of the crop. The birds that attack these enemies are nearly as numerous as those that attack leaf-feeding insects, and the good they do is incalculable. 
What is true of the relations between insects and birds in orchards of deciduous fruits is equally true in orchards of citrous fruits. Wherever oranges, lemons, and related trees are grown for profit, hosts of insect enemies attack the trees. These insects are preyed upon by birds which help greatly in checking the injuries of the pests.

\section{A ËRIAL INSECTS}

Nearly all the insects that affect orchards exist part of their lives in a winged condition in which they fly through the air from branch to branch or from tree to tree. At such times they are in danger of being snapped up by flycatchers, vireos, swallows, and other birds. Most of these keep watch over comparatively limited spaces near the trees, but the whole realm of the air is patrolled by the swallows. Over the water or above the land the flying insect is in danger of being suddenly captured in the swallow's beak. The food of swallows consists chiefly of insects thus caught upon the wing; beetles, flies, ants, and small moths are all taken in great numbers. Consequently, these birds are as useful as they are beautiful, and should be encouraged by every one.

At night, also, the war against flying insects is kept up by the whippoorwills and nighthawks. These interesting birds patrol the air in dusk and darkness, catching flying insects of many kinds in their capacious jaws.

\section{Other Enemies}

There are other enemies of orchard trees besides the insects. The trunks are frequently girdled by meadow mice and rabbits that gnaw the bark. This generally happens in winter, when the mice work beneath the surface of the 
snow. Fortunately, however, hawks, owls, and other large birds feed freely upon these pests and commonly keep their numbers so reduced that little damage is done. But in regions where the hawks and owls are ruthlessly persecuted, the mice and other rodents become destructive, and often cause the loss of valuable trees.

It would perhaps be too much to expect that birds should do no harm in orchards to offset the immense good they do. In certain ways they doubtless cause damage, but this is on the whole vastly less than the benefit they confer. Some birds eat fruit, especially cherries, to a serious extent. It is indeed probably true that in fruitgrowing regions there are often more robins than are beneficial to horticulture.

Birds also cause the spread of scale insects and probably of fungous diseases, although little real injury is done in these ways. At least one bird - the true sapsuckersometimes injures the trees by boring holes in the bark and taking the sap, though this should not lead to the killing of the beneficial woodpeckers, which the sapsucker resembles.

The chief damage done to fruit by birds generally results from the extraordinary abundance of one kind of bird. Thus, in the eastern region of the United States the robin is often troublesome because it occurs in great numbers and attacks cherries and small fruits. On the Pacific coast it is sometimes very destructive in olive orchards. In the latter region birds are more injurious to fruit than in the East, partly because of the scarcity of wild fruits. The house-finch or linnet, the Brewer blackbird, the blackheaded grosbeak, and the California jay often become serious pests, although each of these doubtless does considerable good in other ways. 


\section{OBSERVATIONS FOR PUPILS}

\section{Birds in APPLE ORCHARdS}

A

I. Make a list of the birds you have seen searching the bark of the trunk and larger branches of apple trees.

2. What birds occur on apple trees in winter?

3. What birds have the habit of snapping up insects in the air?

4. Make a list of all the different birds that you can find in apple orchards.

$$
B
$$

I. Write a little story with this title: The Birds in Our Orchard. Simply tell what you have seen.

2. Read as many of these references as you have access to :-

Birds in their Relation to Man, pages I-8, 68-80, 304-315. Useful Birds and - their Protection, pages I49-I54. IIow Birds Aftect the Orchard. Yearbook Reprint 197. I)oes it Pay the Farmer to Protect the Birds? Yearlook Reprint $4+3$. The Relations between Birds and Insects, Yearbook Reprint 486. 


\section{CHAPTER XXVIII}

\section{The Relations of Birds to Meadows and Pastures}

While the insects that affect the grasses of meadow and pasture lands are by no means so numerous as in the case of the orchards, there are enough to prove seriously destructive at times. If this is true with the constant check the birds keep upon them, there is little doubt that they would do vastly greater damage were there no birds.

The various forms of locusts or grasshoppers with short antenna are among the most abundant of meadow and pasture pests. They are nearly always present in sufficient numbers to do some damage, and often become so abundant as to destroy the growing crop. The meadow grasshoppers with long antennæ. are often abundant enough to do some injury. The much smaller leaf hoppers are also nearly always present and do much more damage than is generally supposed. Many sorts of cutworms, including the notorious army worm, are always feeding on the blades of grass near the ground, and other kinds of caterpillars are continually at work.

In addition to these enemies of the stems and blades, the roots of grasses are attacked by many pests. The voracious white grubs - the larvæ of the familiar May beetles; the slender yellow wireworms - the larvæ of the common click beetles; the curious meadow

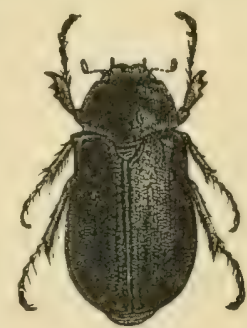

May BeEtle maggots - the larvæ of the long-legged crane flies, - these and many other pests feed upon the roots of grasses. 
The clovers and other forage crops often grown in meadows have their special insect enemies that furnish food for many birds.

The variety of bird life that is found in grasslands is also much smaller than in the case of orchards. Comparatively few species have adlapted themselves to live upon
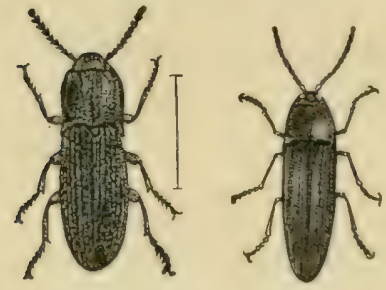

CIICK BEETLES the ground in grasses, but these few are of immense benefit as destroyers of insect pests.

The most notable meadow and pasture birds are these: the meadow lark, the crow, the various blackbirds, the bobolink, the cowbirds, the ground sparrows, and the robin. While these do not all live exclusively on the ground in grasslands, they find there an important part of their yearly food supply.

The Meadow Lark is a typical example of these birds. It is an abundant and widely distributed species, living habitually in grasslands and finding there practically all its food. Originally a native of the great prairie regions, it has gradually spread as forests have been replaced by fields and meadows until it is now found over practically the whole of the United States.

The food of the Meadow Lark has been carefully studied by many competent investigators. In Illinois Professor Forbes found that at least three quarters of the food during the spring and summer consisted of insects. Cutworms, army worms, and other caterpillars formed more than a quarter of the food supply, while various beetles formed a fifth and grasshoppers more than an eighth. The beetles eaten included June beetles, blister beetles, curculios, click beetles, and plant beetles. Twenty chinch bugs 
had been eaten by one bird, and others had devoured crane flies.

Studies in other places show similar results and bring out the fact that in autumn when insects become more scarce the Meadow Lark feeds freely upon the seeds of weedy plants. It consequently is of great value wherever it is found, and should be given the most careful protection.

The Bobolink is one of the most delightful of meadow birds. It is also one of the most useful, for it feeds freely on grasshoppers, caterpillars, and other insect pests as well as on the seeds of weedy plants. In the North it is eminently beneficial, though on its way southward it often becomes a pest in rice fields.

While it cannot fairly be claimed that the Crow and the various

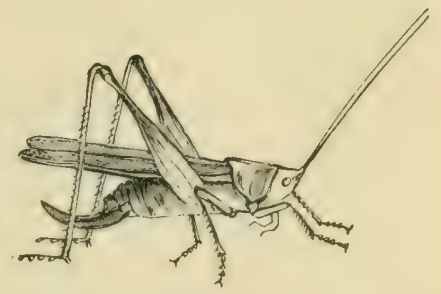

MEADOW Grasshopper Blackbirds are entirely beneficial, there is no doubt that they do much good to offset some harm. So far as their actions concern meadows and pastures, these birds are of benefit, for they devour vast numbers of grasshoppers, cutworms, army worms, white grubs, June beetles, and other pests. The harm they do is chiefly in grain fields, either at the time of planting or that of harvesting.

There are several kinds of Sparrows that live more or less on the ground in pastures and meadows. The more important are these: the Field Sparrow, Song Sparrow, Vesper Sparrow, Savanna Sparrow, and the Dickcissel. All of these birds feed freely upon grass insects, destroying vast numbers of crickets, grasshoppers, cutworms, and other caterpillars, as well as the seeds of weedy plants. The young are also fed with similar insects, so that these birds are eminently beneficial. 
The presence of flocks of Robins scarching grasslands for food is one of the characteristic sights of early spring. At no other season, perhaps, do these birds search so persistently upon the ground. A large proportion of the grasshoppers, cutworms, army worms, and other grass insects that have succeeded in living through the winter

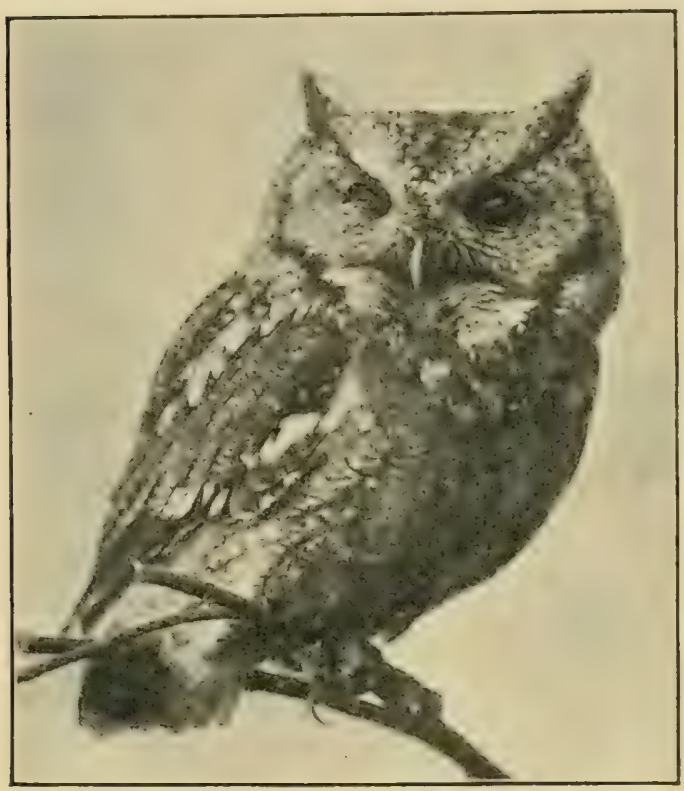

SCREECH OWL are then eaten by the Robins. This early spring destruction of such pests is of great value in checking their increase, and the birds atone for many sins in the cherry trees by their actions at this season.

No consideration of the relations of birds to insects of grasslands would be adequate that did not take account of the flycatchers, swallows, swifts, whippoorwills, and nighthawks, a large part of whose food consists of grasshoppers, leaf hoppers, beetles, moths, and other pests of grasslands.

As their name indicates, the meadow mice are often very destructive in pastures and meadows. They destroy much grass by feeding upon crowns or roots, and their runways in spring often show how busy they have been beneath the snow in winter. The hawks and owls are the most important natural checks upon these pests. The experiences of many regions show that where these birds are 
relentlessly persecuted, the meadow mice are likely soon to multiply to an alarming extent, sometimes destroying the crops in whole fields.

\section{OBSERVATIONS FOR PUPILS}

Birds in Meadows and Pastures

I. Make a list of the most important grass-feeding insects in your locality.

2. Make a list of the birds you have seen upon the ground in pastures or meadows, or both.

3. Make a list of the bircls that build their nests on the ground in pastures and meadows.

4. Read as many of the following references as are accessible :-

Farmers' Bulletin 54, pages 15-28. The Bird Book, pages 248-253. Birds in their Relations to Man, pages 137-144, 158-171. Useful Birds and their Protection, pages 76-80, 310-333. 


\section{CHAPTER XXIX}

\section{The Relations of Birds to Gardens and Fields}

THE conditions in regard to the crops and insects of gardens and cultivated fields vary in different regions. Consequently, it seems best to indicate the relations of birds to them by considering a few of the more widely distributed species that live chiefly in such situations.

\section{SPARROWS}

The little Chipping Sparrow is one of the most abundant of the smaller birds found in gardens and fields near houses. In the North it arrives early in spring and remains till late in autumn. Its food consists of insects and the seeds of grasses and weeds. Nearly half of the food often consists of the seeds of such noxious plants as pigeon grass and crab grass. Cutworms, cankerworms, bugs, moths, ants, beetles, and grasshoppers are among the insects caten by both young and adults. In consequence of such feeding habits, this familiar little bird is very useful and should be encouraged in every way possible.

On account of its attractive voice the Song Sparrow is perhaps an even greater favorite than the Chipping Sparrow. It is found everywhere in fields and gardens, keeping close to the ground where insects and weed seeds are abundant. It remains through the winter as far north as Massachusetts.

The other native ground-loving sparrows-- such as the Field Sparrow, the Savanna Sparrow, the Vesper Sparrow, 296 
and the Junco-have similar feeding habits. They are especially useful as destroyers of the seeds of weeds. In this respect, however, they are probably surpassed by the related sparrows that do not live so much upon the ground. These include the Tree Sparrow, the Goldfinch, the Whitecrowned Sparrow, the White-throated Sparrow, and the Snowflake. These are preëminently seed eaters, and they undoubiedly destroy thousands of tons of weed seeds every year.

The bird commonly known as the English Sparrow was brought into America from Europe in 1850 and again three years later. These birds were imported because it was thought that they would assist in the suppression of the cankerworm, an insect very destructive to the leaves of shade trees. After their introduction they thrived and spread rapidly, being carried by man from city to city so that before many years they were very generally distributed.

English sparrows are by preference city birds; they utilize all sorts of crevices about buildings for nesting and roosting purposes, and live upon a great variety of food. From towns they gradually disperse through the surrounding country, congregating about farm buildings. They breed rapidly, and have few enemies. When well fed, they can stand very cold weather without injury.

As a destroyer of noxious insects, this sparrow has been generally, though not always, a failure. There are also many misdemeanors charged to him. It is known that he habitually destroys the buds and blossoms of trees, and attacks ripening fruit of many kinds, as well as peas on the vines and seeds in the soil. Grains in the field are also devoured by the sparrows; houses are made filthy by their presence; and native birds are driven away by them. 
With these and other charges the sparrows stand indicted; and they have comparatively little good to counterbalance the evil. Consequently, it would seem that they should not be encouraged near farm buildings.

\section{Bluebirds, Robins, and Catbirds}

Next to the sparrow, the Bluebird is one of the most abundant species found in gardens and cultivated fields. Fortunately, this universal favorite is as useful as it is beautiful. Its food has been most carefully studied by Professor S. A. Forbes, who writes: "One hundred bluebirds at thirty insects each a day would eat in eight months about 730,000 insects. If this number of birds were destroyed, the result would be the preservation on the area supervised by them of about 70,000 moths and caterpillars (many of them cutworms), I 2,000 leaf hoppers, I0,000 curculios, and 65,000 crickets, locusts, and grasshoppers. How this frightful horde of marauders would busy itself if left unmolested no one can doubt. It would eat grass and clover and corn and cabbage, inflicting an immense injury itself and leaving a progeny that would multiply that injury indefinitely."

The Robin is very useful in destroying insects that live on or in the ground. It feeds freely upon such pests as cutworms, white grubs, and grasshoppers. It is especially busy in meadows when it first arrives in early spring.

The food of the Robin as determined by the investigations of the United States Department of Agriculture has been summarized as follows: "An examination of 300 stomachs shows that over 42 per cent of its food is animal matter, principally insects, while the remainder is made up largely of small fruits or berries. Over 19 per cent 
consists of beetles, about one third of which are useful ground beetles, taken mostly in spring and fall when other insects are scarce. Grasshoppers make up about one tenth of the whole food, but in August comprise over 30 per cent. Caterpillars form about 6 per cent, while the rest of the animal food, about 7 per cent, is made up of various insects, with a few spiders, snails, and angle worms. All the grasshoppers, caterpillars, and bugs, with a large part of the beetles, are injurious, and it is safe to say that noxious insects comprise more than one third of the robin's food. Vegetable food forms nearly 58 per cent of the stomach contents, over 47 being wild fruits, and only a little more than 4 per cent being possibly cultivated varieties. Cultivated fruit amounting to about 25 per cent was found in the stomachs in June and July, but only a trifle in August. Wild fruit, on the contrary, is eaten in every month, and constitutes a staple food during half the year. No less than $4 \mathrm{I}$ species were identified in the stomachs; of these, the most important were four species of dogwood, three of wild cherries, three of wild grapes, four of greenbrier, two of holly, two of elder; and cranberries, huckleberries, blueberries, barberries, service berries, hackberries, and persimmons, with four species of sumac, and various seeds not strictly fruit."

There is no doubt that the Robin is a very useful bird, when we consider its life through the year. But it is also true that at times, especially in fruit-growing regions, it is decidedly injurious.

No country boy needs to be introduced to the Catbird. It is familiar to every one who has wandered along a roadside or by the margin of woods. It is a useful bird, although it sometimes helps itself too freely to the fruits of the orchard and garden. "Ants, beetles, caterpillars, 
and grasshoppers constitute three fourths of the animal food," writes Professor Beal, "the remainder being made up of bugs, miscellaneous insects, and spiders. One third of the vegetable food consists of cultivated fruits or those which may be cultivated, such as strawberries, raspberries, and blackberries; but while we debit the bird with the whole of this, it is probable - and in the eastern and well-wooded part of the country almost certain - that a large part was obtained from wild vines. The rest of the vegetable matter is mostly wild fruit, such as cherries, greenbrier, spice berries, black alder, sumac, and poison ivy." About half of the food of the Catbird is of animal and half of vegetable nature. Planting wild fruits in outof-the-way corners is recommended to keep these birds away from the fruit garden.

\section{Blackbirds And CROWs}

Two kinds of Blackbirds are generally to be found in the Northern states. The larger of these is the Crow Blackbird, of which there are two forms - the Bronzed Grackle and the Purple Grackle, large and handsome birds, familiar to country boys throughout their range. Their food consists of insects, grains, and other vegetable matter, insects forming about one third of the total. These birds are frequently destructive to ripening wheat or other grain crops, and no doubt often do as much harm as good. But in general they should not be molested except when causing damage.

The Redwinged Blackbird is smaller than the Grackles, although in regions favorable for its breeding it is likely to be much more abundant. It builds its nest in low bushes on the borders of swamps; and in the West often appears 
in enormous flocks in grain fields, doing much damage. But its injuries are partly atoned for by the fact that it eats large numbers of injurious insects, many of them being grain-destroying pests.

In the Pacific coast region the Brewer Blackbird is abundant. Its friends have to confess that it is fond of cherries, but they also claim that it is a great destroyer of insects. When Professor F. E. L. Beal was studying these birds as they were eating fruit in a California cherry orchard, a neighboring fruit grower began plowing. "Almost immediately every blackbird in the vicinity was upon the newly opened ground, and many followed within a few feet of the plowman's heels in their eagerness to get every grub or other insect turned out by the plow."

There is a great difference of opinion about the economic relations of the common crow - a bird that is abundant over most of the United States. Many people accuse it, and with justice, of pulling up sprouting corn, robbing birds' nests, and carrying off young chickens as well as of eating small wild animals - such as toads, frogs, and snakes - which are beneficial to man. To counterbalance these sins, however, it is certain that the crow destroys large numbers of noxious insects. It also feeds freely upon various wild berries and fruits, including the sumac, dogwood, sour gum, and poison ivy.

The chief injury to corn is clone by the birds pulling up the young plants or feeding upon the swollen kernels after they become softened by the moisture of the soil.

\section{Fiycatchers, Swifts, and Swallows}

A distinct phase of the war against insect pests is carried on by Flycatchers such as the Phobe and the King- 
bird. These perch upon fences, trees, tall weeds, or posts wherever they can watch the surrounding air space. When a fly, moth, beetle or other insect comes near, the bird sallies forth and snaps it in its beak. In this way they get nearly all their food.

In the case of the Phobe more than nine tenths of the food consists of insects and spiders, chiefly those caught in the air. In the case of the Kingbird the proportion is almost as great. To a less extent the Bluebird and the Cedar Bird have similar fly-catching habits.

The greater spaces of the air over gardens and cultivated fields are patrolled during the day by the Swifts and Swallows and during the night by the Whippoorwills and Nighthawks. All of these spend hours upon the wing, continually catching the myriads of winged insects that fly from place to place. The service thus rendered is of incalculable value, and every one should strive to protect these feathered friends from enemies of every sort.

It is commonly believed that the Hawks and Owls are enemies of the farmer, to be destroyed whenever possible. But the careful studies and observations of many competent observers show that a majority of these birds are friends whose presence we could scarcely afford to lose. They destroy great numbers of mice and insects, and in Europe are recognized as beneficial birds.

The Marsh Hawk is one of the most useful birds of prey, and deserves man's protection. "Its food," writes Dr. A. K. Fisher, "consists largely of small rodents, such as meadow mice, half-grown squirrels, rabbits, and ground squirrels." The stomach of a New Hampshire specimen that I examined was full of grasshoppers.

The Sparrow Hawk is a small species that feeds almost wholly upon insects, chiefly grasshoppers, when these can 
be obtained. In the sparse pine woods of southern Florida I have found the Sparrow Hawk one of the commonest winter birds. One of its favorite methods of obtaining food there is to perch in trees on the outskirts of the forest fires that frequently occur, and catch the grasshoppers, lizards, and other animals driven from cover by the flames.

\section{OBSERVATIONS FOR PUPILS}

\section{Birds in Gardens and Fields}

\section{$A$}

I. Write a short account of birds that you have found in the yard and garden about your house. Tell what kinds you have seen and what you have observed them eating.

2. If the English Sparrow is found near your home, write a special essay about it. Tell whether it drives away other birds, what it feeds upon, where the nest is made, and how many broods there are each season.

\section{$B$}

I. Write a short essay with this title: My Favorite Bird.

2. Illustrate your booklet with such drawings as you can make, and if you have bird pictures in magazines or papers that can be cut out, paste them in also.

3. Look up the discussions of the field and garden birds you are most interested in as found in these references:-

The English Sparrow, Farmers' Bulletin 383. The Meadow Lark and Baltimore Oriole, Yearbook Reprint 37, Part 2. The Food of Nestling Birds, Yearbook Reprint 194. Birds in their Relations to Man, pages I56-I73. 



\section{PART V}

\section{FRIENDS AND FOES AMONG THE MAMMALS}




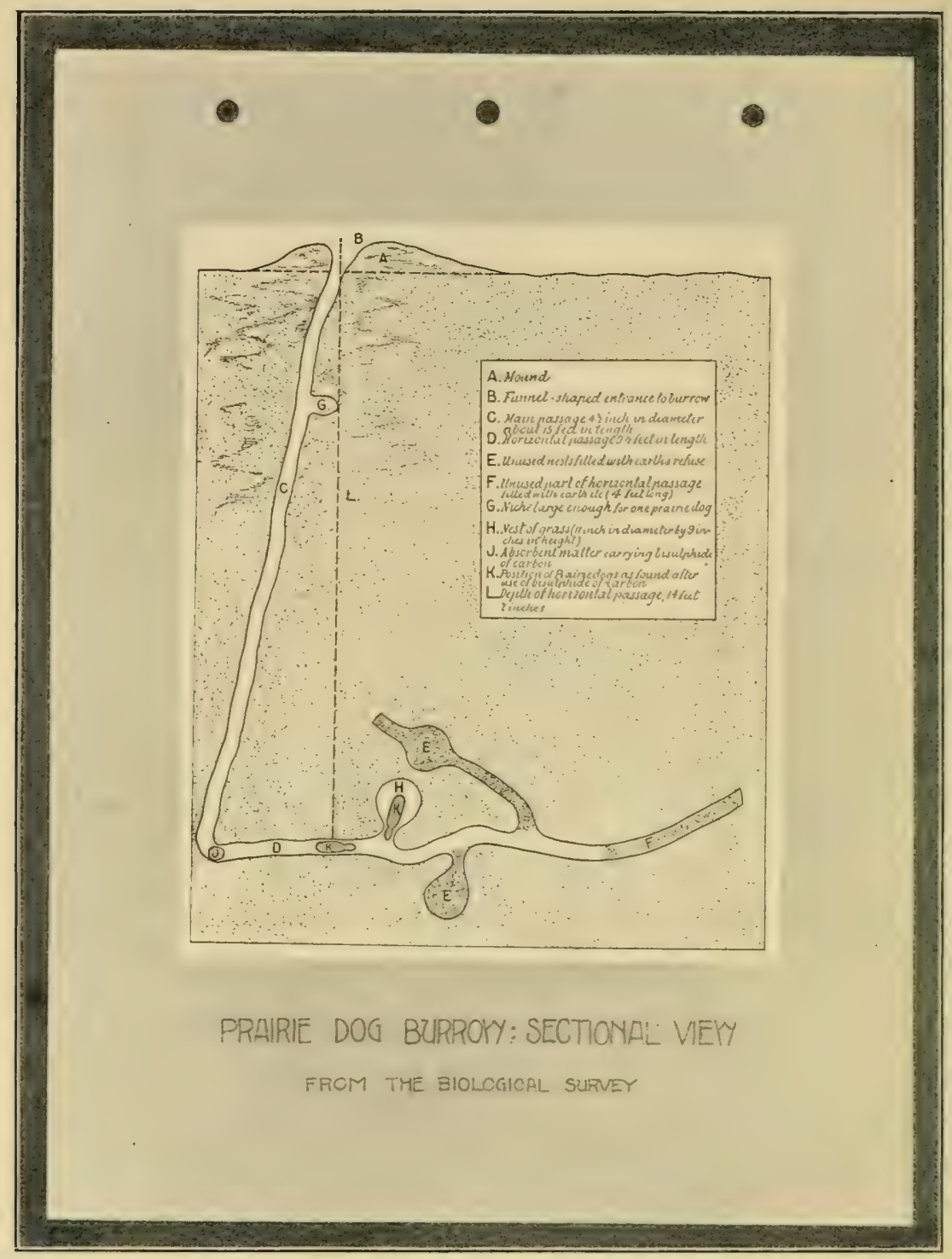

\section{The Booklet on Mammals}

It will probably be more difficult to get abundant material for this booklet than any other. It is consequently less essential that one should be made.

The booklet may well be made up largely of the observations and experiences of each pupil concerning the mammals most abundant in the locality of the school. It may readily be enriched by the use of pictures cut from magazines and mounted upon sheets of drawing paper. 


\section{CHAPTER $\cdot \mathrm{XXX}$}

\section{The Squirrels}

THE four-footed animals help to form a group called the Mammals. Some of the wild mammals are helpful on the farm, but many more are hurtful. The great majority of the latter belong to the order of Rodents or Gnawing Animals, of which squirrels, rats, mice, and rabbits are familiar examples. One of the chief characteristics of this group is the curious front teeth which are chisel-like and continue to grow as long as the owner lives; they are called incisors. The rodents have to be continually gnawing in order to keep these incisor teeth short enough for comfort.

Nearly all the rodents feed upon plant materials, and many of them are especially fond of various farm and garden crops. Some, however, as the common rat, are practically omnivorous.

The interesting family of Squirrels (Sciuridæ) includes the True Squirrels, the Marmots, and the Flying Squirrels. The True Squirrels are divided into three groups: the Tree Squirrels, of which the Gray Squirrel and Red Squirrel are familiar examples; the Rock Squirrels, of which the Chipmunk is an example, and the Ground Squirrels or Spermophiles. The Marmots include the Woodchuck and Prairie Dog.

\section{Ground SQuirRels or Spermophiles}

The Ground Squirrels or Spermophiles are now classified in the genus Citellus. They are often called Gophers, 
although this much-abused word is more properly restricted to the family of rodents commonly called Pocket Gophers. These differ greatly in structure and appearance from the ground squirrels.

The Spermophiles bear a rather striking general resemblance in habits to the Chipmunks. They are ground-loving, grain-eating squirrels, varying into more than seventy species or subspecies in the Western regions where they occur. They are known to cause an annual loss of many millions of dollars, chiefly through their injuries to grain and forage crops. They have recently been suspected of carrying germs of the deadly disease known as bubonic plague, so that they may become a menace to human life.

The Leopard Spermophile, also known as the Thirteenlined or the Striped Spermophile, is one of the most abundant and widely distributed species of ground squirrels. It occurs from Michigan and Minnesota west to the Rocky Mountains and south to Texas. It lives in burrows about two inches in diameter and not more than two feet below the soil surface. The length of these burrows varies greatly; some are mere pockets for temporary shelter, while others extend horizontally for many feet. During summer the Spermophiles come forth from their burrows in search of seeds of weeds, grains, grasses, the succulent root stems and leaves of clover, alfalfa, and other forage crops, as well as grasshoppers and other insects. All these materials serve for food. While some benefit to man is derived from the grasshoppers destroyed, it is more than counterbalanced by the injury done to grain, forage, and other crops.

Early in autumn the Leopard Ground Squirrels store up seeds and grain in their burrows. When winter comes, they fall into a hibernating sleep that lasts about five 
months, after which they awake and feed upon the stored seeds and such other food as they can find outside. During this spring season they dig up newly planted corn and other seeds. The young are generally born in April, there being six to ten in each litter.

In Wyoming, the Dakotas, and neighboring states the Gray Ground Squirrel or Franklin's Spermophile is the most abundant species. It bears a striking resemblance to the tree-loving Gray Squirrel of the Eastern states. It feeds on grain and forage crops as well as upon field mice and grasshoppers and other insects. It has also a fondness for young chickens that makes it a troublesome neighbor where poultry is raised.

In arid or semiarid regions where irrigation is practiced, various species of ground squirrels do much damage to the irrigation ditches by burrowing into them and deflecting the water.

Fortunately for man, these ground squirrels form the natural food of many predaceous mammals and birds. Such animals as coyotes, badgers, foxes, and skunks feed freely upon them. Hawks, owls, and eagles are always after them. The general destruction of these natural enemies has been an important reason for the increase in the numbers of ground squirrels.

The most practical means of destroying these pests directly is the use of poisoned food. Grain or green alfalfa is saturated with strychnine and placed in the burrows. Care is always needed, however, to avoid accidents to people, birds, and domestic animals. Precise instructions as to the best methods may be obtained upon application to the Biological Survey, United States Department of Agriculture. 


\section{Marmots}

The Marmots are represented in the United States by tivo animals of peculiar interest - the Prairie Dog and the Woodchuck. These are grouped in the squirrel family on account of their general structure, although different in appearance and habits from the typical squirrels.

The Prairie Dogs inhabit a great area west of the Mississippi River from Texas to Canada. They are especially abundant in prairie regions, where they often live in colonies of many hundred families. Each family occupies a burrow having a mound of earth at the entrance to keep out water. The details of a typical burrow are shown in the diagram on page 306 .

The Prairie Dogs feed upon a variety of grains and grasses. They are troublesome because of the food they consume, the hillocks of soil they make, and the burrows they dig. They are preyed upon by many natural enemies : among these coyotes, wolves, foxes, owls, ferrets, and rattlesnakes are the most important. In wild regions these foes serve to keep their numbers reduced, but as land is brought into cultivation the destruction of natural enemies leads to the increase of Prairie Dogs. They are readily destroyed, however, by placing poisoned grain at the mouth of their burrows or by the use of carbon bisulphide.

Nearly every farmer's boy in the easterm region of the United States is familiar with the Woodchuck or "Groundhog." This is one of the largest of the rodents, and its burrows are to be found on many farms in the hill regions of the Northeastern states. It feeds ravenously upon clovers and forage crops as well as upon beans, peas, cucumbers, and many other field and garden vegetables. In autumn 
it develops a thick layer of fat beneath the skin and retires to the burrow to hibernate.

Woodchucks are commonly trapped or shot, but the easiest way to kill them is by means of carbon bisulphide. A little of this volatile liquid is poured upon a tuft of dry moss or other absorbent material which is then rolled into the burrow. The openings are now closed by sods or soil, and the liquid will vaporize into a deadly gas heavier than air. This gas will descend to the lower portions of the burrow to destroy the animals that breathe it. If one is sure the burrow is occupied by a woodchuck, its destruction is comparatively certain.

\section{OBSERVATIONS FOR PUPILS}

\section{Ground Squirrels or SPERmophiles}

I. What kinds of ground squirrels, if any, are found in your locality ? Write a short account of what you know about the most abundant species. Follow this outline:-

Size and color.

Burrowing habits.

Feeding habits.

Crops injured.

Natural enemies.

Remedies, especially those you have seen tried.

\section{Prairie Dog and Woodchuck}

I. If either of these animals is common in your locality, write a brief account under the headings given above.

2. Read : -

American Animals, pages 151-159. The Destruction of Prairie Dogs, U. S. Biological Survey, Circular 32. 


\section{CHAPTER XXXI}

\section{The Mice and Rats}

THE family of Mice and Rats is known by the technical name Muridx. It includes a great number of species, many of which are destructive to farm crops. Among the well-known members of this group are the muskrats, meadow mice, cotton rats, wood rats, white-footed mice, and common rats.

The Short-tailed Field Mice, Meadow Mice or Voles, of the genus Microtus, are among the most destructive of all the rodents. Every farmer's boy is familiar with the appearance of these little animals. Most boys have killed many of them in

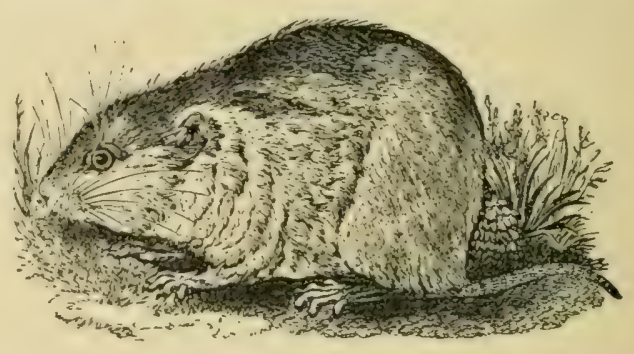

FIELD OR MEADOW MOUSE fields or meadows, and have found their rounded nests of grasses and other fibers.

There are about seventy different forms of Meadow Mice, but only a few are abundant and widely distributed. The one with which most people are familiar is called the Common Meadow Mouse, and is known technically as Microtus ponnsylianicus. This little creature is distributed over most of the United States. The typical form is found in the great region east of the Dakotas and north of a line running through Tennessee, while five 
slightly different geographical races are scattered over the rest of the country.

As soon as the snow disappears in early spring, it is easy to find the winter runways of the Common Meadow Mouse in almost any low grassland. They often cover the surface with an interlacing network that shows how inclustriously the mice have been at work beneath the snow. Should you follow up these runways carefully, you would probably come to shelter nests made of grasses which served for temporary quarters through the winter. And if you should explore late in spring or in the summer, you would often find holes leading to the underground nests in which the young are reared. The nests are likely to be lined with the soft silk from the milkweed pods or the silky seeds of cat-tail flags.

Meadow mice find their safest home along the borders of swamps or other lowlands or in neglected meadows where there is a rank growth of grass. The shelter of the grass protects them from enemies and enables them to forage far and wide. It also serves for warmth in winter and furnishes abundant material for nest building. When the snow is deep, however, the mice tunnel beneath it in all directions, seeking orchards and grain fields where food may be found.

In the matter of food the meadow mice are not very particular. They will eat almost any succulent vegetable material. They are especially fond of the swollen roots of the wild white morning glory, large numbers of which are often stored in underground piles. David E. Lantz once found a pile of these thus stored away that weighed more than a pound. The roots, stems, leaves, and seeds of most vegetable, forage, and grain crops are freely eaten. In winter they find the bark of trees and shrubs one of the 
chief sources of food, and in consequence they often do great damage in orchards, especially those recently set. Trees of good size are girdled, while small ones may have the bark nearly all torn off the trunk. As this is done in winter under shelter of the snow, the owner may not suspect any damage until it is revealed in spring.

The Common Meadow Mouse multiplies very rapidly. The average is about four litters of young each year with

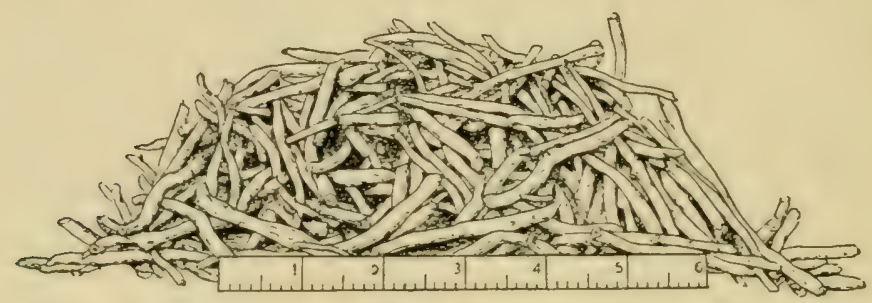

Wild Morning-glory Rools Stored by Meadow Mice

about six in each litter. It has been estimated that if there were no destruction by enemies, "a single pair and their progeny in five seasons would amount to nearly $\mathrm{I}, 000,000$ individuals." This of course does not happen because many are killed in various ways, but the estimate shows how rapidly these pests multiply under favorable conditions. It also indicates the necessity of providing as many natural checks upon their increase as possible.

In the great prairie regions of the Middle West the Prairie Mouse is abundant and destructive to a great variety of crops. It is distinguished from the Common Meadow Mouse chiefly by its shorter tail, which is not much longer than the hind foot.

The Prairie Mouse is most likely to develop in neglected fields and meadows, from which it scatters into surrounding localities. In range pastures that are not closely grazed, these mice are likely to develop in grassy tufts 
neglected by the stock. In orchards that are allowed to grow up to weeds and grasses, they are also likely to develop in such abundance as to injure the trees seriously by gnawing the bark. They are often destructive to young trees in nurseries, especially where clean culture is not given.

The rate of reproduction of the Prairie Mouse is slightly less than that of the Common Meadow Mouse, there being fewer young in each litter. The climatic conditions as to drought in sum-

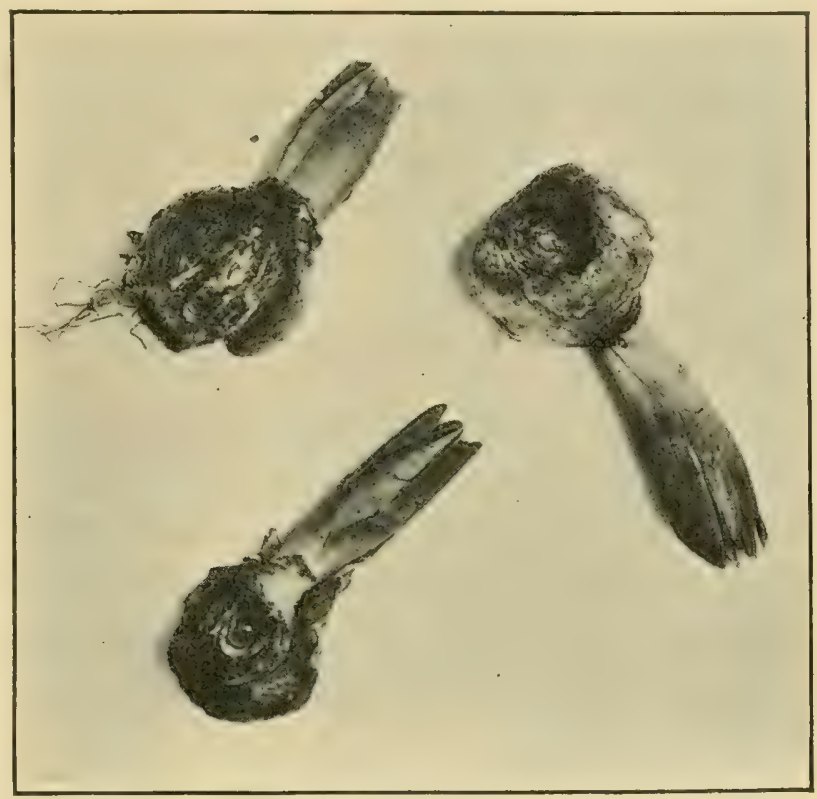

Hyacinth Bulbs eaten by Pine Mice mer and cold in winter, and the less general presence of sheltering materials, also tend to check its increase. But it often becomes far too abundant and destructive.

The runways of the Prairie Mouse and the Common Meadow Mouse are generally made above the soil surface, though commonly beneath the shelter of overhanging grasses or other vegetation. This is an easy way to distinguish them from the nearly related Pine Mouse, which makes its molelike runways through the soil itself.

This Pine Mouse in the typical form or that of a closely allied geographical race, is distributed over most parts of the United States. It makes its home in woodlands rather 
than in open fields, but it habitually invades the latter in search of food. Its journeys are made just beneath the surface of loose soil, in a manner very similar to that of the true mole, for which these mice are frequently mistaken. They feed upon a great variety of roots, tubers, and bulbs, often destroying crops in such a way that the injury is not suspected until long afterward. They seem especially fond of the tuberous roots of wild violets which are often stored up in piles in underground galleries.

\section{Natural Enemies}

Under natural conditions the rapid development of meadow mice is counterbalanced by the fact that they furnish a large part of the food of many carnivorous mammals and raptorial birds. Next to insects, mice are the most important item in the food of skunks. They form the principal food of weasels and a large part of the food of badgers and foxes.

There is little doubt, however, that the raptorial bircls are the principal natural enemies of the voles. Hawks and owls of many kinds find in these short-tailed mice their most important food. This is especially true of the Marsh Hawk and the so-called Buzzard Hawks of the genus Buteo. The latter include the Red-tailed, Red-shouldered, and Broad-winged Hawks. These are a comparatively large and heavy species that find field mice an easy prey. The Biological Survey found three hundred and fifty of these mice among the stomach contents of two hundred and twenty-eight Red-tailed Hawks.

In comparison with their number, the owls seem even more useful as mice destroyers than the hawks. These birds are abroad at night when the meadow mice are most 
active. They are able to fly noiselessly over fields and through woods and to gather their prey quickly in their hooked talons. Practically all the owls feed largely upon field mice, and several of them, notably the Screech Owl and the Long-eared Owl, find in them their chief source of food.

It has often happened that in certain regions the natural enemies of the voles have been so persecuted as to become scarce. When the checks upon their increase are thus removed, the voles multiply with alarming rapidity and become exceedingly destructive. When this occurs, the hawks and owls from surrounding regions are attracted to the infested locality, where they remain to feast upon the mice. These raptorial birds are thus like a standing army that nature moves from place to place to subdue insurrections. It is very foolish for man to wage war upon this army; he often has occasion to regret such persecution.

Various other birds are also useful as destroyers of meadow mice. Crows, ravens, and magpies feed upon them, especially the young mice. Shrikes destroy great numbers. Herons, bitterns, cranes, and gulls also feed upon them.

\section{Remedial Measures}

The ways in which farmers may aid in keeping meadow mice below the danger line are many. One of the most effective is by protecting the natural enemies of the voles. Another is that of clean culture of the places where the mice breed and the tillage of infested fields. Much help can also be obtained from cats and dogs that are good mousers and from close grazing by the larger domestic animals.

The chief means of direct destruction of the meadow mice are traps and poisons. The so-called guillotine traps 
made of coiled wire are useful if placed in the runways, either baited or unbaited, but they require constant attention. A single hawk left in peace is likely to do the work of many traps. Poisons may also be employed, but these should be used by persons of mature judgment on account of the danger of injury to children, domestic animals, and friendly birds. Specific instructions as to the best poisons and their use may be obtained from the Biological Survey, Washington, D.C. In some states the use of poisoned baits is prohibited by law.

The injury done by meadow mice to trunks of trees may generally be prevented by protecting the trunk with a wrapping of wire screening or some other tree protector. In many states wood veneer protectors are used to prevent injury by "sun scald" as well as mice. There is much evidence, also, to indicate that a simple application of the lime-sulphur wash used against the San José scale is an efficient protection. Tramping down the snow next the trees also saves them from injury, but this is not always practicable.

\section{White-footed Mice}

There are many species and varieties of the Whitefooted Mouse, which

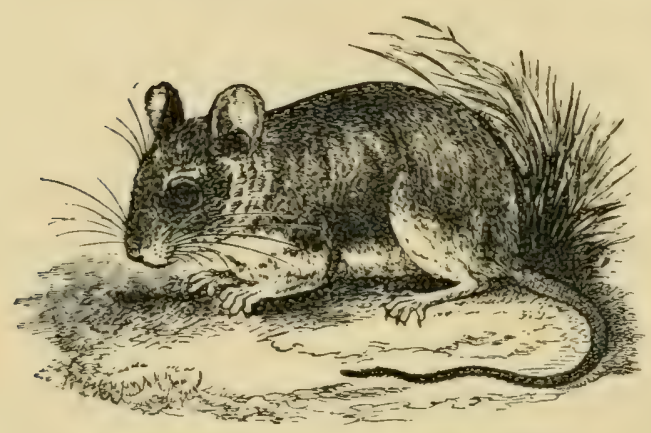

WHITE-FOOTEL OR DEER MOUSE perhaps is the most beautiful member of the family. They are all alike in having the lower parts of the body as well as the legs and feet of a white color that contrasts strikingly with 
the gray above. They live in woods and fields, making their nests in logs, hollow trees, sheds, boxes, and almost every other available place. On the Western plains they often nest in the bleaching buffalo skulls. They are not so distinctly injurious as are the meadow mice, though they often become locally troublesome.

\section{The Rats}

There is little need to direct attention to the common Brown Rat, doubtless the most destructive species of rodent in the United States. It is so because of its large size, its omnivorous feeding habits, its rapid multiplica-

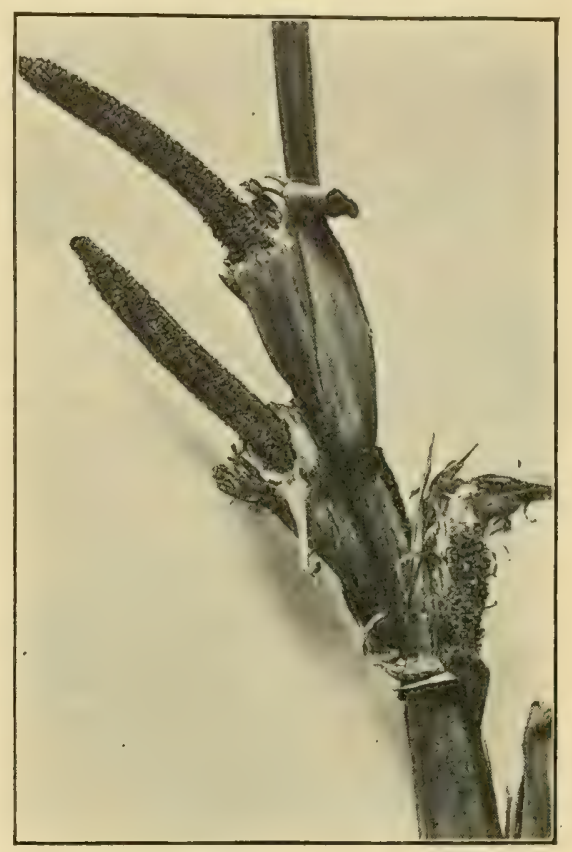

CORNSTALK RUINED BY BRUWN RATS tion, and its ability to penetrate through most obstacles. The young mature in six months, and three or four

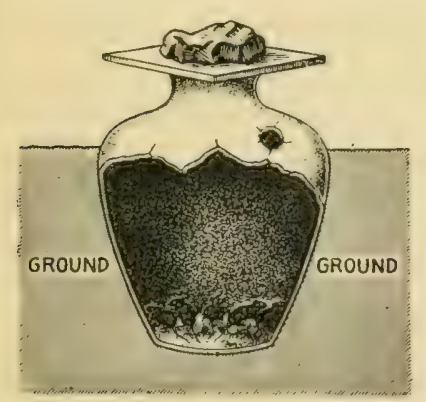

RAT TRAP USED IN BURMA litters are born a year, each litter consisting of from six to a dozen.

Rats are destructive in fields, gardens, barns, cellars, storage sheds, and houses. They feed on all sorts of vegetable and animal products, dead or alive. They carry germs of diseases, and are altogether most pestiferous creatures. War should be waged upon them in every practicable way, and buildings should be 
so concreted in cellar and basement as to prevent their entrance.

Many good traps for rats are now available. The socalled guillotine trap is perhaps the best. It is on sale in various forms in hardware stores. Each trap should be thoroughly scalded after use, in order to catch new

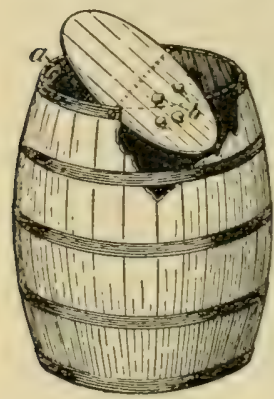

BARREL TRAP FOR RATS victims. Two ingenious forms of rat traps are shown in the accompanying pictures. The form used in Burma is a large earthenware vessel closed at the top by a board held in place by a heavy stone. The rats go in the small hole shown, and are unable to get out. Rice or other bait is put in the bottom of the jar. The barrel trap is readily understood from the picture: the bait is fastened in place at $b$; a cleat is nailed on at $a$ to hold the hinged top from going down on that side.

\section{OBSERVATIONS FOR PUPILS}

\section{MEADOW MICE}

I. Observe the runways of these mice, especially in early spring. Do you find any holes that go deeper in the ground ?

2. Look for trees and shrubs in which the bark has been gnawed off by meadow mice. Make a list of the kinds of trees and shrubs.

3. What methods of preventing damage by these pests have you known to be tried?

Read:

Meadow Mice in Relation to Agriculture, Yearbook Reprint 388.

\section{RATS.AND MICE}

I. How can you distinguish a rat from a mouse?

2. What damage have you known rats to do?

3. What ways have you tried to destroy rats?

Read:-

How to Destroy Rats, Farmers' Bulletin 369. 


\section{CHAPTER XXXII}

\section{The Rabbits, Pocket Gophers, Moles, and Shrews}

THE Rabbits probably rank next to the meadow mice as widespread destroyers in field, garden, and orchard. In the region east of the Great Plains the familiar Cottontail or Gray Rabbit is abundant. In the Northern states the Varying Hare or Northern Rabbit is found. In the West some form of the large Jack Rabbit occurs, as well as various sorts of Cottontail Rabbits. Consequently, rabbits are found over the whole United States, and do injury wherever abundant.

The damage done by Rabbits is due to their voracity and abundance. They require large amounts of food and multiply rapidly. They eat plant products exclusively, including bark, branches, buds, leaves, flowers, fruits, and seeds. Wheat, oats, barley, corn, clovers, alfalfa, and other grains and grasses are destroyed in the field. Peas, beans, cabbage, melons, and other vegetables are destroyed in the garden. Bark, twigs, shrubs, and young trees are devoured in the orchard and nursery.

With so varied a food supply, Rabbits naturally prefer the more tender and succulent products. Consequently, grain, forage, and garden crops, or fallen fruits are most commonly eaten, bark, twigs, and other less edible things being attacked chiefly in winter or in seasons of drought. The chief injury to orchard trees occurs in winter, when the bark is stripped off in a characteristic manner.

In the Western alfalfa fields Rabbits are often very 
destructive, congregating in large numbers in isolated fields and ruining the crop. In the great melon-growing regions they often cause the loss of crops by destroying young cantaloupe and watermelon plants, and in gardens everywhere they are especially destructive to peas and cabbage. The greatest damage in orchards is likely to be done to comparatively young trees, although in many applegrowing regions Rabbits are recognized as a pest always to be guarded against.

The strong hind feet are the only weapons of offense with which the rabbits are provided, but their structure, habits, and instincts enable them to escape to a large extent the attacks of their many enemies. With keen eyes so set in the head as to include a large field of vision, with large ears to detect the slightest sound, with a coloring that makes them almost invisible amid their natural surroundings, accompanied by an instinct to keep quiet most of the time, and with long legs adapted to rapid running, rabbits are well equipped in their struggle for life. Fortunately for mankind, however, many of their natural enemies are able to penetrate their disguises or overtake them as they run, so that rabbits furnish food for a considerable number of mammals and birds. Wolves, foxes, wild cats, badgers, weasels, and other carnivorous mammals live largely upon rabbits, while practically all the larger hawks and owls prey freely upon them. In wild regions these various natural enemies serve an important purpose in keeping a balance in rabbit life, but in cultivated regions such enemies often become so scarce as to be less important. As people learn the real value of certain hawks and owls as destroyers of rabbits, mice, and other mammals, they will probably learn to discriminate between friends and foes among birds of prey. 
Fortunately, rabbits are good for food, and in most regions hunting is the chief means of keeping them in check. In localities where jack rabbits are very abundant, many people sometimes combine to make a "rabbit drive" in which practically all the rabbits for miles around are driven into a wire fence inclosure where they are killed by the thousand.

Fortunately, also, rabbits are easily trapped. Most country boys have caught them in the figure-four traps. The Wellhouse trap is an improvement upon this and is readily made by following the directions at the end of this chapter. In large orchards two or
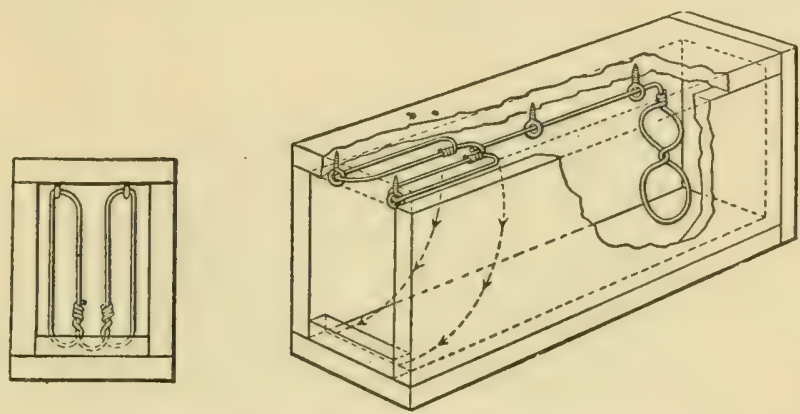

Details of Wellhouse Rabbit Trap three such traps to each acre of trees will keep the rabbits in check so that little or no damage will be done by them.

Rabbits are also destroyed by poisons, but this method should only be used by men who will see that there is no possibility of harm to children, domestic animals, or useful birds. Injuries to trees are prevented by guards of wire screening placed around the trunk. Various washes are also helpful in preventing damage to trees. One of the best of these is the lime-sulphur wash used to destroy the San José scale. A liberal spraying or brushing of the bark with this late in autumn is a protection for the winter. 


\section{Pocket Gophers}

The Pocket Gophers of the family Geomyidxe form one of the most vexatious groups of rodents. They are rather small molelike creatures with a marvelous ability to dig their way through loose soil. They live in underground burrows and feed upon the roots of trees, vegetables, and forage crops, as well as the leares of many plants. They are especially destructive to potatoes and in alfalfa fields.

The various species of Pocket Gophers found in the

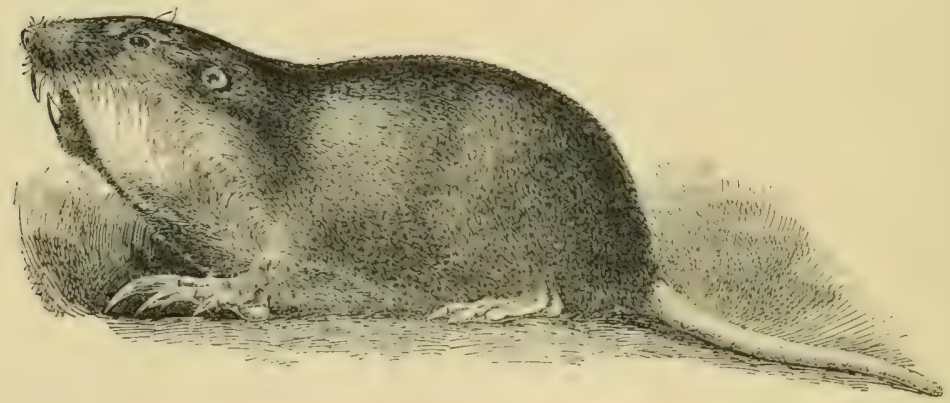

GEORgIA GOPHER

United States occur chiefly in the region west of the Mississippi River, though one is found in Georgia, Alabama, and Florida, and another in Wisconsin and Illinois. The Prairie Gopher is one of the most destructive species, as it inhabits the fertile region of the Mississippi Valley. The Plains Pocket Gopher occurs in more arid regions west, and the Gray Pocket Gopher is even more widely distributed over both prairies and plains.

The structure of the Pocket Gophers admirably adapts them to their underground life. The bodies are thickly clothed with fine hair that repels moisture and earth; the heads are pointed, the eyes and ears are small, the front feet are especially adapted to digging, and the tail is so 
sensitive that it is used as an organ of touch, when the gopher runs backward through the burrows - a habit that saves much trouble in turning round. Among the most notable points of structure are the remarkable cheek pouches that open externally.

As these gophers make their horizontal burrows, they get rid of the soil by making holes to the surface every few feet through which the loose earth is pushed out to form a little mound. The hole to the mound is finally filled up and another made farther along. In meadows and fields of forage crops these mounds sometimes make it necessary to run the mowing machines several inches above the surface of the soil, thereby preventing the harvesting of much of the crop. This is one of the most troublesome effects of the work of gophers.

The Pocket Gophers work so constantly underground that they have comparatively few natural enemies. They come to the surface oftener by night than by day, so that the owls catch more than the hawks. Other enemies are weasels, and bull or gopher snakes. Each of these enter the burrows and follow along till they find their victims.

Fortunately, the Gophers can be rather easily killed by the use of poisons without much danger to other animals. By punching a hole down to the burrow, with an old spade handle having a pointed metallic tip, one can make an opening through which small pellets of poisoned food can be inserted in the main runways, where there will be little danger of their being eaten by other animals. Such pellets should nct be placed near the mouth of a burrow, because of the danger of its being exposed where some other animal might get it. Strychnine is the poison most commonly used, and the prepared poison pellets are on sale in many drug stores. Great care is, of course, necessary in han- 
dling this deadly poison; special pains should always be taken that none of the poisoned materials be left within the reach of children.

These pests may be caught in traps placed in the burrows. Various forms of traps for this purpose are now upon the market. Gophers may also be killed by the use of carbon bisulphide, a volatile liquid that rapidly vaporizes when placed in the burrow. The vapor is a deadly poison and soon kills any animal that breathes it. It is also inflammable, and no fire must be brought near it.

\section{MOLES AND SHREwS}

There is a small order of mammals called the Insectivora or Insect-eaters. It includes the Moles and Shrews. These animals live mostly in underground burrows and are seldom seen except when turned over by accident. The burrows of Moles are familiar to many people, though doubtless the burrows of Pine Mice are often mistaken for them. Moles feed largely upon earthworms and underground insects, but are also often troublesome when they make their runways through lawns and gardens.

In the great order Carnivora or Flesh-eaters are found many of the large wild mammals, such as bears, wolves, coyotes, foxes, and badgers, as well as a number of smaller ones, such as weasels and ferrets. Many of these are efficient checks upon destructive rodents, but there is comparatively little help to be expected from them in thickly settled regions.

\section{Making the Wellhouse Trap}

The following directions for making this excellent rabbit trap are given by David E. Lantz:-- 
"The trap is a box made of 6-inch fencing boards, old ones being preferred. The box is about $2 \mathrm{I}$ inches long, closed at the back by a board, but in front by a wire door only. The door is hung from the top and sivings inward. A cleat at the bottom prevents its opening outward. The trap is set and the wire door is kept open by a wire trigger rod, held in place by two staples fastened to the top of the box. This trigger is bent downward near the rear of the trap and formed into a loop or a figure eight. As the rabbit enters the trap and crowds into the back part, it pushes upon the loop, moves the trigger wire backward, and releases the wire door. This falls and makes the rabbit a prisoner. Bait may be used, but is not necessary, since the cottontail is constantly looking for dark places to hide from enemies or cold winds. Mr. Wellhouse uses about three traps per acre in young orchards and many among the bearing trees. They are regularly looked after by boys, and so effective have they proved that no serious losses from rabbits have occurred in his orchards.

"The materials needed for making a Wellhouse trap are: Four boards I by 6, 2 I inches long; one piece I by 6,8 inches long for the back; a short cleat for the door stop; $28 \frac{1}{2}$ inches of wire to serve for the door; 22 inches of wire for the trigger; four small staples for hanging the door and trigger ; and nails."

\section{OBSERVATIONS FOR PUPILS}

I. Write or tell a story with this title: What I know about Rabbits.

2. Read: -

The Rabbit as a Farm and Orchard Pest, Yearbook Reprint 452; The Story of Raggylug in Wild Animals I have Known. 


\section{BIBLIOGRAPHY}

Teachers or pupils may obtain the various Farmers' Bulletins and other publications of the United States Department of Agriculture referred to in connection with the Observations for Pupils free of charge on application to the Secretary of Agriculture. Each school should have a set of the recent issues of the Yearbook of the Department and of the Yearbook Reprints referred to in these pages.

A set of the bulletins of the State Experiment Station should also be on file for reference, with extra copies of such as are especially useful in connection with the subjects studied.

The following books are referred to in connection with reading for pupils. They may be purchased through any book dealer.

\section{INSECTS}

DiCKERSON: Moths and Butterfics.

HOWARD : The linsect Book.

KellogG: American Insects.

Murtfeldt And Weed: Stories of Insect Life.

Peckham: The Solitary Wasps.

WEED: Life Histories of American Insects.

WEED: Nature Biographies.

\section{FUNGI}

Duggar: Fungous Diseases of Plants.

\section{Birds and Mammals}

ECKSTORM: The Bird Book.

Forbush : Useful Birds and their Protection.

Seton: Wild Animals I have Known.

Stone And Cranr: American Animals.

IVEed AND DEARBorn: Birds in their Relations to Man. 


\section{INDEX}

Acridiidæ, 67 .

Aleyrodes, 273.

Ambush bugs, I67.

Andrenidæ, 203.

Anthracnose, bean, 255 .

cotton, 256 .

raspberiry, 256 .

Ants, I69, I 73 . and aphides, 92.

Aphides, 87, 95, I87.

Aphidius, I79.

Aphis, apple, 9I.

corn-root, 92.

cotton, 90 .

dock, 9I.

European grain, 89.

melon, 9I.

orange, 9I.

spring-grain, 87 .

Aphis lions, I7I.

Apidæ, 203.

Apina, 203.

Apple blossom, I95, 2 Iо.

bitter rot, 246.

maggot, I 25.

scab, 245 .

of Peru, 4I.

Army worm, I07, I88.

Ascomycetes, 242.

Ascospore fungi, 242.

Asilidæ, I66.

Aspen, 25.

Assassin bugs, I68.

Asters, wild, 20, 23.

Bacillus amylivorus, 259.

Bacteria, nitrifying, 275 .

nitrogen-gathering, 276 .

symbiotic, 278 .
Bacterial diseases, 259, 273 .

Bacteriosis, bean, 263 .

melon, 263 .

Bark lice, 82, 95 .

Barley, mouse, 15 .

wild, I 5 .

Barnyard grass, 33 .

Bean blight, 263.

Bees, 203.

Beetle, asparagus, 136 .

Colorado potato, 135 .

cucumber, I37.

May, I3I, I47.

Beetles, I3I.

click, I34.

flea, I39.

ground, I64.

ladybird, I65.

Lamellicorn, I32.

leaf, I 35 .

long-horn, I 40.

predaceous, I64.

snapping, I 34 .

tiger, I64.

Beggar ticks, I9.

Bermuda grass, $6 \mathrm{I}$.

Billbugs, I 43 .

Bindweed, black, 42 .

hedge, 4I.

Birch, gray, 25 .

Bird's-eye rot, 256 .

Bitter rot, 246.

Blackbird, Brewer, 300 .

crow, 300.

redwinged, 300 .

Black knot, 242, 257 .

Black rot, $25 \mathrm{r}$.

Blattidx, 70.

Bluebird, 298. 
Blue-grass, flat-stemmed, I4.

Bobolink, 293.

Bollworm, i i I.

Bombycine moths, IO2, I2O.

Borer, apple-tree, I40.

locust, I40.

Bottle-grass, 32.

Bouncing Bet, Io.

Bracken, 24 .

Brake fern, 24.

Brown rot, 247.

Buckwheat, wild, 42 .

Buffalo bur, 39.

Bumblebees, 204.

Burdock, 7 .

Bur marigold, I 9 .

Butter-and-eggs, Io, Ir.

Buttercups, 24.

Butterflies, 97, II9.

Butterfly, Asterias, 97.

black swallowtail, 97 .

cresphontes, 98.

mourning cloak, 98 .

Cabbage butterfly, 97, I86.

clubroot, 257 .

maggot, I 27.

rot, 26I.

worm, 97, I86.

Carabidæ, I64.

Caraway, ir.

Carnivora, 320.

Carrot, small, $2 \mathrm{I}$. wild, 20.

Catbird, 299.

Caterpillar fungi, 272.

Cecidomyiidæ, I 23.

Cedar, red, 25.

Cerambycidæ, 140.

Chalcid flies, I52, I82.

Charlock, 33, 47 .

Cheat grass, 45 .

Cherry, black, 28 .

choke, 28 .

flower, 194.

Chess, 45 .
| Chickweed, mouse-ear, 34.

smooth, 34 .

Chicory, II.

Chinch bug, 75 . fungus, 76 .

Chondrilla, I9.

Chrospidx, I 7 I.

Chrysomelidæ, I35.

Cicada, dog-day, 78 . periodical, 78 .

Cicadidæ, 77.

Cicindelidæ, 164 .

Cinquefoil, common, 23 .

Norwegian, 23.

silvery, 23 .

Clotbur, 38 .

Clover-seed midge, I 24.

Clubroot, cabbage, 257 .

Coccidæ, 82 .

Cockle, 49.

Cocklebur, 38.

Cockroaches, 70.

Codling moth, II3.

Coleoptera, I3I.

Cone-flower, I9.

Corn cockle, 49.

rootworm, northern, 137 . southern, I 38 .

rust, 238 .

smut, 228, 230.

stalk-borer, II 2 .

worm, III.

Cotton boll weevil, I44, I48.

rot, 203.

wilt, $25 \mathrm{I}$.

Couch-grass, I4.

Cowbane, spotted, 27.

Crab-grass, 33.

Crane flies, I 25.

Crazy weed, 26.

Cricket, black, 69 .

mole, 70.

tree, 70 .

Cross-fertilized flowers, I99.

Crow, 293.

Crown gall, 26r. 
Currant worm, I 50, I53.

Cutworms, I09.

Cynipidæ, $\mathbf{I}_{52}$.

Cypress spurge, io.

Daisy, oxeye, I6.

Dandelion, 3 .

Day lily, Io.

Diptera, I22, I88, 207.

Dock, bitter, 8.

broad-leaved, 8, 59 . curled, 8.

sour, 8.

yellow, 8 .

Dodder, 53.

Dragon flies, I 70.

Elaters, I34.

Elecampane, Io.

Entomophthorex, 27I.

Evening primrose, 9.

False flax, 49 .

Fern, brake, 24 . cinnamon, 24 .

flowering, 24 . interrupted, 24. sensitive, 24 .

Fertilization of flowers, I94.

Finger-grass, 33.

Fireweed, 9.

Five-fingers, 23.

Flea-banes, I9.

Flea beetles, I 39 .

Flies, two-winged, I22, I88, 207.

Fly-away-grass, 32.

Foxtail, green, 32 .

yellow, 32 .

Fruit maggots, I 25.

Fungicides, 267.

Gallflies, I 52 .

Gallfly, blackberry, I 52 .

Gall gnats, I 23.

Gill-over-the-ground, 44 .

Goldenrods, 23, $6 \mathrm{I}$.

Goosefoot, 35 .
Gophers, 307.

Georgia, 324 .

pocket, 324 .

Grackle, bronzed, 300.

purple, 300 .

Grape mildew, 223.

Grape rot, black, $25 \mathrm{I}$. brown 223.

Grape slug, I5 I.

Grasshopper, meadow, 69, 72 . structure of, 65 .

Ground cherries, 40.

Ground squirrels, 307, 31 2.

Gryllidx, 69.

Gypsy moth, ro3.

Hardhack, I 3, 25, 62.

Harlequin cabbage bug, 77, 94 .

Harvest fly, 78 .

Hawk, marsh, 302. moths, IOI, 208. sparrow, 202.

Hawkweed, orange, I7.

Hemiptera, 73.

Hessian fly, I23, I 29.

Honeybees, 206.

Horse nettle, 39 .

Horse-radish, II.

Horseweed, 37.

Husk tomato, 40.

Hymenoptera, I49, I69.

Hyperparasites, I80.

Ichneumon flies, I74.

Insecticides, 155 .

Insectivora, 326.

Insect-killing fungi, $27 \mathrm{I}$.

Ironweed, 20.

Jamestown lily, 4I. weed, 4I.

Jimson weed, 4I.

Joe-pye weed, 20.

Johnson-grass, I4, 6r.

Jumping plant lice, 82 .

Juniper, low, 25. 
Kingbird, 30r.

Lacewinged flies, I7I.

Ladybird, Australian, I66.

Lamb-kill, 28 .

Lamb's-quarters, 35, 43 .

Larkspur, dwarf, 27.

purple, 27.

Wyoming, 27 .

Laurel, mountain, 28 . sheep, 28.

Leaf hoppers, 78, 94 . apple-tree, $8 \mathrm{r}$. grape, 80 . rose, $8 \mathrm{I}$.

Leaf miners, II 5 , I29, I3O. rollers, II 5 .

Leaf roller, rose, II 5 .

Lemon rot, 224.

Lepidoptera, 96, 207.

Lettuce, prickly, 6 .

Lima bean mildew, 223 .

Live-forever, ro.

Loco weed, stemless, 26. woolly, 26 .

Locust, black, 25 . honey, 25. yellow, 25 .

Locustidæ, 69 .

Locusts, long-horned, 69. short-horned, 67 .

Mad apple, 4I.

Mantids, 7I, I I I.

Marmots, 3 Io.

Meadow lark, 292.

Mice, field, 3I 2.

meadow, 3I 2, 320 .

pine, 3I5.

prairie, 3I4.

white-footed, $3 \mathrm{I} 8$.

Microgaster flies, I 77 .

Microtus pennsylvanicus, 3 I 2 .

Mildew, bean, 254 .

cherry, 254 .

gooseberry, 254 .
Mildew, grape, 223, 254 .

Lima bean, 222.

melon, 223 .

onion, 223.

Mildews, downy, 2r9. powdery, 252, 258 .

Milkweed, 23.

Molds, 215 .

Morning glory, wild, 4I.

Moth, brown-tail, I06, I2 I.

Cecropia, I02.

Luna, IO2.

Polyphemus, I02.

Promethea, Io3.

Muridx, 3 I 2.

Mushrooms, 215, 224.

Mustard, black, 33, 48.

English, 47.

hedge, 48 .

tall, 48 .

tumbling, 48 .

wild, 33,47 .

Noctuidæ, I07.

Oak twig pruner, I4I.

Oats, wild, 4, 7 . smut, 226, 229.

Old-witch-grass, 32 .

Onion maggot, I 28.

mildew, 223. smut, 229.

Orange-dog caterpillars, 98 . fruit fly, I 24 . maggot, I 26.

Orthoptera, 65 .

Owlet moths, I07.

Papilionina, 97.

Parasite, plant-louse, $\mathbf{7} 78$.

primary, I8o. secondary, I8o. tertiary, $\mathrm{i} 80$.

Parasitic fungi, 218.

Peach, leaf curl, 243. twig borer, I 16 . 
Peach, worm, iा6.

Pear blight, 259, 263. leaf blight, 249 .

midge, I 24 . scab, 245 .

Pelecinus fly, I85.

Pentatomidæ, I66.

Peppergrass, 33 .

Phøebe, 30r.

Phycomycetes, 2 I9.

Phymatidæ, I67.

Physalis, 40.

Pigeon-grass, 32.

Pigweed, common, 36 . white, 35,43 .

Pine sawyer, I4I.

Plantain, broad-leaved, 8. large-bracted, $2 \mathrm{I}$. narrow-leaved, 8, 22. western, $2 I$.

Plum, curculio, I4I, I46. pockets, 244. pollination of, 200.

Pocket gophers, 324 .

Poison hemlock, 27. ivy, 27 .

Pollination of flowers, I94.

Poppy, corn, 50. field, 50 .

Potato blight, early, 255 . late, 219. scab, 254 .

Prairie dog, 3Io.

Predaceous, beetles, I64, I 72 . bugs, $167,172$.

flies, I68, I72.

insects, $\mathrm{I} 63$.

Proctotrypid flies, 185 .

Psyllidæ, 82.

Puccinia coronata, 238.

pruni, 239.

rubigo-vera, 237.

Sorghi, 238.

Purslane, 35,43 .

Quack-grass, I4, 3I, 6r.
Rabbit, cottontail, $32 \mathrm{I}$. jack, $32 \mathrm{I}$. northern, $32 \mathrm{I}$.

Radish, maggot, I 27 . wild, 33 .

Ragweed, 37. giant, 37 .

Railroad worm, I 25 .

Rat, brown, 3I9.

Rattlebox, 27.

Rattleweed, 27.

Redroot, 36 .

Reduviidx, I68.

Rib-grass, 22.

Ribwort, 22.

Robber flies, r.68.

Robin, 294, 298.

Roman wormwood, 37.

Root maggots, I 26, I30.

Rose, bug, I33. chafer, I33, I48.

Rust, apple, 238. asparagus, 23r. cedar, 238. clover, 234. corn, 238. hollyhock, 240. oats, 238 . plum, 239. raspberry, 239. rose, 235 . wheat siem, 235 . leaf, 237 .

Rusts, 23I, 240.

St. Johnsworts, 23.

Salsify, II.

Sassafras, 25.

Savin, 25.

Sawflies, I49.

Sawfly, willow, 150.

Scale, black, 85 . cottony maple, 83 . insects, 82 . San José, 86.

Seventeen-year locust, 78 . 
Sheep sorrel, 22.

Shepherd's purse, 34 .

Smut fungi, 226.

Sneezeweed, 27.

Soapwort, Io.

Soldier bugs, 167 .

Sorrel, field, 22. sheep, 22.

Sparrow, chipping, 296.

English, 297.

Sparrows, 293, 296.

Spanish needles, r9.

Sphingidæ, Ioo.

Sphinx moths, roo, I19, 208.

Pandorus, IоI.

Squash, blossoms, I96,'2 II .

bug, 73,94 .

Squirrel-tail grass, I5.

Stick-tights, I 9 .

Strawberry, barren, 23.

blossoms, I98, $21 \mathrm{I}$.

leaf spot, 250 .

wild, 23.

Sumach, dwarf, 29.

mountain, 29.

poison, 29 .

smooth, 29.

staghorn, 29.

velvet, 29.

Sundrops, Io.

Sunflower, wild, r9.

Superparasitism, I8r.

Sweet clover, II. fern, I3, 25.

Syrphidæ, I69.

Syrphus flies, I69.

Tachina flies, I88.

Tachina fly, large-horned, Igo.

Tachinidx, I 88 .

Tansy, Ir.

Teasel, Iо.

Tent caterpillars, 103, I86.

Tenthredinidæ, I49.

Thistle, Canada, I8.

pasture, I7.
Thistle, Russian, I 50.

Thorn apple, 4I.

Tickle-grass, 15 .

Tineina, I 16.

Tipulidæ, I26.

Toadflax, I I.

Toadstools, 2 I 5 .

Tomato worms, IoI.

Tomato, strawberry, 40.

Tomato fruit worm, III.

Tortricina, I I 5 .

Tree hoppers, 79 .

Trumpet miner, apple-leaf, i I6.

Tumbleweed, 36 .

Russian, 50.

Turnip maggot, I 27 .

Uredinales, 23I.

Ustiliginales, 226.

Varying hare, 32I.

Vegetable oyster, II.

Verbena, wild, 20.

Vervain, 20.

Vespidæ, I 70.

Voles, 312.

Walking sticks, 7 7 , 72 .

Wasps, social, I 70.

solitary, I 70.

Webworm, fall, 105, т86.

Wheat jointworm, ${ }_{53}$.

midge, I 24.

Wheel bug, I6ع.

White fly fungi, 273 .

White grub, I3I.

White-tops, I9.

Whiteweed, 16.

Willow-herb, 9 .

Wire-grass, I4.

Wireworms, I34.

Witch-grass, I4, $3 \mathrm{I}$.

Woodchuck, 3 IO.

Yarrow, II. 
ADVERTISEMENTS 



\section{Science}

Austin's Clinical Chemistry. A manual of applied physiological chemistry. \$1.75.

Benton's Guide to General Chemistry. A manual for the laboratory. 35 cents. Boyer's Laboratory Manual in Biology. Treats of both animals and plants. So cts. Boynton, Morse and Watson's Laboratory Manual in Chemistry. 50 cents. Burrage and Bailey's School Sanitation and Decoration. 1llustrated. 1.50 .

Cheston, Gibson and Timmerman's Physics. Theoretical and descriptive. \$1.25. Chute's Physical Laboratory Manual. Revised edition. Illustrated. So cents. Chute's Practical Physics. For schools and colleges. \$1.r2.

Clark's Methods in Microscopy. Detailed descriptions of successful methods. $\$ 1.60$. Coit's Chemical Arithmetic. With a short system of analysis. 50 cents.

Coleman's Elements of Physics. For secondary schools. \$1.25.

Colton's Physiology : Practical and Descriptive. Illustrated. \$1.40.

Colton's Physiology: Briefer Course. For earlier years in high schools. Illustrated. 90 cents.

Colton's Practical Physiology. A laboratory course. 6o cents.

Colton's Zoology: Descriptive and Experimental. Illustrated. \$1.50. Part I, Descriptive, $\$$ I.00. Part II, Experimental, 6o cents.

Fisher and Patterson's Elements of Physics. Experimental and descriptive. 60 cents.

Grabfield and Burns's Chemical Problems. For review and drill. Paper, 25 cts. Hyatt's Insecta. A practical manual for students and teachers. Illustrated. \$1.25. Newell's Descriptive Chemistry. A full exposition of modern inorganic chemistry. Illustrated. \$1.20. Part I, Without experiments. \$1.00. Part II, Experiments. 40 cents.

Newell's Experimental Chemistry. A modern course for high schools and colleges. \$1.Io.

Orndorff's Laboratory Manual in Organic Chemistry. Boards. 35 cents.

Palmer's Questions and Problems in Chemistry. 20 cents.

Pepoon, Mitchell and Maxwell's Plant Life. A laboratory guide. 50 cents.

Remsen's Organic Chemistry: \$1.20.

Roberts's Stereo-Chemistry. Its development and present aspects. \$1.00.

Sanford's Experimental Psychology. Part I. Sensation and perception. \$.50. Schoch's Experiments and Discussions in Chemistry. 50 cents.

Shaler's First Book in Geology. Cloth, 60 cents. Boards, 45 cents.

Shepard's Inorganic Chemistry. Descriptive and qualitative. SI.I2.

Shepard's Briefer Course in Chemistry, with chapter on Organic Chemistry. So cts. Shepard's Laboratory Note-Book. Boards. 35 cents.

Spalding's Botany. Practical exercises in the study of plants. So cents.

Stevens's Introduction to Botany. Illustrated. \$1.25. Key and Flora, 40 cents. Botany, with Key and Flora, $\$ 1.50$.

Stevens's Chemistry Note-Book. Laboratory sheets and covers. 50 cents.

Venable's Short History of Chemistry. For students and the general reader. 1.00 .

Weed and Crossman's Laboratory Guide in Zoology. Emphasises essentials. 60 cts.

Whiting's Physical Measurement. Parts I-IV, in one volume. $\$ 3.75$.

Whiting's Mathematical and Physical Tables. Paper. 50 cents.

For elementary zuorks see our list of books in Elementary Science.

D. C. HEATH \& CO., Publishers, Boston, New York, Chicago 


\section{Elementary Science}

Austin's Observation Blanks in Mineralogy. Detailed studies of 35 minerals. Boards, 88 pages. 30 cents.

Bailey's Grammar School Physics. A series of practical lessons with simple experiments that may be performed in the ordinary schoolroom. ${ }_{13} S$ pages. Illustrated. 50 cents.

Ballard's The World of Matter. Simple studies in chemistry and mineralogy; for use as a text-book or as a guide to the teacher in giving object lessons. 264 pages, Illlustrated. \$1.00.

Brown's Good Health for Girls and Boys. Physiology and hygiene for intermediate grades. 176 pages. Illustrated. 45 cents.

Clark's Practical Methods in Microscopy. Gives in detail descriptions of methods that will lead the careful worker to successful results. 233 pages. Illus. \$I.60.

Clarke's Astronomical Lantern. Intended to familiarize students with the constellations by comparing them with facsimiles on the lantern face. With seventeen slides, giving twenty-two constellations. $\$ 4.50$.

Clarke's How to Find the Stars. Accompanies the above and helps to an acquaintance with the constellations. 47 pages. Paper. 15 cents.

Colton's Elementary Physiology and Hyrgiene. For grammar grades. 3r7 pages. Illustrated. 60 cents.

Eckstorm's The Bird Book. The natural history of birds, with directions for observation and suggestions for study. 30 r pages. Illustrated. 60 cents.

Guides for Science Teaching. Teachers' aids for instruction in Natural History. I. Hyatt's About Pebbles. 26 pages. Paper. Io cts.

II. Goodale's A Few Common Plants. 6r pages. Paper。 $20 \mathrm{cts}$.

III. Hyatt's Commercial and other Sponges. Illustrated. 43 pages. Paper. $20 \mathrm{cts}$.

IV. Agassiz's First Lesson in Natural History, 1llus. 64 pages. Paper. $25 \mathrm{cts}$.

V. Hyatt's Corals and Echinoderms. Illustrated. 32 pages. Paper. $30 \mathrm{cts}$.

VI. Hyatt's Mollusca. Illustrated. 65 pages. Paper. $30 \mathrm{cts}$.

VII Hyatt's Worms and Crustacea. Illustrated. 68 pages. Paper, 30 cts.

XII. Crosby's Common Minerals and Rocks. Illustrated. 200 pages. Paper, 40 cents. Cloth, 60 cts.

XIII. Richard's First Lessons in Minerals. 50 pages. Paper. Io cts.

XIV. Bowditch's Physiology. 58 pages. Paper. 20 cts.

XV. Clapp's 36 Observation Lessons in Minerals. 80 pages. Paper, 30 cts.

XVI. Phenix's Lessons in Chemistry. 20 cts.

Pupils' Note-book to accompany No. 15. ro cts.

Rice's Science Teaching in the School. With a course of instruction in science for the lower grades. 46 pages. Paper. 25 cents.

Ricks's Natural History Object Lessons. Information on plants and their products, on animals and their uses, and gives specimen lessons. 332 pages. IIlustrated. \$1.50.

Ricks's Object Lessons and How to Give Them.

Vol. I. Gives lessons for primary grades. 200 pages. 90 cents.

Vol. II. Gives lessons for grammar and intermediate grades. 212 pages. $90 \mathrm{cts}$.

Scott's Nature Study and the Child. A manual for teachers, with outlines of lessons and courses, detalled studies of animal and plant life, and chapters on methods and the relation of nature study to expression. 6;2 pages. Illustrated. Retail price, \$ 50.

Sever's Elements of Agriculture. For grammar grades. Illustrated. I5r pages. 50 cents.

Shaler's First Book in Geology. A helpful introduction to the study of modern text-books in geography. 272 pages. Illus. Cloth, $60 \mathrm{cts}$. Boards, $45 \mathrm{cts}$.

Smith's Studies in Nature. Combınes natural history and language work. $4^{\mathrm{S}}$ pages. Paper. 15 cents.

Spear's Leaves and Flowers. An elementary botany for pupils under twelve. 103 pages. Illustrated. 25 cents.

Wright's Seaside and Wayside Nature Reader, No. 4. Elementary lessons in geology, astronomy, world life, etc. 372 pages. Illustrated. 50 cents.

See also our list of books in Science.

D. C. HEATH \& CO., Publishers, Boston, New York, Chicago 


One copy del. to Cat. Div.

$$
\text { huv } 18980
$$


LIBRARY OF CONGRESS

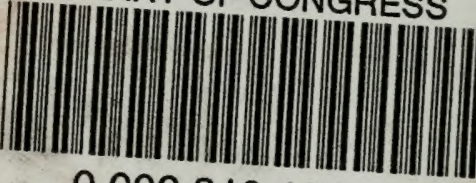
00028101661 